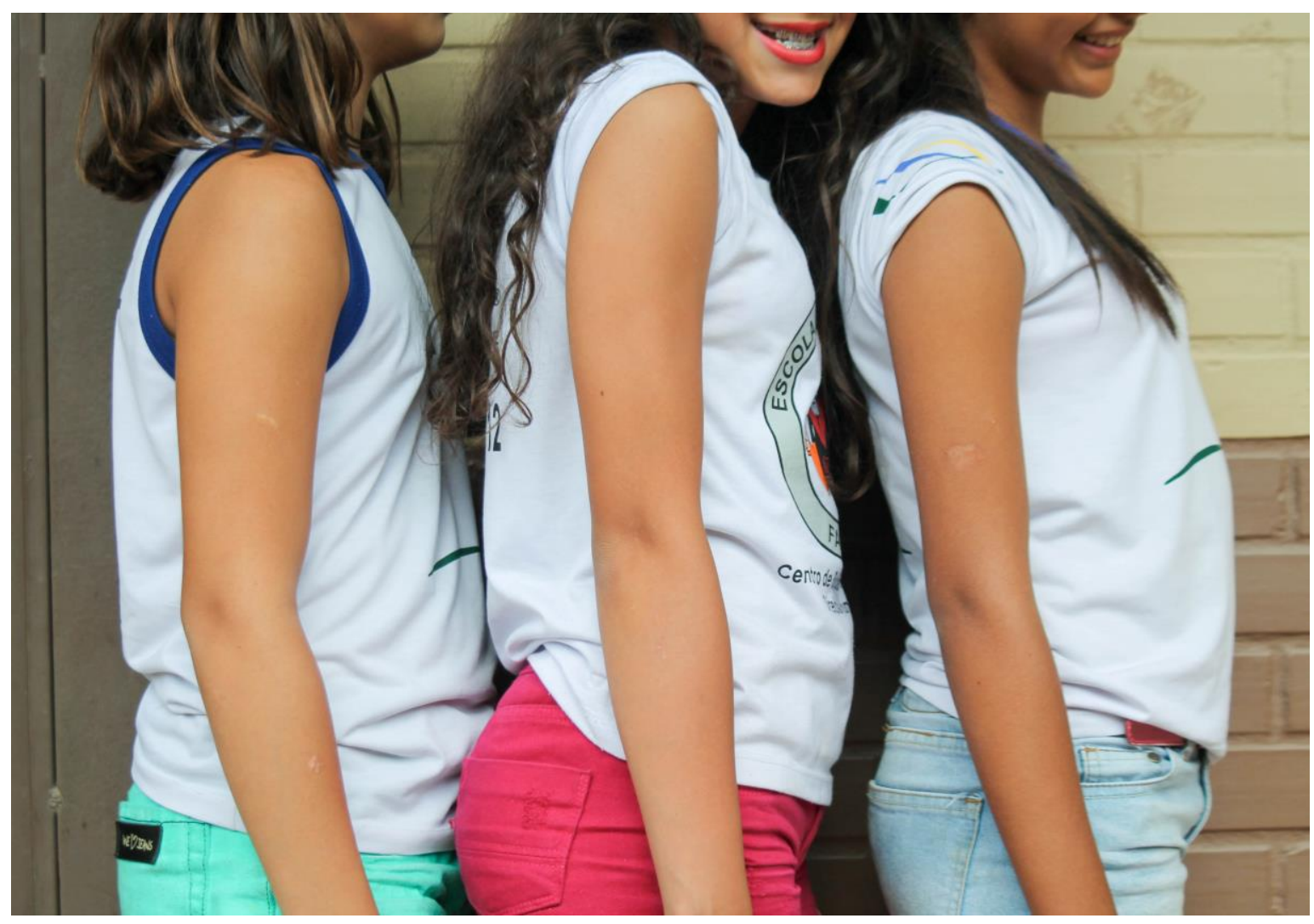




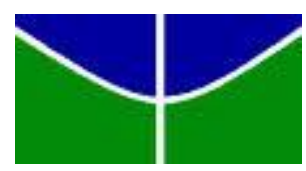

UNIVERSIDADE DE BRASÍLIA INSTITUTO DE CIÊNCIAS SOCIAIS

DEPARTAMENTO DE ANTROPOLOGIA

PROGRAMA DE PÓS-GRADUAÇÃO EM ANTROPOLOGIA SOCIAL

Natália Almeida Bezerra

QUANDO A VACINA ENTRA NA ESCOLA

Brasília, 2017 
UNIVERSIDADE DE BRASÍLIA

INSTITUTO DE CIÊNCIAS SOCIAIS

DEPARTAMENTO DE ANTROPOLOGIA

PROGRAMA DE PÓS-GRADUAÇÃO EM ANTROPOLOGIA SOCIAL

\section{QUANDO A VACINA ENTRA NA ESCOLA}

Natália Almeida Bezerra

Dissertação apresentada ao Departamento de Antropologia da Universidade de Brasília como parte dos requisitos para obtenção do título de Mestra em Antropologia Social, pela Universidade de Brasília - UnB.

Orientadora: Soraya Resende Fleischer

Brasília, 2017 


\title{
QUANDO A VACINA ENTRA NA ESCOLA
}

\author{
Natália Almeida Bezerra \\ Orientadora: Dra . Soraya Fleischer
}

Dissertação apresentada ao Departamento de Antropologia da Universidade de Brasília como parte dos requisitos para obtenção do título de Mestra em Antropologia Social, pela Universidade de Brasília - UnB.

Banca Examinadora:

Dra . Soraya Resende Fleischer (Presidente) - DAN-UnB

Dra . Mónica Lourdes Franch Gutiérrez - PPGA/UFPB

Dr $^{a}$. Rosamaria Giatti Carneiro - FCE/UnB

Dra . Silvia Guimarães (suplente) - DAN- UnB

Brasília, 20 de fevereiro de 2017. 
A Vó Maria, João, Marta, Vidinha, Das Dores, Joana, Bárbara, Fernanda, Vera, Ingrid, Henrique, Felipe e Luiz Fernando pelo amor e apoio de sempre. 


\section{AGRADECIMENTOS}

Antes de tudo, gratidão é a palavra que marcou minha trajetória. São muitas as pessoas que contribuíram para que este trabalho pudesse acontecer. Mas, anterior a elas, estava Deus, traçando cada passo e abrindo as portas que seriam necessárias.

Agradeço a minha família que é a minha base de vida, ao meu pai, os quais acreditam em mim, me incentivam a seguir quando não há força, que dividem mais alegrias que tristeza. Em especial, à casa das "sete mulheres", que foi onde eu cresci e pude aprender que a força feminina é linda e poderosa e que ter um coração bom e fé na vida é determinante para o brilho pessoal e alcance dos sonhos.

Um agradecimento especial a minha mãe, por ter dividido o campo comigo - explicarei a frente. Obrigada pelos ótimos papos, pelas ideias, pela força, pelas risadas, pelos almoços, por ser uma mãe incrível. O meu semestre de pesquisa foi muito mais colorido por ter você ao meu lado.

Ao Luiz Fernando, minha nova casa é você. Grata pela parceria e companhia nos momentos de escrita. Sei que acreditou muito nesse trabalho e que acredita em nós.

Gratidão à Soraya Fleischer, minha orientadora querida, tenho muita admiração pelo trabalho atencioso e cheio de afeto que sempre dispensou a mim e a outros colegas também. Foram muitos os diálogos, provocações teóricas, conselhos e reescritas, que hoje se fazem presentes no texto que virá e que adensaram minha postura enquanto antropóloga. Agradeço a tudo isso também, Soraya.

Grata a todos os meus colegas de mestrado e Katacumba, os quais pude conviver em alguma disciplina ou mesmo nos momentos de encontros casuais, com carinho especial para os mais chegados - Lucas Coelho, Bia Moura, Marcos Alvarenga, Cacá, Felipe Henrique, Andressa Morais e Nicholas. Foram trocas constantes de ideias, companheirismo, angústias, alegrias e apoio. Agradeço especialmente às minhas amigas do peito, Ranna Mirthes, Mariana Guimarães, Fernanda (tia e irmã), que sempre ao meu lado, me apoiaram na fase mais difícil a reta final da escrita.

Aos professores das disciplinas cursadas - Andrea Lobo, Carla Teixeira, Fabiene Gama, Antonádia Borges, Marcela Coelho, João Miguel Sautchuk, Elen Woortmann - vocês foram luz para o para o meu processo de aprendizagem e refinamento do olhar perante o 
mundo, grata. Aos servidores da secretaria, meu obrigada, pois sempre me atenderam com zelo e prontidão e obrigada também a todos os outros funcionários do departamento, lembrandome do IRIS, o qual a ajuda com as fotografias da dissertação foi fundamental.

Nesta trajetória também estão presentes as/os veteranas/os e as/os novatas/os pesquisadoras/res do meu grupo de orientação coletiva, pessoas brilhantes, diga-se de passagem - Ana Clara Damásio, Raquel Lustosa, Natália Silveira, Rosana Castro, Ângelo Daré, Gabriela Marques, Cíntia Engel. Foram as pessoas que com quem pude dialogar durante a escrita da dissertação e que me ajudaram a clarear e ordenar minhas ideias. Eu não poderia deixar de agradecer pelas contribuições, incentivos, experiências compartilhadas e leituras tão atentas dos meus escritos. Trabalhar em grupo é muito produtivo.

Agradeço ao Governo do Distrito Federal por ceder espaço em seus órgãos para o aperfeiçoamento e capacitação de servidores por meio de licenças para o estudo stricto sensu. Grata à Izabel, que tratou de todo o meu processo de afastamento, ajudando-me a resolver as pendências que apareceram. Quero lembrar também da turma da "repartição", nas pessoas de Diana, Talita, Daysy, Osmar, Martha, Tânia, dentre outras queridas/os, que me apoiaram nesse projeto. Sinto-me contemplada e feliz por ter trabalhado com vocês.

E agora, ao campo de pesquisa, meu mais especial obrigada. Dentre a escola pesquisada, as visitas ao centro de saúde, os pais e as mães, as meninas e os meninos, todos foram fundamentais e preciosos para que eu cumprisse o meu propósito de pensar e escrever sobre a vacina HPV. Minha aprendizagem e escrita são devedores destes tantos atores sociais que me acolheram. Aqui eu poderia gastar mais de uma página para listar todos que me ajudaram, que concederam entrevistas, bate-papos, imagens, cederam seu tempo a mim. Foram muitas pessoas admiráveis que encontrei no caminho, porém não posso nomeá-los. Em nome das orientadoras da escola, que mais próximo trabalhei, meu imenso agradecimento a todas/os as/os professoras/res e funcionárias/os.

Grata aos adolescentes e jovens que pude conhecer e conversar. Grata por poder voltar ao espaço escolar e redescobrir marcas em mim e no mundo que só a educação pode deixar. Um brinde a todos vocês. 
O presente trabalho é resultado de um estudo etnográfico sobre a vacinação do HPV, realizado em uma escola pública do Distrito Federal. O objetivo desta pesquisa é conhecer o mundo social que envolveu a vacina dentro da escola, a partir da construção que os atores envolvidos - profissionais da educação e da saúde, mães e pais, meninas e meninos, fizeram ou possuíam sobre a vacinação do HPV. As vacinas têm-se revelado, diria historicamente, uma fonte de prevenção, de fortalecimento do corpo. Mas como um processo apropriado, tanto pelo Estado como pelo ser humano, sofreu e sofre vários tipos de interpretações e apropriações, extrapolando o mundo biomédico e ganhando diferentes contornos sociais e culturais. Tudo isso releva diversos posicionamentos, sejam com o próprio corpo, para com/ou da família, com os poderes institucionais. Quando nos deparamos com uma vacina que chegou ao Brasil há pouco, realizada apenas em corpos femininos muito jovens, esses ainda representados por seus pais, e que recebem a dose fora de seu campo jurisdicional "natural" - as unidades médicas - mas sim, dentro de uma instituição de ensino, este contexto vacinal se torna ainda mais interessante. É sobre a trajetória da vacina HPV e seus desdobramentos que esta pesquisa se debruçou.

Palavras-chave: Antropologia, Saúde, Estado, Escola, Vacinação/HPV. 


\begin{abstract}
The present work is the result of an ethnographic study on HPV vaccination, carried out in a public school in the Federal District. The objective of this research is to know the social world that involved the vaccine within the school, from the construction that the actors involved professionals of education and health, mothers and fathers, girls and boys, did or had on this one. The vaccine has been, I would say historically, a source of prevention, of strengthening the body. But as an appropriate process, both by the State and by the human being, it suffered and undergoes various types of interpretations and appropriations, extracting the biomedical world and gaining different social and cultural contours. All of this relies on several maneuvers, be it with the body itself, towards the family, with institutional powers. When we are faced with a vaccine that has recently arrived in Brazil, carried out only on very young female bodies, those still represented by their parents, and receiving the dose outside their "natural" jurisdictional field - the medical units - but within Of an educational institution, this vaccine context becomes even more interesting. It is about the trajectory of the HPV vaccine in a school and the social world that it involved, this research looked at.
\end{abstract}

Keywords: Anthropology, Health, State, School, Vaccination / HPV. 
Quando uma ideia boa me chegava eu a prendia na minha "gaiola de prender ideias", um caderninho, na esperança de um dia transformá-la em algo. Mas a quantidade de ideias que eu colocava na gaiola de prender ideias era muito maior que minha capacidade de escrever. Elas nunca iriam se transformar sozinhas. Seriam condenadas ao esquecimento. Fiquei com dó delas. Resolvi então tirá-las da gaiola e soltá-las aos quatro ventos. Estão aí, neste livro [nesta dissertação].

Rubem Alves in Ostra Feliz Não Faz Pérola 


\begin{tabular}{|c|c|}
\hline ANVISA & Agência Nacional de Vigilância Sanitária \\
\hline BCG & Bacillus Calmette-Guérin \\
\hline CAJE & Centro de Atendimento Juvenil Especializado \\
\hline CCU & Câncer de Colo de Útero \\
\hline CODEPLAN & Companhia de Planejamento do Distrito Federal \\
\hline CONITEC & Comissão Nacional de Incorporação de tecnologia do SUS \\
\hline CRE & Coordenação Regional de Ensino \\
\hline CS & Centro de Saúde \\
\hline DF & Distrito Federal \\
\hline DSEI & Distritos Sanitários Especiais Indígenas \\
\hline DST's & Doenças Sexualmente Transmissíveis \\
\hline FDA & Federal Drug Administration \\
\hline GDF & Governo do Distrito Federal \\
\hline HPV & PapilomaVírus Humano \\
\hline HUB & Hospital Universitário de Brasília \\
\hline INCA & Instituto Nacional de Câncer \\
\hline IRIS & Laboratório de Imagem e Registro de Interações Sociais \\
\hline MEC & Ministério da Educação \\
\hline MG & Minas Gerais \\
\hline MPF & Ministério Público Federal \\
\hline MS & Ministério da Saúde \\
\hline OMS & Organização Mundial de Saúde \\
\hline OPAS & Organização Panamericana de Saúde \\
\hline PBF & Programa Bolsa Família \\
\hline PCN & Parâmetros Curriculares Nacionais \\
\hline PDAP & Pesquisa Distrital por Amostra de Domicílios \\
\hline PNI & Programa Nacional de Imunização \\
\hline PNPS & Política Nacional de Promoção em Saúde \\
\hline
\end{tabular}


PSE Programa Saúde na Escola

RCBP Registros de Câncer de Base Populacional

SECRIA Secretaria de Estado de Políticas para Crianças, Adolescentes e Juventude

SEDF Secretaria de Estado de Educação do Distrito Federal

SESP Serviço Especial de Saúde Pública

SIDA Síndrome da Imunodeficiência Adquirida

SI-PNI Sistema de Informação do Programa Nacional de Imunizações

SOE Serviço de Orientação Educacional

SUS Sistema Único de Saúde

UNICEF Fundo das Nações Unidas para a Infância 


\section{LISTA DE FIGURAS}

Figura 1 - Esquema de disposição dos espaços da escola ……………….......................................... 88

Figura 2 - Esquema hierárquico da escola ……….............................................................................92

LISTA DE TABELAS

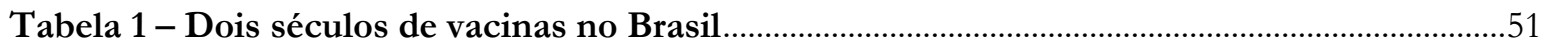

Tabela 2 - Tabela de distribuição de casos de câncer de acordo com o tipo (INCA, 2008) ........58 


\section{SUMÁRIO}

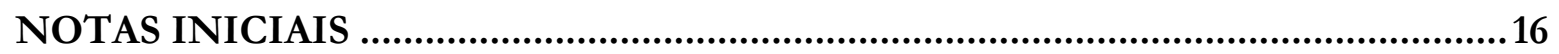

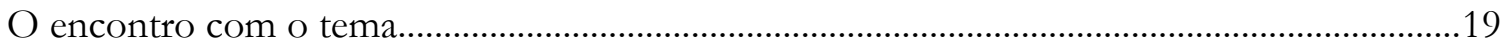

A "filha da professora" .............................................................................................................22

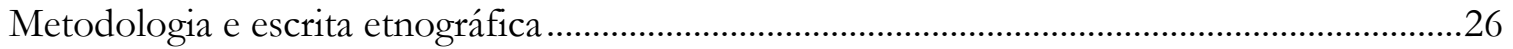

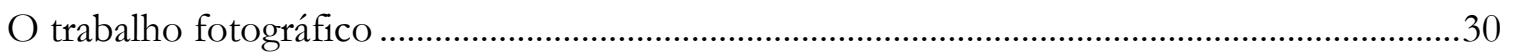

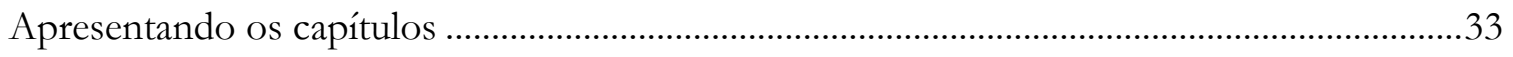

CAPÍTULO 1. PENSANDO O FENÔMENO VACINAL .........................................35

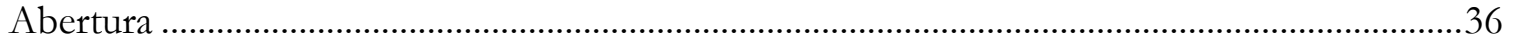

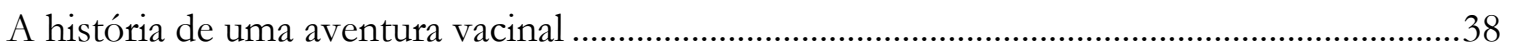

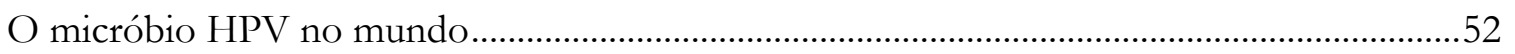

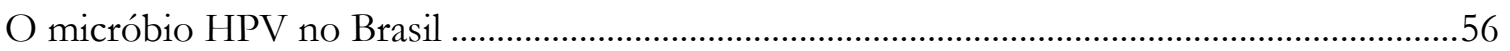

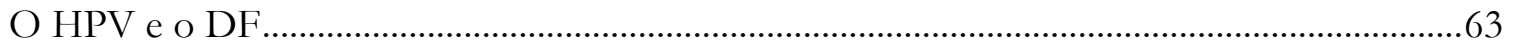

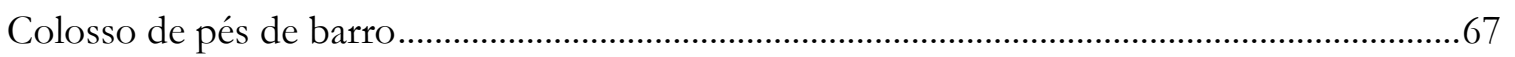

CAPÍTULO 2. A ENTRADA NA ESCOLA......................................................71

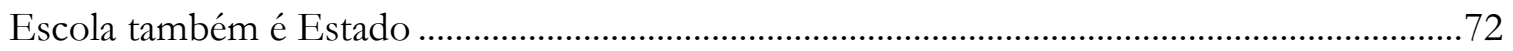

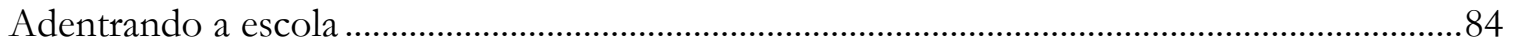

Cenário recôndito ou o âmbito das relações .........................................................................93

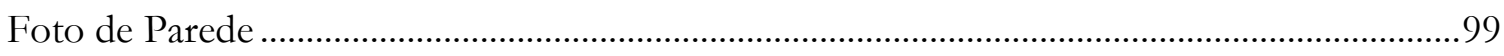

Entre cenário, personagens e vacina ........................................................................................111

CAPÍTULO 3. O DIA DA VACINAÇÃO .......................................................... 113

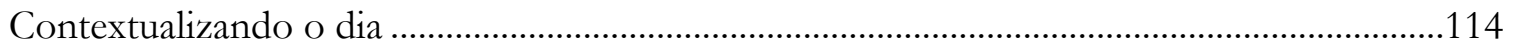

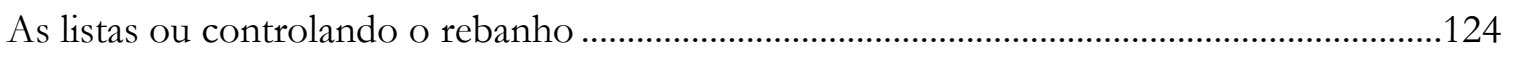

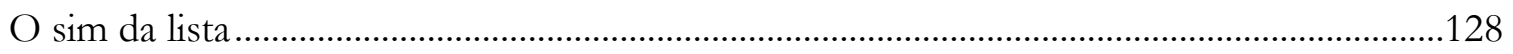

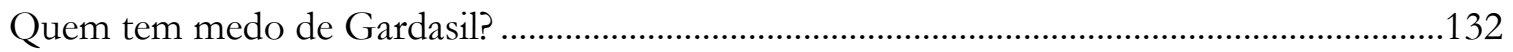

Escola e centro de saúde: parcerias e controvérsias ..................................................................136

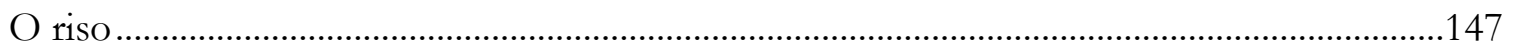

CAPÍTULO 4. OS SENTIDOS DO CUIDADO.................................................. 160

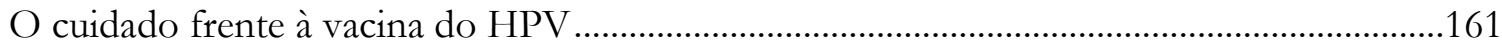

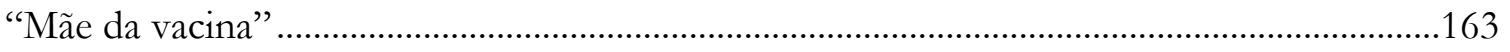


As vacinas dispensáveis e as indispensáveis............................................................................175

Os protagonistas empíricos do cuidado: a religião e o sexo .......................................................188

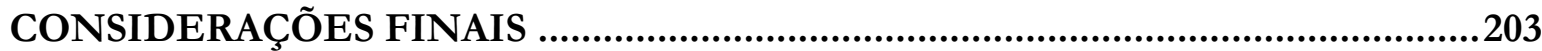

REFERÊNCIA BIBLIOGRÁFICA.............................................................208

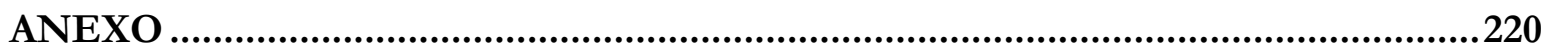

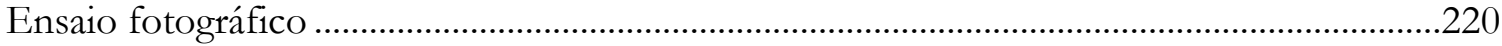


NOTAS INICIAIS

MENINAS TOMEM VACINA HPV

Hoje acontece a vacinação

No Colégio do meu Distrito,

É óbvio, para a prevenção

De um órgão menos visto

Como alojamento de vida

Que Deus cria no mundo.

Por isso as boas amigas

Tomam de gosto profundo

A importante vacina HPV.

E o Colégio tem parceria

Para então, ajudar prever

$E$ as mulheres terem alegria.

$V$ amos ficar imunes amigos,

Para evitarmos as doenças.

Usufruímos de algo sabido

E da nossa inteligência.

Às vezes ainda vemos casos

Por falta de compreensão,

Porém, vamos ser civilizados

E aceitar a boa vacinação

Para combater esses vírus

Que querem ficar fortes. 
Mas já estamos tranquilos

E mais distante da Morte

Agora os nossos cientistas,

Estão usando a sabedoria,

E contente o povo fica

Com a vacinação neste dia.

A nossa Enfermeira Nivonete

E as nossas Agentes de Saúde,

Maria e Terezinha merecem

Parabéns por sua boa virtude.

Mário Querino - Poeta de Deus

Assim o poeta baiano Mário Querino abre este trabalho. Ele busca justificar em seus versos o porquê da importância da vacina contra o Papiloma Vírus Humano - HPV e mostrar que vários tipos de "personagens" - colégio, escola, deus, mulheres, cientistas, povo - estão envolvidos, em alguma instância, por este processo vacinal. Lembra-nos também que para a prevenção de um "órgão menos visto" é necessário tomar a vacina, afinal, "ser civilizado é aceitar a boa vacinação".

Escolhi uma poesia sobre o HPV para iniciar este trabalho com dois propósitos. Primeiro, com o intuito de ilustrar que este tema ultrapassou as fronteiras da saúde e do mundo biomédico e está até mesmo na literatura. Porém, está também na internet, nos grupos de facebook; está no cinema, pois virou documentário²; está em letras de música, como no

${ }^{1} \mathrm{~A}$ expressão "vacina/vacinação do HPV" é de uso comum da autora, tentarei sempre me ater a ele. Outros termos, como "vacina HPV”, "vacina contra o HPV" também se apresentarão, apenas como variantes. Se houver alguma categoria do campo em relação a essas expressões, avisarei.

${ }^{2}$ Documentário intitulado Alguém que você ama: a epidemia do HPV, traz a história de cinco mulheres cujas vidas foram mudadas para sempre ou até interrompidas por conta desse vírus mortal. 
projeto Rap na saúde ${ }^{3}$, do Rio de Janeiro. A vacinação do HPV está sendo difundida em diferentes meios - fato. Mas, por qual motivo uma vacina ganharia tantos espaços diferentes? Investigar o mundo social que a envolve e a diferencia de outras vacinas é o objetivo central deste trabalho.

Segundo propósito. Uma poesia é importante, pois também se constitui texto informativo e cultural, mas em outro formato textual. Ela possibilita revelar o emaranhado social que circunscreve a realidade do poeta, por isso seu papel de informação crítico-reflexiva. Lévi-Strauss, teórico respeitável para a Antropologia, já diria (1997) que pode parecer contraditório, mas ele mesmo, que mais fez para transformar a Antropologia numa ciência dedicada às leis, seja tão sensível para a produção artística, ao encontrar ciência e traços culturais nos versos poéticos, bem como nos espetáculos, nas histórias em quadrinho, nas fotografias, estes reinos das subjetividades e das emoções. Diria ele que o poeta, por exemplo, estaria para a linguagem assim como o pintor para o objeto:

A linguagem se torna sua [do poeta] matéria prima, e esta que se propõe significar não exatamente as ideias ou conceitos que possamos tentar transmitir pelo discurso, mas esses enormes objetos linguísticos que constituem conjuntos ou pedaços de discurso. (LÉVI-STRAUSS, 1997 apud CHARBONNIER,1989, p. 98)

Por pedaços de discursos, o que esta poesia traz de mais significativo são alguns traços e fatos encontrados por mim como dados etnográficos em campo, que antecipam o que está por vir nesta dissertação.

São versos sobre a vacina do HPV formados a partir das palavras do poeta - talvez comuns ao olhar naturalizado, mas complexos ao olhar antropológico - que nos fazem refletir. Dentre estes versos, foi especialmente para a lógica simplista sobre a boa vacinação que esta dissertação se voltou. Como na poesia, este trabalho foi desenvolvido em uma escola pública do Distrito Federal, com um enfoque específico - conhecer a trajetória da vacina contra o HPV nesta instituição e o que, de fato, as pessoas estavam compreendendo sobre ela.

\footnotetext{
${ }^{3}$ O Rap da Saúde é um grupo formado por meio de um processo seletivo (com direito a bolsa) que visa formar jovens que atuem como promotores da saúde no âmbito da rede atenção primária, fortalecendo o protagonismo juvenil. É de âmbito da Secretaria Municipal de Saúde do Rio de Janeiro.
} 
A peculiaridade dessa vacina está envolta em todo o contexto social que engloba uma complexa rede de relações, de atores sociais, de percepções sobre vacina e doença. Como, por exemplo, apenas corpos jovens e femininos serem os alvos das campanhas à época, logo, recortes sobre corpo, gênero e geração entram aqui. Outro dado importante dessa campanha é que ela migrou de seu ambiente institucional - o centro de saúde - para as escolas. Tal prática dentro da escola - enquanto instituição de ensino, disseminadora de conhecimento, disciplinarizadora - gerou fatos interessantes.

O que chamou também a atenção deste estudo foi a recusa à vacina por parte de algumas pessoas, tanto neste estudo quanto no de outros pesquisadores. No Brasil, país de forte cultura de imunização (HOCHMAN, 2011), ter uma recente vacina, que promete proteger de uma doença estigmatizada como o câncer de colo de útero, e alguns pais e mães negarem este "benefício", era algo instigante para pensar. Esta vacina gerou muita controvérsia, então, quis entender um pouco os levantes e as implicações causados por ela.

Buscarei apresentar adiante algumas considerações sobre o mundo social da vacina HPV. Discorrer sobre as concepções das pessoas sobre ela, a quem pretendeu atingir (proteger), qual foi a percepção da escola frente a essa vacinação, como as mães e pais estavam se posicionando, quais tipos de resistências as pessoas apresentaram, e mais, como as próprias meninas, alvos da vacina, estavam compreendendo seus corpos frente a ela. Adianto que temas como sexualidade e religião foram partícipes importantes para o entendimento de muitas questões.

Assim, esta vacina chama atenção por suscitar problemáticas diferentes ao fenômeno do vacinar-se. Deve-se conhecer melhor essa variedade de temas, envoltos de ciência e poesia. Encontra-se, assim, a vacinação no “coração" das relações de poder e autoridade entre o estado, a ciência e os cidadãos (MOULIN, 2003), em particular agora, frente aos corpos femininos e jovens da periferia urbana.

\section{O encontro com o tema}

Longe desse ponto de análise seguro que apresento travestido por um poema, meus passos começaram tímidos. Voltar à UnB, depois de dois anos afastada, era um conquista 
pessoal, sair de um ambiente de trabalho puramente institucional e estar de volta à academia era desafiador. Logo no início do primeiro semestre procurei minha antiga orientadora da graduação - Soraya Fleischer, para uma conversa. Contei a ela que estava pensando em alguns temas, estes relacionados à saúde, mas não na mesma área da pesquisa anterior. Na graduação, pesquisei e etnografei a rotina de pessoas vivendo com doenças de longa duração ${ }^{4}$ - diabetes e hipertensão, dando ênfase à relação que estas tinham com seus aparelhos medidores de glicemia e pressão arterial. O trabalho foi desenvolvido dentro de um centro de saúde em diálogo com a vizinhança, onde pude frequentar as casas. Boa parte dos meus interlocutores eram senhoras e senhores, com tempo menos comprometido e mais disponível para conversas. Este trabalho intitula-se "Bombinha, reloginho ou pera: $\mathrm{O}$ uso de equipamentos biomédicos no cuidado da saúde de pessoas vivendo com hipertensão e diabetes na Guariroba, CeilândiaDF", e foi defendido no final de 2011.

Soraya me ouviu, gostou de muito de várias ideias que apresentei. Porém, quis ouvi-la também. Perguntei a ela o que de novo estava pesquisando, quais eram os planos para aquele ano. Ela me contou sobre algumas inquietações, dentre elas, que estava em cena a vacina do HPV [até então nunca tinha me atentado para ela, embora já tivesse ouvido várias vezes], e o que mais chamava a atenção de Soraya era a migração dessa vacina do $\mathrm{CS}^{5}$ para as escolas. De fato, ao conversarmos, o tema foi se tornando muito interessante. Bem, não formalizamos nenhuma parceria, ela queria que eu tivesse contato com outras matérias, outras ideias e áreas de pesquisa. Ainda sim, sugeriu que eu ficasse atenta aos jornais, às mídias. E assim fiz.

Cada vez que eu pesquisava sobre HPV, eu ficava mais entusiasmada. Não era uma vacina por si só, tinha mais "coisa" ali, sentia eu. Ao longo do primeiro semestre $\left(1^{\circ} / 2015\right)$ fiz um levantamento jornalístico, um clipping de mídia ${ }^{6}$, e fui guardando todas as reportagens que dariam "mais caldo", afinal, os afluxos temáticos sobre vacinas eram inúmeros, como movimentos antivacinistas, campanhas de imunização, técnicas de controle do Estado, surgimento de novas vacinas (SIDA, Hepatites, Hipertensão, Dengue, Zica). Entretanto, minha escolha tinha que ser pontual. Pela internet descortinei os recortes que mais me inquietavam e que perpassavam a discussão do HPV, tais como: a restrição da vacina para os

\footnotetext{
4 Termo utilizado pela pesquisadora Ana Maria Canesqui.

5 Peço licença para abreviar, algumas vezes durante a escrita, as palavras "centro de saúde" por CS, ou usar a palavra "posto de saúde" ou "posto" como sinônimo destas.

${ }^{6}$ Espécie de arquivo jornalístico, geralmente virtual, sobe um tema pesquisado.
} 
homens, a diminuição da procura pelas segundas e terceiras doses, a desconfiança dos pais e mães, os grupos contrários à vacina, entre outros. Isso era muito instigante.

Resolvi, então, procurar no Guará, cidade onde moro no DF, se ainda havia vacinação nas escolas, pois naquele momento (meados de 2015) o governo local queria levar de volta as vacinas para os centros de saúde - queria saber o porquê também. Fui até o CS mais próximo de casa [que me é familiar, pois sempre vou até lá pegar os remédios da minha avó] a fim de obter informação. Lá conheci Lorena, uma técnica de enfermagem muito simpática, que ficava sempre numa mesinha próximo à entrada do CS - estávamos em meio à campanha da vacinação da gripe, ter uma mesa ali na porta facilitava a procura pela vacina. Lorena foi simpática, era conhecia todos ali, sabia dos calendários de vacina, sabia muito sobre o HPV. Fiquei muito entusiasmada com ela, queria conversar com mais calma, sondar o campo. Expliquei a ela minhas intenções de pesquisa e propus uma conversa. Claro que falhas iniciais aconteceram, ela chegou a "furar" alguns encontros, mas na terceira vez, consegui uma entrevista.

Em um dia mais calmo, sem tumulto no CS, ela topou uma conversa mais informal, ali mesmo, no corredor. Era muito dinâmica em sua fala, explicava tudo direitinho. Ela me contou muitos fatos sobre a vacinação que ocorrera no Guará - escolas desorganizadas, meninas em pânico, o medo da agulha - entretanto me informou que os CS do Guará não estavam mais indo às escolas, e afirmou "vacina agora só no Gama" - outra cidade do DF. Embora Lorena fosse uma interlocutora "de primeira" (por ser simpática e comunicativa), descartei fazer o campo por ali, afinal, queria ver uma vacinação “ao vivo e a cores”. Após pensar alguns dias sobre isso, voltei ao CS para comunicá-la que não ficaria por ali.

Neste dia, um fato estranho aconteceu. Quando voltei ao CS para avisa-lhe que não ficaria por ali, Lorena estava em um dia de vacinação contra gripe. Este dia, minhas tias ao saberem que eu iria até o posto, aproveitaram a carona para tomarem esta vacina. Lorena, ao me ver com elas, e mesmo com a minha expressa indecisão sobre a vacina, aplicou-me a dose. Trago uma parte do diário para contextualizar melhor:

Já na vez das minhas tias vacinarem, juntei-me a elas para poder me inteirar da vacinação, já que queria observar mais, ia pesquisar sobre isso... Primeiro foi a Bárbara, depois a Socorro. Nesse instante, como estávamos as três perto da Lorena. Nisso, ao terminar de aplicar a vacina na Socorro, ela olha pra mim e pergunta: "você já tomou? Baixa a blusa aí". Falou isso bem baixinho, apontando para o meu braço, e já foi 
tirando minha blusa. Eu fiquei sem saber o que fazer. Eu não me encaixava nos critérios exigidos pela campanha (idosos, bebês, diabéticos...), não tinha ido tomar vacina, estava numa crise sobre a validade desses "remédios" e tudo mais. $\mathrm{Na}$ verdade, na verdade, não queria mesmo. Então veio o "golpe". Minhas tias ficaram me incentivando a tomar: “aproveita, aproveita!", Lorena já estava com a vacina prontinha na mão, já chegando perto do meu braço. Aí, tomei! (DIÁRIO, 19 de maio de 2015)

Agradeci meio sem graça a Lorena, que pareceu muito contente em me dar uma vacina. Foi até anotar no caderninho essa nova dose que tinha aplicado. É fácil imaginar que vários pensamentos invadiram minha cabeça nesse dia. Pensei muito sobre as vacinas. Elas seriam dádivas? Realmente são bens de valor que devemos aproveitar? Lorena teria sido invasiva ou estava apenas querendo me agradar? Sofreriam as meninas do HPV essa pressão que eu havia sofrido? A família é determinante da hora da vacina? Foram reflexões que abriram de vez o campo das vacinas para mim. Esse era o tema que eu queria pesquisar.

Bem, assim cheguei ao campo/tema de pesquisa. Uma dupla chegada, pois eu havia decidido que ficaria mesmo com o tema do HPV, vistos os recortes temáticos narrados por Lorena e que eram instigantes para pensar e que reforçavam o que eu tinha lido nas reportagens coletadas; e segundo, eu havia encontrado um campo: uma escola pública no Gama que ainda receberia a vacinação.

\section{A "filha da professora"}

No campo escolhido para estudar a vacinação do HPV, me dediquei a conhecer a rotina de uma escola pública, de ensino fundamental, localizada na cidade do Gama, a qual foi uma das últimas cidades (e escola) a receber a vacinação in loco, pois logo em seguida esta retornaria aos CS. Em diálogo com a escola, também recorri ao CS responsável pelo processo de vacinação da região, visitei algumas casas nas quais as mães, em geral, toparam conversar. Contatei muitos profissionais dentro da escola, dentre servidores da educação e da saúde e, mais uma vez, também mães e pais.

A aproximação com o tema das vacinas foi, de certa forma, uma ruptura com minha pesquisa anterior em alguns aspectos. Ao invés de casas tranquilas, tinha agora um lugar de 
pesquisa barulhento e movimentado, cheio de adolescentes enérgicos no lugar dos idosos. Jovens esses que conversavam no ritmo deles, no tempo deles, do jeito deles. Precisei reaprender algumas "etiquetas" dessa juventude, como me adaptar às gírias, modos de ganhar confiança, ser receptiva aos abraços de toda hora (as garotas sempre se mostraram muito carinhosas), e mesmo relevar algumas atitudes por parte dos jovens, afinal tudo faz parte da aprendizagem "intuitiva e experimental com tais imponderáveis, os quais nem sempre constam nas análises” (BONETTI; FLEISCHER, 2007, p.7). Enfim, pesquisar em escola não é algo simples.

O que posso adiantar é que meu papel em campo transitou por diversos personagens. Geralmente não espero ser vista como pesquisadora, muito menos como antropóloga, até hoje nunca me categorizaram, em campo, como tal. Para mim, são os "adereços" que carregamos que nos conferem identidade, às vezes, muito mais do que explicarmos o que fazemos. Por exemplo, usar o caderno de campo e anotar em público me trouxe a identidade de uma jornalista. Ou quando entrava em alguma sala com papéis e um coque nos cabelos, diziam "acho que ela é a nova professora". Para a vice-diretora da escola, eu era estagiária de alguma disciplina, embora toda vez eu falasse que estava ali para uma pesquisa. Quando não, era mais uma servidora da escola, pois como diziam “essa aí já é servidora, vive lá na escola”. Dessa vez, experimentei trabalhar com uma máquina fotográfica em campo (falo disso mais a frente), logo, era fotógrafa ou jornalista novamente. Entretanto, de todos eles, o papel que mais me definiu e me marcou foi “ela é filha da professora Kátia!” (DIÁRIO, 3 de junho de 2016).

Este é um fato que preciso contar. Por coincidência, a escola que ainda receberia a vacinação era também onde havia um familiar meu presente. E não era um primo distante de quarto grau, era minha mãe. Ter alguém muito próximo em campo apresentou-me seus louros, e também, agouros. Minha mãe abriu-me portas, era um contato importante em campo, foi minha interlocutora, ajudou-me a localizar as garotas e mães com quem queria conversar, de fato, expandiu meu campo. Entretanto, não havia um dia sequer que eu não tenha estado na escola e que a minha figura não tenha sido associada a ela, cito exemplos "olha a filha da professora", “xerox da Kátia!”, “sua mãe estava te procurando”, "Katinha 2". Eu não sabia, até aquele momento, que eu parecia tanto fisicamente com a minha mãe, tamanha as comparações.

Combinamos, eu e ela, que na frente dos estudantes, nos trataríamos de maneira mais contida (adoramos sorrir juntas e alto), para que isso não gerasse uma curiosidade extrema e 
pudesse interferir no andamento da pesquisa. Eu receava que as alunas e alunos ficassem tímidos nas conversas e entrevistas por saberem que eu era filha de uma professora e que, talvez, a "hierarquia" entre eles pudesse ser projetada em mim. Então, ela sempre falava “pessoal, a pesquisadora precisa conversar com duas meninas...”, “a Natália vai acompanhar uma de vocês...", ou mesmo negava quando perguntavam sobre nosso parentesco, desconversava. Mas os adolescentes insistiam ou "jogavam verde". Quando minha mãe e eu não conseguíamos representar bem nossa "distância", contávamos a verdade, porém, pedíamos descrição. Aqui uso as ideias de Goffman (2014), que afirmam que grande parte do comportamento das pessoas no cotidiano é semelhante ao de atores no palco, sendo que os indivíduos e os grupos estão constantemente representando uns para os outros, pois

Uma vez negociado e compreendido o que está em jogo em uma dada interação, o indivíduo passa a gerir a apresentação do seu Eu (Self) em relação às impressões anteriormente estabelecidas, com vistas a alcançar objetivos formulados previamente, de maneira consciente ou não. (2014, p. 119)

Até que em um momento, ao ler sobre pesquisas etnográficas contemporâneas e seus desafios, uma das sugestões que os autores davam para o surgimento de questões mais sensíveis em campo (no meu caso, administrar uma mãe em campo) foi exatamente dar voz a estas questões, algo que até então, eu e ela não estávamos fazendo.

Surgiram, contudo, algumas sugestões de estratégias para se lidar com os "riscos". Visibilizá-los é a primeira delas, o que significa defrontar-se com eles e incorporá-los como um eloquente dado de campo que, por exemplo, revela ao etnógrafo como ele está sendo compreendido naquele contexto específico da pesquisa ou revela os limites que existem e que precisam ser respeitados pelo visitante e os visitados. (BONETTI; FLEISCHER, 2007, p.13)

Rangel (2015), que fez campo em um circo no qual sua mãe trabalhava, apontou que fazer etnografia enquanto filho não foi um empreendimento difícil, pois ele sempre se lembrava de que:

O familiar não é necessariamente conhecido, o que faz diferir as nossas pesquisas parece ser menos o grau em que admitimos habitar relações prévias ao campo e mais em que medida as levamos a sério. $\mathrm{O}$ meu trabalho foi o de me acolher com profusão 
em relações reconhecendo que seriam elas o que eu intentaria descrever, e não meras derivas autocentradas. (2015, p. 150).

Decidimos, minha mãe e eu, com base no conselho de "visibilizar os riscos", deixar as situações de parentesco fluírem normalmente, afinal, elas poderiam proporcionar reflexões. Conquanto estas questões, o campo foi muito mais de louros. Não notei recusas por parte dos meus interlocutores por conta da filiação. Não a nível macro, explícito. Entretanto, sei que podem surgir questionamentos quanto à qualidade das informações ou neutralidade desejadas em campo,

Por mais que a familiarização do exótico ou o estranhamento do familiar (Velho, 1988) sejam movimentos necessários e desejados em nossa prática, parece que a Antropologia consensua ao redor de um limite. Ele anuncia que o "risco de proximidade" ainda persiste porque sustentamos o mito da objetividade e neutralidade como sinônimo de qualidade e excelência acadêmicas. Rever mais este mito, como lembrou uma partícipe, "é um risco epistemológico", que por sua vez, "é sempre um risco político". Acreditamos que ambos riscos ajudam a avançar a disciplina. (BONETTI; FLEISCHER, 2007, p. 11)

Não há como tentar ser um "antropólogo-herói” (ibid., p.11), ou seja, neutro, distante e ávido no controle dos fatos, ainda mais ao ser fazer uma Antropologia Urbana, afinal, estamos em um campo muito familiar, que requer um esforço de estranhamento. Os riscos serão de várias ordens e não dá para ter a percepção plena de todos eles ou suas implicâncias. O campo é viver. Incluo aqui até o sentido pessoal dessa experiência, pois pude aproximar-me mais da minha mãe, já que nunca morei com ela. Fiz parte de sua rotina e ela, reciprocamente da minha, isto foi bom para pesquisa e para a vida.

Para encerrar, ainda sobre a pesquisa de campo, preciso frisar dois pontos. Primeiro, neste trabalho, não há intenção de formalizar um modelo de política pública ideal de vacina. A narração das histórias que serão contadas pertence a um momento específico vivido, tal como uma fotografia, pois é necessário ter em mente que as relações sociais se alteram a todo instante e o que hoje existe, amanhã pode não existir mais, e há ainda a seleção de histórias por parte da autora, que recortam mais uma vez o tema, afinal,

O observador é parte integrante do processo de conhecimento e descoberta, pode-se dizer, como já se fez anteriormente, que na antropologia não existe fato social, mas 
"fatos etnográficos", salientando que houve seleção no que foi observado e interpretação no relato. (PEIRANO, 1991, p. 44)

E mais, Cunha e Durand (2011) dizem que embora a vacinação e seu princípio universal de proteção seja encarado como uma solução global, as atitudes que se vivenciam hoje face à vacinação estão a mudar ou desestabilizar essa ideologia, ao menos muito superficialmente. $\mathrm{O}$ estudo sobre a vacina do HPV me mostrou como as pessoas andam comungando perspectivas culturais e experiências individuais frente aos cálculos, por vezes muito distantes, das informações científicas. Talvez seja sobre essa "tendência" de mudança que a vacina HPV queira nos dizer algo.

Segundo, diante da infinidade de análises possíveis do tema, uma tornou-se fundamental frisar. Em nenhum momento a discussão deste trabalho teve a intenção de questionar, provar ou negar a eficácia ou eficiência da vacina do HPV (salvo quando trazido

pelos interlocutores), no sentido de ser segura ou não para as jovens, proteger o corpo de fato como preconizado, ou consistir em uma ameaça, como apontam os movimentos antivacinistas.

\section{Metodologia e escrita etnográfica}

A trajetória desta pesquisa que desemboca nesta dissertação foi realizada por meio da etnografia. Ideia central na Antropologia, tratar a etnografia como método a esvazia de seu significado, conforme Peirano (2014), “métodos (etnográficos) podem e serão sempre novos, mas sua natureza (...) é antiga. Somos todos inventores, inovadores. A antropologia é resultado de uma permanente recombinação intelectual" (p. 3). Sendo a etnografia muito mais uma maneira combinada de diferentes formatos de se fazer pesquisa, ela permite à pesquisadora uma abordagem aprofundada das questões que se propõe a estudar e/ou que surgem como relevantes aos próprios interlocutores em campo e que se materializam em práticas e discursos.

Muitas vezes vamos a campo com alguns temas pré-determinados, buscando encontrar respostas para certas perguntas, entretanto quando nos deparamos com a riqueza de detalhes oferecidos por nossos interlocutores, descortinam-se novos temas que merecem ser levados em consideração ou até mesmo, merecem uma pesquisa exclusiva. Nisso está a diversidade da 
antropologia. Ela permite, até certo ponto, que a pesquisa agregue novas temáticas, sem esquecer seu referencial, o ponto de partida que neste caso foi a vacinação do HPV nas escolas, e logo, o mundo social que se abriu com ou a partir deste. A mudança de foco que a perspectiva antropológica permite, especialmente por causa do uso da etnografia, tem a vantagem de evitar que enormes dicotomias surjam entres os atores sociais e a investigadora, ou que pressupostos da segunda ocultem a perspectiva dos primeiros.

A presente pesquisa, pela orientação de dar voz aos sujeitos estudados, em especial às meninas alvos da campanha, não teve, a priori, a intenção de produzir generalizações para todos os grupos que se assemelhem ao estudado. E também, relembrando algo que falei acima, a etnografia funciona como uma fotografia, que capta certo momento em certa situação, não se pretendendo fixo, muito menos eterno. Por isso mesmo, quando narrados os fatos, peço a licença para usar o tempo verbal no pretérito, a fim de fixar esta ideia.

A etnografia realizada aconteceu por meio da convivência com os sujeitos em campo, os quais foram se mostrando dispostos e interessados a participarem dela. A partir de concordância voluntária, entrevistas foram realizadas por meio de um roteiro de perguntas semiestruturado, quando possível. Conversas informais e inesperadas também se tornaram fontes importantes de informação. Nos casos de entrevistas, a gravação foi usada, mediante permissão, e depois transcritas. Pude conversar com diferentes atores em campo, mais à frente explicarei melhor quem são eles. Devo ressaltar que muitas conversas tidas na escola ou no posto, foram rápidas, e por isso muitas vezes, ao longo do texto, não há a descrição completas das conversas ou dos personagens, bem como a contextualização das cenas e dos fatos. Foram diálogos com pouco contexto, rapidamente diluídos em um ambiente tão rotativo como uma escola em constante "ebulição".

Para a entrada na escola apresentei meu projeto de pesquisa e o comprovante de vinculação ao departamento de antropologia à vice-diretora. Qualquer outro tipo de documento ou parecer do comitê de ética não foi solicitado, no entanto, isso não me eximiu da preocupação de pensar a pesquisa com menores de idade orientada por questões éticas. Por isso, solicitei à vice-diretora uma declaração por escrito que autorizasse minha presença e pesquisa nas dependências da escola. Mas não só isso. Tive o cuidado de conversar com os/as adolescentes sempre em grupo, geralmente na sala do Serviço de Orientação Educacional SOE, quando esta estava ocupada, ficava em locais públicos, como o pátio. Tomei estas 
precauções porque falar de vacina HPV era, por vezes, fazer brotar temas como sexualidade, corpo, relacionamentos. E para a escola, eram temas espinhosos. Falarei com calma sobre isso no capítulo três e quatro.

Dentro ainda das questões éticas, e porque não políticas, preciso frisar que omiti o nome da escola e, no que diz respeito às pessoas contatadas, escolhi pseudônimos para todas elas, afinal

Escolher pseudônimos para as pessoas que participaram da pesquisa é um recurso metodológico que identifica as interlocutoras e os interlocutores como sujeitos da pesquisa e ameniza a possibilidade de essas pessoas serem identificadas por outras pessoas que não aquelas que participaram dos momentos relacionais vivenciados - é preciso considerar que é inevitável o reconhecimento de si e de outras pessoas do grupo pesquisado através das histórias fixadas neste texto. (DINIZ, 2014, p. 35)

Quanto à política, não pretendi em momento algum fazer uma antropologia denunciatória ou de julgamento. Por isso não marcar o lugar com nomes também. Outra questão, esta inculcada em mim a partir de Diniz (2014), foi atentar-me a colocar o feminino antes do masculino (p.ex.: mães e pais, alunas e alunos), afinal, foi majoritária a presença feminina dentre as pessoas com quem conversei. Faço, por vezes, uma intercalação de gêneros nas ordens das palavras, tentando, ao menos, desnaturalizar o genérico do masculino em nosso idioma.

Destaco que dialogar, perguntar, ouvir histórias, sorrir com o público adolescente (estudantes da escola/ensino fundamental) foi gratificante, pois, geralmente, eram sujeitos espontâneos, com muita energia e disposição, que gostam de conversar, gostam de perguntar, interagiram junto à pesquisadora, assim "retroalimentando" o fazer antropológico. Não há nada melhor do que encontrar um interlocutor que goste de falar, de se dedicar às perguntas de cunho etnográfico e que ao respondê-las seja simples e ao mesmo tempo verdadeiro, esta é uma característica do público jovem que conversei. Foi uma das melhores experiências em campo: aprender a ouvir as longas histórias dos adolescentes, habituar-me à linguagem deles, as quais trazem, intrinsecamente, ricos dados etnográficos.

Em suma, para ter uma ideia da minha inserção e produção em campo, estive em campo por seis meses em 2016. Porém a vacinação que acompanhei, ocorreu em 2015, por 
isso visitei a escola algumas vezes durante aquele ano. Ouvi aproximadamente 34 meninas narrarem seus processos de vacinas, organizei dois grupos focais com meninos (foram 6 garotos ao todo), fiz três visitas ao CS responsável pela vacinação, conversei com 6 mães e 1 pai, entrevistei 5 profissionais da escola e 6 profissionais do centro de saúde. Participei de eventos da escola, de reuniões de pais e mestres e frequentei a escola em alguns finais de semana, momento que ocorriam os jogos escolares.

Eu registrava os dados encontrados no caderno de campo; quando permitido, gravava as entrevistas e; para a organização e registro sistemático, os diários de campo eram escritos sempre no mesmo dia da observação, a partir das anotações do caderno e das entrevistas. Um tomo cronológico de diários de campo também foi montado e impresso, a fim de ajudar na organização e periodização dos dados. Ao final do campo, os dados contidos nos diários foram organizados para esta dissertação, por temas ou blocos, como entrevistas, partes importantes, "sacadas" teóricas, entre outras.

Até agora apresentei os pensamentos e posturas que me conduziram na pesquisa em si. Gostaria de comentar que no processo de escrita da dissertação pensei em diferentes formatos de apresentação do texto, o qual poderia ajudar com que eu me expressasse com clareza e criatividade. Nesse sentido, além de trazer o diário de campo no formato de diálogo, com a minha voz presente, faço citações em inglês e espanhol traduzidas por mim, mas que terão o original em nota de rodapé. Além disso, o clipping de mídia montado com as notícias jornalísticas sobre a vacina também se revelou um bom recurso didático, ao fornecer "gatilhos" temáticos para esclarecimento de algum assunto, então integram o texto também. Por último, em cada abertura dos capítulos, apresento algumas estrofes não lineares do poema de abertura, com a intenção de adiantar o tema que será trabalhado na sequência. Eles podem suscitar reflexões sobre as peças cotidianas vivenciadas em campo que virão a seguir.

Todo este percurso metodológico, desde a primeira ida a campo ainda no Guará, até o desenvolvimento das atividades relacionadas acima, já no Gama, contribuíram de maneira intensa para a tentativa de pensar e descrever sobre o que me propus a conhecer com o meu estudo sobre a vacinação do HPV em uma escola do DF, a que chamo escola do Gama. Mas, além disso, as experiências vividas me ajudaram a amadurecer meu lado "antropóloga" e também "pessoal", afinal, como explicita Claudia Fonseca, "ninguém nega que somos parte da realidade que pesquisamos. (...) ao reconhecer que existem outros "territórios", ele - o 
pesquisador - alcança a reflexividade almejada" (1999, p. 65). Tal reflexividade ajudou a selecionar, analisar, descrever e apresentar melhor os dados que serão apresentados adiante e também ajudou a repensar minha prática e inserção como pesquisadora.

\section{O trabalho fotográfico}

Uma das melhores descobertas no mestrado foi o encontro com a fotografia. Enquanto antropóloga, nunca tinha me dado conta que trabalhar com imagens seria algo tão positivo, ao mesmo tempo, desafiador. A antropologia visual é um campo múltiplo de teorias, imagens e representações. Dentro do campo da antropologia cultural, ela oferece a possibilidade da utilização e da reflexão acerca de produtos audiovisuais dentro de um contexto de pesquisa. Segundo Guran (2000, p. 99) "o que se espera das fotos é que elas tenham o máximo de eficácia quanto à transmissão da informação”. A eficácia de uma foto está ligada a uma boa montagem de cena, a uma sequência bem planejada, às legendas, ao conteúdo que se pode apreender delas. Ela ilustra e complementa (por vezes substitui) o texto.

No passado, foi chamada de "antropologia da urgência" (ALTMANN, 2010), por capturar imagens dos povos que supostamente estariam desaparecendo - de certa forma uma imagem intenta "cristalizar" o presente. Hoje, a antropologia visual apresenta-se mais complexa, pois envolve questões profundas em seu fazer, tais como metodologia, epistemologia, técnicas visuais, ética. Dentre seus temas e desdobramentos, há uma abordagem que se destaca a mais de meio século, que é a etnoficção. Trago a ideia da etnoficção pois a utilizei em algumas fotos. Seu "criador" foi Jean Rouch, antropólogo francês, criador de renomados filmes como Os mestres loucos (1954-1957), Eu, um negro (1959), Petit a Petit (1970). De modo geral, tem-se uma etnoficção quando:

Existe uma espécie de mistura entre documentário e ficção na área da antropologia visual. Refere-se a um filme cujas personagens, nativos, recorrendo a uma narrativa ficcionada ou à pura imaginação, muitas vezes improvisando, desempenham o seu próprio papel como membros de um grupo étnico ou social. (ALTMANN, 2010, p. 4) 
Rouch assim fez. Ao longo de sua carreira, Jean Rouch foi dando voz, muitas vezes literalmente, a seus interlocutores, o que acabou por conferir a seus filmes viés participativo. Longe de empreender uma etnoficção a la Rouch, usei a proposta desta em algumas fotografias desse trabalho, como uma maneira de trazer imagens de um momento que não mais existia, que foi o dia que a escola recebeu a vacinação. Como esse dia aconteceu no ano de 2015 e eu ainda não trabalhava com fotos, propus às minhas interlocutoras, a montagem e representação de algumas cenas do dia da vacinação. Para exemplificar, a foto de capa que abre esta dissertação, mostra as meninas em fila, aguardando sua vez de vacinar. Tal foto não foi tirada no dia da vacinação, mas com a ajuda das interlocutoras, pude retratar a cena.

A necessidade de obter imagens fotográficas de um processo que não mais aconteceria, mas que precisava ser remontado, e que era possível de ser representado pelas pessoas, fez com que a opção pela etnoficção se mostrasse factível. Trabalhar com o tema das vacinas, e não fazer disso imagens óbvias (tais como pessoas sendo vacinadas), conferiu a essa experiência um dos pontos altos da produção.

Pesquisar sobre vacinas é muito específico e subjetivo, pois apresenta aspectos não tangíveis, não mensuráveis, como sentimentos, dores, ações, reações, processos e falas, logo, difíceis de retratar, de transformar em imagem. Por isso a tentativa da etnoficção. Os interlocutores seriam preciosos para contar como foi a vacinação, ajudar a montar o caminho da vacina pela escola, a encenar seus próprios papéis. Esta foi uma saída encontrada por mim para apresentar a vacina por outro recorte que não o biomédico.

Nesta dissertação, apresento dois momentos distintos do trabalho com as fotografias. $\mathrm{Na}$ ordem cronológica de produção, cujo primeiro trabalho foi feito em 2015, trago imagens do ensaio que realizei para a disciplina de Antropologia Visual, o qual intitulei Quando a vacina entra na escola. Para este ensaio, utilizei a ideia da etnoficção e precisei da ajuda ativa dos meus interlocutores, como expliquei acima. A ideia das fotos era apresentar o caminho que a vacina HPV percorreu dentro da escola. As fotos representam desde o momento que a vacina é "negociada" entre o CS e a escola, até o momento da pós-vacinação. Intentou-se captar como socialmente esse fenômeno se "inicia", se divulga, se espalha, se concretiza e é perpetuado dentro de um contexto escolar. Algumas fotografias dele usarei durante a escrita.

Mas, além disso, trarei este ensaio completo ao final do trabalho, Anexo A, para demonstrar como este ensaio foi exposto, por meio do ciclo de exposições fotográficas anuais 
realizadas pelo IRIS - Laboratório de Imagem e Registro de Interações Sociais - que é uma seção do Departamento de Antropologia da UnB (DAN) e que visa subsidiar, apoiar e promover o uso de recursos audiovisuais em atividades de pesquisa, ensino e extensão dos docentes e discentes do Departamento. A exposição ficou aberta ao público durante três semanas, durante o mês de Outubro de 2016. Pretendo que este ensaio fotográfico seja devolvido ao campo por meio de uma exposição que será montada na escola do Gama.

Em um segundo momento, este realizado no ano de 2016, fui a campo com a máquina. Pude senti de fato a repercussão da câmera, mas não produzi ensaios temáticos. Buscava retratar o que chamasse minha atenção, que ajudasse a entender o campo, a retratar o que as palavras não alcançavam. Senti-me mais livre, menos preocupada com a câmera fotográfica ali. Tirei foto por onde andei, com quem conversei, sempre quando autorizada, me preocupando com os cuidados jurídicos quanto à proteção da identidade das/os adolescentes. Conforme forem surgindo os temas ao longo do trabalho, irei utilizando as imagens. De qualquer modo, os dois momentos, o ensaio (feito em 2015) e as fotos soltas (feito em 2016), exigiram desdobramentos diferentes, tais como negociações com a Direção da escola, registro de momentos cruciais, olhar atento para as sutilezas do tema, sensibilidade antropológica e artística, dentre tantas outras demandas.

Quanto às técnicas fotográficas em si, não pretendo me auto intitular "profissional". Esta foi a minha primeira oportunidade de trabalhar com fotografia, senti dificuldade em concatenar fatores como luz, cenário, planos, pessoas, focos, clímax, entre tantas outras artimanhas que jogam a favor de uma boa fotógrafa e contra a amadora. Para o tratamento das fotos, contei com informações obtidas no IRIS quanto ao uso do Lightroom (programa para tratamento de imagens).

Este trabalho tratou não apenas de produzir registros fotográficos, mas de fazer das imagens uma forma de conhecimento, uma maneira de produção de representações densas, que pudessem iluminar universos simbólicos em relação ao tema pesquisado. Às vezes a apresentação de uma foto, mesmo de algo conhecido, familiar, revela aspectos que acompanhados de diferentes sentidos, nos levam a outros mundos, a novas compreensões. Foi o que tentei fazer quando falo da vacina especificamente. Espero ter alcançado esta tarefa, ao menos em parte. 


\section{Apresentando os capítulos}

Ao todo, além da introdução e da conclusão, dividi meu argumento em quatro eixos. No capítulo um, Pensando o Fenômeno Vacinal, abordo o Estado e sua gestão acerca da vacina. Falar sobre políticas, programas de vacinação e história da vacina ajudam nesta tarefa. Traço uma linha cronológica com o intuito de facilitar a ilustração de como a vacina, desde sua criação, tornou-se uma tecnologia importante para o controle e a ordem tanto social quanto dos corpos. Caminho também pela apresentação do vírus HPV e do surgimento da vacina, localizando as ações e as políticas sobre esta no âmbito do Brasil e do Distrito Federal.

No capítulo seguinte, A Entrada na Escola, apresento o campo de pesquisa: os bastidores da escola. Suas estruturas físicas e hierárquicas, e também, suas estruturas recônditas. Recônditas no sentido de apresentar as relações sociais que na escola se desenvolvem e podem melhor configurar os dados do campo. São as relações interpessoais ali existentes que abrem espaço para as configurações socioculturais dos adolescentes, seus modos de vida, seus conflitos e suas brincadeiras. A relação entre eles e os servidores, e estes entre si, também são abordadas. Por outro lado, discuto o fato de a escola ser uma instituição do Estado, perpetuando suas condições e ideologias. Relato também sobre minha entrada em campo. Considero esta contextualização importante, pois conhecer o cenário que a vacina foi recebida abre caminhos para reflexões diversas.

No terceiro capítulo, O Dia da Vacinação, narro o dia que estive presente durante a vacinação do HPV. Discorro sobre como a escola se preparou, que personagens estavam em cena, trago a voz de vários interlocutores, em especial, a voz das meninas e dos meninos e suas concepções e posicionamentos sobre a vacinação. O aprendizado destes sobre seus corpos e papéis sociais é explorado aqui. Por meio de questionamentos sobre a vacina pude apreender o que os adolescentes sabem ou querem saber sobre todo esse processo vacinal. Entre parceria e controvérsia, discuto a percepção dos profissionais da saúde e da educação acerca de suas atividades e atribuições sobre a vacinação dentro da escola. A vacinação HPV é feminina? O que isto pode implicar? Há uma seção só para esta discussão.

E por último, o capítulo quatro, Os Sentidos do Cuidado. Esse foi difícil e bonito de ser pensado e escrito, pois conecta sexualidade, religião, gênero e cuidado, a partir da ótica das 
mães e dos pais sobre a vacina. Aqui as subjetividades, as histórias e os valores de cada um afloraram. O "sim" e o "não" dados pelas mães à vacina HPV aparecem por aqui, porém ambos acabam por expressar cuidados parecidos. Deixemos o assunto para seu tempo. Dito isso, sigamos. 


\title{
Capítulo 1. PENSANDO O FENÔMENO VACINAL
}

\author{
Para combater esses vírus \\ Que querem ficar fortes. \\ Mas já estamos tranquilos \\ E mais distante da Morte
}

Agora os nossos cientistas,

Estão usando a sabedoria,

E contente o povo fica

Com a vacinação neste dia. 


\section{Abertura}

Olhe, toque seu braço. Toque um pouco abaixo do ombro. Ela geralmente está no braço direito. Passe a mão e tente achar aquela marca que parece uma cicatriz, aquela que temos desde bebê. Achou? Bem, essa é sua marca de vacina ${ }^{7}$. Só sua. Essa marca é um sinal que o indivíduo carrega no seu próprio corpo de múltiplos significados. Para alguns, garante uma dupla submissão, à norma jurídica e à autoridade sanitária. Para outros, simboliza segurança, devido à proteção preconizada pelo mundo biomédico. Ela atesta, independentemente do motivo, seja por segurança ou submissão, que aquele corpo, de alguma forma, se adequou a um tipo de regra.

Se a lógica de normalização, controle e invasão dos corpos por meio das vacinas soa como ponto negativo para alguns, por outro, segundo Cunha e Durand (2011), a vacinação "é claramente uma das políticas e uma das técnicas de segurança médica mais globalizadas, (...) ela adquiriu uma força ideológica que é difícil ficar alheio ao que ela exerce” (2001, p. 01), salvando anualmente, condizente com a Organização Mundial de Saúde (OMS, 2014), entre 2 a 3 milhões de vidas, confirmando-se uma "das intervenções de saúde pública mais eficientes e com maior êxito no mundo" (HARTMANN, 2016, p. 1).

Assim, para um historiador das ciências sociais, falar de vacinação é algo complexo (MOULIN, 2003), visto que a história das vacinas tende a ser bipartida em campos opostos, o primeiro "denunciando um empreendimento quase diabólico, enquanto que o outro se vangloria de um sucesso de facto que legitima sem apelação a totalidade do empreendimento" (2003, p. 500).

Frente a esta aparente contradição, para a Antropologia, o fenômeno vacinal se revela um campo de análise plural, pois pensa as diferentes interações entre saúde, sistema biomédico, Estado e indivíduo. "Na perspectiva de uma antropologia das vacinas é possível revelar as faces históricas, geográficas, políticas de uma história aparentemente única - a da imunização, e se interrogar a respeito da unidade das práticas humanas” (MOULIN, 2003, p. 499), que estão a se alterar e acabam por reposicionar o mundo vacinal. Segundo a autora

\footnotetext{
${ }^{7}$ A vacina referida aqui é a BCG (Bacilo Calmette-Guérin) e previne a tuberculose. Ela existe desde 1921 e faz parte do calendário oficial de vacinação. A marca é formada a partir de uma reação do nosso organismo aos componentes presentes na vacina, sinal que ela fez efeito. (PEREIRA, 2007).
} 
(2003), é preciso investigar melhor essa história triunfalista das vacinas, não pelo fato de tentar negar a força do princípio da vacinação, mas para 'reconhecer que não existe 'uma' vacinação, mas sim vacinas que apareceram em diferentes períodos (...), com objetivos diferentes, e que parece difícil definir a gênese de tal 'aventura"' (2003, p. 500), apenas com um posicionamento definido. Pensar sobre este movimento e buscar compreendê-lo, minimamente, é uma atividade desafiadora.

Propus a mim esta tarefa quanto à vacina HPV. Neste capítulo apresentarei um breve resgate histórico sobre os fatos mais relevantes dentro da longa trajetória da vacina no mundo e no Brasil. Penso ser importante contextualizar estas fases, pois é na história que a força ideológica da vacinação se fortaleceu, visto que “a imunização (...) é produto de uma trajetória histórica das políticas de saúde associadas ao processo de construção de Estado no Brasil” (HOCHMAN, 2011, p. 372). Mencionarei também as normas jurídicas e sanitárias que perpassam a vacinação, pois são muito importantes para entender o contexto sócio histórico que a vacina HPV encontrou ao ser aprovada no Brasil, posta em prática pelo Distrito Federal e, gradualmente, pelos outros estados brasileiros.

Porém, a intenção principal deste capítulo é conhecer a vacina HPV, dentre outros fatos, sua descoberta, sua disseminação pelo mundo e sua chegada ao Brasil e desdobramentos. E também, apresentar a vacina per si, no sentido de falar sobre as diretrizes e as regras recomendadas pelo mundo institucional da saúde. Todas estas frentes de conhecimento oferecem algumas indicações e base para os capítulos que se seguirão. Antes do mundo social e cultural que perpassa cada vacina, dentro de um tempo e espaço específicos, proponho que se conheça o fenômeno no modo institucionalizado.

A vacina HPV possui uma história curta quando comparada à da primeira vacina a aparecer, a vacina da varíola, datada de 1798. Porém, friso que não apresento uma linha histórica-cronológica detalhada. O lugar, resultado do processo histórico que a vacina assumiu na interface cuidado e praticas de saúde, é o objeto de interesse aqui. 


\section{A história de uma aventura vacinal}

Moulin define a vacinação como uma "aventura globalmente bem sucedida" (1996, p. 500), mas com zonas obscuras em sua história. O “apogeu” vacínico percorreu um longo caminho para se consolidar, fama esta alcançada por meio do alto patamar valorativo conferido às vacinas, por serem consideradas um dos maiores avanços na história da saúde em salvar vidas, "superior à descoberta dos antibióticos, perdendo somente para o saneamento básico e água potável” (PLOTKIN, 2008 apud BARBIERI, 2014, p. 18). A imunização por meio da vacina é uma técnica preventiva com elevada relação custo/benefício contra as doenças, o que acaba por torná-la eficaz por diversos pontos de vista, seja econômico ou biológico (Ibid., 2014).

Várias doenças ameaçaram a vida humana na história, mas uma delas é emblemática e serve para marcar de vez a ascensão da vacina. A varíola

(...) constituía verdadeiro flagelo humano, ceifando vidas ou desfigurando o rosto dos sobreviventes com cicatrizes indeléveis e perda de visão. Calcula-se que no século XVIII, houve, somente na Europa, sessenta milhões de vítimas de varíola. (REZENDE, 2009, p. 2)

Foi na busca por uma solução aos prejuízos causados por ela que se abriram as portas para o estudo de uma nova técnica que pudesse combatê-la. Técnica essa que, conforme Rezende (2009), inicialmente, remonta à antiguidade, onde os povos orientais

utilizavam há mais de mil anos a chamada "variolização", que consistia na inoculação de material retirado das pústulas de um enfermo, na pele de um indivíduo são. (2009, p. 2)

Conforme Schatzmayr (2001), este método começou a ser utilizados de forma sistemática há mais de mil anos, pelos chineses. Eles que passaram a inserir pus de feridas de pessoas com varíola em indivíduos saudáveis, com base em experiências anteriores realizadas

por hindus e egípcios. "O método tinha riscos sérios, mas a mortalidade variava de 3\% a 1\% entre as pessoas que recebiam o pus - bem menor que a letalidade da doença, que ultrapassava 
os 30\%. Esta técnica da “variolização" ganhou adeptos na Ásia, África e chegou à Europa mais tarde" (SCHATZMAYR, 2001, p. 63).

O método da variolização estendeu-se aos países do Ocidente no século XVIII, graças sobretudo à esposa do embaixador inglês em Constantinopla, Lady Montagu, famosa por sua beleza e elegância, que foram afetadas pela varíola. Em 1717 ela fez inocular seu filho de três anos de idade e, em 1721, já de volta à Inglaterra, sua filha de cinco anos. A corte real inglesa interessou-se pelo método, que passou a ser chamado de bizantino, em alusão à Bizâncio, antigo nome de Constantinopla (hoje Istambul). A variolização difundiu-se prontamente na Inglaterra e teve defensores ilustres em outros países, como Von Haller na Alemanha, Voltaire na França, e Benjamin Franklin nos Estados Unidos. (2009, p. 2)

O que cabe ao ocidente, de acordo com Rezende (2009) é de fato o incremento da técnica e sua difusão, no século XVIII, a partir dos estudos feitos pelo médico britânico Edward Jenner (1749 -1823) que, após vinte anos de coleta de material e observações, testou o uso do "vírus da varíola bovina - retirado das pústulas de vacas doentes - em camponeses ingleses, na tentativa de protegê-los desta doença. O próprio termo "vacina" originou-se desta da expressão 'vaccination', a partir do termo latim 'vacca”" (REZENDE, 2009, p. 2). Ao passar o líquido produzido em cima de machucados ou arranhões, ele conseguiu “imunizar" pessoas. Assim, oficialmente, a vacina foi descoberta, por volta do ano de 1798.

Após a vacina contra a varíola, no século XIX surge a vacina contra a raiva, descoberta por Louis Pasteur em 1885.

A descoberta foi o primeiro resultado de grande repercussão da microbiologia aplicada à medicina. Ela trouxe a consagração definitiva dos trabalhos de Pasteur e propiciou a criação, em 1888, na cidade de Paris, do Instituto que levou seu nome, um dos mais importantes centros mundiais de pesquisa científica. Este princípio da atenuação dos micro-organismos, utilizado à época, também foi usado na criação da vacina BCG (contra a Tuberculose) e a Vacina contra a Febre Amarela, no século XX e são utilizadas até hoje. (SCHATZMAYR, 2001, no, p. 67)

A partir daí deslancharam os processos de produção e investigação sobre as doenças. $\mathrm{Na}$ primeira parte do século XX, conforme Barbieri (2014) foram desenvolvidas vacinas contra: 
difteria (1923), tétano (1926), coqueluche (1926), tuberculose (BCG, em 1927) e febre amarela (1935). Já na segunda metade do século XX, além do avanço tecnológico e a busca por vacinas com alta eficácia e baixa reação, foram criadas as vacinas contra a poliomielite, sarampo, caxumba, rubéola, varicela, hepatite A e B. (2014, p. 21)

No século XXI, além da vacina contra Varicela Zoster e a HPV, estão em fase de ensaios clínicos as vacinas contra dengue, malária, herpes simples, estreptococo do grupo B, e em ensaios pré-clínicos, uma vacina contra o HIV (REZENDE, 2014).

Junto ao desenvolvimento tecnológico que marca a história da descoberta das vacinas, estão as políticas de imunização postas em prática pelos governos e pela Organização Mundial de Saúde (OMS), "que alcançaram resultados importantes, como a erradicação da varíola em todo o mundo em 1979, bem como outras como a Poliomielite em 1989, e controle de diversas doenças, como sarampo e tétano" (PLOTKIN et al, 2008 apud BARBIERI, 2009, p. 19).

No âmbito do Brasil, a vacina contra a varíola chegou em 1804. Com base em um artigo da historiadora em saúde e ciências, Arlene Gazêta (2014), esta aponta a relação que a história da saúde pública no Brasil tem com a varíola, devido o desempenho desta doença na estruturação e orientação das políticas de Estado.

A varíola foi introduzida no Brasil pelos "descobridores" europeus. Com o processo de colonização, a doença foi se disseminando. A primeira referência foi feita por José de Anchieta, em 1561, e a primeira epidemia registrada data de 1563 . A vacina chegou ao Brasil em 1804. (2014, p.2)

A chegada da corte ao Brasil, em 1808, "propiciou importantes mudanças nas instâncias sociopolíticas, econômicas e sanitárias do país. O Rio de Janeiro, sede do Império português e principal porto do país, tornou-se centro de intervenções sanitárias” (Ibid., p. 2). Devido ao forte impacto que a varíola impunha no meio imperial, o rei D. João criou a Junta Vacínica da Corte, no ano de 1811, responsável pela vacinação jenneriana - vimos antes como funcionava. Em 1822,

após a Independência, os serviços de saúde passaram a ser da competência das câmaras municipais - atendendo à proposta de descentralização do poder - que, em conjunto 
com as iniciativas particulares, estimularam a criação de instituições locais para o controle da varíola. A obrigatoriedade da vacina foi, pela primeira vez, estabelecida no município do Rio de Janeiro, em 1832, pelo Código de Posturas. A não vacinação se tornou passível de multa. Em 1846, foi criado o Instituto Vacínico do Império, órgão central que atuava nas localidades e era responsável pela vacinação na corte. Também foi estabelecida a obrigatoriedade da vacinação em crianças de até 3 meses e em grupos determinados, exigindo-se o atestado de vacinação para a admissão em algumas instituições. (GAZÊETA, 2014, p. 3)

Em meados do século XIX, algumas epidemias que assolavam a Europa, também chegaram ao país, tais como febre amarela, tuberculose e ainda a varíola, e em 1849 o governo imperial criou a Junta de Higiene, que tinha "inicialmente proposta para o controle da febre amarela, ela ampliou suas atividades, passando, em 1851, a denominar-se Junta Central de Higiene Pública” (Ibid., p. 3). Porém, isso foi insuficiente para melhorar ou mesmo alterar o alto quadro epidêmico que o Brasil se encontrava, muito mais devido à extensão do território e às más práticas de higiene da população, segundo a historiadora. Em 1886, houve a criação da Inspetoria Geral de Higiene e a vacinação antivariólica ficou sob a responsabilidade desse órgão (FERNANDES, 2009).

Porém, não houve controle da doença. Ao final do século XIX, tínhamos no Brasil o desenvolvimento (precário) urbano das capitais, o que favorecia a ocorrência de epidemias, muito mais agora com a vinda intensa de imigrantes para a agricultura cafeeira. Frente a uma epidemia de varíola que aflingia a capital do país à época, Rio de Janeiro, Oswaldo Cruz e sua comissão reinstauraram a obrigatoriedade da vacina antivariólica, o que culminou na Revolta da Vacina, em 1904.

Vários historiadores fizeram o esforço de esboçar essa campanha ${ }^{8}$ de vacinação sob outros vieses, além do biomédico e sanitário, entre eles Nicolau Sevcenko. Interessante em seu livro é o fato que o Brasil passava por uma mudança de mentalidade, "havia um extraordinário abismo entre pobres e a República, logo abria fecundas pistas de investigação sobre um mundo de valores e ideias que estava chegando" (1993, p. 31), e isso refletiria também nas mudanças

\footnotetext{
${ }^{8}$ Dá-se o nome de "campanha" a um conjunto de ações do Estado, originadas geralmente a partir de uma política pública. Em relação às vacinas, estas campanhas são colocadas em prática para controlar ou preservar o controle de uma doença. Quanto ao uso do termo no texto, este aparecerá inúmeras vezes, tanto na ótica biomédica, como indicando a apropriação dele pelos interlocutores da pesquisa.
} 
corporais (higiene) e urbanizadoras. Havia uma busca clara por outras evidências, além da biomédica, para explicar o fenômeno da vacinação.

A ideia maior, de acordo com Sevcenko (1993), é que a urbanização era necessária e o forte teor burguês da fase republicana despertaram movimentos e crises convulsivos, cuja solução foi o sacrifício de grupos populares, em virtude do bem comum. A grande metropolização que o Rio de Janeiro passou pós-monarquia, segundo Sevcenko, com a vinda de pessoas do campo, com recentes ex-escravos livres, chegada de imigrantes, entre outros, favoreceu para um quadro de pessoas amontoadas no centro da cidade, o que intensificou o quadro da marginalização, como criminalidade, prostituição, vadiagem, alcoolismo, colocando em risco certa seguridade/ordem social - cenário muito bem descrito e contextualizado por Carrara (1996), em seu livro sobre a luta contra a Sífilis no Brasil. Foi o que aconteceu na Revolta da Vacina, em 1904, que buscava o saneamento completo e a extinção das endemias da capital, por meio da remoção de cortiços, da drenagem dos mangues, da canalização dos esgotos, além da higiene e imunização dos corpos das pessoas. A promoção da salubridade aqui era abrangente.

O fato deflagrador da revolta foi a publicação da imposição obrigatória da vacinação contra a varíola, que antes era oferecida, mas na forma da procura espontânea. A vacinação era imprescindível para a saúde pública, pois, somente naquele ano, quase cinco mil pessoas já haviam morrido por causa da varíola. A compulsoriedade abriu caminho para diferentes questões preocupantes, pois, "não havia qualquer preparação psicológica da população, de quem só se exigia a submissão incondicional” (SEVCENKO, 1993, p. 18). A população foi vacinada a contragosto, sem informação, os agentes públicos invadiam as casas, tomavam os corpos, portavam um instrumento de vacina que mais parecia uma "pistola".

A explicação mais óbvia para a revolta, segundo Carvalho (1987), foi prioritariamente as razões ideológicas e morais envolvidas no processo. Sua obrigatoriedade fez com que a população se irritasse com a atuação do governo, que vistoriava e desinfetava suas casas à revelia, o que se configurou como ofensa à honra e aos corpos das mulheres da família, "nossa tese foi que este guarda chuva moral foi que tornou possível a mobilização popular de 1904 nas proporções em que se deu" (CARVALHO, 1987, p. 136). 
Conforme Sevcenko (1993), a reforma urbana não se fez somente sobre o espaço físico, mas sobre tudo o que rodeava as pessoas deslocadas, vacinadas. Foi sobre seus hábitos, família, cotidiano, cultura, enfim

tudo é atingido pela nova disciplina espacial, física, social, ética e cultural imposta pelo poder reformador. Gesto oficial, autoritário e inelutável, que se fazia ao abrigo de leis de exceção e bloqueavam quaisquer direitos e garantias das pessoas atingidas. Gesto brutal, disciplinador e discriminador, que separava claramente o espaço do privilégio, do espaço da opressão. (SEVCENKO, 1993, p. 62)

A vacinação ocorreu, salvou vidas, mas, acima de tudo, analogamente, promoveu a reurbanização da cidade, "afinal seu grande objetivo era o de exibir ao mundo desenvolvido a imagem de uma nação próspera, civilizada, ordeira e com um Estado consolidado e estável” (Ibid, p. 61). Mais também começou ali o ativismo de pacientes, a explícita demonstração de que a biomedicina/ciência não convence a todos automaticamente.

Apesar deste importante fato histórico, Hochman (2011) chama à atenção a ausência de relatos históricos parecidos com o da Revolta da Vacina no transcorrer do século XX. Hochman (2011, p.380) acredita que vários fatores contribuíram para isso, em que pesem as ações nacionais para combater a varíola, em especial nos anos 60 e 70, a introdução progressiva de novas vacinas para a população, as campanhas de vacinação muito bem articuladas (HOCHMAN, 2011 apud BARBIERI, 2014). Isto ajudou a fomentar e fortalecer uma "cultura da imunização" que, segundo ele,

é o processo de introdução de vacinas, de campanhas de vacinação e de vacinação em massa empreendidas pelo Estado brasileiro desde o final do século XIX. (...) Sustento que essa "cultura" se constituiu ao longo do século passado e se expressa pela adesão da população aos programas ${ }^{9}$ governamentais de imunização e pela demanda cada vez maior de que novas vacinas sejam oferecidas pelo poder público. (2011, p.376)

A "cultura da imunização" marca a sociedade brasileira, principalmente a partir da erradicação da varíola em 1973 no Brasil.

\footnotetext{
${ }^{9}$ Um programa de saúde é um conjunto de ações implementado por um governo com o objetivo de melhorar as condições de saúde da população.
} 
Sessenta anos depois de uma revolta contra a vacinação obrigatória, a população, em vez de fazer barricadas, não só saiu de suas casas como formou filas e aglomerou-se em praças públicas para ser vacinada entre 1967 e 1973, no período mais duro de um regime autoritário avesso a concentrações populares. Manifestou uma espécie de "civismo imunológico", parafraseando Warwick Anderson. Depois da erradicação da varíola (certificada em 1973), a sociedade continuou, além da vacinação de rotina, a participar de campanhas públicas, em particular aquelas contra a poliomielite, e mais recentemente as de sarampo, rubéola, influenza, entre outras doenças imunopreviníveis, participação atestada pelos resultados de cobertura da vacinação e do controle e mesmo a possível erradicação dessas doenças no Brasil. O sucesso da imunização certamente reforçou sua credibilidade social. (HOCHMAN, 2011, p. 376)

Este cenário de diversificação de vacinas e sucesso quanto às erradicações de doenças, somado à progressiva conquista de novas vacinas, marca o surgimento de um dos maiores programas de saúde pública do Brasil (HOCHMAN, 2011), o Programa Nacional de Imunização (PNI), criado em 1975, figurando a expressão institucional da vacinação no Brasil. "O destaque do programa deveu-se a qualidade de suas políticas, quanto à variedade de vacinas disponibilizadas e ao acesso das pessoas, colocando as vacinas de modo equânime e distributivo à população" (BARBIERI, 2014, p. 26).

A vacina e a vacinação foram tecnologias de incorporação de territórios e populações ao Estado nacional, de promoção da cidadania biomédica e da regulação da interdependência sanitária, isto é, dos efeitos negativos da doença de uns sobre terceiros. (HOCHMAN, 2011, p. 377)

Assim o PNI obteve destaque nacional, se expandiu, e também se destacou para o mundo, afinal "a cesta de vacinas disponíveis gratuitamente pelos serviços públicos de saúde é maior do que aquela recomendada pelas organizações de saúde internacionais" (HOCHMAN, 2011, p. 373). Segundo Novaes et al (2012), o programa oferece mais de 17 vacinas para crianças e adolescentes, além de diversos reforços para grávidas, adultos e idosos. Politicamente forte, o PNI é hoje parte integrante do Programa da OMS, recebendo o apoio técnico, operacional e financeiro do Fundo das Nações Unidas para a Infância (UNICEF) e também contribuições do Rotary Internacional e do Programa das Nações Unidas para o Desenvolvimento (PNUD) (BRASIL, 2013).

O PNI é uma autoridade epidemiológica brasileira que anda de mãos dadas às normas jurídicas e às autoridades sanitárias, afinal, 
Vacinas, vacinadores e campanhas de vacinação fizeram parte do longo processo de estabelecimento da autoridade sanitária no Brasil. Territórios e populações foram incorporados ao Estado nacional a partir de artefatos como agulhas, lancetas, seringas, injetores e imunizantes. (...) A agenda global de imunização, (...) e o lugar da imunização no Sistema Único de Saúde indicarão as possibilidades e os caminhos dessa “cultura da imunização". (HOCHMAN, 2011, p. 387)

Quanto ao âmbito legal, conforme Barbieri (2014), a vacinação é obrigatória no país e está prevista em lei. O Decreto n. 78.231 de 1976 foi a primeira legislação a estabelecer a obrigatoriedade das vacinas, como descrito a seguir:

Art. 27. Serão obrigatórias, em todo o território nacional, as vacinações como tal definidas pelo Ministério da Saúde, contra as doenças controláveis por essa técnica de prevenção, consideradas relevantes no quadro nosológico nacional.

Art. 29. É dever de todo cidadão submeter-se e os menores dos quais tenha a guarda ou responsabilidade, à vacinação obrigatória.

Parágrafo único. Só será dispensada da vacinação obrigatória, a pessoa que apresentar Atestado Médico de contraindicação explícita da aplicação da vacina. (BRASIL, 1976)

Ainda no âmbito legal, o Estatuto da Criança e Adolescente (ECA) - Lei Nacional de 1990 - regulamentou o artigo 227 da Constituição Federal do Brasil de 1988, o qual assegura as crianças e aos adolescentes direitos, como saúde, alimentação, moradia, por parte da família, da sociedade e do Estado. O ECA confirma estes jovens como sujeitos de direitos, em especial de serviços de saúde:

Art. 14. O Sistema Único de Saúde promoverá programas de assistência médica e odontológica para a prevenção das enfermidades que ordinariamente afetam a população infantil, e campanhas de educação sanitária para pais, educadores e alunos. $\int 1^{\underline{0}}$ É obrigatória a vacinação das crianças nos casos recomendados pelas autoridades sanitárias.

Estas leis são apenas alguns exemplos dentre tantos outros instrumentos legais que regem a vacina. Em termos práticos, as leis que contemplam a vacinação no Brasil acabam por afirmar que esta é consagrada pelo Estado como um direito a ser garantido, mas também um dever a ser seguido. Como afirma Hochman (2011), esta garantia faz com que a demanda e a 
oferta por vacinas aumente. E, por tabela, espera-se sempre mais a participação social no cumprimento do que é preconizado pelo Estado.

Quanto às normas sanitárias sobre vacinação, estas possuem maior destaque por parte da Agência Nacional de Vigilância Sanitária (ANVISA), a qual possui aparato legal, por sua vez, sendo instituída e regulamentada pela Lei Federal no 9.782 de 26 de janeiro de 1999, lei esta que define o Sistema Nacional de Vigilância Sanitária, cria a Agência Nacional de Vigilância Sanitária e dá outras providências. Outras entidades do Estado também são importantes como a FUNASA, mas não entram na análise.

Esta lei define a vigilância sanitária como um conjunto de ações capazes de "eliminar, diminuir ou prevenir riscos à saúde e de intervir nos problemas sanitários decorrentes do meio ambiente, da produção e circulação de bens e da prestação de serviços de interesse da saúde" (BRASIL, 1999). Quanto à vacinação especificamente, é ela que cuida de "todas as etapas e processos, da produção ao consumo; e o controle da prestação de serviços que se relacionam direta ou indiretamente" (BRASIL, 1999) à vacinação. Ou seja,

As ações de vigilância sanitária devem ter sempre por finalidade a proteção da saúde pública. (...) Como bem define o art. 197 da Constituição, as ações e serviços de saúde têm relevância pública, ou seja, devem ser priorizadas. E neste sentido deve-se ressaltar que os serviços públicos de saúde e a produção estatal de medicamentos, vacinas e outros produtos sob vigilância sanitária devem, igualmente, cumprir com as exigências que visam proteger a saúde. (COSTA, 2009, p. 59)

Pontualmente, Costa (2009) considera a busca pelo cuidado da vida social, construída por meio de recomendações e adoção de medidas de prevenção e controle das doenças nos corpos dos indivíduos. Estar vacinado é, acima de tudo, proteger a sociedade. A produção de medicamentos, de vacinas, de alimentos e bebidas, o controle da qualidade da água, entre outros, conforme Rosenfeld (2000), são exemplos da importância de organismos públicos de controle e vigilância, para se evitar, ao máximo, a propagação e a difusão de riscos e doenças para o corpo social, o que poria em perigo a ordem social.

Quando se fala em risco, pode-se acionar o dispositivo da interdependência social, o qual coloca, para todas as pessoas que riscos dentro de uma sociedade existem e podem “atingir e prejudicar outras pessoas ou o conjunto da sociedade, além daquelas diretamente responsáveis ou envolvidas" (BODSTEIN, 1995 apud ROSENFELD, 2000, p. 81). Ao pensar 
sobre a interdependência social, Hochman (2012) nos leva a refletir especificamente sobre as doenças e seus micro-organismos, os quais colocam "os seres humanos seriam iguais ante a ameaça de uma doença" (HOCHMAN, 2012, p. 51), onde evoca-se da cooperação de todos para conter este mal. A doença acaba por igualar os seres humanos em uma cadeia de dependência mútua,

alcançando todas as comunidades, seriam uma decorrência necessária desse infinito encadeamento de seres humanos e sociedades. Esta seria a "dimensão socialista do micróbio" (EDSON, 1895). A ação revolucionária desses seres invisíveis tornou os homens mais semelhantes, ou pelo menos igualmente mais frágeis, e os interligou em uma enorme rede de relações de interdependência (...) (HOCHMAN, 2012, p. 51)

Assim, um exemplo típico de riscos e ao mesmo tempo de interdependência são as "ocorrências de surtos de doenças infectocontagiosas, que, se não controlados, ameaçam a sobrevivência do conjunto da coletividade" (ROZENFELD, 2010, p. 84).

Diante da atuação da norma jurídica e sanitária, pode-se perceber que a vacinação não se trata apenas de uma escolha individual. Vê-se ainda uma grande e única narrativa para a história das vacinas, esta sempre em razão do progresso e pelo bem social (BARBIANI; JUNGES, 2014). Por trás desta, existem as intenções do sanitarismo e da medicalização da sociedade, atuando para colocar tudo nos "moldes da ideologia higienista cidadã" (BARBIANI; JUNGES, 2014, p.1).

Antes de encerrar, gostaria de completar este item com uma tabela sobre as vacinas no Brasil, a qual foi retirada de um material encontrado nos arquivos online do Ministério da Saúde (MS), chamada Revista da Vacina (2006). Esta revista foi lançada em comemoração aos 100 anos da Revolta da Vacina, ocorrido em 2014. Contextualizada pelo MS como um marco da saúde pública brasileira, a Revolta da Vacina espelha especialmente ações governamentais no campo social que se deram desde a introdução da vacina no Brasil. Ainda há outra utilidade nesta tabela, a de resumir os caminhos históricos percorridos até aqui (suprir alguma lacuna deixada) e observar como o fenômeno vacinal se reconfigurou e se intensificou a partir de 1975, com o PNI:

1804 Introdução da vacina no Brasil. 


\begin{tabular}{|c|c|}
\hline 1811 & Criada a Junta Vacínica da Corte. \\
\hline 1832 & $\begin{array}{l}\text { Primeira legislação de obrigatoriedade da vacina no } \\
\text { Brasil. }\end{array}$ \\
\hline 1834 & Epidemia de varíola no Rio de Janeiro. \\
\hline 1846 & $\begin{array}{l}\text { Criado o Instituto Vacínico do Império a partir da } \\
\text { reestruturação da Junta Vacínica. }\end{array}$ \\
\hline 1872 & $\begin{array}{l}\text { Nasce Oswaldo Gonçalves Cruz em São Luís de } \\
\text { Paraitinga, São Paulo. }\end{array}$ \\
\hline 1878 & Epidemia de varíola no Rio de Janeiro. \\
\hline 1886 & Extinção do Instituto Vacínico. \\
\hline 1887 & $\begin{array}{l}\text { Epidemia de varíola no Rio de Janeiro. } \\
\text { Introdução da vacina antivariólica animal no Brasil. }\end{array}$ \\
\hline 1889 & $\begin{array}{l}\text { Obrigatoriedade da vacina para crianças de até seis } \\
\text { meses de idade. }\end{array}$ \\
\hline 1894 & Criação do Instituto Vacínico Municipal. \\
\hline 1900 & $\begin{array}{l}\text { Criação do Instituto Soroterápico Federal, primeira } \\
\text { Instituição a produzir soro no Brasil. }\end{array}$ \\
\hline 1902 & $\begin{array}{l}\text { Oswaldo Cruz assume a Direção-geral do Instituto } \\
\text { Soroterápico Federal. }\end{array}$ \\
\hline 1903 & $\begin{array}{l}\text { Rodrigues Alves nomeia Oswaldo Cruz como } \\
\text { Diretor Geral de saúde pública, cargo que } \\
\text { corresponde atualmente ao de Ministro da Saúde. }\end{array}$ \\
\hline 1904 & $\begin{array}{l}\text { Epidemia de Varíola assola a capital. } \\
\text { Aprovada a lei da obrigatoriedade da vacinação. } \\
\text { Estoura a Revolta da Vacina. }\end{array}$ \\
\hline 1907 & Febre Amarela é erradicada no Rio de Janeiro. \\
\hline 1908 & $\begin{array}{l}\text { Epidemia de Varíola leva a população em massa aos } \\
\text { postos de vacinação. }\end{array}$ \\
\hline 1909 & $\begin{array}{l}\text { Oswaldo Cruz deixa a Diretoria Geral de Saúde } \\
\text { Publica, passando a dedicar-se apenas ao Instituto de } \\
\text { Manguinhos, que passa a se chamar Instituto } \\
\text { Oswaldo Cruz. }\end{array}$ \\
\hline 1917 & Morre Oswaldo Cruz \\
\hline 1919 & $\begin{array}{l}\text { O Intituto Oswaldo Cruz incorpora em sua estrutura } \\
\text { o Instituto Vacínico Municipal que passa a ser }\end{array}$ \\
\hline
\end{tabular}




\begin{tabular}{|c|c|}
\hline & denominado Instituto Vacínico Federal. \\
\hline 1921 & Regulamentação do Instituto Vacínico Federal. \\
\hline 1925 & Introduzida a BCG no Brasil. \\
\hline 1937 & $\begin{array}{l}\text { Início da produção e utilização da vacina contra a } \\
\text { febre amarela fabricada no Brasil. }\end{array}$ \\
\hline 1939 & $\begin{array}{l}\text { Discussões sobre a eficácia da vacina contra a febre } \\
\text { amarela. }\end{array}$ \\
\hline 1940 & $\begin{array}{l}\text { Reforçada a necessidade de combater o mosquito } \\
\text { vetor, aedes aegypti, devido à baixa eficácia da vacina. }\end{array}$ \\
\hline 1942 & Erradicada a febre amarela urbana no Brasil. \\
\hline 1948 & Realizado o I Congresso Mundial de BCG. \\
\hline 1953 & Epidemias de difteria no Brasil. \\
\hline 1961 & $\begin{array}{l}\text { Realizadas as primeiras campanhas com a vacina oral } \\
\text { contra a poliomielite. }\end{array}$ \\
\hline 1962 & Instituída a Campanha Nacional contra a Varíola. \\
\hline 1966 & Criada a Campanha de Erradicação da Varíola. \\
\hline 1970 & $\begin{array}{l}\text { Criada a Superintendência de Campanha de Saúde } \\
\text { Pública (SUCAM) resultado da fusão do } \\
\text { Departamento Nacional de Endemias Rurais, da } \\
\text { Campanha da Erradicação da Varíola e da } \\
\text { Erradicação da Malária. }\end{array}$ \\
\hline 1971 & $\begin{array}{l}\text { Implantado o Plano }{ }^{10} \text { Nacional de Controle da } \\
\text { Poliomielite. } \\
\text { Últimos casos de varíola no Brasil. } \\
\text { Iniciada a produção do BCG liofilizado pelo } \\
\text { Butantan. }\end{array}$ \\
\hline 1972 & Início do Programa de Vacinação Anti-sarampo. \\
\hline 1973 & $\begin{array}{l}\text { Certificação internacional da erradicação da varíola } \\
\text { no } \\
\text { Frasil. } \\
\text { comulado o o objetivo de controlar ou erradicar doenças } \\
\text { infecto-contagiosas e imunopreviníveis. }\end{array}$ \\
\hline
\end{tabular}

${ }^{10}$ De maneira geral, planos são tidos como uma forma de planejamento global sobre um assunto, os quais contêm os métodos e medidas para execução de um empreendimento. (...) Já os programas são tipos de planejamentos mais específicos, que inclui objetivo e metas concretas. Ressalto esta diferença com o intuito destes termos não passarem naturalizados e confusos ao longo da escrita. (RAMOS; SCHABBACH, 2012) 


\begin{tabular}{|c|c|}
\hline 1974 & $\begin{array}{l}\text { Criado o Programa Ampliado de Imunizações. } \\
\text { Epidemia de meningite meningocócica no Brasil. }\end{array}$ \\
\hline 1975 & $\begin{array}{l}\text { Início do sistema de registro de doses de vacinas } \\
\text { aplicadas. } \\
\text { Instituído o Sistema Nacional de Vigilância } \\
\text { Epidemiológica } \\
\text { Campanha Nacional de Vacinação contra a Meningite } \\
\text { Meningocócica. }\end{array}$ \\
\hline 1976 & $\begin{array}{l}\text { Implantado em Bio-Manguinhos, unidade da Fiocruz, } \\
\text { um centro de produção de vacinas contra a meningite } \\
\text { meningocócica A e C. }\end{array}$ \\
\hline 1977 & $\begin{array}{l}\text { Definida as vacinas obrigatórias para menores de } 1 \\
\text { ano de idade em todo o } \text { Brasil. } \\
\text { Aprovada a Caderneta de Vacinações. }\end{array}$ \\
\hline 1980 & $\begin{array}{l}\text { Extinta a obrigatoriedade da vacinação contra a } \\
\text { varíola. } \\
\text { Início dos Dias Nacionais contra a paralisia infantil } \\
\text { no Brasil. }\end{array}$ \\
\hline 1981 & $\begin{array}{l}\text { Lançada a Campanha Nacional de Conscientização } \\
\text { sobre a febre amarela. }\end{array}$ \\
\hline 1982 & $\begin{array}{l}\text { Fiocruz lança o primeiro lote da vacina brasileira } \\
\text { contra o sarampo. }\end{array}$ \\
\hline 1984 & $\begin{array}{l}\text { Iniciada em todo o país a vacinação de crianças de } 0 \text { a } \\
4 \text { anos de idade contra poliomielite, sarampo, difteria, } \\
\text { coqueluche e tétano. }\end{array}$ \\
\hline 1986 & $\begin{array}{l}\text { Criado o Zé Gotinha, personagem símbolo da } \\
\text { campanha pela erradicação da Poliomielite no Brasil. }\end{array}$ \\
\hline 1989 & Registrado o último caso de poliomielite no Brasil. \\
\hline 1990 & $\begin{array}{l}\text { Extintas a SUCAM e a FSESP, que resultam na } \\
\text { Funasa. }\end{array}$ \\
\hline 1992 & 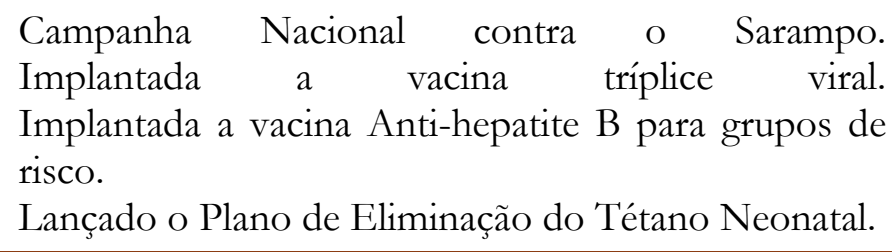 \\
\hline 1994 & $\begin{array}{l}\text { Certificação internacional da erradicação da } \\
\text { poliomielite no Brasil. }\end{array}$ \\
\hline 1996 & Campanha Nacional de Vacinação contra a Hepatite \\
\hline
\end{tabular}




\begin{tabular}{|c|c|}
\hline & B, envolvendo escolares e odontólogos. \\
\hline 1997 & $\begin{array}{l}\text { Campanha Nacional de Vacinação contra o Sarampo, } \\
\text { em crianças menores de cinco anos. }\end{array}$ \\
\hline 1998 & Vacinação contra a Hepatite B em todo o Brasil. \\
\hline 1999 & $\begin{array}{l}\text { Implementado o Plano de Erradicação do Sarampo. } \\
\text { Primeiro ano da Campanha de Vacinação para a } \\
\text { terceira idade, com a finalidade de imuniza-los contra } \\
\text { gripe, tétano e difteria. } \\
\text { Implantada a vacina contra Haemophilus influenzae } \\
\text { b, para menores de } 2 \text { anos. }\end{array}$ \\
\hline 2001 & $\begin{array}{l}\text { Intensificada a vacinação das mulheres em idade } \\
\text { fértil, com o intuito de zerar a ocorrência do tétano } \\
\text { neonatal. }\end{array}$ \\
\hline 2002 & $\begin{array}{l}\text { Implantada a vacina tetravalente (DTP }+ \text { Hib), para } \\
\text { menores de } 1 \text { ano. } \\
\text { Campanha Nacional de Vacinação contra a Rubéola } \\
\text { destinada à mulheres. }\end{array}$ \\
\hline 2003 & $\begin{array}{l}\text { Jornada Sul-Americana de Vacinação com o } \\
\text { propósito acelerar a erradicação do sarampo e o } \\
\text { controle de doenças que podem ser evitadas através } \\
\text { de } \\
\text { Assinado pelo Ministério da Saúde acordo para a } \\
\text { fabricação da vacina tríplice viral contra sarampo, } \\
\text { rubéola e caxumba. }\end{array}$ \\
\hline 2004 & $\begin{array}{l}\text { Apresentada pelo Departamento de Ciência e } \\
\text { Tecnologia (DCT) as seis vacinas prioritárias para } \\
\text { desenvolvimento nos próximos três anos: } \\
\text { pentavalente (contra difteria, coqueluche, tétano, } \\
\text { hepatite B e Haemofilus Influenzae), contra a raiva } \\
\text { humana e canina, imunização das meningites A e B, e } \\
\text { contra a leishmaniose canina. }\end{array}$ \\
\hline
\end{tabular}

Tabela 1. Dois séculos de vacinas no Brasil. Fonte: Revista da Vacina. BRASIL, 2006.

Sendo a vacina uma técnica milenar, e estando no Brasil por mais de dois séculos, percebe-se que conhecer a história ao fazer um breve resgate dos tópicos importantes é válido porque "pensar o futuro da imunização é necessariamente refletir sobre sua história". (HOCHMAN, 2011). A vacina do HPV não está na tabela, afinal, é recente e apenas aprovada 
pela Agência Nacional de Vigilância Sanitária em 2006. Entretanto, chegou o momento dela. Sigo apresentando o HPV e sua vacina.

\section{O micróbio ${ }^{11}$ HPV no mundo}

Atingindo mais de 630 milhões de homens e mulheres em todo mundo, e já sendo conhecido como a epidemia do século XXI, o Papiloma Vírus Humano vive na pele e nas mucosas genitais humanas (...) sendo responsável por $95 \%$ dos casos de câncer de colo de útero. (MARTINS, 2015, grifo nosso)

A gravidade da doença e o crescente número de casos de câncer de colo do útero ${ }^{12}$ configuram o HPV como uma preocupação mundial. Segundo o Instituto Nacional de Câncer (2011), estima-se que entre $25 \%$ e $50 \%$ da população feminina e $50 \%$ da população masculina mundial esteja infectada pelo vírus Papiloma Vírus Humano, por isso uma epidemia é reconhecida.

O HPV são vírus capazes de infectar a pele ou as mucosas (INCA, 2011). Existem mais de 150 tipos diferentes de HPV, sendo que cerca de 40 tipos podem infectar e serem prejudiciais ao trato anal e genital. Deste grupo,

Aproximadamente 15 deles são classificados como de alto risco oncogênico, pois estão associados a cânceres malignos do trato genital e não genital. Os subtipos 16 e 18 são responsáveis por 70\% a 80\% dos casos de câncer de colo do útero. (BRASIL, 2013, p. 6).

\footnotetext{
${ }^{11}$ Utilizo a palavra micróbio em alusão à ideia de "dimensão socialista do micróbio", de Hochman, considerando o HPV como mais uma doença que aciona a fragilidade humana e pede por um trabalho conjunto de combate. Ainda, com a autorização dos biólogos, uso a palavra "micróbio" como categoria para micro-organismos. Em pesquisas realizadas, descobri que o vírus do HPV não é um micróbio propriamente dito, visto que estes são considerados seres vivos, como protozoários, fungos e bactérias. Já os vírus não pertencem a esse grupo, pois não constituem uma célula. (MACHADO et al, 2004)

${ }^{12}$ É um tumor que se desenvolve a partir de alterações no colo do útero, que se localiza no fundo da vagina. As lesões precursoras ou o câncer em estágio inicial não apresentam sinais ou sintomas, mas conforme a doença avança podem aparecer sangramento vaginal, corrimento e dor, nem sempre nessa ordem. (INCA, 2011)
} 
A transmissão deste vírus se dá principalmente por via sexual, e conforme o INCA (2011), aproximadamente 75\% dos indivíduos que iniciam a vida sexual tornam-se infectados em algum momento da vida. Vale lembrar também que a infecção pelo HPV também pode ocorrer durante o parto ou, ainda, por meio de instrumentos ginecológicos não esterilizados (BRASIL, 2013). Além do HPV, dados do Relatório de Recomendação da Comissão Nacional de Incorporação de Tecnologias no SUS (CONITEC) afirmam que outros fatores que podem estar associados à presença de lesões cancerosas e, por conseguinte, desenvolver o câncer de colo do útero:

Início precoce da atividade sexual, promiscuidade do parceiro, sexo anal, múltiplos parceiros, precocidade da idade materna no primeiro parto, fumo, uso a longo prazo de contraceptivos hormonais, co-infecção por vírus Herpes simplex e fatores relacionados à dieta. (CIAPPONI et al apud BRASIL, 2013, p. 7)

A vigilância sob a vida sexual mostra-se um item importante quanto à prevenção do HPV e reverbera na vacinação, entretanto, este é um assunto reservado ao capítulo quatro. Uma vez infectada/o pelo vírus, esta costuma transcorrer sem sintomas e regredir espontaneamente, sem tratamento, na maioria dos casos, "ao menos $80 \%$ delas regridem sem intervenções” (BRASIL, 2013, p. 8). Mas, em outros casos não. O HPV pode gerar câncer, sendo sua associação mais comum à 90\% dos casos de câncer anal, 71\% de câncer de vulva, de vagina e de pênis, e 72\% dos cânceres de faringe, 95\% do câncer de colo de útero (BRASIL, 2013):

O câncer de colo do útero é o terceiro tipo de câncer mais comum entre as mulheres no mundo, e o segundo no Brasil, atrás apenas do câncer de mama. Para o ano de 2012, o Instituto Nacional de Câncer/INCA estimou a ocorrência de 17.540 casos novos de câncer de colo do útero, com risco estimado de 17 casos a cada 100 mil mulheres. (BRASIL, 2013, p. 7)

Conhece-se o vírus desde 1970. Entretanto, a relação entre o vírus HPV e o câncer de colo de útero foi descoberta apenas em 1983, após anos de estudos com exames e biópsias de cânceres diversos (NAKAGAWA, 2010). Foi o cientista alemão Harald zur Hausen, do Centro de Pesquisa em Câncer de Heidelberg, na Alemanha, o responsável por mostrar que o HPV é capaz de causar câncer no trato genital feminino. O pesquisador alemão "também identificou 
as variantes de HPV que são mais prejudiciais - os tipos 16 e 18” (INCA, 2011), informações estas que serviram para ampliar o estudo sobre este tipo de câncer e abrir as possibilidades para a fabricação de uma vacina. Por este feito, a ele foi concedido o prêmio Nobel de Medicina do ano de 2008 (LEITE NET'TO, 2010).

Desde a descoberta, em 1983, até a produção da vacina contra o vírus, foram mais de vinte anos de estudos e pesquisas, pois a vacina foi criada em 2006, na Austrália e rapidamente se expandiu pelo mundo, sendo

utilizada como estratégia de saúde pública em mais de 50 países, por meio de programas nacionais de imunização. Estimativas indicam que, até 2013, foram aplicadas cerca de 175 milhões de doses em todo o mundo. A sua segurança é reforçada pelo Conselho Consultivo Global sobre Segurança de Vacinas da Organização Mundial de Saúde. (BRASIL, 2014)

Conforme Novaes et al (2012) é importante diferenciar os dois tipos de vacina contra o HPV, uma contra quatro tipos de vírus, que é a quadrivalente, conhecida como Gardasil, e a outra, que protege contra dois tipos de vírus, chamada Cervarix:

As duas vacinas contra HPV disponíveis no mercado (Gardasil-Merck, quadrivalente, tipos 6, 11, 16 e 18 e Cervarix-Glaxo, bivalente, tipos 16 e 18) são profiláticas (previnem a infecção em quem não teve ainda contato com o vírus) e foram desenvolvidas com utilização de tecnologia genéticas complexas. (...) A produção da vacina HPV se iniciou em 1993, os primeiros resultados (...) de segurança e eficácia, foram apresentados em 2002, os primeiros resultados de eficácia clínica, em 2004 e a aprovação da vacina Gardasil pelo FDA ${ }^{13}$ ocorreu em 2006 e da vacina Cervarix em 2008. (2012, p. 2)

Fala-se em vacina profilática (preventiva) por ela ter melhores resultados de proteção em pessoas que ainda não tiveram contato com o vírus, pois a vacina "tem como objetivo evitar a infecção pelos tipos de HPV nelas contidos. Nenhuma das vacinas é terapêutica, ou seja, não há eficácia contra infecções ou lesões já existentes” (INCA, 2011). Isto recorda

\footnotetext{
13 Também conhecido como Federal Drug Administration, o FDA é o órgão governamental dos EUA que faz o controle dos alimentos (tanto humano como animal), suplementos alimentares, medicamentos (humano e animal), cosméticos, equipamentos médicos, materiais biológicos e produtos derivados do sangue humano. (NOVAES et al, 2012, p. 89).
} 
(NOVAES et al, 2012) que a vacina HPV não exclui outras ações e exames de saúde, os quais são importantes para a prevenção do câncer de colo de útero, tais como o uso do preservativo e a realização do exame Papanicolau ${ }^{14}$, o qual " é o rastreamento de células cancerosas por meio do exame citopatológico realizado nas mulheres" (2012, p. 52).

O México foi o primeiro país a adotar a vacina, em 2009, segundo Segatto (2014). Depois vieram Colômbia, Canadá e Suíça, sendo que "atualmente, a vacina foi introduzida total ou parcialmente em mais de 30 países, a maioria países desenvolvidos" (NOVAES et al, 2012, p. 6). Em alguns deles

foram destinados recursos públicos para sua incorporação na rotina dos programas de imunização (Dinamarca, Irlanda, Itália, Holanda, Noruega, Espanha, Suíça, Reino Unido, Austrália), em outros dependem de reembolso (Bonanni, 2011). Em alguns países foram também implementadas políticas para o fortalecimento dos programas de rastreamento, complemento indispensável para o alcance da efetividade pretendida para a vacina (Koulova, 2008). Nas Américas, até 2010, quatro países (Estados Unidos, Canadá, México e Panamá) a haviam implementado a vacina, mas em 2011 outros países aprovaram a sua incorporação (Argentina, Guiana, Peru e Suriname) (MMWR, 2011). A vacina selecionada [Gardasil ou Cervarix] nos diferentes países foi variável, mas as razões para a decisão final por uma ou outra não foram tornadas públicas (2012, p. 50).

O caso da Austrália é interessante, segundo Novaes (2012). O país foi o primeiro a introduzir o estudo de custo/efetividade como uma etapa importante para a incorporação desta tecnologia em saúde, a vacina HPV, no entanto, por meio de estudo realizado posicionou-se pela não recomendação da incorporação da vacina pelas autoridades sanitárias australianas. Apenas após forte mobilização política de diferentes segmentos da sociedade a vacina foi incorporada (ROUGHEAD, 2008 apud NOVAES et al, 2012, p. 51). Aponta Novaes (2012) que este perfil de não recomendação da vacina foi uma exceção, diferentemente em outros países, que rapidamente fizeram por aprovar e adotar a vacina rapidamente.

Em contrapartida, vale ressaltar que a adesão à vacina possui especificidades em relação a cada país que a adota, como foi o caso da Austrália, ou mesmo Canadá, onde cada província

\footnotetext{
14 Também chamado "preventivo" ou "prevenção", este exame "permite detectar alterações da cérvice uterina, a partir de células descamadas do epitélio e se constitui até hoje, o método mais indicado para o rastreamento do CCU por ser um exame rápido e indolor, de fácil execução, realizado em nível ambulatorial, que tem se mostrado efetivo e eficiente para aplicação coletiva, além de ser de baixo custo” (FERNANDES et al, 2009, p. 852).
} 
decidiu autonomamente pela compra da vacina, ainda conforme Novaes (2012). Esta autora ainda afirma que em países com menor renda,

os desafios para a incorporação da vacina mostram-se grandes, pois, além da garantia da existência de recursos sustentáveis para a compra da vacina, há a necessidade do fortalecimento de programas importantes dos sistemas de saúde - programa de imunização nacional, de atenção à família, ao adolescente e de atenção à mulher e o rastreamento -, ao mesmo tempo que devem continuar sendo atendidas todas as demais prioridades em saúde (Biellik, 2009, Andrus, 2008, Yothamasut, 2010, Kim, 2011), o que requer estratégias de análises comparativas de decisão complexas quanto ao uso de recursos financeiros e humanos. (NOVAES et al, 2012, p. 51)

Com estes exemplos, percebe-se que para cada país que a vacina foi adotada, cabe um estudo a parte sobre seus efeitos e desdobramentos, tanto acerca das políticas de saúde quanto do posicionamento social. Em especial, quanto à aceitabilidade e adesão à vacinação contra $\mathrm{HPV}$, pois isto apresenta desafios específicos, que no geral podem ser quanto:

1) fatores individuais - aceitabilidade dos pais e dos próprios indivíduos vinculada a valores, crenças, incertezas, confiança e informação sobre a epidemiologia do HPV, do câncer e da vacina e condições de acesso; 2) fatores sociais - atitudes dos profissionais, da saúde, fatores organizacionais, comunitários, econômicos e sociais (Fernández, 2010; Brewer, 2007; Winkler, 2008, Marc, 2010, Gefenaite, 2012 apud NOVAES et al, 2012, p. 52)

Por enquanto, me reservo a não adentrar tantos nestes desafios, pois quero trabalhá-lo na ótica da vacinação brasileira.

\section{O micróbio HPV no Brasil}

A presidenta da República, Dilma Rousseff, e o ministro da Saúde, Arthur Chioro, participaram nesta segunda-feira (10), em São Paulo, da cerimônia de lançamento da vacinação contra HPV, que será realizada nos postos de saúde e em escolas públicas e privadas de todo o país. A meta do Ministério da Saúde é vacinar $80 \%$ do público-alvo, formado por 5,2 milhões de meninas de 11 a 13 anos, em 2014. Durante a cerimônia, que aconteceu no Centro de Ensino Unificado Professora Elisabeth Gaspar Tunala, Butantã, a presidente Dilma Rousseff ressaltou a importância da vacinação, lembrando 
que vírus HPV é a principal causa do câncer do colo de útero, terceiro tipo mais frequente entre as mulheres. "Hoje estamos adotando uma medida de saúde pública para garantir às meninas uma vida saudável. Cada menina tem sua individualidade, mas é obrigação do Estado proteger todas elas", afirmou a presidenta. A presidenta Dilma também destacou a importância da parceria entre o Ministério da Saúde e o Instituto Butantan para o desenvolvimento da vacina. "Esta parceria, além de garantir proteção à saúde das meninas, assegura o emprego de muitos brasileiros", observou a presidenta. (AMÉRICO, 2014)

Recentemente, sob a tutela do Estado, com marcada incidência frente a outros tipos de câncer, o câncer de colo de útero é uma preocupação para as autoridades biomédicas e para as políticas em saúde do Brasil. E, ao ser o responsável principal por isso, o HPV figura-se em destaque. Diante de um número que não parava de crescer, o Estado Brasileiro reconheceu a necessidade de um programa de âmbito nacional para o controle do câncer do colo do útero. E em 1995,

uma equipe de técnicos do Ministério da Saúde, em parceria com organismos nacionais e internacionais, elaborou um estudo piloto que subsidiou a elaboração do Programa Nacional de Controle do Câncer do Colo do Útero. O projeto-piloto, denominado Viva Mulher, foi implantado entre janeiro de 1997 e junho de 1998 em seis localidades (Curitiba, Brasília, Recife, Rio de Janeiro, Belém e estado de Sergipe) e atendeu 124.440 mulheres, priorizando mulheres entre 35 e 49 anos que nunca haviam feito o exame preventivo ou que estavam sem fazê-lo há mais de três anos. Em 1998, o Ministério da Saúde instituiu o Programa Nacional de Combate ao Câncer de Colo do Útero. (...) De 1999 a 2001, as ações pela oferta de serviços foram ampliadas, resultando na realização de 8 milhões de exames citopatológicos por anos. (...) Em 2005, o Ministério da Saúde lançou a Política Nacional de Atenção Oncológica, que estabeleceu o controle dos cânceres do colo do útero e de mama. (...) A importância da detecção precoce dessas neoplasias foi reafirmada no Pacto pela Saúde, em 2006, por meio da inclusão de indicadores e metas a serem atingidos nos estados e municípios visando à melhoria do desempenho das ações prioritárias da agenda sanitária nacional. (INCA, 2011)

Este tipo de câncer ganhou notoriedade a partir de um levantamento de dados sobre incidências de vários tipos câncer fornecidos pelos Registros de Câncer de Base Populacional (RCBP) e do Sistema de Informação de Mortalidade, os quais permitem uma apreciação detalhada de tipos e casos de câncer por espaços geográficos do Brasil, dentre as unidades 
federativas e capitais (AYRES e AZEVEDO E SILVA, 2010 apud NOVAES et al, 2012, p.95).

O câncer de colo uterino (CCU) é a segunda causa de morte por câncer entre mulheres no mundo, com maior incidência nos países em desenvolvimento. No Brasil, representa o terceiro mais comum tipo de neoplasia maligna que acomete mulheres, depois do câncer de pele não-melanoma e do câncer de mama. As taxas de incidência do câncer de colo de útero, por 100.000 mulheres, estimada para o ano de 2008, foi de 19,18 para o País; 17,58 para a Região Nordeste e de 15,8 para o estado do Rio Grande do Norte. (FERNANDES et al, 2009, p. 851)

Observa-se essa tendência na tabela abaixo, referente aos casos de câncer no ano de 2008:

\begin{tabular}{|l|l|l|l|}
\hline \multirow{2}{*}{ Localização Primária (corpo) } & \multicolumn{3}{l|}{ Estimativa de casos novos } \\
\cline { 3 - 4 } & Masculino & Feminino & Total \\
\hline Próstata & 49.530 & - & 49.530 \\
\hline Mama Feminina & - & 49.400 & 49.400 \\
\hline Traquéia, Brônquio e Pulmão & 17.810 & 9.460 & 27.270 \\
\hline Cólon e Reto & 12.490 & 14.500 & 26.990 \\
\hline Estômago & 14.080 & 7.720 & 21.800 \\
\hline Colo do Útero & - & 18.680 & 18.680 \\
\hline Cavidade Oral & 10.380 & 3.780 & 14.160 \\
\hline Esôfago & 7.900 & 2.650 & 10.550 \\
\hline Leucemias & 5.220 & 4.320 & 9.540 \\
\hline Pele Melanoma & 2.950 & 2.970 & 5.920 \\
\hline Outras Localizações & 55.610 & 62.270 & 117.880 \\
\hline Subtotal & 175.970 & 175.750 & 351.720 \\
\hline Pele Não-Melanoma & 55.890 & 59.120 & 115.010 \\
\hline Todas as neoplasias & 231.860 & 234.870 & 466.730 \\
\hline
\end{tabular}

Tabela 2 - Tabela de distribuição de casos de câncer de acordo com o tipo (INCA, 2008)

De todo modo, parecem existir bons programas de ação contra o câncer de colo de útero, entretanto a prática nas unidades médicas não acompanha tais evoluções. Embora a existência do exame preventivo - Papanicolau, tecnologia introduzida no Brasil na década de 40 (BRASIL, 2011) - que é a estratégia utilizada oficialmente pelo MS para a detecção do 
câncer do colo do útero (BRASIL, 2011), este ainda não atingiu o público feminino como preconizado, por diversos motivos:

Estimativas indicam que cerca de $40 \%$ das mulheres brasileiras (de todas as idades) nunca fizeram o exame. Dentre as razões para esta baixa adesão estão: a dificuldade em acessar os serviços de saúde, a natureza do exame que envolve a exposição da genitália, motivo de desconforto emocional para algumas mulheres, em virtude de pudores e tabus, além das condições socioeconômicas e da falta de conhecimento sobre o câncer ginecológico. A realização do exame citopatológico tem se confrontado, na prática, com algumas barreiras presentes nos mais diversos aspectos da vida da mulher, dificultando o alcance da cobertura desejada. (FERNANDES, 2009, p. 561)

Diante da contradição entre o fortalecimento da agenda de políticas públicas em saúde acerca da prevenção do câncer de colo de útero e, por outro lado, do aumento dos números de câncer de colo de útero e da baixa procura pelo exame Papanicolau, a vacina HPV é adotada no país. Ela se mostrou um artefato tecnológico e de inovação para a saúde pública, em especial, dentro de um país onde há um dos maiores programas de vacina do mundo, o PNI, junto a uma forte cultura da imunização. A campanha de vacinação contra o HPV é mais uma estratégia de enfrentamento ao câncer de colo de útero e pareceu já nascer voltada ao público feminino, esquecendo-se dos outros tipos de câncer que este acomete, como o de pênis e o de garganta.

A vacina adotada no Brasil pela rede pública de saúde é a quadrivalente ${ }^{15}$, a Gardasil. Segundo o INCA (2011), o desenho da campanha contra o HPV indicava a vacina, inicialmente, para meninas de 11 a 13 anos. Entretanto, este recorte etário foi alterado, visto que em 2015, passou a ser de 9 a 13 anos. Para as adolescentes e jovens vivendo com HIV, a faixa etária limite se estende até os 26 anos. As meninas indígenas também estão englobadas na vacinação, com a mesma faixa etária (9-13), tendo a inclusão recente da vacina do HPV em seu calendário vacinal por meio da Portaria n. 1.498, de 19 de julho de 2013. Entretanto, embora considerando que as políticas de saúde indígena são tratadas como políticas diferenciadas, a estratégia de imunização foi a mesma. Inclusive, em abril de 2016, todos os Distritos Sanitários Especiais Indígenas (DSEIs) do país receberam uma intensa campanha de imunização que visava vacinar 120 mil indígenas, em especial, contra o HPV. As doses à época eram três: a

\footnotetext{
${ }^{15}$ Formulada para combater os quatro tipos de vírus que mais causam câncer de colo de útero.
} 
primeira dose, outra depois de seis meses, e última, depois de cinco anos (BRASIL, 2013). Como aponta Segatto (2014) esta opção pelas doses não foi uma escolha brasileira "Outros países adotaram o mesmo esquema. A Organização Panamericana de Saúde (OPAS) concluiu que há evidências favoráveis suficientes para que esse esquema seja testado pelos governos” (2014, p. 1).

Liberada para comercialização no Brasil pela Agência Nacional de Vigilância Sanitária (ANVISA), em agosto de 2006, rapidamente a demanda pela inclusão desta no calendário de imunização oficial brasileiro se fez sentir, então

foram implementadas várias iniciativas oficiais para tratar da questão. Já em dezembro de 2006 o Ministério da Saúde criou grupo de trabalho especial, com representantes de diferentes áreas, para assessorar as decisões sobre a incorporação da vacinação contra o HPV no SUS e em abril de 2007 foram divulgadas as recomendações desse grupo. (NOVAES et al, 2012, p. 17)

A partir de 2007, os laboratórios particulares, após aprovação da ANVISA e recomendação governamental, logo começaram a oferecer a vacina para quem pudesse pagar, pois os valores eram altos, contabilizados a um custo total frequentemente acima de mil reais as doses (NOVAES et al, 2012, p. 35).

Entretanto, para o setor público, a vacina HPV ainda não tinha sido adotada como uma política pública de saúde. "Até o final do ano de 2008, a vacina foi objeto de criteriosas e cuidadosas de ações técnicas e políticas por parte do Ministério da Saúde para que pudesse fazer parte do PNI” (NOVAES et al, 2012, p. 20). E isto se estendeu por mais três anos, confirmando a existência de lacunas no conhecimento que somaram contra a incorporação da vacina. Porém, a partir de 2011, segundo Eluf Neto (2011), a adesão na rede pública foi acontecendo timidamente. A primeira cidade brasileira a oferecer a vacina pela rede pública foi Campo dos Goytacazes, no Rio de Janeiro, em 2012. O jornal local destacou:

De volta às aulas, centenas de alunos de mais dez escolas da rede pública e particular de educação serão contemplados com a vacina contra o vírus do papiloma humano (HPV). Meninos e meninas serão vacinados por meio do Programa Saúde na Escola (PSE) em suas próprias unidades de ensino. (...) Campos foi uma das primeiras cidades do país a implantar a vacina, de graça, no Programa Municipal de Imunização. Somente em março de 2014, a vacina contra HPV foi disponibilizada gratuitamente nos postos de saúde do Brasil pelo Governo Federal, mas só para as garotas. Por aqui, 
a vacina está incorporada no Programa Municipal de Imunização desde 2010. (UHL, 2016, p. 1)

Campo dos Goytacazes, além de se antecipar ao resto do país quanto à vacinação, ainda incluiu os meninos, contradizendo as premissas oficiais da campanha do HPV, que atenderia somente garotas de 9 a 13 anos. Esta ação vai ao encontro do que é preconizado pelo atual Diretor do INCA, Luiz Antonio Santini, no caso do HPV, acredita ele, ser necessária a vacinação de amplos segmentos da sociedade, visto haver "a necessidade de que toda a população masculina também fosse vacinada [pela rede pública], já que os homens constituem o reservatório primário do vírus e fonte da reinfecção contínua das mulheres” (INCA, 2012, p. 2).

Assim, aos poucos, a adesão à vacina foi acontecendo nos estados brasileiros. Em 2014 ela entrou de fato para o Calendário Nacional de Vacinação e, portanto, está disponível nas ações de rotina das Unidades Básicas de Saúde para as adolescentes (sexo feminino apenas) incluídas na faixa etária preconizada. Esta vacina se mostra, então, nacional, institucionalizada, multiétnica, tendo, em 2014, atingido quase quatro milhões de meninas vacinadas com a primeira dose,

No primeiro mês de vacinação contra HPV, período em que o foco da mobilização foi nas escolas públicas e privadas de todo o País, mais de 3,4 milhões de meninas já foram imunizadas contra o vírus. O número representa $83 \%$ da meta do Ministério da Saúde, que é vacinar 4,1 milhões de adolescentes na faixa etária de 11 a 13 anos, até o final do ano. (BRASIL, 2014)

Em muitos estados brasileiros, como no DF, a vacinação está acontecendo dentro das escolas - ou aconteceu e, posteriormente, voltou para o centro de saúde. É importante informar que a vacinação nas escolas é uma estratégia adicional que contribui para o alcance e adesão do público alvo para a vacinação, segundo o PNI (NOVAES et al, 2012).

Ainda em 2014, para a produção da vacina contra o HPV, o ministério da saúde firmou pareceria entre o Instituto Butantã e o laboratório privado Merck Sharp \& Dohme para a transferência de tecnologia e desenvolvimento da vacina no país (BRASIL, 2014). Entretanto, “o Ministério da Saúde comprará da empresa 41 milhões de doses da vacina durante cinco anos - período necessário para a total transferência de tecnologia ao laboratório brasileiro, só 
depois ela será fabricada pelo Instituto Butantã, em São Paulo” (p. 2). Condizente com o Ministério da Saúde, no futuro isto trará um economia monetária muito maior do que o dinheiro que foi investido.

Esta parceria reflete as estratégias do trabalho do PNI e do estado brasileiro, visto Gadelha e Azevedo (2003), pois o governo "tratou de formar estoques desses produtos, fosse mediante a compra de produtores externos, fosse por meio da montagem de um parque produtivo próprio, instituído, desde meados da década de 1980, a partir de vários institutos públicos” (p. 699), como Butantã e Bio-Manguinhos. Porém, não obstante os êxitos alcançados pelo PNI, suas parcerias e seus institutos, o programa de imunização ainda se ressente da dependência de importações de produtos essenciais, seja na forma de produtos finais ou de concentrados de antígenos virais ou bacterianos, que são as "matérias-primas" vacinais. Aqui temos parâmetros para pensar a vacina como uma "das políticas mais globalizadas do planeta" (CUNHA; YVES-DURAND, 2011, p. 369), pois a vacina é resultado da integração (política ou técnica) entre as diferentes localidades do planeta.

Quando se fala em adesão a uma política vacinal, deve-se pensar, para além de tudo já listado, que existe a incorporação e a transferência de tecnologia para a produção desta vacina. Trazer tecnologia para um país implica a ideia de fortalecimento da indústria nacional, e geralmente são estratégias de governo quanto ao desenvolvimento econômico também, como bem apontou a presidenta Dilma Rousseff, em sua fala sobre empregos e indústrias, na abertura desta seção.

Algumas mudanças importantes aconteceram em relação a administração da vacina em 2016. A vacina Gardasil passou a ser administradas em duas doses ${ }^{16}$, e mais, o tempo entre elas foi diminuído - toma-se a primeira dose e depois de seis meses, a outra.

A vacina contra o papiloma vírus humano (HPV) vai passar a ter apenas duas doses, em vez de três, para meninas entre 9 e 11 anos. Esta é uma das mudanças anunciadas pelo Ministério da Saúde no calendário de vacinação da rede pública, que já estão valendo. Segundo a pasta, estudos recentes mostram que a resposta de anticorpos com duas doses não é inferior à aplicação de três. Já as mulheres entre 9 e 26 anos que têm

\footnotetext{
${ }^{16}$ Mudança ocorrida em janeiro de 2016, decisão do Ministério da Saúde. Antes, as doses eram três, sendo que o intervalo era de 30 dias para a segunda e 6 meses para a terceira. A mudança ocorreu devido os estudos recentes mostrarem que a resposta de anticorpos com duas doses é suficiente para a imunização. Entretanto, as mulheres entre 9 e 26 anos, com HIV, devem continuar recebendo o esquema de três doses. (LEAL, 2016)
} 
HIV devem continuar recebendo o esquema de três doses da vacina contra o HPV. (CORREIOWEB, 05 de janeiro de 2016)

Com o intuito de acompanhar a quantidade de garotas vacinadas com primeira e com a segunda dose da vacina HPV e o sucesso de seu empreendimento vacinal, foi disponibilizado no site do Ministério da Saúde, na área do Sistema de Informação do Programa Nacional de Imunizações (SI-PNI), um "vacinômetro", conforme adotado nas outras campanhas de vacinação. Este medidor indica a evolução da cobertura vacinal desde o ano de 2014, para a primeira e segunda doses da vacina contra o HPV, sendo zerado todo início de ano. Para que esse sistema de acompanhamento funcione é necessário que as informações vacinais de cada município sejam transmitidas mensalmente e com fidelidade para suas entidades epidemiológicas para fins de controle e contagem, afinal, sucessos na saúde quase sempre vêm acompanhados de números. Neste instante ${ }^{17}$, ele conta 1.404.269 doses aplicadas em 2016 em todo país e para diferentes faixas etárias.

\section{O HPV e o DF}

O Distrito Federal foi um dos pioneiros no Brasil na vacinação do HPV, atuando desde o ano de 2013. Foi o primeiro ente federativo na região Centro Oeste a adotar a vacina, chegando ao índice de $92 \%$ de corpos femininos vacinados com a primeira dose, em 2013 (DF, 2013). No âmbito do DF, a vacinação contra o HPV foi desenhada para ocorrer dentro das escolas, públicas e privadas, contando com a parceria entre a Secretaria de Educação e a Secretaria de Saúde. Tais instruções sobre como ocorreria à vacinação foram regulamentadas por meio de uma nota técnica ${ }^{18}$ publicada no Diário Oficial do Distrito Federal e disponível no site da Secretaria de Saúde do DF:

\footnotetext{
17 Verificação realizada em 16 de novembro de 2016.

18 Uma nota técnica (NT) é um documento com a fundamentação legal, institucional e histórica sobre determinada política pública, projeto de lei ou outro objeto de interesse da equipe que a formula. Nela, são apresentados os possíveis entraves e as propostas de soluções a problemas relacionados ao tema central da NT. Em geral, é acompanhada de dados estatísticos, estudos de caso, jurisprudência e outras informações complementares e necessárias à sustentação do argumento utilizado ao longo da análise. (BRASIL, 2016)
} 
Considerando as informações pertinentes a vacinação contra o papilomavírus humano (HPV) no calendário de vacinação na rotina para meninas adolescentes no Distrito Federal no ano de sua implantação (2013), informamos que:

1. No Dia Internacional da Mulher 08/03/2013 será realizado o lançamento da vacinação contra o HPV em meninas do Centro de Ensino Fundamental no. 1 da Estrutural;

2. A partir de $1^{\circ}$ de abril a vacinação será realizada em todas as Escolas públicas e privadas do Distrito Federal;

3. Serão vacinadas meninas nascidas em 2000, 2001 e 2002. Esta faixa etária foi definida após análise das recomendações da Organização Mundial de Saúde (OMS), Federação Brasileira de Ginecologia e Obstetrícia e a Sociedade Brasileira de Imunização;

4. Para garantir a efetividade da vacina quadrivalente contra o $\operatorname{HPV}(6,11,16$ e 18), são necessárias a aplicação de três doses, com intervalo de 60 e 180 dias após a primeira dose;

5. O objetivo da vacinação é prevenir a ocorrência de câncer do colo do útero, vulvar e vaginal, lesões pré-cancerosas ou displásicas, verrugas genitais e infecções causadas pelo HPV em meninas matriculadas em escolas públicas e privadas do Distrito Federal; 6. A meta é vacinar $100 \%$ dessas meninas nas escolas;

7. O calendário de vacinação respeitará o calendário escolar das escolas públicas e

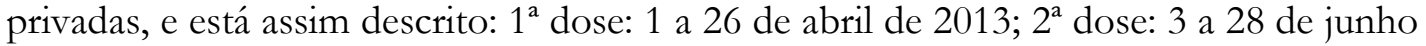
de 2013; $3^{\text {a }}$ dose: 30 de setembro a $1^{\circ}$ de novembro de 2013;

8. Desde 2006 a vacina quadrivalente contra o HPV foi considerada eficaz e segura pela OMS, e no Brasil, com mais de 30.000 doses realizadas, não houve nenhum evento adverso grave associado diretamente à vacina, segundo dados da Agencia Nacional de Vigilância Sanitária (ANVISA);

9. A vacina representa uma estratégia complementar, e não substitutiva, ao programa de rastreamento do Câncer de Colo do Útero;

10. A vacina é gratuita para as meninas, alvos desta campanha. (DF, 2013)

A nota trata de questões diversas, como faixa etária, datas e metas de vacinação, segurança da vacina, objetivos e doses. Chama a atenção o fato desta reafirmar algumas regulamentações já preconizadas, como por exemplo, a vacina voltar-se apenas ao público feminino, ficando nítido isso especialmente quanto ao dia escolhido para seu lançamento - Dia Internacional da Mulher, 08 de março. Ou mesmo afirmando seu caráter complementar no rastreamento do câncer de colo de útero, focando-se assim na necessitando do exame Papanicolau. A tríade entre rastreamento (Papanicolau), vigilância sexual (camisinha) e na imunização (vacina) do corpo feminino marcou a campanha do HPV no âmbito distrital.

Este bom compilado técnico de regras, a parceria entre as secretarias e a alta cobertura vacinal deram ao DF destaque na vacinação do HPV, cujo procedimento tornou-se referência para o Ministério da Saúde, 
A campanha de vacinação contra o HPV, promovida pela Secretaria de Saúde do DF, foi reconhecida como uma experiência de sucesso pelo Ministério da Saúde, que resolveu torná-la modelo em todo o país. A meta alcançada pelo GDF para 2013 foi a vacinação de 62,8 mil estudantes do Distrito Federal nascidas entre 2000 e 2002. Ação pioneira em todo o Brasil, segundo a Secretaria de Saúde, a imunização das meninas teve investimento do governo local de $\mathrm{R} \$ 14$ milhões, o que possibilitou a aquisição de 192 mil doses. Cada unidade custou $\mathrm{R} \$ 73$ aos cofres públicos. O enfrentamento à doença realizado pelo GDF contou com uma parceria das secretarias de Saúde e Educação. Nessa última pasta, houve a capacitação dos profissionais para esclarecerem aos pais e familiares das estudantes sobre a importância dessa vacinação. Para a subsecretária de Vigilância à Saúde, Marília Coelho, a introdução dessa nova vacina é um dos projetos mais importantes do GDF nos últimos tempos, uma vez que o impacto desse investimento será sentido na redução de casos de HPV. (BÓRIS, 2014)

Como modelo nacional, o DF incluiu em seu calendário oficial de vacinas ${ }^{19}$ as doses contra o HPV para meninas 9 anos a 13 anos, em 2015, e mais algumas outras para ambos os adolescentes (meninas e meninos), como a Febre amarela, a Tríplice viral, a Hepatite B Dupla (SEGATTTO, 2014), e a mais recente inclusão, a Meningite $\mathrm{C}^{20}$.

Um dos fatores que mais marcou a trajetória da vacina HPV no DF foi sua entrada na escola. As secretarias de saúde, como mencionado, foram orientadas a programar a vacinação no ambiente escolar, o que suscitou diferentes concepções sobre o assunto. Entretanto, falarei mais especificamente sobre isso no capítulo dois e três. Gostaria mesmo de ressaltar que preconizadas junto às diretrizes de vacinação no DF, também havia as regras que deveriam ser seguidas dentro das escolas. Umas delas é que as instituições de ensino deveriam informar, com antecedência, aos pais ou responsáveis, a data da vacinação, bem como informar as alunas sobre a vacina e seu motivo (QUEVEDO; INÁCIO, 2014).

${ }^{19} \mathrm{O}$ DF possui um calendário oficial de vacinas de rotina. O estabelecimento de um calendário de vacinação deve contemplar dados epidemiológicos, imunológicos, tecnológicos, logísticos e socioeconômicos. Da mesma forma, a proposta deve ser de fácil compreensão e manuseio, além de socialmente aceita. A inclusão de uma vacina como rotina em um calendário deve levar em conta a possibilidade de prevenir enfermidades que se constituam em um problema de saúde pública. Embora não seja indicada a utilização de um calendário único e universal, existem recomendações institucionais em nível nacional e internacional que devem ser referências para elaboração de esquemas de imunização, desde que regularmente atualizadas. (FEIJÓ, 2006, p. 14)

${ }^{20}$ O Ministério da Saúde vai modificar o esquema da vacina meningite C e vai passar a ofertá-la para adolescentes. Em 2017, ele começa com 12 a 13 anos. Em 2020, estarão contemplados todos meninos e meninas entre 9 e 13 anos. Foram registrados ano passado 15 mil casos de meningite no Brasil. Desse total, 30\% de meningite C. As duas medidas fazem parte da estratégia do governo de ampliar a vacinação entre adolescentes brasileiros. (AGÊENCIA ESTADO, 2016) 
Salienta-se que as escolas atuaram como um dos principais locais de articulação ativa da vacinação, onde a vacinação das adolescentes ocorreu sem a necessidade de autorização ou acompanhamento dos pais ou responsáveis legais. Porém, caso os pais ou responsáveis legais não autorizassem, deveriam encaminhar um termo de recusa. Além disso, houve a recomendação da realização de um registro nominal das adolescentes vacinadas, para que possam ser "encontradas" nas situações de não comparecimento nas doses aprazadas. (2014, p. 7)

Para a menina que fosse se vacinar, bastava que os pais ou responsáveis enviassem o cartão de vacinas desta. Já nos centros de saúde, a adolescente que quisessem se vacinar deveria apresentar o cartão ou a carteira de identidade, sem a necessidade de autorização dos pais ou mães, como esclarece a reportagem da Agência Brasil a baixo:

O Estatuto da Criança e do Adolescente (ECA) prevê que o adolescente pode ser imunizado, quando procurar o serviço por iniciativa própria e desde que receba esclarecimento sobre a vacina. "Os adolescentes são responsáveis por seu atos quando a procura se faz de forma espontânea, desde que devidamente orientados pelos profissionais de saúde sobre o procedimento, sua importância e riscos”, diz a nota do Ministério da Saúde. (BRASIL, 2010)

Frente ao destaque que o DF alcançou a nível nacional quanto a organização da vacinação do HPV e objetivando na nota técnica a meta de vacinar 100\% das meninas, o GDF não alcançou este objetivo, pois a adesão da população caiu entre as doses subsequentes, como explica o secretário de saúde do adjunto do DF à época, Elias Fernando Miziara:

Na primeira dose, tivemos uma adesão perto de 94\%. Miziara explicou que a diferença para o resultado final da vacinação $(79,4 \%)$ decorre de vários fatores. "As meninas, muitas vezes, esquecem a vacina, ou não tomam mesmo, ou ficam com medo, ou acham que já estão vacinadas". (...) “Tinha a questão dos pais, dos religiosos”. Ele lembrou que na segunda dose, a cobertura foi de 89\%, em 2013. (GANDRA, 2014)

$\mathrm{Na}$ fala do secretário descortinam-se alguns temas que começam por reposicionar a vacina do HPV diante da recomendação biomédica pela vacina. Outros fatores - como medo, falta de informação, religião - queriam demostrar que a escolha pela evitação da vacina passa também pelos valores pessoais, morais ou religiosos. Há um mundo social que envolve a 
vacina e não pode ser desconsiderado. E isto parece ser reconhecido pelas instituições, afinal está na fala do secretário de saúde. Embora o sucesso do primeiro ano de vacinação e a adesão no calendário oficial, a procura pela vacina do HPV tem diminuído, não só do DF, mas em todo o Brasil (JABUR, 2015).

Colosso de pés de barro

O resultado, em termos concretos, dessa campanha frenética de agitação contra a vacinação fez-se logo sentir. Enquanto, no mês de julho, cerca de 23.021 pessoas haviam procurado os postos de saúde pública para serem vacinadas, no mês seguinte, esse número havia caído para 6.036. E isso em meio a um surto fortíssimo de varíola que devassava a Capital, Rio. (GAZETA DE NOTÍCIAS, 23 de setembro de 1904. apud SEVCENKO, 2011)

Até 31 de março, apenas 212.299 meninas com idades entre 9 e 13 anos receberam a primeira dose da vacina contra o papiloma vírus humano (HPV) no Estado do Rio de Janeiro. O número representa $28 \%$ do público-alvo, de acordo com o levantamento divulgado nesta quarta-feira pela Secretaria de Estado da Saúde. A adesão à vacinação contra a doença, que começou no início do mês, vem caindo ao longo do tempo. Ao todo, as meninas devem tomar três doses para ter a proteção garantida - e o número de garotas que recebe a vacina costuma diminuir ao longo das doses. $\mathrm{Na}$ campanha de imunização do ano passado, enquanto a primeira dose atingiu 100\% do público-alvo, a segunda chegou a não mais que $60 \%$ das meninas. O número de pouco mais de quinto das meninas imunizadas na primeira dose representa, portanto, um sinal de alerta para as autoridades de saúde. (CORREIOWEB, 21 de maio de 2015)

Há semelhanças quanto à participação da população entre estes dois fragmentos jornalísticos, respectivamente, de 1904 e 2015. O primeiro fragmento relata a baixa participação da população na vacinação contra a varíola, antes da Revolta da Vacina. O segundo recorte, também ressalta a baixa participação da população, só que em relação às doses subsequentes da vacina do HPV.

Estes contextos, embora distantes no tempo, guardada as ressalvas de cada época, revelam similaridades quanto ao posicionamento do governo (de se preocupar com a baixa adesão vacinal), quanto ao da população (de não ter participado como esperado). Não 
desconsidero que as duas vacinas tiveram sucesso em seus feitos, sendo que a revolta da vacina acabou por vacinar muitas pessoas, mesmo com tamanha contrariedade. E o DF em 2013, vacinou 62 mil garotas (BÓRIS, 2014). Entretanto, para este último caso, o vacinômetro apontou que em 2015 foram vacinadas apenas 7.628 meninas $^{21}$ no DF. O governo, de acordo com a reportagem de Morais (2015), tinha como meta vacinar 21 mil meninas: "Começa nesta terça-feira (3) a vacinação contra HPV de meninas que completam 9 anos em 2015 no Distrito Federal. A meta é imunizar 80\% do público-alvo, que é de 21 mil garotas” (MORAIS, 2015). Segundo Quevedo e Inácio (2014), os dois fragmentos jornalísticos podem inferir:

Isto infere que recusa a vacinas não é novidade e o procedimento pode gerar medo na população quando uma tecnologia acabada chega para uso cotidiano sem preparo prévio. A história parece se repetir agora, depois de pouco mais de um século, ao se observar a maneira e a forma com que ocorreu a campanha de vacinação contra o $\mathrm{HPV}$, considerando as deficitárias e duvidosas informações disseminadas pelo Ministério da Saúde (MS) à população que também reagiu com desconfiança diante da tecnologia. No entanto, diferentemente do início do século XX, a vacinação do HPV vai além de um receio da população. A vacina apresenta considerável controvérsia científica na comunidade médica, oriunda da suspeita de que não seja 100\% segura à saúde por apresentar sérios riscos de efeitos colaterais. (2014, p. 6)

No século XX, houve um acelerado desenvolvimento da medicina tecnológica, produzindo inúmeras vacinas, medicamentos, micro-organismos. Isso favoreceu a queda da mortalidade, rapidez nos diagnósticos e tratamentos, logo, maior expectativa de vida (NOVAES et al, 2012). Entretanto, face a tantos benefícios, a confiança cega na ciência não foi alcançada. Os dois fragmentos são importantes por serem bons exemplos "das dificuldades de se ter um julgamento absoluto sobre os fundamentos racionais da vacinação e do interrelacionamento do social e do científico" (MOULIN, 2003, p. 501). Esses episódios trazem consigo a reconfiguração da relação entre os indivíduos e os grupos detentores das técnicas médicas - corpo profissional da biomedicina. Nesse sentido, um dos casos mais marcantes

\footnotetext{
${ }^{21}$ Consulta feita em 18 de fevereiro de 2017. Este número refere-se à primeira dose da vacina HPV quadrivalente apenas em meninas de 9 anos, em todos os serviços públicos no DF, no ano de 2015 (excluídas as doses realizadas nos serviços privados/particulares e as faixa de 10 e 11 anos). (BRASIL, 2017)
} 
desse "conflito" é a troca de lugar da vacina do centro dessas práticas de saúde atuais, "de saber incontestável à prática duvidosa”, pois

os progressivos avanços no conhecimento e tecnologias na área da vacinologia, os êxitos da políticas públicas de imunização e a queda da mortalidade por doenças imunopreveníveis convivem com a heterogeneidade da cobertura vacinal e nível socioeconômico, o ressurgimento de doenças controladas como o sarampo, e as resistências e reações sociais contrárias revelam tensões (...) entre a saúde pública e coletiva. (DONNANGELO, 1979, p. 16 apud BARBIERI, 2014, p. 150)

Entender a vacinação como apenas uma solução global para prevenção das doenças talvez não seja mais o caminho, afinal,

basta uma única vacina ser vista como ineficaz ou perigosa ou mesmo apenas suspeita para que o edifício inteiro vacile. Colosso com pés de barro, a instituição da vacina é abalada cada vez que uma vacina é questionada ou revela suas falhas. (MOULIN, 2003, p. 509)

Como Hochman (2012) ratifica, "[vacinas] também não são produtos desencarnados de interesses. Dizem respeito a poder, desigualdade, inclusão, controle, direitos civis, políticos e sociais" (p.03). Listo abaixo alguns acontecimentos pelo mundo que tiveram como mote a vacina, mas que representaram interesses diversos apresentados por Hochman e abalaram a instituição vacinal:

- 1991: Um surto de sarampo tem início na Filadélfia a partir de duas igrejas fundamentalistas antivacinação, nas quais nenhum de seus membros eram imunizados. Entre eles, foram 486 casos e seis mortes. A epidemia se espalhou pela comunidade e infectou 938 pessoas;

- 2005: Contabilizados na Nigéria 20 mil casos de sarampo e 600 mortes após líderes religiosos fundamentalistas desaconselharem a vacinação contra a doença;

- 2011: É registrado um surto de sarampo na Vila Madalena, em São Paulo, a partir de uma escola em que uma das crianças não era vacinada por opção dos pais;

- 2015: Autoridades do Paquistão decidem punir com prisão cidadãos que, por motivos religiosos ou pessoais, não se imunizassem contra a poliomielite. $\mathrm{O}$ governo anunciou que só liberaria os detidos se eles se comprometessem a tomar a vacina. 
- 2016: O Distrito Federal registrou 1.181 casos de caxumba em moradores da região, este ano. Os dados são do Boletim Epidemiológico n ${ }^{\circ} 6$ da Secretaria de Saúde. (...) Não existe um tratamento específico para a doença, o que não é desculpa para não se imunizar. O combate é feito pela vacinação ainda na infância. (MARQUES, 2016)

Estes casos ajudam a pensar a vacina especialmente para além do foco da saúde. Estratégias não-vacinais podem ser políticas, podem contestar posições, podem mandar recados. Não são artefatos livres de interesses, como ressaltou Hochman. A ideia é que ao invés de considerar a resistência como um fenômeno puramente negativo, prevaleça a ideia de analisar as representações e as práticas das pessoas, das comunidades, admitindo que essas possam ser fundamentadas e que reflitam experiências. Mas não só isso. Tratam-se também de experiências que politicamente desafiam as ações estatais, baseadas numa racionalidade epidemiológica ou em "evidências", as quais tendem a encompassar as diversas experiências, práticas e racionalidades voltadas à saúde.

Para a vacina em estudo, o HPV, cabe conhecer nos casos que serão apresentados adiante, o que de fato essa negativa representou e qualificou. Adianto que não foram muitos os casos de evitação da vacina encontrados em campo, porém foram fundamentais para um entendimento mais encorpado acerca das questões que a envolve. Pela grandeza que seria analisar isso em um contexto amplo, como o Brasil, ou mesmo abrangendo

o DF, intentarei no capítulo seguinte pensar todo este processo vacinal do HPV dentro de um cenário micro, como uma escola, que recebeu a vacinação e acionou todos seus atores e instrumentos pedagógicos e políticos para ratificar tal fenômeno. 


\title{
Capítulo 2. A ENTRADA NA ESCOLA
}

\author{
Hoje acontece a vacinação, \\ No Colégio do meu Distrito, \\ É óbvio, para a prevenção \\ De um órgão menos visto
}

\begin{abstract}
A importante vacina HPV.
E o Colégio tem parceria

Para então, ajudar prever

$E$ as mulheres terem alegria.
\end{abstract}




\section{Escola também é Estado}

Ao realizar esta pesquisa etnográfica dentro de uma escola, considero importante situar brevemente o papel desta instituição na vida social, falar da relação entre educação e saúde, descrever o cenário escolar conhecido e contextualizá-lo a partir de quem e como o preenchiam. Dedico cada um destes recortes um dos tópicos a seguir.

Uma abordagem muito comum sobre a escola é a clássica teoria de Foucault sobre a disciplina e os corpos, o que reforça a ideia de vigilância e controle exercidos pela escola. Segundo Foucault (1987) para que a tecnologia de poder disciplinar funcione bem, foram criadas "instituições disciplinares", nas quais os indivíduos são confinados: a fábrica, o exército, a prisão, o hospital, a escola. Nessas instituições, as pessoas são individualizadas. Por meio da disciplina o indivíduo pode ser conhecido, controlado e explorado, tirando-se dele tudo o que possa oferecer, tornando-o assim em "corpo dócil" (FOUCAULT, 1987, p. 133). A escola, nesse caso, é um claro ambiente de molde e a Pedagogia, a ciência do ensino, "é o conjunto de teorias que preparam as ações dos profissionais para agir nesse processo educacional" (DINIZ, 2014, p. 46).

Bourdieu (1983), por sua vez, via na educação e nos modos como esta era conduzida, um dos pilares que sustentavam a sociedade como um campo de dominação, por meio da reprodução dissimulada das desigualdades sociais, e via a escola como legítima para a interiorização dessa cultura dominante.

O sistema escolar cumpre uma função de legitimação cada vez mais necessária à perpetuação da "ordem social" uma vez que a evolução das relações de força entre as classes tende a excluir de modo mais completo a imposição de uma hierarquia fundada na afirmação bruta e brutal das relações de força. (BOURDIEU, 1983, p.311)

Para Souza (2012), estudiosa do autor, Bourdieu sustentava que a cultura escolar, era dominada pela cultura burguesa daquele momento e reproduzia as "ilusões necessárias à manutenção do sistema: as crenças compartilhadas em um campo. Sendo que, a família, a escola, o meio não só reproduzem as desigualdades sociais, mas legitimam inconscientemente esta reprodução” (BOURDIEU, 1983 apud SOUZA, 2012, p. 37). A desigualdade não residia, 
de acordo com Bourdieu, no acesso ao campo [a escola], mas no âmago do próprio sistema. A escola, da qual era esperada a transformação da sociedade e a possibilidade de ascensão social, ratificava e reproduzia as diferenças sociais.

Frente às disciplinas $\mathrm{e} / \mathrm{ou}$ às desigualdades, a moralidade escolar pretendida ultrapassava o corpo individual. Nessa lógica, para além de “educar", a escola é o ambiente onde as medidas de higiene, alimentação, convívio são remodeladas ou intensificadas, afinal, um corpo, além de eficiente, precisa ser educado, civilizado, limpo. Essa lógica "formatou as propostas educacionais, a formação de professores, a inspeção de alunos e de organização de espaços e equipamentos, objetivando a formação" (CASEMIRO, 2014, p. 835) de “adequados" cidadãos, onde se procura fortalecer a ação e o protagonismo do Estado.

Mas este não foi um processo simples e nem rápido. A escola e as práticas de saúde necessitavam de uma ponte que pudessem interligá-las - o discurso higiênico. "A preocupação com a higiene das pessoas e das cidades e sua transformação em um conjunto de normas e leis, com objetivo de controlar doenças e de melhorar a vida em sociedade, foi decorrência de um longo percurso histórico" (HOCHMAN, 1998 apud LAROCCA; MARQUES, 2010, p. 753). Iniciado por volta do final da idade média se desdobrando até os tempos atuais.

Nobert Elias, em O Processo Civilizador (1939), esmiúça como essa relação entre higiene e práticas sociais se deu à época da Idade Média. Ao adotar uma perspectiva mais processual da história, o foco de sua obra é analisar os manuais de etiqueta desde antes da idade média e perceber como os costumes foram se estabelecendo, se construindo e se disseminando. Elias queria entender melhor como a formação do Estado Nacional caminhou junto à transformação de um status de sensibilidade, nesse caso, de limpeza, de ordem, de higiene. Para ele, existe um sentido social arraigado nesse processo.

Seu estudo começa por um dos mais interessantes instrumentos dessa ordem, que é o livro Da Civilidade em Crianças, de Erasmo de Rotterdam, de 1530. Este livro é um tratado e fala de "um assunto muito simples: o comportamento de pessoas em sociedade - e acima de tudo, do decoro corporal externo” (ELIAS, 1939, p. 66). Caracterizado como um dos primeiros manuais de "etiqueta", Erasmo de Rotterdam não apenas copilou o que via em outros livros, diria Elias, mas tentou representar um código social especial, uma coletânea de observações feita da vida, feita sobre seu momento histórico. Os manuais eram representações de regras sutis, que intentavam mudança corporal, vigilância. E este, embora sobre crianças, abrangia 
também uma sociedade que passava agora a coação exercida de uma pessoa sobre outra e a exigências de bons comportamentos. Os manuais, posteriormente, viraram um instrumento argumentativo da saúde, da higiene. Chegou-se, assim, a uma racionalização da saúde, com regras escritas. E, posteriormente, a razão sanitária se constituiu.

De fato, o que Elias estuda é a construção do indivíduo moderno, por meio de uma "parede invisível das emoções" (1939, p. 79), o qual aponta Costa e Endo (2014), que repelia, separava, e reordenava as pessoas por meio do corpo e suas emoções, como nojo, asco, vergonha. Os espaços de "intimidade coletiva" vão sendo pouco a pouco restritos quando em presença do outro. "Tudo o que tem a ver com as pulsões e com as funções corporais vai lentamente sendo deslocado para o âmbito privado, escondido do alcance dos olhos, do nariz e da boca das outras pessoas" (COSTA; ENDO, 2014, p. 20). Como efeito, criam-se formas de auto regulação que causaram as mudanças nos processos histórico-sociais com os processos psíquicos.

Algo importante a frisar é que o processo civilizador é apenas uma face que explica a mudança de comportamento naquele momento. Por exemplo, a introdução do uso do garfo à mesa, por volta do século XVII, não teve muito a ver com o medo de doenças ou problemas com a higiene. Para Elias,

“mais do que uma questão de saúde, foi o sentimento de repugnância que levou as pessoas a abandonarem o hábito de comer com as mãos pelo comportamento "civilizado" de utilizar o garfo. Esse utensílio, assim, não passa de uma resolução prática do sentimento de nojo e das associações produzidas quando se pega com as mãos alimentos engordurados e molhos" (COSTA; ENDO, 2014, p. 24).

A ideia de higiene apenas veio aparecer depois, quando se percebeu que a vida em sociedade, acima de regras de comportamento, precisava do controle social. De acordo ainda com os autores, algo deveria regular a ordem nas cidades, as práticas de saúde, as pessoas. Foi um momento onde as doenças começaram a se revelar cadeias de moralidades. Mas foi preciso aguardar o século XIX e o movimento higienista para que se produzisse uma nova mudança de mentalidade. Apenas mais tarde,

O 'cuidar de si' foi preconizado por meio de conselhos médicos divulgados novamente por meio de manuais de boa conduta, que se encontravam embebidos do ideal 
iluminista de uso da razão humana para promoção do progresso social. (LAROCCA; MARQUES, 2003, p.2)

Ainda conforme Larocca e Marques (2003), o processo de construção do sistema público de ensino foi concomitante ao movimento higienista e, ambos, complementaram a consolidação do Estado. "Educação e saúde juntas tornaram-se uma peça fundamental, considerada como mecanismo não apenas de formação do cidadão, mas também como elemento gerador e multiplicador do progresso" (GONÇALVES NETO; MAGALHÃES, 2009)

Assim, a higiene ganha status de ciência e também de prática médica por volta do início do século XIX, segundo Hochman (1998). Como disciplina acadêmica, se destacou na Alemanha em meados de 1860, servindo de alicerce para o desenvolvimento e regeneração social (AROUCA, 1975, apud HOCHMAN, 1998). Como ciência, se institucionalizou, produziu práticas e discursos, os quais encontraram eco e visibilidade na atuação dos indivíduos, e porque não falar, do Estado. O conceito de limpeza reforçou o que antes já estava sendo construído, que era a moldura das sensações corporais - Elias (1939) apontou isso. "Gradualmente tornaram-se "rituais de saúde", com o intuito de alavancar a cidadania, numa cruzada pela saúde, educação e civilidade a um só tempo" (ROCHA, 2003 apud LAROCCA; MARQUES, 2003, p. 14).

A aliança entre Estado, pedagogia e medicina colocou todos os aspectos da vida das crianças em evidência no interior da escola e suas mínimas manifestações foram cuidadosamente escrutinadas: além das aulas, as brincadeiras de pátio, a merenda, as vacinas, os exercícios físicos, a higiene corporal, tudo foi tomado como campo de intervenção e produção de verdades sobre a infância, formando-se um sistema disciplinar no qual os exames corporais compuseram medidas centrais no processo de educação escolarizada. No contexto disciplinar, a higiene e a saúde destinavam-se à construção de uma população saudável; o civismo, à formação de uma população amante dos valores nacionais; ao passo em que o letramento destinava-se à produção de uma população de trabalhadores esclarecidos. Assim se configuraram os valores absolutos de todos os projetos nacionais de educação, os quais tomaram a infância como objeto de suas práticas de conformação visando à produção de uma população 
adulta viável, previamente preparada para as formas de governamento centradas na gestão do trabalho, da família e da saúde. (CÉSAR, 2004, p.123)

No Brasil, a escola é uma instituição que surgiu no âmbito do Estado, parte de uma sociedade política e civil. A ela, como aponta César (2004), coube preparar as crianças para serem adultos direcionados para trabalhar, cuidar da família e ter saúde, sempre sob supervisão da tríade - Estado, Pedagogia, e agora, a Medicina (Higiene). Segundo Sacristán (2005), a escola é uma "invenção cultural singular, uma forma de utilizar o espaço e o tempo" (p. 139), tendo sua implantação generalizada e bastante parecida em vários aspectos, apenas com diferenças regionais e locais. Quando se fala em educação formal como instituição intencionase dizer:

Entendendo a educação formal (Torres, 2001) como uma instituição social, como um epicentro de socialização do sujeito pedagógico (idem, 2001) e do ator coletivo (Mellucci, 1996), é de fato necessário notar que o espaço escolar é mais um elemento do conjunto organizativo e ordenador da sociedade (Torres, 2001; Giroux, 1999). E quando enxergamos mais além e percebermos a educação formal, ou seja, aquela que é atribuída pelo Estado ou supervisionada por ele (idem; 2001; 1999), num cenário complexo e anti-sistêmico (Freire, 1997), no processo de construção da alteridade social, compreendemos que a construção do sujeito pedagógico fará parte da própria gerência e manutenção da ordem social e do seu saber articulado. (MONTEIRO, 2004, p. 225)

Visando a manutenção da ordem social, ao longo do tempo o Estado ampliou o seu poder de modo a não atuar apenas coercivamente, mas também consensualmente. A melhor forma encontrada foi por meio da inculcação do discurso/disciplina perpassados por esta instituição. Segundo Milstein (2003), ao usar o referencial europeu, a escola ficou no lugar da Igreja para disputar o monopólio da educação - e vai se consolidando entre os séculos XVI e XIX, em lugar de superioridade com a família e para controle social, pois "se trata de uma instituição criada na Europa pela Igreja, para os filhos dos pobres, os quais começaram a se aglomerar nas cidades"22 (p. 22, tradução nossa), servindo assim a interesses diversos. O Estado ao entender a saúde como fator importante para a ordem civilizatória viu a possibilidade de

\footnotetext{
22 "Se trata de una instituicion creada em Europa por la Igreja destinada hacia los hijos de los pobres que comienzan a aglomerarse em las ciudades".
} 
articulação e importância tática com a escola, pois a higiene era um dos requisitos dos que os novos tempos impunham.

Segundo a mesma autora, há tempos se formou uma tríplice aliança do sanitarismo médicos, sanitaristas e professores. Higiene, civismo e letramento, apontados por César (2004) eram atividades destinadas às escolas, pois estas não são apenas instituições didáticas, mas possuem um status civilizador e moral. Conforme Souza e Jacobina (2009), a higiene em nome da segurança social autorizou a escola a vigiar e gerenciar a vida das crianças e por contiguidade das famílias, por meio da ideia fixa de prevenção ${ }^{23}$, a qual inundou os discursos de saúde a partir da intensificação do fenômeno da medicalização ${ }^{24}$. Cuidar ou se preocupar com a saúde confere a instituição escolar uma boa imagem social, pois traz prestígio e legitimidade ao salvar/resguardar o cidadão.

No Brasil essa relação se estreitou apenas no início do século XX, momento em que houve a necessidade de inculcação de hábitos civilizados numa sociedade recém-saída de um sistema imperial e escravocrata, que recebia grande quantidade de imigrantes, estava com o comércio e as cidades aquecidos (GOLDEMBERG, 1993). O país estava aquém de outras sociedades que há muito já havia vivido suas reformas estruturais, sejam urbanas ou educacionais, como países vizinhos, tal qual a Argentina. Esta, conforme Sarlo (1996) iniciou suas reformas estruturais por volta dos anos setenta do século XIX, o que o Brasil apenas conseguiu realizar já no início do Século XX. Este retardo é apontado por Goldemberg (1993) como reflexo do sistema escravocrata e das elites tradicionais:

A pesada herança da escravidão tem consequências de longo prazo para a evolução do sistema educacional porque cria problemas específicos para a extensão do acesso à escola. De um lado, pelas mudanças de tradições, valores e hábitos exigidas de uma população para a qual a escola não faz parte da perspectiva normal de vida nem integra sua tradição cultural. De outro lado, pela resistência das elites tradicionais em estenderem a cidadania a escravos e ex-escravos e, portanto, pela dificuldade em aceitarem e promoverem o ideal da escolarização universal como fundamento das políticas públicas. (GOLDEMBERG, 1993, p. 34)

\footnotetext{
${ }^{23} \mathrm{O}$ destaque explica-se por esta palavra ganhar notoriedade em todo o texto. Deve-se atentar sempre que ela aparecer, pois não deixa de ser uma retórica biomédica quanto uma representação que perpassa a representação da vacina HPV feita pelos interlocutores da pesquisa.

${ }^{24}$ A medicalização é um fenômeno através do qual a vida cotidiana é apropriada pela medicina e interfere na construção de conceitos, costumes e comportamentos sociais. (BRITO, 2012)
} 
Segundo Jacobina (2009) o objetivo das atividades educativas não era promover a autonomia ou possibilitar o acesso aos grupos excluídos, pois os interesses econômicos e da classe dominante cafeeira estavam por trás das políticas de saúde. Seu objetivo era fazer com que as pessoas aceitassem as intervenções do Estado e se sujeitassem às imperiosas leis da Higiene $^{25}$. Ainda assim muitas pessoas se rebelaram como ocorreu com a famosa Revolta da Vacina, abordada no capítulo um.

“O diretor do Departamento Nacional da Saúde Pública em 1920 sugeriu que os programas das escolas primárias deveriam incluir os novos hábitos em seus currículos, para que não fosse necessário modificá-los posteriormente” (SOUZA, 2012, p. XX). Nesse momento, a infância foi tida como a fase ideal para a criação de hábitos que possibilitariam a higienização dos indivíduos, aliás, das crianças. As reformas educacionais no Brasil em parceria com a saúde de modo oficial e institucional se deram com o Decreto n. 19.402 de 14 de novembro de 1930, momento que foi criado o Ministério dos Negócios da Educação e Saúde Pública.

O decreto organizou o Conselho Nacional de Educação e a Constituição de 1934 deulhe a incumbência de criar o Plano Nacional de Educação. Em 1932 alguns intelectuais brasileiros como Lourenço Filho, Fernando de Azevedo e Anísio Teixeira, dentre outros (no total de 26), assinaram o "Manifesto dos Pioneiros da Educação Nova". (ARANHA, 2009, p. 30)

Desse modo, o Estado voltava sua atenção a esses dois temas - saúde e educação uma vez que pretendia contribuir para a melhoria do processo de estabilização social iniciado há pouco. Estabilização essa perseguida pelo governo diante do momento turbulento que o país passava, conforme aponta Cassiano (2002), no qual a classe trabalhadora realizava diversas manifestações reivindicando melhores condições de trabalho e justiça. Segundo Aranha (2009), não demorou para que os intelectuais percebessem a insuficiência da pedagogia tradicional diante da exigência do mundo moderno, logo, as instituições escolares deveriam ser atualizadas de acordo com a nova realidade social. Até o momento, "as ações educativas restringiram-se a

\footnotetext{
25 Uso letra maiúscula para marcar que esta já era uma ciência à época.
} 
programas e serviços destinados à margem do jogo político, continuando a priorizar o combate a doenças infectocontagiosas" (SOUZA; JACOBINA, 2009, p. 622) e precisavam ser modernizadas.

Importante ressaltar que a partir de 1942, com a criação do Serviço Especial de Saúde Pública (SESP), a educação sanitária encabeçou a formação de professoras como agentes de saúde:

A primeira grande transformação de mentalidade nas atividades da educação sanitária (...) começou com o SESP, que reconheceu a educação sanitária como atividade básica de seus planos de trabalho, atribuindo aos diversos profissionais, técnicos e auxiliares de saúde, a responsabilidade das tarefas educativas, junto a grupos de gestantes, mães, adolescentes e à comunidade em geral. Foi o SESP que começou a preparar as professoras da rede pública de ensino como agentes educacionais de saúde. (SOUZA; JACOBINA, 2009, p. 624)

$\mathrm{Na}$ década de 50, o então Ministério da Educação e Saúde (MES) acabou por se desdobrar em dois: o Ministério da Saúde e o Ministério da Educação e Cultura, com autonomia institucional para elaboração e implantação de políticas em suas áreas.

Entre 1964 e 1980 houve diversas reorganizações administrativas do Ministério da Saúde e uma delas deve ser lembrada "a mudança de nomenclatura de educação sanitária para educação em saúde diz respeito a mudanças nos paradigmas vigentes na prática educativa da época" (SOUZA; JACOBINA, 2009, p. 630). Esta alteração visava estimular o desenvolvimento do cidadão quanto à compreensão de sua saúde:

O objetivo da educação em saúde, por sua vez, não é o de informar para a saúde, mas de transformar saberes existentes. A prática educativa, nesta perspectiva, visa ao desenvolvimento da autonomia e da responsabilidade dos indivíduos no cuidado com a saúde, porém não mais pela imposição de um saber técnico-científico detido pelo profissional de saúde, mas sim pelo desenvolvimento da compreensão da situação de saúde. (BRANDÃO, 2011, p. 125)

Esta era uma vertente que agora se aplicaria às escolas, a educação em saúde implicava novas metodologias para ser promovida e a escola deveria acompanhar essas mudanças. Assim,

no transcorrer do século XX, a saúde escolar no Brasil experimenta avanços em sintonia com a evolução técnico-científica, deslocando o discurso tradicional - de lógica 
biomédica -, para a concepção da estratégia Iniciativa Regional Escolas Promotoras de Saúde (IREPS), um discurso de múltiplos olhares que surge no final da década de oitenta," como parte das mudanças conceituais e metodológicas que incorporam o conceito de educação em saúde na saúde pública, estendendo-o ao entorno escolar. (LIMA, 1985, p. 78)

De 1980 até o início dos anos 2000, passando pela redemocratização do Brasil e pela Constituição Federal de 1988 (formação do Sistema Único de Saúde - SUS), muitas foram as iniciativas e abordagens que pretendiam focalizar o espaço escolar e os estudantes a partir e/ou dentro de uma perspectiva que articulassem as unidades de saúde às unidades escolares.

Em 2006, "surge a Política Nacional de Promoção da Saúde (PNPS), editada pelo Ministério da Saúde, que é um importante marco político/ideológico para a organização do Sistema Único de Saúde” (MALTA, 2009, p. 80). A criação do PNPS retomava e deveria contribuir para o aprofundamento das promessas da reforma sanitária brasileira, porém nos moldes da universalização, da busca da equidade, da integralidade do cuidado e do respeito à cidadania - baseando-se assim nos princípios do SUS.

Nos dias de hoje no Brasil, originada desta última política, surgiu o Programa Saúde na Escola (PSE) instituído pelo Decreto 6.286, de 05 de dezembro de 2007, em parceria interministerial da Educação e Saúde a nível Federal, uma das ações que até agora mais se destacou ao aproximar as áreas de educação e saúde dentro da história brasileira. Ressalto que o percurso histórico realizado até aqui não tem a intenção de cobrir todo os detalhes desta parceria, mas servir de base para se conhecer o que antecedeu e apoiou a formulação da política do PSE.

Tal política é guiada pela intersetorialidade das pastas de saúde e educação para divulgação das ações em saúde nas escolas, na qual "tratar a saúde e educação integrais como parte de uma formação ampla para a cidadania e o usufruto pleno dos direitos humanos" (BRASIL, 2015) é sua maior diretriz. Estas ações estão preconizadas nos Cadernos de Saúde Pública e também nos Cadernos do Gestor do PSE - belos manuais modernos à la Elias - os quais descrevem as regras do programa, como devem ser implantadas. Descrevo em detalhes a política, pois é ela que direciona a vacinação enquanto recomendação e vigilância por parte dos pactuantes da política, ou seja, saúde e educação, especialmente quanto à atualização do calendário vacinal. 
A imunização contra doenças transmissíveis tem eficácia clara e amplamente documentada. (...) Possibilitar o cumprimento do calendário de vacinas dos órgãos oficiais é obrigação do sistema de saúde e de todos os profissionais envolvidos, devendo ser seguido com atenção. (BLANK, 2003 apud BRASIL, 2009, p. 25)

O que as escolas são chamadas a fazer, a partir desse projeto, é construir uma educação transversal, que significa envolver diferentes disciplinas e atividades escolares nas vidas dos alunos, especialmente, em relação ao cuidado e manejo da saúde, o que inclui as vacinas. Segundo Ferreira (2014), no Distrito Federal, o programa PSE teve sua implementação nos anos de 2009 e 2010, objetivando desenvolver suas ações nas escolas da rede pública.

Esse programa tem como objetivo contribuir para a formação integral dos estudantes da rede pública de educação básica por meio de ações de prevenção, promoção e atenção à saúde. Seus eixos organizativos giram em torno da promoção da atenção integral; integração e articulação permanente entre as políticas e ações de educação e de saúde, com a participação da comunidade escolar, envolvendo as equipes de saúde da família e da educação básica. (BRASIL, 2015)

No DF, além das ações preconizadas pelo PSE, existem decretos distritais que reforçam a atuação desta parceria no que se refere à saúde e aos direitos das mulheres. O Decreto n. 35.991 de 11 de Novembro de 2014 é um exemplo e instituiu o I Plano Distrital de Políticas para as Mulheres. Em seu capítulo dois, no tema "Educação para a Igualdade" e "Nos temas de saúde", encontra-se a ênfase na promoção das questões de diversidade em gênero, raça, etnia, sexualidade e saúde nos sistemas de ensino, socioeducativo e sócio assistencial do Distrito Federal. Também há metas e ações referentes à vacinação do HPV,

Disseminar as questões relativas à sexualidade e DST’s em articulação com o calendário da vacinação contra o HPV nos sistemas de ensino, socioeducativo e sócio assistencial.

Consolidar a imunização contra o HPV conforme protocolo do Ministério da Saúde. (SEDF e SECRIA, 2014).

Com bases nesses planos, a recomendação foi que as regionais de saúde de cada cidade do DF, articulassem junto às regionais de educação a operacionalização das ações nas escolas. Em termos práticos para a pesquisa, isto quer dizer que cada regional de saúde definiria sua estratégia de vacinação, de acordo com a logística e realidades locais das cidades. 
Baseadas na diretriz da OMS, onde "Toda criança tem o direito e deve ter a oportunidade de ser educada em uma escola promotora de saúde" (OMS, 1954, p.10) e também no PSE e decreto, as escolas devem buscar e preparar seu ambiente para as ações em saúde. Isto envolve estratégias que permitam divulgar, internalizar e permitir prevenções diversas, como quanto à acuidade visual, pressão sistêmica arterial, audição, avaliação nutricional, DST's, acompanhamento psicológico, dentre outras. Mas não só, devem ser espaços para divulgação de campanhas governamentais, espaços para que as políticas do Estado intervenham, lugares de confronto de diferentes saberes e condutas, afinal,

a escola é um importante espaço para o desenvolvimento de um programa de educação para a saúde entre crianças e adolescentes. Distingue-se das demais instituições por ser aquela que oferece a possibilidade de educar por meio da construção de conhecimentos resultantes do confronto dos diferentes saberes: aqueles contidos nos conhecimentos científicos veiculados pelas diferentes disciplinas; aqueles trazidos pelos alunos e seus familiares e que expressam crenças e valores culturais próprios; os divulgados pelos meios de comunicação, muitas vezes fragmentados e desconexos, mas que devem ser levados em conta por exercerem forte influência sociocultural; e aqueles trazidos pelos professores, constituídos ao longo de sua experiência resultante de vivências pessoais e profissionais, envolvendo crenças e se expressando em atitudes e comportamentos. (BRASIL, 2009, p. 14)

Dentro desta concepção, muitas campanhas públicas são levadas à escola, dentre elas e no âmbito do DF, cito algumas: redução do consumo de água; combate à cárie dentária, combate à Dengue e Zica (mais recentes); imunizações vacinais, como a do Zé Gotinha ou Dia $\mathrm{D}^{26} \mathrm{e}$, finalmente, à da vacina do HPV.

Não pretendo dizer que antes do PSE não havia programas atenção à saúde nas escolas, havia sim, tanto que nas entrevistas, as pessoas adultas (maioria acima de 40 anos) se lembravam de uma "pistolinha ${ }^{27}$ que a Saúde usava para vacinar as pessoas dentro das escolas" (DIÁRIO, 15 de abril de 2016). Lembravam-se também de aprender a escovar os dentes na

\footnotetext{
${ }^{26}$ Este é o Dia de Campanha Nacional de Vacinação. Geralmente, ocorre aos sábados, pode ser realizado no âmbito da escola ou nos centros de saúde, pretende atualizar o calendário vacinal de crianças e adolescentes que estejam com vacinas atrasadas. Lembrando que para o público feminino de 9 anos à 13 anos, estão sendo disponibilizadas as vacinas do HPV.

27 As pistolas injetoras de vacina na época (anos 70 e 80, aproximadamente) tinham a forma aproximada de um revólver. Ao apertar-se o gatilho, o aparelho injetava, sob pressão, o líquido na pele de quem era vacinado. Protegiam contra a varíola. (NASCIMENTO, 2015).
} 
escola, de seguir orientação nutricional. O que quero mostrar é que estas políticas ampliaram e fortificaram, ao longo do último século, os laços entre a saúde e a educação. Afinal, parafraseando o título desta seção, escola também é saúde.

No âmbito do DF, foram os dois programas, o PSE e o PNI que abriram as portas das escolas para a entrada da vacina HPV, porém muito mais do que estes, o próprio desenho da política de saúde preconizado pelo governo do DF, reforçou esta entrada ao incluir expressamente a vacinação nas escolas.

Para a escola, aceitar a vacina é dar continuidade a via da disciplinarização, é se reafirmar enquanto Estado, é contribuir para o projeto do bom cidadão - instruído e higienizado, é responder às suas responsabilidades enquanto campo de normalização e adequação social.

Considerando que as características e a composição dos lugares contribuem para demarcar um fenômeno, no sentido que existem especificidades nos espaços sociais que redesenham os fatos sociais, apresentar a escola que estou tratando é fundamental. Para além de pensar a educação em seu caráter "burocrático-institucional", deve-se pensar que a educação é também forjada por uma cultura escolar, ou culturas escolares, inspiradas por Monteiro (2004), afinal ela influencia no cotidiano e em todo o desenrolar do processo vacinal.

A produção de conhecimento se faz basicamente através da experiência cotidiana dos indivíduos, desde suas crenças e composições simbólico-culturais, à sua disponibilidade econômica, e seu contexto social. $\mathrm{Na}$ escola, lugar onde se produz conhecimento e onde se constituem imaginários sociais, nos vemos diante de diversas culturas escolares, contextos e situações de apreensão de "representações sociais". A escola, pois, não será um mero espaço de reprodução das relações sociais. É também um espaço onde a criticidade do que se aprende pode se desenvolver, justamente por haver uma cultura onde diversos sistemas simbólicos interagem, como nos coloca Bourdieu (2005). Este autor entende que é o espaço da escola, além do da família, o campo simbólico do saber é capaz de gerar, numa espécie de movimento dialético, a “inculcação do arbitrário" e o "arbitrário da inculcação” (MONTEIRO, 2004, p. 224).

Não se pode deixar de pensar na possibilidade que esta cultura escolar é capaz de construir e nos revelar acerca das realidades sociais. Por isso, considero valioso apresentar o cenário escolhido para a pesquisa e como ocorreu minha entrada nele. Sigo adiante. 


\section{Adentrando a escola}

Hoje a vacinação aqui no posto é pela procura espontânea. Não vamos mais às escolas. Deu muito problema, nem vou comentar os nomes das escolas. As meninas é que vêm aqui acompanhadas pelos pais para vacinar. E só pode vacinar acompanhadas e com cartão. Quando eu vou à escola, eu sei que não vacino só pessoas do Guará, tem muita gente de outras satélites. O que eu sei é que o Gama ainda tá fazendo a vacinação nas escolas, eles precisam desafogar as salas de vacinação. Mas é melhor você checar. (DIÁRIO, 26 de maio de 2015)

Assim cheguei à cidade do Gama. Cheguei por meio da indicação de Lorena, a técnica de enfermagem que conheci no CS do Guará - já apresentada na introdução. Foi ela quem me alertou para o fato da vacina ainda estar sendo distribuída nas escolas do Gama. Lorena era tida como "especialista" em vacinação, segundo suas colegas de trabalho. Falavam isso porque ela "estava por dentro de toda a vacinação do HPV, pois vacinou o Guará todo, produziu dados, era a principal técnica de enfermagem da sala de vacina do posto” (DIÁRIO, 26 de maio de 2015). Tal afirmativa me deixou mais confiante ainda para seguir as pistas que ela me dava. Afinal, pretendia desde o início da pesquisa encontrar uma escola que ainda receberia a vacinação para poder acompanhar o processo ao vivo.

Seguindo as pistas de Lorena, em uma tarde de sábado, ao conversar com minha mãe, que é professora de uma escola pública no Gama, lembrei-me de perguntar se na escola dela já havia acontecido a vacinação. Ela me contou que por lá estava um "bafafá danado" por causa da vacina, pois o centro de saúde tinha marcado um dia específico para ir à escola, o que demandava organização e aviso nas salas por parte da Direção. Fiquei contente com a notícia e pedi que me avisasse quando seria esta visita. Quatro dias depois ela me comunicou que eles estariam na escola.

Numa tarde de junho de 2015, conheci a escola pela primeira vez. Tinha acabado de sair de uma aula na UnB e fui direto para o Gama, o que contabilizava uns quarenta minutos de carro, aproximadamente. Não posso negar que precisei da ajuda da minha mãe para uma apresentação introdutória da pesquisa, ela precisou falar com a coordenadora Fernanda sobre a minha presença naquela tarde. Com a concordância desta, pude acompanhar a vacinação, que aconteceu no período da tarde. Entretanto, não falarei deste dia por hora. O que desejo antes é 
apresentar e contextualizar a escola em questão, mostrar com mais detalhes o campo. Como expliquei, há um motivo para isso.

Comparativamente a Pereira (2016), que trabalhou com experiências juvenis dentro de escolas públicas em São Paulo, a qual pesquisa muito me identifiquei, apresento a escola do Gama como detentora de uma estrutura global, quanto de estruturas locais. Global enquanto "um dispositivo educacional ou disciplinar, com o objetivo de formação de sujeitos" (PEREIRA, 2016, p. 13), e local, ao buscar descrever as realidades específicas dos lugares onde se situam este estabelecimento de ensino, junto a seus atores.

Para melhor compreensão das diversas manifestações, práticas e situações vividas em campo, penso ser necessário uma apresentação prévia do lugar da escola. Este termo lugar retoma os estudos de Marc Augé (2005 apud Sá, 2014) que busca sua definição segundo o ponto de vista antropológico, como a localização de uma comunidade social no tempo e no espaço, quanto ao caráter identitário, relacional e histórico. Lugar é um espaço no qual se imprime um grau de afetividade que resulta das vivências, pois este autor

parte de uma concepção do espaço cujas bases são encontradas no pensamento de Georges Simmel, para quem o espaço físico e o espaço social estão juntos, um não existe sem o outro: "A ação recíproca faz do espaço, até então vazio e nada, qualquer coisa para nós, preenche-o enquanto ele a torna possível” (SIMMEL, 1992, p. 601). (SÁ, 2014, p. 32)

Talvez por espelhar essa ligação entre o mundo físico e o mundo social, as descrições dos cenários e lugares para a Antropologia sejam válidas por "mostrar" como é esse lugar e transportar o leitor, afinal de conta, "Ler nos transporta. Como os etnógrafos melhoram essa jornada para que os leitores aprendam fatos sobre um lugar e também algo da sensação de estar lá? ${ }^{28 "}$ (NARAYAN, 2012, p. 30, tradução nossa). Acredito que detalhando de diferente formas o lugar. Bem, sigo para a escola.

O colégio em questão está situado no Gama, uma das regiões administrativas mais antigas do Distrito Federal. O DF é comporto por Brasília, Capital Federal, e mais 31 Regiões Administrativas - RA. Dentre elas, está o Gama, formado em 1960, a partir de um povoado criado originalmente para acolher as famílias de um aglomerado urbano situado na barragem

\footnotetext{
${ }^{28}$ Reading transports us. How do ethnographers enhance this journey so that readers glean facts about a place and also something of the feel of being there?
} 
do Paranoá, além dos moradores transferidos da Vila Planalto e da Vila Amauri (que foi submersa pelas águas do Lago Paranoá) e dos habitantes do Setor de Indústrias de Taguatinga (COSTA; PELUSO, 2016). Ele está a $30 \mathrm{~km}$ de Brasília, localizado ao sul do DF - fazendo divisa com o Estado de Goiás - e entre duas importantes rodovias federais (BR-060 e BR-040).

A cidade conta com aproximadamente 141.911 mil habitantes, segundo a Pesquisa Distrital por Amostra de Domicilios (PDAD, 2015). O Gama é conhecido como a capital do Entorno, pois é polo econômico e geográfico para cidades goianas vizinhas - Novo Gama, Valparaíso, Cidade Ocidental, Luziânia e Santo Antônio do Descoberto. Mas não só isso, seus serviços de saúde, escolares e de comércio também são atrativos para esta população próxima.

O Gama é formado por uma área urbana e outra rural, sendo que a área urbana dividese nos setores Norte, Sul, Leste, Oeste e de Indústria. Parte da população é de renda média baixa, cuja "a média mensal por família na região é de $\mathrm{R} \$ 4,4$ mil e a individual, de $\mathrm{R} \$ 1,3$ mil." (CODEPLAN, 2011). Entretanto, há um crescente número de famílias de baixa renda e carentes dos serviços oferecidos pelo governo. Há ainda dados de escolaridade e de cor:

Do total de habitantes, 51,36\% se declaram pardos e 38,09\%, brancos. O estudo diz que mais da metade da população se considera católica. Sobre escolaridade, 73,83\% dos moradores não estudam. Os que frequentam escola pública somam 17,96\%, com 0,66\% em período integral. Em escola particular, apenas 8,21\%. Quanto ao nível de escolaridade, $32,96 \%$ dos habitantes têm o ensino fundamental incompleto. Somente 25\% dos 141.911 habitantes concluíram o ensino médio. (CODEPLAN, 2011)

Predominantemente pardos, católicos e com menos de 25\% dos habitantes com ensino médio concluído, estes dados ajudam a configurar a cidade do Gama. Porém, é importante ressaltar que:

Mapas ou levantamentos estatísticos, ainda que apontem alguma diversidade, também apresentam perspectivas um tanto quanto homogêneas, pois mesmo dentro das áreas classificadas por determinado nível econômico também se pode encontrar uma grande diversidade de modos de vida e mesmo de níveis de privação social. Contudo, considero relevante a apresentação de dados como esses para um panorama que contribua para um olhar mais distanciado, capaz de compreender padrões mais gerais dos lugares pesquisados. (PEREIRA, 2016, p. 37) 
Ao encontrar ou não com os dados acima, boa parte das pessoas que conversei caracterizou o Gama como periferia, "lugar distante do Plano", "uma cidade boa, mas invadida pelo entorno". O que inclui os adolescentes e jovens da escola. Isto é muito importante porque demostrou como eles viam e percebiam sua cidade ou o local em que estudavam, pois segundo Pereira (2016), da mesma forma que itens como telefones celulares, bermudas de marcas, tênis, maquiagem começam, cada vez mais, a fazer parte do cotidiano juvenil, e reposicionar as relações, as noções de seu espaço, lugar, pode ser utilizada pelos jovens como elemento de auto reconhecimento.

Neste contexto estava localizada a escola do Gama. Ela era rodeada de casas, havia uma igreja católica, duas igrejas evangélicas, dois pontos de ônibus próximos, e um comércio, que além das padarias e mercadinhos, encontravam-se também bares e botequins. Seus muros eram altos, com cerca de arame farpado em algumas partes. Eram pintados com propagadas comerciais ou, em outras partes, estava grafitados. Ao longe, conseguia-se ver as grades da quadra de futebol. Havia dois portões. Um para os pedestres, que era a entrada da frente/principal, onde havia uma guarita. E outro, do lado de trás, quero dizer, oposto a esse, que servia para a entrada dos carros dos professores. Passemos aos intramuros. 
Conto agora com um mapa artesanal, a intenção dele é ajudar na compreensão dos espaços que irei apresentar como se estivesse andando pela escola.

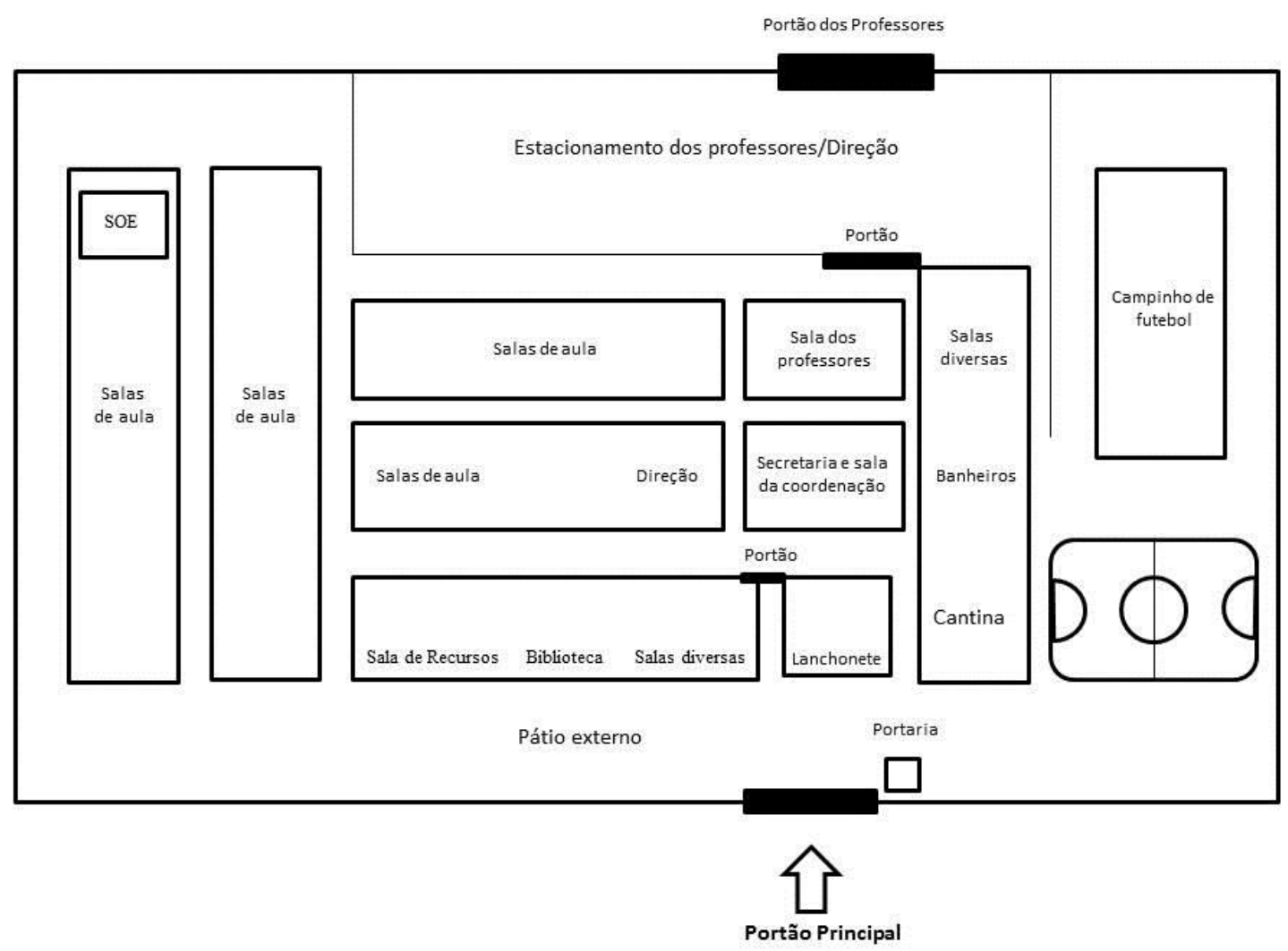

Figura 1 - Esquema de disposição dos espaços da escola

Ao cruzar o portão principal da escola, por onde entrava o público em geral, havia um grande pátio, com muitas árvores altas, vistosas, mastros para bandeiras, alguns bancos de concreto, uma lanchonete particular e um extenso bloco de salas à esquerda. Neste bloco havia duas salas de recurso multifuncionais29 - uma para atendimento de jovens com deficiência visual - essa sala era chamada de "Sala de Recursos da Regional", por atender todos os alunos do Gama que possuíam cegueira ou baixa visão. A outra era a sala de recursos própria da escola, que atendia jovens com deficiências, físicas ou cognitivas, estudantes de lá. Durante a

\footnotetext{
${ }^{29}$ São salas para a oferta do Atendimento Educacional Especializado - AEE, prestado de forma complementar ou suplementar aos estudantes com deficiência, transtornos globais do desenvolvimento, altas habilidades/superdotação matriculados em classes comuns do ensino regular, assegurando-lhes condições de acesso, participação e aprendizagem. (MEC, 2016)
} 
pesquisa, notei que as salas de recurso eram muito valorizadas pelas alunas/os e pelos professores, pois eram muito bem equipadas e contavam com bons profissionais atendendo nelas, o que trazia destaque e orgulho para a escola.

Ao lado desta, tinha uma biblioteca, que possuía dois ambientes, um só para leitura, com mesas individuais ou de grupo; e outro espaço, com estantes com livros, revistas, enciclopédias, para a pesquisa. A biblioteca foi apontada por algumas alunas/os como pequena e obsoleta, visto que possuía apenas um computador e não era muito frequentada. Por ser silenciosa, às vezes eu a utilizei para entrevistas ou grupos focais, era um lugar tranquilo para uma boa conversa ou uso do gravador.

À direita da biblioteca, havia duas salas sem uso definitivo. Uma destas era do laboratório de informática, que foi desativado. Disseram-me que a escola não recebeu todos os computadores necessários e nem aparelhos de ar condicionado para manter a sala refrigerada, então, a Direção recolheu os computadores e colocou alguns na sala da coordenação, que atendiam aos professores. Nos dias que estive em campo, esta sala estava cedida para uma faculdade particular que desenvolviam atividades e projetos na escola, detalharei mais à frente. Bem ao lado esta sala, havia um portão com grades que separa o pátio externo das salas de aula e da Direção.

Ao passar pelo portão para os blocos de salas de aulas, encontrava as salas da Direção. Quando uso o termo "Direção", com letra maiúscula, quero me referir à gestão administrativa e pedagógica da escola, nas figuras, principalmente, do diretor, da vice-diretora e da coordenadora - eram eles os maiores poderes hierárquicos da escola. Ali se localizavam a sala da diretoria, a sala da coordenação, e a secretaria escolar - esta última cuidava das xerox, dos diários de classe, das notas, da papelada em geral que uma escola precisava gerir. Dentre este conjunto administrativo, a secretaria era o espaço que mais mantinha vínculo com o mundo externo, ainda que de maneira limitada, por meio de uma janelinha de aço que, em horários fixos, se abria para atender o público em geral.

Próximo dali havia o que costumei chamar de "pátio interno", lugar da cantina, de fazer as refeições, de sentar para conversar, era o lugar de maior sociabilidade dos jovens. Tinha banheiros também e uma área de bebedouros e mesas de concreto, pintadas de azul. A cantina da escola preparava os lanches indicados por cardápio próprio da Secretaria de Educação em parceria com a Secretaria de Saúde, visando oferecer uma alimentação 
balanceada aos alunos e alunas. Fazia também cafezinho para os professores e preparava almoços, estes apenas para os estudantes do período integral ${ }^{30}$. Havia também uma lanchonete privada que vendia salgados, refrigerantes e doces além de contar com uma grande procura no intervalo por professores e alunas/os.

Passando por esses blocos apresentados, lá atrás, ficavam a sala dos professores, a sala do pessoal do administrativo e a sala do pessoal da limpeza. Nessas duas últimas eu entrei muito pouco, frequentei a sala do Administrativo apenas para pegar o documento que autorizava minha pesquisa ali, por parte da Direção; e na da limpeza, para pegar um café ou usar o banheiro, quando os outros estavam trancados ou sendo limpos. Diferentemente destas, a sala dos professores eu frequentei bastante. Era o meu segundo lugar em campo. Era uma sala com armários de aço individuais, mesas coletivas, sofás, geladeira, televisão. Lá convivi, conversei, conheci muitos professores, lanchava, participava das vendas - em algumas tardes apareciam por lá mulheres com malas gigantes para vender todo tipo de roupa, sapato, artesanato, comida, como queijos e doces. Era uma sala animada, sempre se ouviam gargalhadas, mas também se ouviam lamentos, pelos maus salários ou por causa das danações dos estudantes. Quando eu precisava fugir do barulho ou escrever algo no caderno, eu ia para lá.

No último bloco da esquerda, encontrava-se o SOE - Sala de Orientação Educacional, a qual considerei meu primeiro e principal lugar em campo. O SOE era a sala das orientadoras ${ }^{31}$ educacionais, as quais participavam ativamente da vida interpessoal das alunas/os, possuíam trânsito livre na escola e nas salas de aula, marcavam encontro com os pais, dentre outras atividades. Acabaram por se tornar minhas colegas de trabalho, tanto por empatia quanto por terem sido elas as ajudantes da vacinação junto à Coordenação. As duas representantes dessa sala eram Inês e Silvia, introduzi-las-ei em momento específico.

O restante das salas era de aula. Eram divididas entre os professores da escola, pois ali, cada professor tinha a sua sala e eram nomeadas de acordo com a disciplina que ministravam por exemplo: sala de geografia, de matemática, de artes - devendo este professor ter a posse da

\footnotetext{
$30 \mathrm{O}$ ensino integral atende algumas crianças/adolescentes que chegam à escola às 10 horas da manhã e realizam atividades extras até o meio dia. Há vagas limitadas e é necessária a solicitação por parte dos pais.

$31 \mathrm{O}$ orientador educacional é um dos membros da equipe gestora, ao lado do diretor e do coordenador pedagógico. Ele é o principal responsável pelo desenvolvimento pessoal de cada aluno, dando suporte a sua formação como cidadão, à reflexão sobre valores morais e éticos e à resolução de conflitos. (PASCOAL, 2013)
} 
chave da porta, zelar pela conservação e limpeza desta, organizá-la, podiam mesmo até pintar a parede do fundo - vi duas salas com grafites temáticos encomendados, um da Frida ${ }^{32}$, na sala de artes e outro de uma célula, na sala de biologia. Naquela escola, eram os estudantes que se movimentavam na hora de trocar o horário, a cada batida do sinal. Rapidamente eles deveriam encontrar sua sala e arrumar um lugar para se sentar, pois a ordem era um bem valioso e exigido.

As salas de aula são a verdadeira "sala de estar" (mais que sala de visitas). Nelas se passa realmente o tempo, embora não seja o espaço mais confortável nem o que permite usos mais variados. Está repleto de mesas e cadeiras que preservam uma distância de pouco mais de um metro quadrado por pessoa; um minúsculo território onde nem sempre uma pessoa pode se movimentar sem ser advertida. (PEREIRA, 2016, p. 97)

Por falar em ordem, esta também existia entre os servidores da escola. Peço licença por um instante para pontuar desde já os lugares institucionais e hierárquicos que as pessoas ocupavam na escola. Para além de ser mais um conjunto de dados que contextualizam o ambiente, é importante falar disso porque estabelecimentos de ensino, conforme Pereira (2016), almejam bem definidas as posições de seus gestores/servidores, visto que há uma função socialmente definida para cada cargo e não cumpri-la ou passar por cima dela pode resultar em repreensão. Isso se aplica muito bem a mim, por ter meu papel social não marcado por hierarquias, mas especialmente confundido com diversos outros, o que era complicado, afinal fui interpelada algumas vezes a me reapresentar ou falar sobre meu trabalho dentro da escola.

Essa explicação sobre os cargos e as pessoas foi dada a mim por Fernanda, a coordenadora da escola, pois, de fato, eu mesma os misturei e confundi diversas vezes. Em uma entrevista pedi a ela que me esclarecesse como a estrutura hierárquica da escola era dividida. Utilizei os dados que ela me deu em um diagrama.

Natália: Então, vamos retomar o que você falou. Eu preciso de um esqueminha gráfico sobre a direção da escola porque eu fico louca, estou confundindo. Você me ajuda?

\footnotetext{
${ }^{32}$ Frida Kahlo foi uma pintora mexicana.
} 
Fernanda: Claro. Primeiro é o diretor. O diretor, ele é o chefe de tudo, ele é o chefe do administrativo, é o chefe da secretaria, é o chefe dos servidores de apoio e é o chefe dos professores, da equipe de coordenadores. Então na ausência dele, você coloca a vice-diretora. (...) Os coordenadores efetivos na regional são os três, considerando eu como coordenadora geral, o Patric, como coordenador de turno e o Tadeu, coordenador do integral. Temos ainda uma nova coordenação que eles [a Regional de Ensino] criaram, que é um apoio direto com o pedagógico, na figura da Karen, a supervisora pedagógica. (...) A gente não tem segurança e nem porteiro, mas o cargo existe. (...) Aí, para facilitar a vida da coordenação tem os professores conselheiros, que representam uma turma específica e tentam resolver os problemas daquela turma, são eles que fazem a ligação entre a Direção e as demandas da turma. (DIÁRIO, 25 de agosto de 2016)

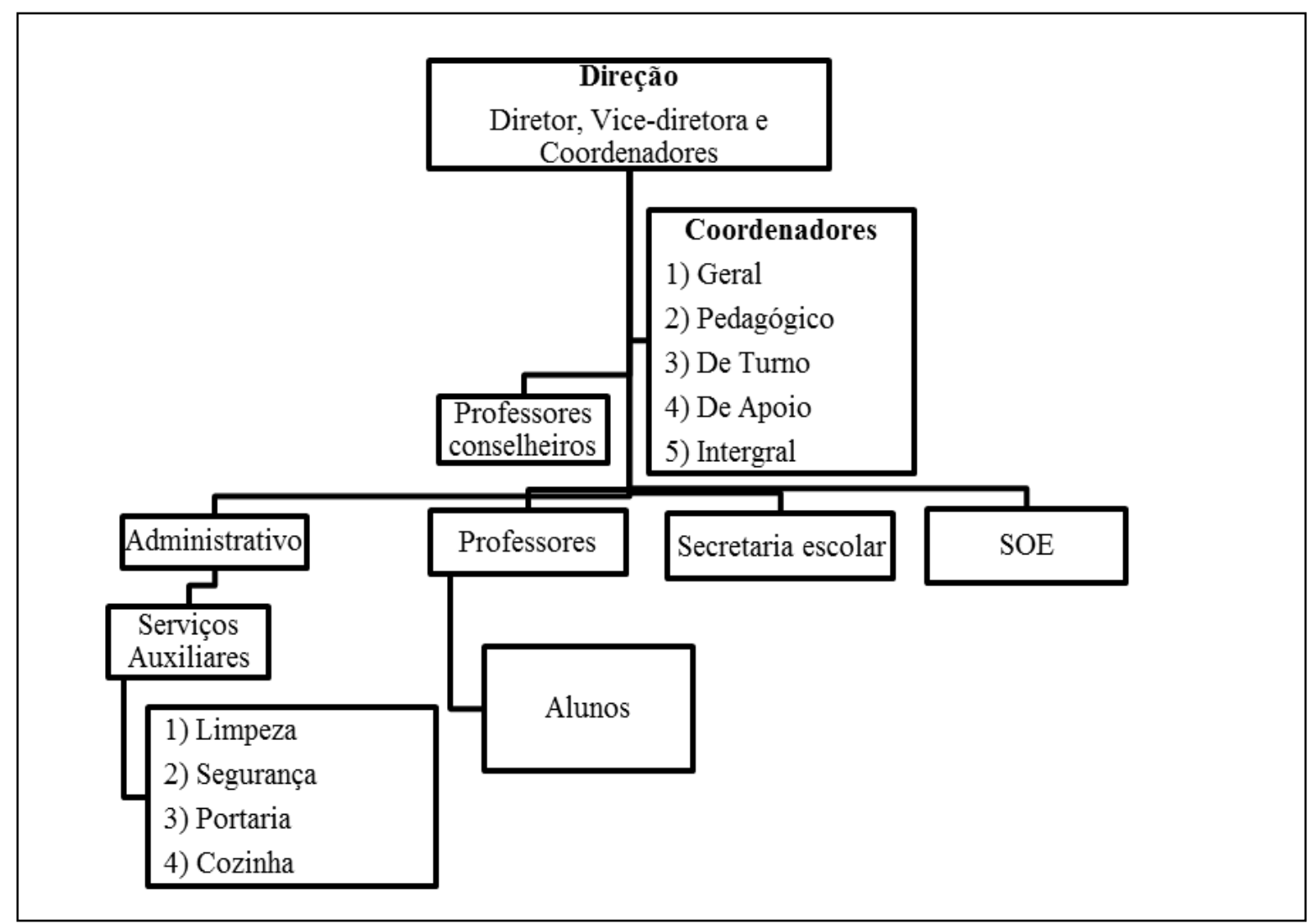

Figura 2 - Esquema hierárquico da escola 
Toda essa estrutura hierárquica administrava e planejava atividades para 37 turmas existentes na escola. Era oferecido o ensino fundamental, do $6^{\circ}$ ano ao $9^{\circ}$ ano ${ }^{33}$, no turno vespertino, e oferecido o ensino médio, do $1^{\circ}$ ano ao $3^{\circ}$ ano, no turno matutino. Na parte da tarde, turno pesquisado, a escola possui 17 turmas e atende, aproximadamente, 475 alunos, com 20 professores atuando. O sistema de avaliação é baseado em bom comportamento, nota para os cadernos (anotações do quadro e deveres), trabalhos feitos em sala/casa e provas interdisciplinares ${ }^{34}$.

\section{Cenário recôndito ou o âmbito das relações}

Falar de cenário recôndito é falar do lugar no âmbito das relações sociais. É falar sobre alguns aspectos da cultura escolar ali existente, é tentar vislumbrar uma parte da complexa rede que o espaço social da escola proporciona. Particularmente, enquanto antropóloga é repensar minha presença em campo e buscar conhecer, por meio das minhas próprias relações sociais, alguns traços escondidos por trás dela. Creio que as experiências vividas realimentam o nosso pensamento social e rearranjam as compreensões acerca do campo.

Começo por dizer que meus relacionamentos em campo se deram com adultos e também com crianças e adolescentes. Sei que essa divisão entre fases de vida é complexa, uma vez que,

vemos que existem diferentes concepções de crianças e de adolescentes que se fazem distintas a partir de diferentes pontos de vista teóricos e que acabam por contribuir para formar múltiplos conceitos desses grupos referidos. Assim, é necessário que pensemos melhor sobre quais são e como se construíram as diferentes concepções de

\footnotetext{
${ }^{33}$ Antigas $5^{\mathrm{a}}$ série à $8^{\mathrm{a}}$ série.

34 São provas temáticas (o último tema que acompanhei em meados de 2016, por exemplo, foi sobre os jogos olímpicos). São separadas em três dias, cada dia com uma área dentre Humanas, Exatas e Códigos. Como explica a coordenadora Fernanda: "expliquei a diferença de uma prova multidisciplinar pra uma interdisciplinar. Porque numa prova multidisciplinar cada professor monta suas questões e junta tudo num esqueminha que a gente chama de Frankenstein, pegamos pedaços de cada um dos professores e monta o Frankenstein. Agora é uma prova interdisciplinar que você pega um texto e em cima desse texto cada um vai criando uma questão é muito mais difícil" (DIÁRIO, 25 de agosto de 2016).
} 
infância e de adolescência na nossa sociedade ocidental ou na cultura em questão. (FROTA, 2007, p. 147)

Não gostaria de adentrar profundamente nesta questão, visto ser tal separação uma construção social que depende de inúmeros fatores, constituindo-se em categorias construídas historicamente e que sempre estão se reposicionando, afinal, "a adolescência é uma produção social" (VAZ; OLIVEIRA, 2003, p. 1) e depende do contexto social em voga. Porém, é importante fazer essa ressalva por ser a escola o espaço que propiciou a emergência e diferenciação das categorias de infância e juventude como dados importantes quanto à vacina HPV. Muitas meninas se consideram adolescentes ou "mocinhas", por estarem no grupo etário da vacina.

Solicitei algumas vezes que as interlocutoras da pesquisa, de diversas idades, pudessem me descrever o que seriam essas fases, em especial, o que era "ser criança" e "ser adolescente". As duas categorias foram diferenciadas assim na maioria das vezes: a) crianças - são "aquelas que o corpo ainda não se desenvolveu, que tem até uns onze, doze anos" (DIÁRIO, 30 de março de 2016); b) adolescente - "tem acima de 12 anos, tem espinha, as meninas tem peito, tem quadril”" (DIÁRIO, 30 de março de 2016). Quase sempre as descrições eram sobre aspectos físicos, sendo a idade um dado muito importante para caracterizar essas fases. Falavam da adolescência, de modo geral, como uma ponte entre a infância e a idade adulta.

A propósito, dentro das minhas categorias, entendo ter tratado com um público predominantemente adolescente. A maioria era meninas, entre os 12 a 14 anos, do sexto e sétimo anos, principalmente. Porém, também conheci e conversei com garotas de nove, dez, quinze, dezessete anos, que se autodenominaram "crianças" ou "jovens", e não "adolescente". Gostaria de pontuar que usarei a palavra adolescente ou jovem de modo amplo, quando me referir às meninas da pesquisa. Não intenciono dividi-las em fases.

Tendo frisado isso, permito-me falar sobre uma antropologia da adolescência. Meu ponto de vista ao trabalhar com esse grupo aproxima-se ao de Diniz (2014), no qual a ideia central é pensar uma antropologia da criança - no meu caso, da adolescência, colocando estas pessoas como seres sociais ativos, interativos, capazes de se representar e de pensar o mundo à sua maneira. Os adolescentes vivenciam suas experiências e podem 
desestabilizar nosso centro adulto, ao repensar categorias sociais a partir das experiências deles. (...) Realizar pesquisa com eles (...) exige de nós, adultas, um exercício permanente sobre lembrar a nossa provável posição social a partir da visão das crianças [e adolescentes] e buscar estabelecer diálogos fluidos. (DINIZ, 2014, p. 46)

Falei na introdução que esta era a primeira vez que lidava com adolescentes, pois apenas tive experiências com idosos em pesquisas anteriores. Portanto, foi um aprendizado estar no meio das meninas e dos meninos, especialmente ao lado delas. Estar em campo demandava energia extra, pois eu tinha que ter "disposição para estar com elas, no grupo delas, como uma amiga. Uma amiga adulta que brincava com elas, ouvia o que elas tinham a dizer, que conversava sobre os assuntos que lhes interessava” (DINIZ, 2014, p. 49).

Tornei-me não "tia", como é geralmente quando se trabalha com crianças do ensino infantil, mas era uma "amiga", a qual se abraçava toda vez que se via, dividia-se o lanche no intervalo, perguntava-se por ela quando sumia por um tempo, anda junto, ouvia-se atentamente, sorria-se. Recebi muito carinho em campo. Claro que, para um grupo curioso como são os adolescentes, eu era uma figura atrativa, por transitar entre vários lugares e portar utensílios incomuns. Conversava com os professores, ficava nas aulas, tomava café na cantina, anotava tudo em um caderno, tinha uma máquina fotográfica. Sei que não foi apenas a simpatia que me favoreceu nesta relação, mas a atenção que despertava, meus elementos de identificação. Por isso a peculiaridade desse grupo.

Nossos adolescentes amam, estudam, brigam, trabalham. Batalham com seus corpos, que se esticam e se transformam. Lidam com as dificuldades de crescer no quadro complicado da família moderna. Como se diz hoje, eles se procuram e eventualmente se acham. Mas, além disso, eles precisam lutar com a adolescência, que é uma criatura um pouco monstruosa, sustentada pela imaginação de todos, adolescentes e pais. (FROTA, 2007, p. 149)

Complementando tal peculiaridade, Frota (2007) traz ainda a fala do "pai da Psicologia da Adolescência" para a análise: "Stanley Hall considerava que a adolescência era a retirada dramática das crianças do paraíso da infância, constituindo-se, deste modo, num período de crises, tempestades e tormentas" (p. 157). Por isso, ainda nos detemos a falar da adolescência como uma fase difícil, rebelde e cheia de "crises". Essa mudança é vivida com grande sofrimento, mas temos de criar meios de substituí-la por novas aquisições reais, imaginárias e 
simbólicas. Para entender alguns traços de toda essa transformação, as expressões subjetivas dos jovens são muito importantes.

Ser do contra, ter manias com alimentos diferentes, vestir-se de forma estranha, cultuar ídolos, passar a gostar mais dos amigos que dos pais, conhecer novas religiões e até mesmo experimentar variadas formas de ser, todas essas vivências são comportamentos que fazem parte do processo de experimentação para encontrar a forma nova do ego. (FROTA, 2007, p. 154)

Segundo Maria Cláudia Lopes de Oliveira (2006), o que especifica a adolescência é a forma particular como o sujeito vai vivenciar, nas trocas sociais, elementos de identificação.

$\mathrm{Na}$ adolescência, ao menos nos contextos urbanos industrializados, tende a haver o predomínio da diferenciação sobre a imitação. Os adolescentes passam a criar sistemas semióticos (gírias, estilos de vestimenta e corte de cabelo, por exemplo) que são incorporados à chamada cultura juvenil típica de cada geração. Enquanto na infância a identificação como imitação constitui o principal dispositivo de socialização, na adolescência passa a ganhar maior importância a diferenciação, tendência responsável pela enfática afirmação das marcas culturais típicas de cada geração. (OLIVEIRA, 2006, p. 443)

Sendo o Distrito Federal, como prega a autora, lugar "cuja população, além de jovem (30\% da população tem entre 11 e 24 anos) constituiu-se basicamente por meio da migração, esta cidade é marcada por ampla diversidade cultural” (2003), sendo os elementos de identificação essenciais para a formação das "tribos" 35 , pois tornou-se uma importante estratégia de formação cultural, bem como de inserção e agregação social, especialmente da população juvenil (ABRAMOVAY,1999).

O grupo parece representar uma fonte de socialização menos repressiva que a família (Marques, 1996), assumindo importante papel como fonte de referência social. Entre pares, com frequência, os adolescentes são menos exigidos a negociar perspectivas e encontram oportunidade de legitimar os próprios sentimentos e visões de mundo, norteados pela intensa identificação, compreensão, aceitação pelo grupo. (LOPES et al, 2003, p. 3)

\footnotetext{
35 As tribos são comunidades empáticas, organizadas em torno do compartilhamento de gostos e formas de lazer. Os vínculos comunitários perduram enquanto se mantém o interesse pela atividade (i.e., uma apresentação musical, uma festa ou manifestação política). (LOPES et al, 2003)
} 
Longe das referências dos modelos parentais, geralmente os adolescentes sentem necessidade de buscar seus ídolos e amigos - que às vezes podem ser os próprios professores (ibid., p. 4). Há os laços de amizades, as afinidades de gosto, os amores da adolescência. Não posso delinear como cada uma dessas manifestações ocorria em campo, pois não fiz um estudo aprofundado delas, não havia tempo e este não era o foco. O que fiz foi tentar observar estas características nos adolescentes pesquisados, e mais, buscar saber se elas interferiam no processo do cuidado da saúde, da vacinação.

Extraindo o que de bom havia nessas manifestações, a escola aproveitava o estilo dos jovens - gostos, estilo, animação - para realizar algumas atividades extraclasses, de entretenimento e aprendizagem, como a Feira das Profissões (Maio); a Feira das Regiões (Julho - em substituição da festa junina); Jogos interclasses (julho); Desfile de aniversário do Gama (outubro); Dia da Consciência Negra (Novembro), dentre outras. Essas atividades se mostram frutíferas por aproximar os discentes entre si, em relação à escola e também aos professores. Geralmente eram trabalhos em conjunto, como ensaios da quadrilha, decoração da escola e de murais, arrecadação de alimentos, dentre outras atividades. Percebi que os adolescentes se interessavam muito pelos trabalhos realizados, e buscavam cumprir sua parte com êxito, para que tudo saísse conforme o esperado.

\section{Composição 1 \\ Interações}

Fotos do dia da Feira das Regiões. No pátio externo, as amigas e mais um grande grupo de estudantes assistiam a apresentação de um colega que tocava sax e interpretava Luiz Gonzaga.

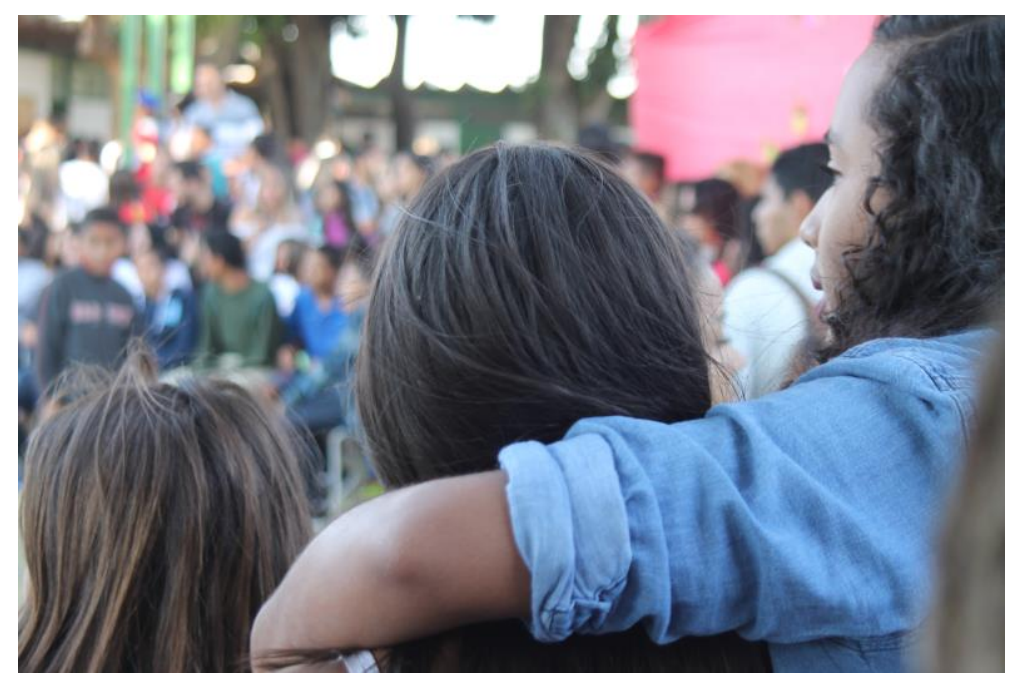

Julho, 2016. 
Foto tirada a partir da cantina. Alguns

alunos aguardavam o intervalo no pátio interno. Muitos não conversavam entre si, pois o celular tomava-lhes a atenção.

Maio, 2016.

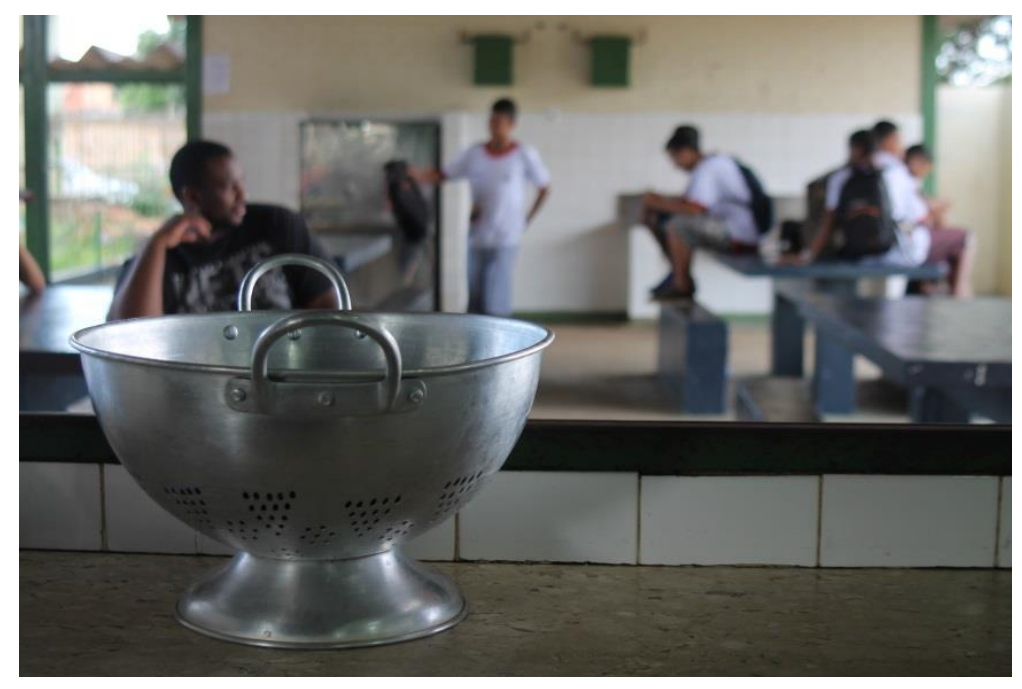

Em frente à sala de aula, as meninas aguardavam a chegada da professora, conversando.

Agosto, 2016.

Momento imediato após o lanche, que neste dia foi fruta com biscoito.

Maio, 2016.
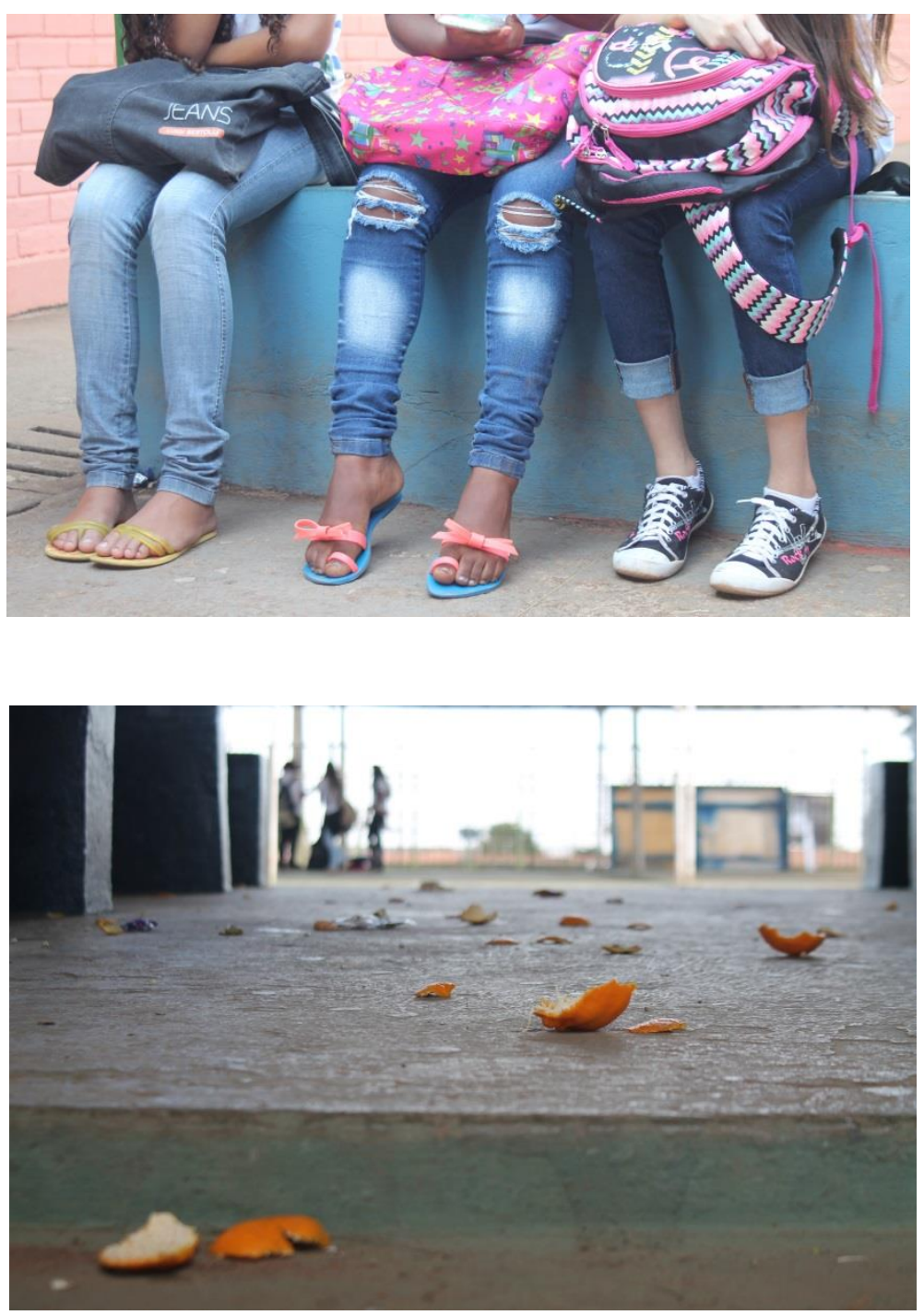
Percebe que as fotos acrescentam informações que ainda não tinham sido por mim reveladas? Quero com isso valorizar a presença delas enquanto informação etnográfica, visto que não são meras ilustrações do texto.

Diante da parceria, cooperação e interação, em contrapartida, não se pode deixar de considerar que entre os adolescentes também havia sentimentos de competição, raiva, rixa, enfrentamento, e tantos outros, que acabam por desencadear por um dos fatores que mais alteram a vida escolar, que é a violência. Baseada em Santos (2001), o reconhecimento da violência no espaço escolar, mostra-se um caminho interpretativo fecundo, pois contrapõe os velhos papéis institucionais - de socialização, perante o fato de esta ser locus de explosão de conflitos sociais. Trabalharei de modo mais específico sobre isto adiante.

Finalmente, uma antropologia da adolescência foi chamada a se juntar a uma antropologia da saúde para pensar o cenário complexo que é uma escola. A intenção desse tipo de abordagem é apresentar o ambiente escolar operacionalizado a partir do enredamento de duas dimensões, como sugere Diniz (2014). Primeira, a institucional, manejada por um conjunto de normas e regras, que pretendem regularizar e demarcar as ações dos seus sujeitos. E a segunda é a cotidiana, "em que as experiências, advindas das relações sociais entre os sujeitos envolvidos, ocorrem através dos saberes pessoais" (ibid., p. 50).

Assim, há a existência concomitante de muitos fatores, sejam materiais ou sociais, para uma escola funcionar e prestar com êxito seu propósito. Ambas dimensões possibilitam a percepção do processo de aprendizagem e de relações sociais de maneira ampla. Falar sobre os intramuros é mais do que uma fala sobre espaços ou hierarquias. É falar dos atores sociais que delinearam e usaram de representações para se posicionar, porém mais do que isso, para posicionar e significar a vacinação do HPV dentro da escola.

\section{Foto de Parede}

Com o intuito de ir além das palavras para representar algumas relações sociais que vi e vivi ali e também para complementar minha apresentação da escola, gostaria de inovar, testar 
algo. Afinal, as relações por vezes estão no âmbito do não dito sendo que apreendê-las é uma tarefa complexa. Então pensei em um desafio. Tentarei agora falar dos meus interlocutores por meio das pichações e grafites encontrados nas paredes da escola. Interessei-me por isso ao refletir: "Como negar que a pichação, sendo ou não aceita, se tornou um ato de intervir em algo já existente, provocar reações diversas, direcionar e alterar olhares para um fato ou lugar dentro da banalidade cotidiana, reinventando-a?" (VAZ; OLIVEIRA, 2012, p. 1).

Entretanto, não quero focalizar a violência escolar, visto esta dominar os desenhos e frases. É preciso falar dela, pois é real, mas não como objeto único e final. Quero mostrar que havia outras expressões, de amor, de paquera, de representação que contextualizavam a escola e as pessoas naquele lugar, pois entendo que inscrições nas paredes são auto definições - os jovens falando de si por eles mesmos, sem mediação, sem tradução.

$\mathrm{Na}$ escola encontrei pichação e grafite e de acordo com Vaz e Oliveira (2012), eles são diferentes, mas não excludentes um do outro:

A pichação (ou picho) é definida, na maioria das vezes, como uma condenável atitude de vandalismo, entendida como uma sujeira nas ruas da cidade, alimentando o preconceito de que pichadores são membros de gangues perigosas. O grafite, por sua vez, teria como preocupação a produção de imagens com estética agradável ao público, de ordem artística e feita somente com autorização. (2012, p. 2)

Escolho falar das duas sem contrapô-las. Frente a uma escola normalizadora de corpos e atitudes, falar delas é ver mais do que seu caráter delinquente ou artístico, mas é considerar sua intenção, as relações que se originam, o arranjo que propõem.

Pensando a prática educativa como algo que permite ao estudante construir maneiras de ver a si e ao mundo, a pichação não é utilizada para fixar discursos, levando indivíduos a subordinarem-se a ela, mas para desencadear interpretações que não dizem respeito apenas ao objeto, mas a um posicionamento sobre nossas relações com o mundo. Basta entrar em uma escola para percebermos o quanto marcas pessoais são deixadas pelos jovens, indicando sua passagem por ela. (VAZ; OLIVEIRA, 2012, p. 4)

Estas marcas, a bem da verdade, estão na contramão à “eficácia dos mecanismos de vigilância e de poder de Foucault” (PEREIRA, 2016), discutidos ainda a pouco. São táticas que 
segundo Certeau (2009) articulam os detalhes do dia a dia, configuram uma "antidisciplina" e expressam cultura da juventude contemporânea que convivi. $\mathrm{O}$ autor ainda aponta que

A importância de se atentar para certos procedimentos criativos do cotidiano que são postos em prática pelos atores e que geram dissonâncias na efetuação do poder pelas redes microscópicas de vigilância e controle de instituições como a escola. (CERTEAU, 2009 apud PEREIRA, 2016, p. 18)

Certa da possibilidade de se pensar o mundo social por outros caminhos, a maioria das pichações que eu encontrei foram feitas nos corredores da escola, nos muros internos, nas portas do banheiro, nas paredes das salas de aula. Em contrapartida, já os grafites os encontrei destacados, nos muros externos virados para rua, nas paredes da entrada da escola, ao lado da biblioteca, das salas de recursos, pátios, nos locais de sociabilidade juvenil mais livres. Estes últimos eram autorizados pela Direção ou encomendados por algum professor, ganhavam notoriedade frente às pichações que para a maioria dos professores não passavam de rabiscos que sujavam a escola e traziam a ideia de delinquência.

As marcas de juventude desaparecem dos espaços educativos voltados aos jovens e geralmente retornam a eles pela ação ativa e muitas vezes transgressora dos próprios jovens (...), são vistas como uma invasão ilegítima de elementos externos e estranhos ao trabalho educativo. Há, portanto, na escola, muitas lacunas e silêncios em relação aos jovens e a sua condição biopsicossocial. (CORTI, 2007 apud PEREIRA, 2016, p. 23)

Presenciei certa vez uma aluna com bucha e detergente esfregando a parede do lado de sua sala tentando apagar um palavrão que direcionou a uma colega. Não era comum os alunos apagarem seus escritos, até mesmo porque, na maioria das vezes, eram feitos resguardados dos olhares do outro, mas este dia enquanto a aluna escrevia, foi pega por uma professora, o que gerou o "castigo". Muito mais que ter que apagá-lo, a punição estava presente na "zoação"36 vinda dos colegas, que riam e faziam piadas.

\footnotetext{
36 Pereira (2016) utiliza o termo "zoeira”, no sentido de tirar sarro, brincar, pertubar, irritar. Usarei a categoria que encontrei em campo "zoação", que significa o mesmo.
} 


\section{Composição 2}

Fotos de parede I

Retrato de um dos corredores da escola. Estes eram os locais onde a maioria das pichações estava. Além de servirem como passagens, os corredores eram locais de vigilância, pois a movimentação de alunas e alunos que circulavam, entre as trocas de horário, para beber água, encontrar os amigos, os paqueras, ou fumar, eram controladas pelo coordenador de turno.

Maio, 2016.

Banheiros também eram pontos de encontros dos jovens. Tanto para as fofocas do dia a dia, quanto, segundo algumas alunas me contaram, para usar droga. As escritas nas portas do banheiro são diversificadas. Esta traz um alerta irônico.

Abril, 2016.
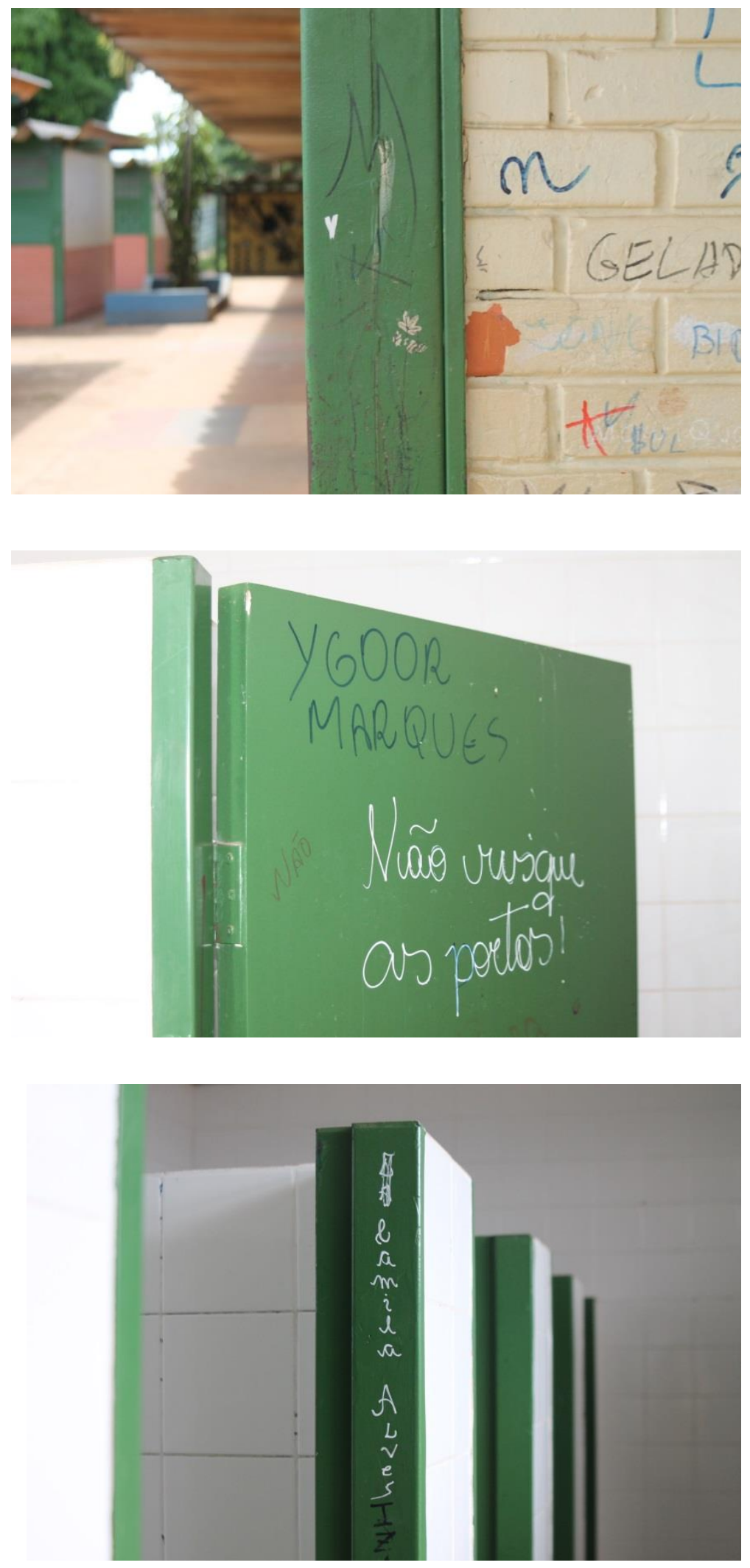


\section{Continuação.}

O amor também estava nas paredes, por meio do grafite ou das pichações. Uma das grandes descobertas da adolescência é o amor, a paquera, a sexualidade, que são um sinal importante da construção da subjetividade e das relações. Os adolescentes são sensíveis, disponíveis e ávidos para viver o namoro e o sexo. (RANÑA, 2002). Abril, 2016.

Frases religiosas também foram encontradas nos muros da escola. A religião pareceu ser, juntamente com outros tantos fatores, uma instância na vida dos sujeitos da pesquisa..

Abril, 2016.
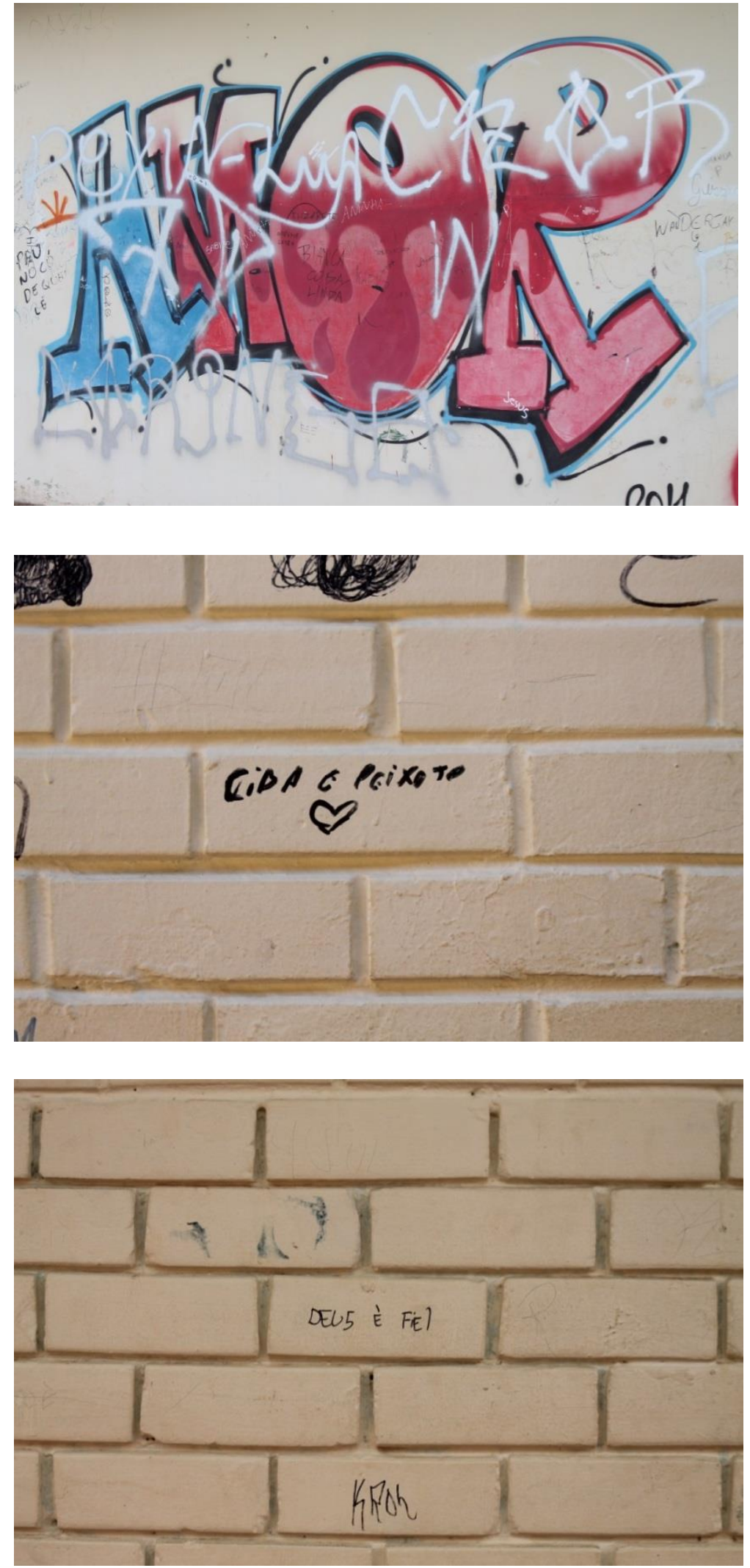


\section{Continuação.}

Conselhos como estes estavam nos grafites autorizados. Este ficava na parede ao fundo de um corredor.

Abril, 2016.

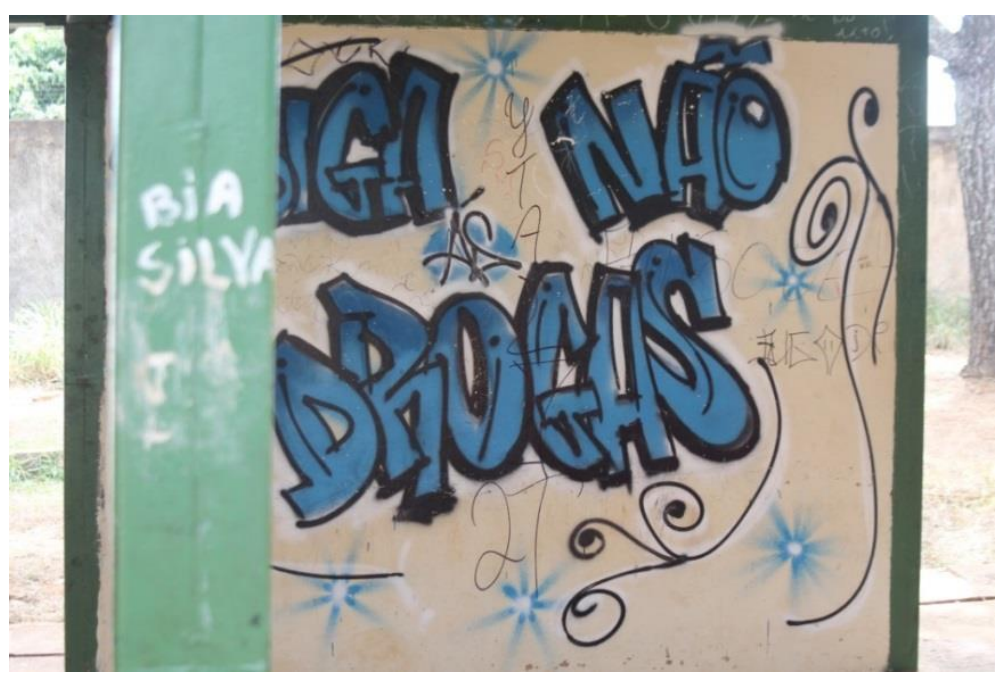

Pichações revelavam brincadeiras que ocorriam entre os alunos e alunas, contribuíam para explicitar a ambiguidade das relações de gozação, que carregavam consigo certo clima amistoso, mas que também marcavam o conflito aberto entre alguns os jovens. Eles estão a todo tempo reinventando o espaço escolar e a reprodução social da instituição. Estas diversas dimensões da vida humana, segundo Pereira (2016), são aspectos para serem valorizados pelo pesquisador por mostrarem-se importantes para a compreensão dos dados acessados na pesquisa. Por isso trazer todos estes componentes, a construção acerca da saúde não se faz sozinha no meio social, ela utilizasse de vários instrumentos para se desenvolver.

Porém, não apenas de bons sentimentos eu tenho fotos de parede. Sendo repudiada ou afirmada, a violência (de múltiplas formas) apareceu como uma questão relevante da pesquisa, e acabou por ser fotografada também. Segundo Santos (2001) a violência e a criminalidade vêm se apresentando dentro das escolas como mais um componente de sociabilidade. Vale ressaltar que aqui estou considerando o amplo conceito de violência e suas diversas formas de manifestação, não me arrisco a adentrá-las, visto serem estas um fenômeno a ser explicado a partir de determinações culturais, políticas, econômicas e psicossociais, intrínsecas a cada sociedade humana, sendo um conceito reconstruído no tempo:

Inicialmente, a violência na escola era tratada como uma simples questão de disciplina. Mais tarde, passou a ser analisada como manifestação de delinquência juvenil, 
expressão de comportamento antissocial. Hoje, é percebida de maneira muito mais ampla, sob perspectivas que expressam fenômenos como a globalização e a exclusão social, os quais requerem análises que não se restrinjam às transgressões praticadas por jovens estudantes ou às violências das relações sociais entre eles. (ABRAMOVAY; RUA, 2014, p. 13)

Friso que para acontecer uma manifestação de violência não é necessário em si do uso de força excessiva ou agressão, ela pode ser simbólica. Tipo de violência velada, travestida na cultura e dada como natural, ela é

A mais profunda e estrutural modalidade de violência perpetrada pelo Estado cujo modus operandi se dá à sombra da permanente naturalização de seus objetos e/ou alvos, configurando o que se poderia chamar de um permanente "estado de violência", onde o que está em jogo não é a integridade física de indivíduos e/ou grupos, mas sim a integridade de sua participação cultural. (MENDONÇA, 1996, p. 2)

Segundo Bourdieu e Passeron, (1992), a desigualdade social nas relações é apontada como uma das origens estruturais da violência, o que contribui para manifestações da violência física, moral, simbólicas, favorecidas por impulsos que se expressam por meio de hábitos, costumes, tradições. A violência simbólica foi a principal forma encontrada na escola.

O problema da violência é notório pelas proporções inéditas que o fenômeno vem assumindo e se lançam na forma de preocupações e insegurança aos diretores, alunos, professores, pais e sociedade. Conforme Charlot (1997 apud ABRAMOVAY, 2003, p. 95), há três formas predominantes de violência no ambiente escolar: a violência na escola, da escola e contra a escola.

Violência na escola é aquela que se produz dentro do espaço escolar, sem estar ligada à natureza e as atividade da instituição escolar: quando um bando entra na escola para acertar contas das disputas que são as do bairro, a escola é apenas o lugar de uma violência que teria podido acontecer em qualquer outro local. Violência da escola esta ligada à natureza e às atividades da instituição escolar: quando os alunos provocam incêndios, batem nos professores ou os insultam, eles se entregam a violência que visam diretamente à instituição e aqueles que a representam. Essa violência contra a escola deve ser analisada com a violência da escola: uma violência institucional, simbólica, que os próprios jovens suportam através da maneira como a instituição e seus agentes os tratam (modos de composição das classes, de atribuição de notas, de 
orientação, palavras desdenhosas dos adultos, atos considerados pelos alunos como injustos ou racistas). (CHARLOT, 2002, apud ABRAMOVAY, 2003, p. 434, grifos meus).

Sem querer adentrar o assunto por menores, afirmo que estes três tipos de violência puderam ser reconhecidos na escola do Gama. Porém a que mais vivi e observei foi a violência na escola, ou seja, aquele tipo que não está ligada necessariamente à natureza das atividades escolares, mas que não deixam de ter reflexo nelas.

Divido os três tipos para ficar didático. Começo pela violência contra a escola, que conforme Charlot (2002) são os jovens que sofrem as violências por parte da instituição, especialmente pelos professores devido às faltas constantes, que geram muitos horários vagos; baixo envolvimento de alguns docentes nas atividades escolares; alta frequência de atestados médicos; remanejamento constante de horários, devido aos atrasos, dentre outros. Muitas alunas/os que conversei ainda apontaram alguns professores como grosseiros e distantes. Bourdieu e Passeron (1992) concordam que a própria ação pedagógica perpetua a violência por natureza, visto a imposição do conteúdo de cada disciplina ministrada, desconsiderando assim a origem e as peculiaridades dos alunos, quanto intensificando por vezes o poder que relação pedagógica exerce, por meio do autoritarismo.

Quanto à violência na escola, aquela na qual os assuntos ou os problemas que poderiam acontecer em qualquer outro espaço desenrolaram-se no colégio, esta localiza-se em praticamente todas as relações e materializa-se, em especial, por meio do bullying. Ouvi em campo, e por vezes presenciei, casos de brigas de alunos e alunas entre si. Brigava-se por tudo. Por causa de fofocas, de futebol, do lanche, das notas baixas, dos apelidos e por causa da tomada de objetos uns dos outros. Até mesmo um olhar fitado e mais demorado poderia ser visto como desrespeitoso e desafiador. Havia o uso e porte de drogas. Uma professora que sempre conversou comigo, mas pediu para não ser identificada, relatou: "Essa escola é muito violenta. Eles usam drogas na porta da minha sala. Antes eu ia na Direção, avisava que não ia 
dar aula para aluno drogado, inclusive esse aluno hoje tá no $\mathrm{CAJE}^{37}$. A gente sente medo de tudo" (DIÁRIO, 6 de setembro de 2016).

O bullying é uma categoria para analisar expressões de violência utilizada por pesquisadores europeus e hoje seu uso se expandiu. Esse fenômeno significa intimidação, brincadeiras pejorativas entre pessoas ou grupos que colocam em situação de vexame ou de constrangimento o receptor. Segundo Nancy Day (1996), ele é uma forma de violência simbólica (psicológica ou física) e pode ser denominado também de violência moral, de "violência de inferiorização do outro" ou "violência entre pares". Esta foi a prática se dirigia em especial contra meninas, negros e gays. Segundo Fernanda, a coordenadora, o bullying é a maior das violências por ali:

Fernanda: Aqui a maior violência seria a simbólica. O bullying aqui é muito forte, a questão de aliciação dos menores também é muito forte e a questão da sexualidade também.

Natália: Você está falando de gênero ou está falando de sexualidade, de florescer muito cedo assim?

Fernanda: De gênero. Existe certo preconceito também muito grande com relação à discriminação racial. (DIÁRIO, 25 de agosto de 2016)

O preconceito também se dá em métodos indiretos, como fofocas, manipulação de amigos, mentiras e exclusão de outros de um grupo, sem precisar existir uma palavra proferida. Muitas alunas/os afirmam que não existem preconceitos, mas brincadeiras. No entanto, certos apelidos situam-se na linha limítrofe entre brincadeira e agressividade.

Para Pereira (2006), a jocosidade e a ludicidade eram pano de fundo para este tipo de comportamento, pois muitas alunas e alunos sabiam que essas brincadeiras nem sempre eram amistosas, ao incorporar muitas vezes uma violência verbal que se servia do racismo, da homofobia e do machismo. Por vezes elas se transformavam em brigas, tanto de meninos quanto de meninas, o que atraía a atenção da escola inteira, que formavam uma roda para assistir.

37 CAJE - Centro de Atendimento Juvenil Especializado. Antiga unidade de internação de adolescentes em conflito com a lei, no DF, desativada em 2014. Entretanto, o termo pareceu como uma categoria nativa para denominar qualquer espaço que o jovem ocupe quando internado. 


\section{Composição 3}

Fotos de parede

II

Muitas práticas de bullying do dia a dia estavam

materializadas nas paredes. Como a sexualidade era uma das

manifestações mais recorrentes no campo, eles estavam sempre estampadas como desenhos, sejam de pênis, de vagina, ou simulando atos sexuais.

Junho, 2016.

Pichações sobre homossexuais, gordos e mulheres eram os mais comuns. Porém, em relação a elas, foi relatado que as próprias amigas é quem escreviam os "palavrões", diziam haver muita rixa entre as meninas da escola.

Junho, 2016.
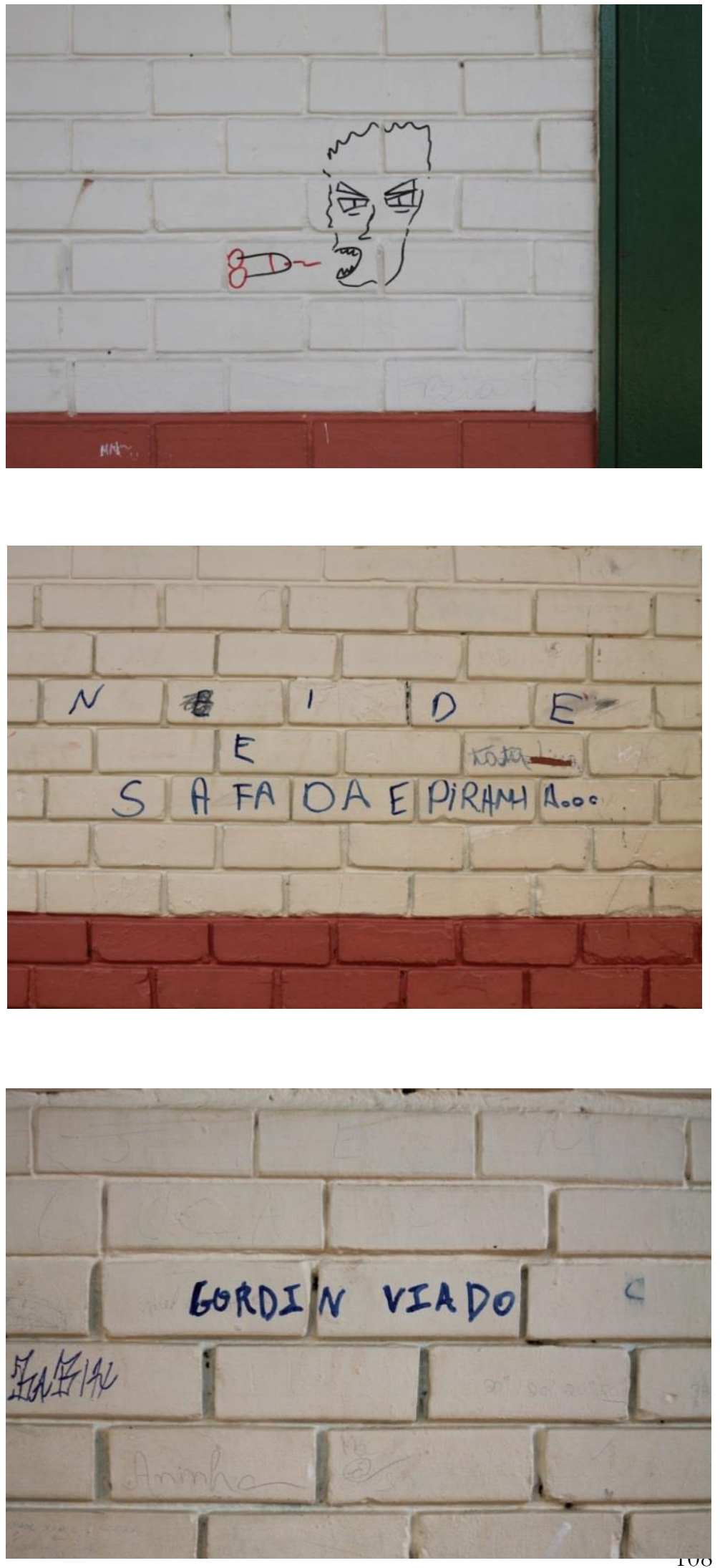
Ora, o aprendizado, a ludicidade, a sociabilidade, as amizades, as violências e os conflitos apareceram como pontos de vista importantes de alunos e professores, ora convergentes, ora divergentes, sobre a concepção de seu espaço escolar e suas dinâmicas relacionais. (PEREIRA, 2016, p. 135).

Por fim, a violência da escola partia dos alunos para com a instituição, às atividades escolares. Materializava-se nos xingamentos em sala, nas agressões verbais, nas ameaças feitas aos professores, e na destruição do patrimônio material do colégio. Frente a todos os problemas apontados, em uma entrevista na sala da coordenação, Fernanda - a orientadora e a "resolve" tudo da escola, desabafou:

Fernanda: (...) A escola não tem capacidade nem física nem psicológica para atender todos estes alunos. Nós não temos. Eu falo [estrutura] física porque nós não temos nem uma portaria. Vou começar com o mínimo. Então entra aqui quem quer e quem não quer. Então um menino se ele falar que vai entrar armado, ele vai entrar armado. $\mathrm{E}$ se você restringir a entrada dele, ele vai pular o muro. E quem vai segurar? (...) Então assim, eu acho que a escola não tem condições. Eu falo isso porque nós não temos uma equipe preparada nem de segurança, nem de portaria, nem sistema de câmera, nada. Nós somos uma equipe assim, tentando abraçar uma causa de olhos vendados. Eu considero que nós somos uma escola cega no meio de uma comunidade injusta.

Natália: Nossa! Sério isso, né.

Fernanda: Eu, particularmente acho. Eu falo injusta porque é uma comunidade muito carente que precisa e a gente está aqui tentando ajudar só que tem muita gente de fora que quer fazer um comércio aqui dentro, comércio de drogas, comércio de armas. Então o que acontece? Aqui é um campo fértil pra isso. (DIÁRIO, 25 de agosto de 2016)

Como uma tentativa de resolver as questões mais sérias que se apresentavam, e conhecendo o fato que alguns alunos já não tinham mais medo das punições escolares, que eram as advertências, as reuniões com os pais, as suspensões, transferências ou expulsões, Fernanda, por duas ou três vezes que estive lá, acionou a polícia militar. Com o intuito de coibir o uso de drogas, mas para ajudar em outras tarefas também, a polícia "sempre tinha algum tipo de participação na escola" (PEREIRA, 2016, p. 107). O fato parecia ser "natural", visto que os policiais paravam o carro ao lado da cantina no estacionamento interno e ninguém parecia se incomodar. Entretanto, percebi que as opiniões variavam. Assim, alguns entrevistados defendiam a presença da polícia ali para conter a criminalidade dentro ou ao 
redor da escola. Outros afirmavam que a escola deveria resolver seus problemas sozinha. Segundo a orientadora, a polícia não estava na escola constantemente,

"É só quando a gente pede. Quando a gente está com alguma informação gritante, tipo quando uma mãe vem aqui e fala 'meu filho está andando com fulano de tal, com droga, então eu quero que faça uma averiguação'. Aí quando acontece isso, que eu chamo de 'varredura', a gente precisa isolar os portões, aí o carro de polícia entra. Nós não podemos abrir mochila de ninguém. (DIÁRIO, 25 de agosto de 2016)

Encontro-me imensamente com dois temas que Pereira (2016) delineia muito bem em seu livro. Como nos campos que ele pesquisou, neste aqui há a confluência entre a autoridade e a alteridade. A autoridade escolar, observada aqui em diversos momentos, tanto no esquema hierárquico dos cargos quanto nas relações do cotidiano, esta "revelou-se uma chave importante para pensar muitos dos conflitos e problemáticas que a escola apresentou. Crise de autoridade institucional ou novas formas de exercício do poder, da disciplina e do controle?” (p. 31). Esta é uma pergunta que também me coloquei.

A alteridade, cara aos antropólogos, e ligada às produções e afirmações das diferenças, "parece estar cada vez mais distante do mundo escolar, afinal as escolas parecem estar ignorando as múltiplas alteridades que surgem em seu meio, em especial, nas brincadeiras, nas implicâncias, nas conversas, até mesmo na indisciplina (PEREIRA, 2016). Onde se posiciona a tarefa da escola de ajudar o aluno a se desenvolver em meio a diferença? Parece não haver espaço para isso.

Para finalizar, gostaria de explicar o título deste tópico. Ele surgiu de modo inesperado:

Numa tarde de junho, aproveitei que tinha chegado bem cedo à escola, e montei minha máquina fotográfica. Saí pela escola me permitindo um exercício diferente: imaginarme fotógrafa, pensar os enquadramentos. O que de interessante poderia surgir? Já havia um tempo que eu estava a fim de fotografar as pichações que eu via na escola, penso que elas informavam muita coisa sobre a adolescência, sobre a vida escolar. Quem sabe não rende um ensaio? Pensei. Enfim, fui andando pelos corredores e observando tudo atentamente. Fotografava quando achava algo legal. Foi então que um garoto gritou para mim da janela de sua sala "Tá doida, tá tirando foto de parede!?". Acenei e sorri. E andei. E fotografei mais. (DIÁRIO, 23 de junho de 2016) 
A fala desse jovem deu nome à seção. Para muitos poderia ser apenas fotos de paredes, algo beirando a loucura, confesso ter me sentido desconfortável naquele momento, pois outras pessoas também me questionaram. Mas no fundo, era um olhar inédito que eu me permitia e trazer aquelas imagens para o texto, como caminho para compreender mais as relações de campo, foi o que me manteve na missão. Espero ter cumprido isso.

\section{Entre cenário, personagens e vacina}

A intenção maior deste capítulo foi a de conhecer as dinâmicas juvenis daquela escola e pensar em como elas poderiam contribuir à pesquisa da vacina. Alguns questionamentos iniciais me surgiram ao compor o capítulo: Por que falar de cenário, físico ou recôndito, é importante num contexto de saúde? Por que explicitar as violências entre as relações interpessoais é válido? Mas o que isso tem a ver com a pesquisa? Isso influenciou aos dados de alguma forma?

Seguindo os passos de Peirano (2014), concordo que a etnografia não tem modelo prédefinido e nem momento certo para começar e acabar. Todos estes dados apresentados, desde o início, já fazem parte e compõem a análise do processo vacinal em si. Creio, assim como a autora, que a "empiria - eventos, acontecimentos, palavras, textos, cheiros, sabores, tudo que nos afeta os sentidos - é o material que analisamos e que, para nós, não são apenas dados coletados, mas questionamentos, fonte de renovação" (p. 6). Apresentar este recorte sócio espacial me permitiu isso.

Ser fiel à realidade encontrada e percebida em campo é importante, pois valida ou exemplifica, outras questões que se apresentarão ao logo do trabalho, como o possível distanciamento do olhar da escola frente às questões de saúde, a "zoação" constante no dia da vacinação, a estreita relação entre saúde e religião, os tabus para se tratar sobre sexo, dentre outros assuntos. Pontualmente, falar do grupo pesquisado, descrevendo o lugar em que ele estava e suas relações, amistosas ou não, é relevante por ser mais um ângulo de análise dos dados e fatos encontrados. É ganhar experiência ao lidar com uma intersecção de objetos e de significados. E mais, enquanto pesquisadora me tornei mais sensível a muitas questões que 
parei raramente para analisar, como os tipos de violências no ambiente escolar. Tive "nesse momento" meu instinto etnográfico acionado (PEIRANO, 2014), a violência escolar, e tudo mais sobre a escola, não deixa de ser um fenômeno de sociedade (OHSAKO, 1997; CHARLOT, 1997), por isso não poderia deixar de tratar aqui, como parte do cenário que a vacina e eu encontramos na escola.

Por falar em violência, reforço um apontamento precioso feito por Pereira (2016), onde ele diz haver uma associação entre juventude e criminalidade quando se trata de periferias e de classes populares. Quase sempre nos trabalhos que utilizei como referencial, ou na busca por dados escolares ou regionais, era dado o enfoque da criminalização dos jovens pobres, o que demonstra que tal "associação tende a conformar uma concepção específica sobre esta juventude, ligada a ideias de carência e vitimização, mas também a crime e violência” (2016, p. 25). Frente a isso, meu viés foi procurar dizer que estas questões apenas evidenciam o quanto o assunto é complexo e não pode ser estereotipado, como se viu nas falas das interlocutoras/es.

A violência pôde ser muito mais percebida como "uma categoria lúdica acionada pelos jovens, mesmo sem terem envolvimento com a criminalidade em si, como forma de gozação ou mesmo de intimidação dos docentes" (PEREIRA, 2016, p. 25). Este estereótipo acaba por comprometer o que deveria ser a identidade da escola, lugar de disciplina, de cuidado, de atenção, inclusive com a saúde dos alunos e jovens. Quando se tem uma escola violenta, em certo sentido, o olhar pedagógico pode se voltar a essas questões que de fato precisam de uma resposta mais imediata, acabando por priorizá-las em detrimento de outras.

Por último, este capítulo ajuda os que seguem no sentido de localizarmos o local e para que tipo de público se abriu para a campanha do HPV. Escola e adolescentes são os partícipes maiores do mundo social do HPV, por isso falar tanto deles. A vacina entrou nesse cenário. Entrou nessas relações. Mas há outros tons. Ela encontrou uma escola que lhe acolheu, profissionais que trabalharam para que ela acontecesse, deparou-se com muitas meninas e meninos que a valorizaram. Assim, dois caminhos de análise para a vacina dentro da escola se abriram. Um de ida, no sentido de usar a escola para entender os contornos da política de vacinação do HPV. E um caminho de volta, quando é o próprio HPV e sua campanha, usado para se entender o papel "formador" da escola. Ambos se complementam. Irei explorar isso no próximo capítulo. 


\title{
Capítulo 3. O DIA DA VACINAÇÃO
}

Como alojamento de vida

Que Deus cria no mundo.

Por isso as boas amigas

Tomam de gosto profundo

\begin{abstract}
A nossa Enfermeira Nivonete
$E$ as nossas Agentes de Saúde,

Maria e Terezinha merecem

Parabéns por sua boa virtude.
\end{abstract}




\section{Contextualizando o dia}

Desde o segundo semestre de 2013 a escola do Gama recebia a visita do centro de saúde designado para vacinação das meninas contra o HPV. Isso ocorria, à época, com a frequência de duas a três vezes ao ano, a depender das doses preconizadas. A cada novo ano, os profissionais de saúde voltavam à escola para vacinar as meninas que entravam na faixa etária desejável da campanha ou para complementar a vacinação com a segunda ou terceira $\operatorname{dose}^{38}$ de quem faltasse. Assim a vacinação foi acontecendo.

Este dia que proponho contar ocorreu em três de junho de 2015, momento em que aconteciam as últimas visitas da vacina às escolas, visto que dali em diante, elas seriam apenas aplicadas nos centros de saúde, o que marcava seu retorno a sua área institucional "natural". Esta alteração estava acontecendo ou já tinha acontecido em outras cidades do DF, devido às mudanças tanto na política distrital da vacina HPV, quanto nas alterações feitas no calendário de vacinação oficial ${ }^{39}$.

Vendo a possibilidade de perder a chance de estar presente em um dia como o da vacinação, antecipei a minha entrada na escola em um ano, observando o fenômeno antes de ter conhecido a escola, as pessoas, o sistema de ensino. Ainda não trabalhava com a câmera fotográfica nesta época, por isso a etnoficção nas fotos, abordada na introdução. Mesmo com a sensação de estar pulando fases, eu sentia que precisava estar presente naquele dia de

\footnotetext{
${ }^{38}$ Vale recordar que "No DF, a vacina contra o HPV foi aplicada em três doses, que deveriam ser tomadas em escolas públicas, privadas ou em postos de saúde. A primeira dose será em março; a segunda, em maio; e a terceira, em setembro. Nos demais estados, as meninas receberão a primeira dose em março; a segunda, seis meses depois; e a terceira, daqui a cinco anos. (CONITEC, 2013)

${ }^{39}$ Comentei sobre o calendário oficial de vacinação no capítulo um. Em 2016, ele passou por algumas mudanças, o que incluiu a diminuição das doses da vacina HPV para duas:

Os postos de saúde de todo o país já estão com novo calendário de vacinação para 2016. Estão sendo alteradas doses de reforço para vacinas infantis contra meningite e pneumonia, além do esquema vacinal da poliomielite e o número e doses da vacina de HPV, que não será mais necessária a terceira dose. As mudanças, realizadas pelo Ministério da Saúde, começaram a valer a partir dessa segunda-feira (04/01/16). "Essas mudanças são rotineiras. O Calendário Nacional de Vacinação tem mudanças periódicas em função de diferentes contextos. Sempre que temos uma mudança na situação epidemiológica, mudanças nas indicações das vacinas ou incorporação de novas vacinas, fazemos modificações no calendário", explicou o secretario de Vigilância em Saúde, Antônio Nardi. (BRASIL, 2016)
} 
vacinação, não apenas por ele ter a possibilidade de não se repetir ${ }^{40}$, mas por ter se configurando um feeling antropológico para mim. E, de fato, este dia iluminou-me as questões que gostaria de entender com mais detalhes em campo. Por isso o nome do capítulo "O Dia da Vacinação". Este dia vale um espaço de destaque devido às novidades, estranhamentos, interesses e complexidades que este ele abriu para a pesquisa. Sem esquecer-me dos atores sociais que pude conhecer, os quais delinearam e fizeram viver o mundo social do HPV. Assim, este capítulo será dedicado ao contexto, cenários e pessoas presentes no dia em que ocorreu a vacinação que presenciei na escola do Gama.

Entretanto, gostaria de frisar que não me refiro aos fatos que apresentei ao longo do capítulo como aqueles que aconteceram apenas no dia da vacinação. Uma trama social desenrolou-se antes e depois deste dia. Como por exemplo, as negociações para a vacina entrar na escola aconteceram anteriormente, desde 2013, bem como algumas reverberações sobre o HPV ocorreram depois da vacinação (mostrarei quais adiante). Não há como delimitar este fenômeno (vacina HPV) a um dia específico, isto é certo, portanto a ideia deste capítulo foi mesmo de tirar uma "fotografia" do dia, retratar um momento e contar sobre aquela “imagem”, falar dos fatos ali ocorridos. Penso não haver como determinar (e eu não tentaria) um começo e um fim para o processo vacinal nesta escola. Afinal, ele "começou" em 2013 e encontrava-se em aberto, pois ainda havia cartazes divulgando a vacina e, no mínimo, ele estava vivo na memória das pessoas, como pude constatar. Este foi apenas um micro momento vacinal que presenciei, porém, muito reverberante. Feitas estas considerações iniciais, sigamos.

Luz, câmera, ação. Cheguei à escola do Gama às 13h. Era um dia quente, mês de junho, tempo seco em Brasília. Era a minha primeira visita, estava um pouco tímida, não conhecia ninguém, exceto minha mãe. Encontrei-me com ela no estacionamento dos professores e ela me ajudou na tarefa de procurar a coordenadora da escola, a Fernanda, para que eu pudesse me apresentar. Ao encontra-la em sua sala, minha mãe nos deixou sozinhas. Ela me convidou para entrar na sala da Direção, dizendo algumas vezes que eu parecia muito com a minha mãe (esta comparação sempre existiu e foi comigo durante todo o campo), e se

\footnotetext{
40 Este dia poderia não ocorrer de novo na escola porque a vacinação estava retornando aos centros de saúde. Para tomar qualquer dose da vacina HPV, as alunas deveriam ir a um posto. Por isso, em alguns momentos do texto, chamo este dia de "Dia D", em alusão a sua importância etnográfica.
} 
sentou por alguns instantes comigo para explicar como seria a visita do centro de saúde ${ }^{41}$ naquele dia. Depois disso, disse que eu poderia ficar a vontade na escola, até a hora que o "pessoal da vacina" chegasse.

Andei um pouco pelo colégio, conheci o espaço, conheci algumas pessoas e depois segui para uma das salas de aula - sétimo ano. Esta era uma das turmas que receberia a vacinação aquele dia, e foi uma sugestão da minha mãe, devido as alunas/os serem mais interessados e participantes, afinal, eu queria sentir o "clima" antes da vacinação, se havia comentários, expectativas. Já em sala e com a permissão da professora de História, percebi que não havia alvoroço, quer dizer, não por causa da vacina, pois os meninos e as meninas conversam muito sobre outros assuntos, enquanto se ajeitavam em suas cadeiras e pegavam o caderno para copiar o que estava no quadro.

Acomodei-me no canto direito da sala, na fileira rente à parede e aproveitei a conversa que dominava o ambiente, para conhecer algumas garotas que se mostravam mais abertas e simpáticas. Apresentei-me como pesquisadora, que estava ali para conhecer mais sobre a vacinação do HPV. Ao saber disso, elas começaram a fazer perguntas acerca da vacina para mim: "Vai doer?”, “Essa é a última dose?”, “É para que mesmo?”. Eu tentei explicar que não era da área da saúde, que não sabia muito sobre a vacina em si, mas gostaria de saber como a vacinação estava ocorrendo na escola. Várias meninas se mostraram interessadas em conversar. Uma delas disse que, uma semana antes, foram avisadas que iria acontecer a vacinação e que deveriam trazer o cartão de vacina, apenas. Outra menina me disse que era segunda dose dela, mas estava com medo, pois a primeira doeu muito. E seguimos conversando.

Então a professora perguntou em voz alta: "Gente, quem aqui vai tomar a vacina do HPV hoje? A pesquisadora ali quer saber...”. Foi um burburinho na sala. Todo mundo queria falar. Notei que muitas meninas já tinham completado as três doses, afinal, na sala tinham meninas com 13 anos ou mais - data limite para a vacinação na rede pública contra o HPV. Assim, por meio da pergunta da professora, comecei um diálogo mais longo e detalhado com outras meninas, as quais se aproximaram para contar suas histórias.

Em meio à conversa muito atenta que estava tendo com elas, um item nelas me chamou bastante atenção. Não pude deixar de observar que "as meninas usavam muita

\footnotetext{
${ }^{41}$ Volto a usar CS por extenso para marcar bem a figura e presença do centro de saúde.
} 
maquiagem, era batom, era lápis de olho, era rímel, era blush, até base algumas tinham” (DIARIO, 03 de junho de 2015). Isso me impressionou, pois o batom estava muito bem passado, o rímel, então. As maquiagens as deixavam muito bonitas, mas o fato de terem pouca idade para aquilo tudo, na minha concepção, me fez pensar uma série de fatos depois. Eram alguns imperativos da adolescência, como vaidade, feminilidade, sexualidade, muito discutidos no capítulo dois, que poderiam estar atuando naquele momento. Mas para não interromper a narrativa e por não ser o foco do assunto, não adentrarei nos detalhes. Relato isso como mais uma forma de descrever as interlocutoras e relembrar o que se vê muito nas fotos, o batom.

Uma garota, Isabela, de 13 anos, negra, cabelos enrolados, presos num coque com uma fita e com um batom lilás (bem luminoso), foi a minha primeira interlocutora em campo. Ela me contou que morava no Gama e já tinha tomado todas as doses da vacina na escola. Contou que ficou sabendo da vacinação porque a coordenadora passou nas salas explicando sobre a vacina, avisando o dia que o posto vacinaria na escola. Ela contou que levou um comunicado para casa, o qual avisava sobre a vacinação, e sua mãe prontamente concordou, enviando o cartão de vacina que este solicitava. Ela comentou também que sua mãe apenas disse que ela deveria tomar a vacina, pois "protegia" o corpo. Nesta sala de aula, ainda conversei com outras garotas, que me contaram fatos muito parecidos ao de Isabela. Nisso, me chamam à porta, estava na hora da vacinação.

A vacinação estava ocorrendo na sala da coordenação. Segundo me explicou a coordenadora, "estas são salas com mais espaço, mais reservadas, tem pia, tem torneira, tem mais estrutura para o pessoal da saúde”, disse ela. Esta personagem que tanto falo teve um dos papéis principais na vacinação contra o HPV, pois, dentro da escola do Gama, era ela quem estava a cargo do processo vacinal. Fernanda era negra, tinha por volta de 42 anos, era formada em Biologia, era casada e tinha dois filhos. Nascida em Brasília, trabalhava na Secretaria de Educação há três anos, sempre nesta mesma escola. Antes, foi professora em uma escola particular, até que passou no concurso da fundação ${ }^{42}$. Inicialmente, foi Fernanda que negociou a entrada da vacina na escola com a Secretaria de Saúde, preparando toda a papelada necessária.

\footnotetext{
42 "Fundação" é um nome nativo e muito comum para se referir à Secretaria de Educação do Distrito Federal.
} 
Assim, por meio de reuniões, papéis, documentos oficiais e telefonemas, de modo burocrático e pontual, que a entrada da vacina neste ambiente escolar se deu. Falo em burocracia querendo trazer à luz o conceito de Weber (2011) que diz ser o termo empregado para indicar funções densas da administração pública, guiadas por normas, atribuições específicas, esferas de competência bem delimitadas e critérios rígidos quanto à atuação de funcionários. Cada pessoa envolvida no processo vacinal tinha suas atribuições estipuladas, as normas de aplicação da vacina (as diretrizes da campanha) estavam dadas, o papel do centro de saúde (aplicador da dose) e do centro de ensino (organizador e disseminador de informações) também. De fato, a vacinação pareceu seguir essas prescrições burocráticas.

O primeiro contato entre a escola e o serviço de saúde foi por meio de um documento oficial enviado pela Coordenação Regional de Ensino - CRE (da região administrativa onde se localiza a escola), o qual convocava o diretor ou outro membro da escola a comparecer a uma reunião geral que determinaria as regras quanto à vacinação do HPV. No caso da escola do Gama, Fernanda foi a pessoa escolhida pela Direção para representar a escola e obter as informações necessárias. Estas regras diziam respeito quanto à divulgação da campanha, faixa etária que seria vacinada, marcação do dia para a visita do centro de saúde, entrega de cartazes publicitários, confecção da lista de meninas que seriam vacinadas, dentre outras regras e solicitações. Algumas vezes, esse contato inicial também poderia ser feito pela vigilância epidemiológica da cidade ou diretamente pelo centro de saúde da região responsável pela vacinação na escola pré-determinada, isso no início da campanha no DF, em meados de 2013. Desta negociação até minha chegada à escola, passaram-se dois anos e meio.

\section{Foto 4}

Registro da papelada na sala da Direção. Elas abriram as portas da escola para a vacina.

Dezembro, 2015.

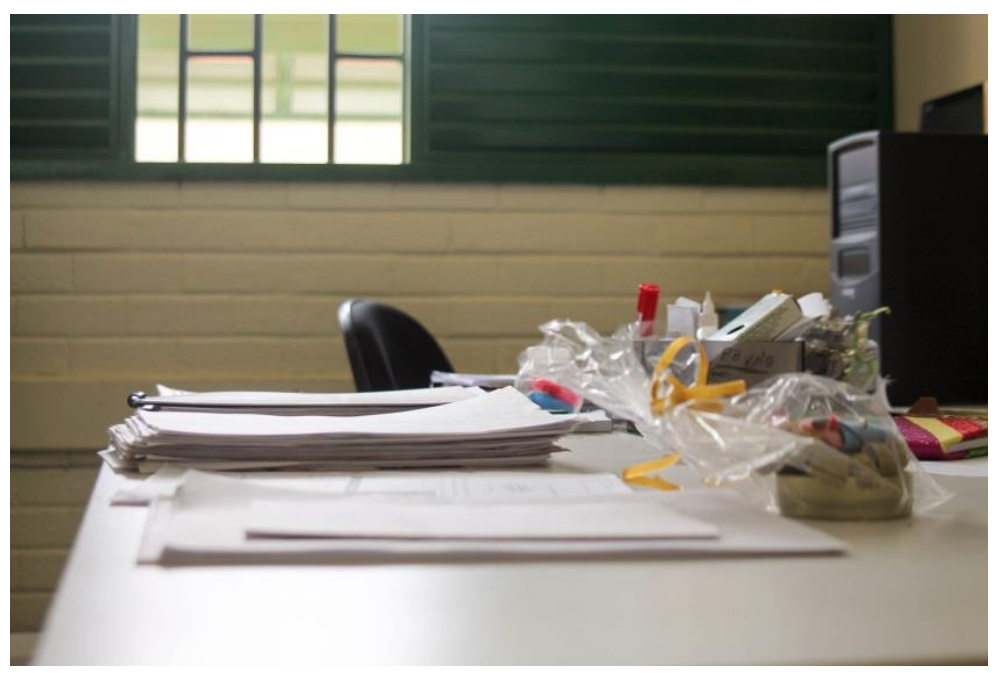


Fernanda contou que, após as combinações sobre a realização da vacinação com o centro de saúde, a escola teve um tempo para se organizar, quanto a uma data disponível (de preferência, sem eventos na escola) e também para confeccionar a lista das meninas que seriam vacinadas, de acordo com a faixa etária e tipo de dose (primeira ou a segunda dose). A cargo da escola também foi solicitado que procedesse a divulgação da campanha de vacinação, mas o tipo de meio ou informativo não foi especificado, cada escola poderia adotar a política que desejasse, porém era sugerido que o tema HPV fosse trabalhado na disciplina de Biologia.

Sendo assim, a coordenadora Fernanda, junto à supervisora pedagógica, Karen, decidiram que a própria Fernanda ficaria responsável em repassar os avisos em sala de aula sobre a vacinação, e ainda, lembrar às meninas de trazerem seus cartões de vacina e os termos de recusa assinados pelas mães e pais, caso estes não permitissem a vacinação das filhas, "O pessoal do posto entregou o termo negando, de recusa, para gente tirar xerox, eles só me deram uma cópia e eu ia entregando caso as meninas precisassem” (DIÁRIO, 25 de agosto de 2016). Fernanda contou que a escola achou melhor se precaver por escrito quanto à autorização ou não dos pais em relação à vacinação das filhas, para que depois não tivessem qualquer tipo de problema. Fernanda relatou ainda que tentava ser direta sobre a vacina: “Olha, o HPV é uma DST, é transmissível e agora tem vacina”. Propositalmente não queria entrar nos pormenores sobre a transmissão por via sexual.

A sala da coordenação, que recebeu a vacina no dia " $D$ ”, era de fato grande. Possuía uma mesa de reunião no centro, com cadeiras e um sofá ao redor dela. Havia também armários e estantes de aço encostados em uma das paredes da sala, ao lado, vários computadores, do outro lado, uma pequena copa, com pia de granito, bebedouro e frigobar. No dia da vacinação, encontrei sentados à mesa, Raul e Tereza, os dois técnicos de enfermagem do centro de saúde que iria vacinar as meninas da escola. Fernanda também estava por lá, e havia outro servidor, o André, coordenador de apoio. André trabalhava na escola desde 1996 e era um dos servidores mais antigos. Nascido e criado no Gama e "bem casado", como ele disse, era pai de três meninas, uma adolescente de treze anos (vacinada contra HPV) e duas gêmeas, de quatro anos. Ele não quis revelar sua idade. Era formado em Administração com complementação pedagógica em Matemática e já tinha sido professor daquela escola, mas devido ao quadro de estresse que desenvolveu, a escola preferiu retirá-lo de sala de aula e colocar-lhe como 
coordenador de apoio - cargo "criado" pelo diretor. Ele estava na sala, no dia da vacinação, assessorando Fernanda.

Enquanto as meninas iam chegando e formando uma fila (que já saía da sala), eu aproveitei para me acomodar à mesa, à direita de Raul, que estava ocupado lendo a lista das meninas que a escola tinha lhe entregado. Pedi um minuto da atenção deles para apresentar a pesquisa e pedir autorização para acompanhar o trabalho naquela tarde, o que foi aceito sem resistência ou perguntas. Ainda não sabia, mas Raul seria uma das peças importantes na pesquisa, junto à Fernanda. Raul era branco, era de Minas Gerais e tinha 49 anos. Técnico de enfermagem, era casado com uma servidora aposentada da área de saúde. Tinha dois filhos, um de vinte anos e o outro de dezessete anos. Ele possuía muitos anos de serviço na secretaria de saúde e disse "gostar muito do que fazia". Vi em Raul uma pessoa calma, gentil e simpática. Ele era legal com todos, sempre respondia todas as perguntas que as meninas faziam, tinha “jeito”, era paciente. Ele foi meu interlocutor principal nas visitas ao centro de saúde. Tive a oportunidade de estar com ele três vezes depois deste dia.

Tereza, a dupla da Raul, era branca, magra, brasiliense, com mais de 40 anos. Neste dia já pude notar que ela era introvertida e menos paciente que Raul, mas isso em nada atrapalhava o entrosamento entre eles, à primeira vista. Apenas estive com ela em dois momentos, nesse dia e uma vez no centro de saúde, quando fui entrevistá-los. No dia da vacinação, os dois dividiram as tarefas. Enquanto Raul preenchia os cartões de vacina anotando as doses, conferindo os nomes e completando os dados das meninas na lista da escola (e por tabela, acalmava as meninas), Tereza preparava e aplicava as vacinas, sem muita conversa.

A essa altura, a vacinação já ocorria “a todo vapor”. As meninas iam se organizando por ordem de chegada, um pouco receosas pelo medo da vacina, pela dor que possivelmente iriam sentir. Conversavam entre si, umas se acalmando, outras, fazendo medo nas colegas. Fernanda estava sempre presente, organizando a fila, pedindo silêncio, incentivando as meninas. Porém, aos poucos, a sala foi perdendo a ordem, foi ficando barulhenta e tumultuada. Enquanto eu observava Raul, via as meninas sendo vacinadas, tentava acompanhar as conversas paralelas, algumas garotas iam se sentando ao meu lado, para conversar, para perguntar o que eu fazia ali, até mesmo tirar alguma dúvida em relação à vacina. 
Havia um "ritual" para a vacinação. Após a fila, quando a menina se aproximava da mesa, Raul logo perguntava por seu cartão de vacina. Se não tinha, ele perguntava em qual dose a menina estava e procedia preenchendo um novo cartão. Reparei que o cartão do HPV era cor-de-rosa (padrões de gênero atuando) e que deveria ser afixado junto ao cartão de vacina que estivesse em casa. Este novo cartão deveria ter o nome da adolescente, o endereço, o dia que recebeu a vacina, a dose ministrada e também a data da próxima dose. Raul sempre recomendava que as meninas entregassem o cartão para à mãe ou responsável e não se esquecessem de retornar ao posto para tomar a dose seguinte. Depois disso, ele fazia a checagem do nome daquela adolescente na listagem da escola, se não encontrasse, procedia anotando seus dados abaixo da folha, como complementação.

Neste caso, por dois motivos o nome da jovem poderia estar fora da lista: a) Fernanda confeccionou a lista apenas com os nomes das meninas que iriam tomar a primeira dose, logo, se uma garota alegasse estar na segunda ou terceira dose, não estaria relacionada nela; b) Fernanda alertou Raul que algumas meninas se escondiam para não serem vacinadas, ocasionando falhas na listagem. Este último item pode ser ratificado por Débora, uma das meninas que conversei na sala de vacinação aquele dia:

Enquanto eu observava todo esse processo, uma garota, de uns 12 anos, Débora, senta ao meu lado e me pergunta se estou escrevendo um livro. Dou uma risada, digo que não, mas que preciso escrever muito, pois estou fazendo uma pesquisa. Ela era negra, cabelos cacheados, baixinha. Conta que está com medo da vacina, pois ela é guarda mirim e tem receio de ficar com o braço dolorido e não conseguir bater continência. Perguntei se ela queria tomar a vacina e após a confirmação com a cabeça, sugeri que tomasse no braço esquerdo, para não correr o risco. (...) Ela mesma disse, acompanhada de mais duas colegas, que não estava na lista que a escola fez, porque ela fugia da vacina, fugia por medo da dor (...). (DIÁRIO, 03 de junho de 2015)

Raul então solicitou à Fernanda que fizessem rapidamente um novo levantamento nas salas, mas desta vez, chamando as meninas para a segunda e terceira dose. Ela procedeu ao pedido. Em alguns minutos, a sala de vacinação estava cheia novamente. Enquanto as meninas chegavam, eu ainda conversava com Débora, e não pude deixar de notar que havia alguns meninos espremidos na janela, uns espiando a vacinação, outros fazendo brincadeiras com as colegas e sorrindo. Estas respondiam a eles ou silenciavam. 
Raul, em certo momento, se mostrou interessando em saber como a escola trabalhou a vacina, pois as meninas lhe faziam muitas perguntas: "Para que é essa vacina mesmo?", “Tenho que tomar de todo jeito?”, "Quem já tomou as três doses tem que tomar mais?”. Então, em certo momento, ele fez a seguinte pergunta alto na sala: "O professor de ciências fez algum trabalho com vocês sobre pra que é a vacina?”. Elas responderam: "Não". Ele disse: "Uma pena, perderam uma grande chance de fazer um bom trabalho". Ele comentou com Tereza que depois iria checar isso com Fernanda, pois "eram muitas meninas desinformadas". Nisso, uma das garotas perguntou a ele: “Tio, tenho mesmo que tomar isso?”. Ele respondeu: “É bom, é bom para você ficar uma moça protegida”. Tereza completou a ideia com ironia: “Gostei do processo dessa escola, tipo 'entra aí e toma a vacina'. Parece que eles não avisaram as meninas mesmo" e ele respondeu: "Não é possível, Tereza!" (DIÁRIO, 03 de junho de 2015). Raul se mostrou preocupado com as meninas, tentava explicar para elas sobre a vacina, mas sabia que esta era uma atividade da escola, e precisava dar andamento à vacinação. Então pareceu conformar-se.

Feita a identificação oficial por Raul, pois o cartão de vacina é um documento do Estado, era a hora da aplicar a vacina. Com a injeção à mão, Tereza orientava que a menina se acalmasse, ficasse sem se mexer e respirasse fundo. Havia um pânico sobre a dor que vacina causava. Em quase todas as conversas que tive, as meninas relataram sofrer, pois a vacina doía demais. Até mesmo mensuravam a dor de acordo com cada dose, sendo a terceira como a mais dolorida. Neste dia, foi um alvoroço, pois algumas meninas "faziam cena mesmo, gritavam, se jogavam em Tereza, outras, de tão nervosas, nem respondiam direito ao que Raul lhes perguntava” (DIÁRIO, 03 de junho de 2015). Raul às vezes sorria por causa do “drama” delas, me olhava, observava meu anotar e continuava: "próxima menininha!". Com a vacina tomada, as meninas podiam retornar à sala de aula. E assim, o "ritual” acontecia para cada uma.

Falo em ritual com a intenção de utilizá-lo à luz das noções de Mariza Peirano (2006). Segundo Peirano (2006), o ritual deixa de ser um objeto e passa a ser um meio de abordagem teórica.

Em princípio, passa a ser "ritual" o que nossos interlocutores em campo definem ou vivem como peculiar, distinto, específico. (...) Eles possuem certa ordem que os estrutura, um sentido de acontecimento, de propósito coletivo. (...) eles não se separam de outros comportamentos de forma absoluta, eles simplesmente replicam, repetem, enfatizam, exageram ou acentuam o que é usual. (2006, p. 10) 
Os apontamentos feitos pela autora podem ajudar a pensar a vacinação enquanto um ritual da sociedade contemporânea. Adrianne Rodolpho (2004) complementa a ideia de Peirano (2006), ao frisar que os rituais conferem noção de coesão social ao grupo:

Nesse sentido, os rituais concedem autoridade e legitimidade quando estruturam e organizam as posições de certas pessoas, os valores morais e as visões de mundo. Dizemos que os rituais emprestam formas convencionais e estilizadas para organizar certos aspectos da vida social. (...) Ora, as formas estabelecidas para os diferentes rituais têm uma marca comum: a repetição. Os rituais, executados repetidamente, conhecidos ou identificáveis pelas pessoas, concedem certa segurança. Pela familiaridade com a(s) sequência(s) ritual (is), sabemos o que vai acontecer, celebramos nossa solidariedade, partilhamos sentimentos, enfim, temos uma sensação de coesão social. (RODOLPHO, 2004, p. 139)

Assim aconteceu com a vacina do HPV nesta escola. Neste dia da vacinação, três garotas comentaram comigo que aquilo ali "parecia um ritual", era uma vivência distinta para elas, claro que guardadas as ressalvas conceituais, elas se referiam a palavra "ritual" como uma sequência de ações ordenadas e padronizadas, que se repetiam. Mas, além disso, pude pensar a vacinação com outras marcações, como os rituais parecem fazer com a vida social. A vacinação separava homens e mulheres quanto a quem deveria ou não se vacinar; marcava a chegada de uma menina na idade específica da vacinação; impunha o poder da escola e do sistema biomédico sobre os corpos (autoridade); permitia o compartilhamento dos sentimentos, sejam eles de dor ou medo entre os pares; diferenciava as meninas protegidas das não protegidas; as medrosas das corajosas (valores morais); os corpos obedientes dos desobedientes, porquanto "os rituais revelam visões de mundo dominantes ou conflitantes de determinados grupos" (2006, p. 11), não configurando-se em meras formalidades. Chamaria a vacinação por ritual de passagem, devido a marcação desses apostos.

Por fim, foi por meio deste "ritual" que pude conhecer as visões de mundo que rondaram o processo do HPV. Gostaria de frisar que nos eventos que nos parecem corriqueiros, há uma série de elementos para estranhar e remontar. E a vacinação é um deles. Assim a tarde foi passando. Ocorreu de algumas meninas serem seguradas para tomar a vacina, não porque não quisessem, mas porque estavam com tanto medo e dando tanto trabalho, que Tereza pediu à Fernanda que as segurassem. Gritos, por vezes risadas, ou choros, foram ouvidos. Em meio a essa situação, com a sala bem cheia, Raul, tendo que se dividir entre 
acalmar as meninas, preencher os cartões e completar as listas, pediu que elas próprias preenchessem seu cartão de vacina. Mesmo aquelas meninas que não estavam na lista, não tinham trazido o cartão, tomaram a vacina.

Passada a vacinação, Raul sentou-se junto à Fernanda e os dois começaram a contabilizar as meninas vacinadas. Entre as que estavam na lista e as que foram anotadas à parte, eles haviam vacinado por volta de quarenta e três meninas. A lista estava repleta de nomes, doses e datas. Fernanda pediu a ele para tirar uma cópia, caso houvesse necessidade de checar algum dado posteriormente. Eu agradeci a todos eles a oportunidade de passar aquela tarde ali. Raul ainda me passou o telefone do centro de saúde, caso eu precisasse de mais alguma informação. Com pressa e aparentemente cansados, os dois se despediram de mim e de Fernanda e partiram levando seus pertences, as caixas com o restante das vacinas e o material para descarte.

Diante de tantos e complexos acontecimentos, este dia reverberou em reflexões. No recorte de um momento específico, existe a escola, o sistema biomédico atuando, diferentes atores sociais interagindo, há ações e reações ocorrendo. Tudo isso poderia se configurar em boas fontes de análises. Entretanto, gostaria de trabalhar adiante, com mais detalhes, três importantes insights que tive neste dia e que me instigaram a pensar de modo mais denso a vacina HPV - a lista das meninas feita pela escola (o sim e o não contidos nela), a relação entre escola e centro de saúde e o riso dos garotos (o qual engloba as reflexões sobre o foco da campanha do HPV ser sobre nas meninas).

\section{As listas ou controlando o rebanho}

As listas que por vezes mencionei acima se configuraram dados etnográficos importantes. Produzidas pela escola, a pedido do centro de saúde, ela possuía os dados das meninas que estavam na faixa etária da campanha do HPV e serviam a diferentes fins. Pontualmente pude conhecer as diferentes maneiras de utilização das listas por meio das entrevistas realizadas tanto na escola quanto no centro de saúde. 
A confecção das listagens tinham três objetivos: a) as listas eram modos de controle e vigilância sobre as meninas da escola incluídas na vacinação. Incluídas no sentido de possuírem a idade alvo da campanha, ou seja, de 9 a 13 anos; b) estes papéis também se constituíam material comprobatório acerca de quem se vacinou ou não. Era uma segurança, apoiada no controle de nomes e doses, que a escola necessitaria caso vinhesse a ser interpelada por alguma mãe ou pai e; c) para o centro de saúde, as listas eram fontes de dados primários sobre a quantidade e ordem das doses (primeira, segunda ou terceira), assim, importantes para o levantamento estatístico que seria produzido para ser enviado à secretaria de saúde, os quais dados estatísticos retornariam ao centro de saúde na forma de reconhecimento e valorização.

Configurando-se em controle e vigilância sobre as meninas, as listagem continham colunas para o nome da adolescente, data de nascimento, endereço, nome da mãe, a respectiva dose que tomou no dia da vacinação e as datas das doses subsequentes. Estes dados ajudaram a marcar bem uma diferenciação muito importante feita nas listas: a das meninas vacinadas e das meninas não vacinadas.

Fernanda, a coordenadora da escola, ao passar nas salas avisando sobre a vacinação, disse anotar ali mesmo os nomes e as idades das meninas que possivelmente receberiam a vacina HPV. Ela fazia essa anotação previamente, só depois disso, as meninas recebiam o comunicado sobre a vacina, para levarem para casa, com a finalidade das mães/responsáveis autorizarem ou não a vacinação. A princípio, na ótica da escola, todas as meninas listadas configuravam-se disponíveis para receber a vacina. Caso uma ou outra não pudesse ser vacinada, isto seria uma exceção, confirmada no termo de recusa ou por algum posicionamento por parte das mães ou pais. O que quero dizer é que todas as meninas estariam na lista, inclusive, as meninas não autorizadas, as quais chamo de "meninas do não".

Sobre estas meninas, Fernanda agia com maior vigilância. Ao receber o comunicado de que a menina não poderia ser vacinada, ela entrava em contato com os pais para confirmar tal informação e mostrava-se disponível para orientar a mãe, caso quisesse ter mais informações sobre a vacina. No dia da vacinação, percebi que Fernanda conhecia a fundo o motivo pelo qual uma única menina da lista não ter podido ser vacinada, "a mãe é crente [evangélica], não deixou, ficou com medo da filha transar mais cedo. Pura ignorância”. Essa menina, de acordo com a escola, tinha sua identificação reservada do restante dos alunos e dos professores, apenas Fernanda e Karen sabiam quem ela era. 
Estas listas eram tidas como um instrumento de poder e regulação. Segundo definição de Blackburn (1997), poder é "a capacidade de este conseguir algo, quer seja por direito, por controle ou por influência. O poder é a capacidade de se mobilizar forças econômicas, sociais ou políticas para obter certo resultado (...)" (BLACKBURN, 1997 apud FERREIRINHA, 2010, p. 368). As listas, instrumentos de poder, mobilizaram por si sós forças diferenciadas e de fontes distintas para se obter a adesão esperada à vacina.

Para Foucault (1987), a construção do sujeito dócil, útil e submisso à ordem estabelecida é possível apenas por meio de processos de controle social, e a disciplina é um deles. Ao sujeito pede-se conformação ao que é solicitado pelo meio social. E a escola é um ambiente propício para isto, como visto anteriormente.

Quanto ao item "b", das listas serem uma forma de resguardo para a escola, esta proteção se justificava pelas listagens se configurarem documentos institucionais produzidos no ambiente escolar e posteriormente, ratificados pelo centro de saúde. Era um meio burocrático e comprobatório de que a escola recebeu de fato a vacinação. Por conter os dados das meninas vacinadas e suas respectivas doses, eram itens solicitados para conferência de uma informação ou atestado de vacinação. Geralmente, as listas originais não ficaram na escola, eram entregues ao centro de saúde, porém uma cópia sempre ficara à mão, caso necessário.

Por último, as listagens figuravam-se fonte de dados valiosos para o centro de saúde responsável pela vacinação da escola do Gama. Segundo Raul, o posto as utilizava, assim como a escola, também como uma forma de controle da vacinação e de documento oficial, mas havia outra utilidade importante: a produção de estatísticas. As listas informavam a quantidade de vacinas e o tipo de dose aplicadas no dia da visita à escola, o que posteriormente, seriam os dados utilizados pela vigilância epidemiológica para a produção de porcentagens, gráficos e tabelas, as quais "concretizariam" e permitiriam visualizar o trabalho realizado pela Secretaria de Saúde na campanha do HPV. Bruno Latour (2000) trabalhou o poder das estatísticas enquanto tecnologias de governo, trazendo pessoas, objetos e situações àqueles a quem cabe tomar as decisões políticas, na forma de tabelas, gráficos e cartogramas. Afinal, os números são dados muito importantes para as ações em saúde, eles representam e materializam os resultados esperados, como apontou o secretário de saúde do GDF, em 2014: "Isto acontece com praticamente todas as vacinas, visto a intenção de contrapor o trabalho realizado e a meta estabelecida de antemão nas campanhas” (CORREIOWEB, 2016). 
A fidelidade das informações da lista era muito importante para uma boa e correta estatística. Tanto é que a escola fazia o preenchimento inicial da listagem, mas caso fosse necessário, no dia da vacinação, o centro de saúde poderia completar ou alterar algum dado, incluir uma jovem ou outra informação.

Estatística e saúde possuem uma parceira antiga. Conforme Senra (1999), de ferramenta para melhor gerir e administrar o Estado, a estatística ganhou um novo sentido que a transformou em fonte de informações que se encontram a serviço da ciência do registro, de conservação e de análise de dados, contribuindo assim para a elaboração de novos conhecimentos da vida social. A partir do momento em que se intensificou o movimento higienista, a contagem e os números passaram de vez a serem fundamentais para a saúde.

É nesta ótica das descrições estatísticas sociais, que se colocam as pesquisas médicas com a aspiração de construir um quadro sinóptico no qual as doenças dos habitantes de cada local seriam avaliadas. Assim, final do século XVIII, surgem as estatísticas sociais ligadas ao movimento higienista que tinha como função a redução da morbidade a partir da melhoria do curso da água e do ar. (...) A função dos estatísticos visava então realizar trabalhos sociais, identificar, para melhor gerir os incômodos presentes nas sociedades. Todos os estudos encontraram, na estatística, instrumentos que possibilitavam obter conhecimentos sobre a humanidade e, ao mesmo tempo, governar um território e um povo. (MARTIN, 2001, p. 27)

$\mathrm{Na}$ sociedade industrial capitalista, a estatística caracterizou-se, fundamentalmente, como meio de gerir e controlar a vida, o que trouxe à tona o conceito foucaultiano de biopoder, isto é,

o poder que se direciona não mais para o corpo individualizado, mas para o corpo coletivo. O biopoder não se diferencia somente do poder disciplinar, mas também do poder soberano, pois enquanto na soberania havia um direito do soberano "deixar viver" ou "fazer viver", no biopoder haverá uma tecnologia de poder voltada para o "fazer viver" e o "deixar morrer", que será um poder que vai se encarregar da preservação da vida, eliminando tudo aquilo que ameaça a preservação e o bem estar da população. (DINIZ; OLIVEIRA, 2014, p. 143)

A geração de dados, necessária ao biopoder, buscava subsídios que possibilitassem mensurações, comparações e aquisição de conhecimentos sobre novos métodos de 
operacionalização do sistema frente às necessidades de controle e expansão do Estado. Para além de quaisquer outras funções, os números estatísticos serviriam ao "olhar político dos Estados" (MARTIN, 2001, 26). Assim, as informações estatísticas ganharam dimensões sociopolítica e técnico-científica, que posteriormente viriam a ser objeto de polêmica, por servir a interesses diversos.

Chamadas de inscriptions por Gupta (2012), as estatísticas se configuram como práticas escritas da burocracia. São dados matemáticos que registram pessoas, materializam o valor e a importância do contar. Esses registros estatísticos têm uma finalidade precisa: delimitar o fenômeno em questão para melhor controlá-lo ou nele intervir de maneira eficiente. São notadamente destinadas a uma análise científica da sociedade, por isso caro à Ciência da Saúde. O Estado usa as estatísticas como um instrumento legitimador de sua ação na vida social. Dentro da ótica do fenômeno vacinal, as estatísticas podem ressignificar as políticas públicas de saúde, demonstrando o sucesso ou o fracasso de um empreendimento.

De papéis em campo a uma grandiosa fonte de análises sociais, as listas marcam por si sós uma das mais complexas ferramentas de atuação da vacinação do HPV. Para falar mais sobre elas, apresentarei os dados em dois campos distintos: os sim e os nãos dados à vacina contidos nas listas.

\section{O sim da lista}

A proposta desta sessão é falar sobre o sim, sobre a aceitação da vacina. Gostaria de relatar alguns motivos, argumentos e/ou situações que levaram algumas meninas a participar desta campanha vacinal. Considero que mães e pais fizeram parte deste processo de forma intensa, mas a eles dedico o capítulo seguinte, por demandar outros tipos de análises.

Anteriormente à escolha por se vacinar ou não, havia uma listagem a ser confeccionada pela escola. Fernanda, a coordenadora, como disse foi a responsável neste colégio pela confecção destas e já discutiu-se sua utilidade. Todas as meninas que possuíam a faixa etária desejável pela campanha, figuravam-se inscritas na lista, eram as possíveis "meninas do sim". Caso não pudessem ser vacinadas, a pedido das mães ou pais, o nome desta menina era mantido na lista, mas com a inscrição "não pode vacinar". 
De acordo com o que encontrei em campo, as "meninas do não" eram raras. A maioria das estudantes aceitou ser vacinada. Das meninas vacinadas que conversei e entrevistei, um padrão foi surgindo: as adolescentes desconheciam a associação entre HPV e câncer de colo uterino. E mais, pareciam não ter conhecimento prévio do vírus. Frente ao desconhecimento, o maior motivo apresentado por elas e que justificava a vacinação era a ideia de prevenção ${ }^{43}$, geralmente naturalizada pela premissa que "vacina é bom porque previne".

Apresentarei abaixo algumas entrevistas realizadas na escola com diferentes meninas, de diferentes turmas. Quase sempre estas conversas eram realizadas no pátio interno do colégio, em dupla ou grupo focal, com gravador e um roteiro de perguntas semiestruturado. Eu deixava que elas mesmas conduzissem a entrevista e ficassem à vontade se não quisessem comentar algum assunto. Vejamos como elas abordaram o tema da prevenção:

Entrevista em dupla. Presentes: Raquel, de 12 anos e Amanda, de 11 anos, ambas do $7^{\circ}$ ano:

Natália: Você sabe para o que é essa vacina que tomou?

Raquel: Não.

Amanda: Amiga, acho que é para proteger... Acho que da AIDS, sei lá, de alguma coisa. Não! É algum tipo de doença que pode ter no útero, não sei bem. Mas ela é boa para prevenir!

Natália: Vocês tiveram uma palestra, alguma instrução na escola, antes de vocês tomarem?

Amanda: Não. Só falaram que quem não tivesse tomado a vacina que fosse até a sala da Direção e tomasse. A gente só tomou e pronto. (DIÁRIO, 01 de dezembro de 2015).

Grupo focal. Presentes: Bianca, de 11 anos, e do $6^{\circ}$ ano, Paty, de 11 anos, também do $6^{\circ}$ ano, Maria, de 12 anos e Clarissa, de 12 anos, ambas do $7^{\circ}$ ano:

Paty: Até hoje eu não sei nem o que é isso aí. Não sei o que é HPV, só sei que é uma doença.

Clarissa: Eu não sei muito sobre essas coisas, minha mãe fica falando um monte de coisa, mas eu não presto muita atenção.

Bianca: Até hoje eu não sei para o que serve essa vacina, mas se existe, é para alguma coisa importante!

Natália: Entendi. Mas como importante? O que vocês acham?

\footnotetext{
43 O termo 'prevenir' tem o significado de "preparar; chegar antes de; dispor de maneira que evite (dano, mal);
} impedir que se realize", muito utilizado pelos profissionais de saúde, popularizou-se. (Ferreira, 1986) 
Bianca: É para prevenir uma doença.

Clarissa: Sim, é uma doença que a gente tem que se prevenir, não pode ficar esperando até que ela acontecer dentro de você. (DIÁRIO, 30 de abril de 2016)

Embora poucas soubessem para quê ou o porquê estavam se vacinando, a maioria possuía o discurso a priori de que se a vacina existia era importante. Esta retórica de prevenção não é própria da vacina do HPV, é antiga, pertence ao mundo sociocultural, sendo construída frente aos perigos e riscos que o ser humano encontrou no decorrer da sua história e do seu convívio social (CAMPOS, 2002) frente às doenças. Nas respostas dadas pelas meninas, os elementos prevenção e proteção apresentaram-se novamente com força e significado para as entrevistadas, evidenciando uma adequação ao discurso construído historicamente quanto a utilidade das vacinas, mas que revela o estabelecimento de um hábito, de uma tradição, que vem sendo repassado de geração em geração nas últimas décadas - a cultura da imunização. Este termo prevenção, base do discurso sanitário brasileiro, representa, nas categorias nativas, uma "evitação" de um mal, de uma doença.

No decorrer desta história, as práticas preventivas fortaleceram-se, no que diz respeito a riscos e agravos à saúde, nos diversos espaços da vida social, com a incorporação de produtos e tecnologias de consumo individual no ambiente doméstico, no trabalho, na escola, nas atividades de lazer, podendo ser, cada vez mais, privilégios de poucos, ampliando a desigualdade entre grupos sociais, em termos de condição, estilo e modo de viver. (CAMPOS, 2002, p. 63)

Vacinas, para algumas pessoas, podem ser compreendidas como práticas preventivas que conferem privilégios. Este tipo de abordagem pôde ser visto em certas falas em campo, como nas falas de Fernanda, ao dizer "Vocês são moles demais, eu já tomei essa vacina e não doeu. Isso é para proteger vocês. Vocês têm sorte! Vamos lá!”. Se a palavra prevenção era uma retórica para as meninas, esta também se mostrou marcante no discurso dos profissionais da educação e da saúde. Raul, o técnico de enfermagem que visitou a escola do Gama, quando questionado sobre o porquê da vacina, à menina que lhe indagou ele disse: "É bom, é para você ficar uma moça protegida". O privilégio de se ter uma vacina ali disponível era sempre lembrado. O termo prevenção foi um termo importante e sustentou a vacinação em campo, pois todas as ações foram feitas em prol de certa "prevenção". 
Grupo focal. Presentes: Larissa, de 10 anos, Ingrid, de 11 anos e Anna, também de 11 anos. Todas são do $6^{\circ}$ ano:

Natália: Mas vocês sabem para o que é essa vacina?

Larissa: Eu sei! Para o câncer de mama... [e me dá uma olhada esperando uma confirmação]

Ingrid: Eu não me lembro muito bem.

Natália: Você está certa, é para o câncer mesmo, mas de útero. E vocês descobriram por meio de que? Propaganda?

Larissa: Eu, por cartaz! O cartaz estava, bem assim, do lado da escola, aí minhas amigas e eu fomos lá e lemos.

Anna: Deu na televisão, minha mãe também me falou. É para a prevenção, né! Eu, por exemplo, toda vez que eu tomo uma vacina eu anoto no meu celular o dia que foi. Acho importante.

Larissa: Eu também faço isso! Mas eu anoto em um calendariozinho.

Ingrid: Eu também, sempre quando é um dia especial, eu faço um circulozinho, mas quando eu tomo uma vacina importante, eu faço um círculo e ainda anoto em cima da data, "vacina". (DIÁRIO, 30 de março de 2016)

\section{Foto 5}

Percepções.

Dezembro, 2015.

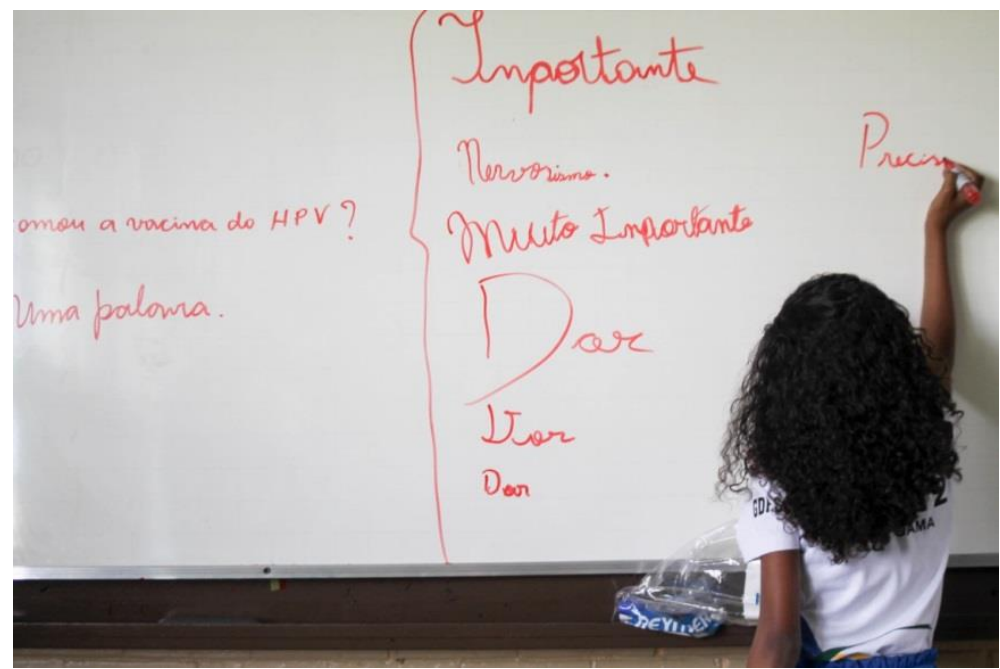

Creio que a adesão à vacina não dependia apenas da prevenção que ela trazia em si, mas de outros fatores, que somados a este, fizeram com que a vacina HPV alcançasse altos números de "sim" nos primeiros anos. Foram muitos os artifícios que tornaram maior e mais intenso o apelo para se tomar a vacina, afinal, estes artifícios vinham especialmente nos incentivos por parte dos professores, da Direção, dos colegas. Várias foram as estratégias de 
convencimento para que o sim na lista fosse de fato numeroso ou frequente e automático, falarei a frente. A adesão era desejada porque ela não causava tantos desgastes quanto um não.

\section{Quem tem medo de Gardasil ${ }^{44}$ ?}

Durante o dia da vacinação, dentre as quarenta e seis garotas vacinadas, apenas três não receberam a vacina: uma tinha faltado à escola no dia, a outra foi transferida de regional e a terceira, não pode ser vacinada porque a mãe não permitiu. O caso da negativa rendeu uma série de reflexões.

Contei ainda agora este caso da "menina do não", o qual a coordenadora Fernanda sabia em detalhes os motivos que não permitiram que ela fosse vacinada. Em uma entrevista ela me explicou com mais calma sobre essa rejeição à vacina:

Aparentemente, algumas mães que não queriam que as filhas tomassem a vacina. Eu acho que devido a preceitos religiosos, questão comportamental, enfim, eu não sei. A gente não entrou muito no mérito. Eu acho que foi por causa do sexo, medo da filha iniciar a vida sexual por se sentir protegida. (DIÁRIO, 25 de agosto de 2016).

A coordenadora disse tentar manter a identidade dessas garotas em sigilo, mas os nomes delas sempre acabavam conhecidos, visto as mesmas comentarem com algumas colegas em sala o fato de não terem tomado a vacina, e esta, por não guardar segredo, espalhavam a notícia. Isto, segundo Fernanda, "gerava fofoca e brincadeira, na tentativa de saber o porquê aquela mãe não tinha deixado a filha ser vacinada". Ela ainda considerava uma espécie de "vergonha pública" o que a menina passava, caso a história fosse descoberta.

Se por medo da vacina, por motivos religiosos ou por quaisquer outras convicções, Fernanda contou-me que sempre que produziu as listagens das meninas da escola havia uma negativa. O que me intrigou em campo foi o fato de eu sempre buscar por estas "meninas do não" e não encontrá-las. Em entrevista, Fernanda me apresentou um dado numérico de 3\%

\footnotetext{
44 Este subtítulo é a tradução do título do trabalho de Karen Houppert, este denominado: “Who’s Afraid of Gardasil?”, citado em artigos de Wailoo et al (2010, p. 135).
} 
para as meninas não vacinadas de cada turno da escola, ou seja, manhã e tarde. Ela me explicou melhor a baixo:

Fernanda: Olha, eu acho que, em média, foram umas três meninas por turma que não puderam ser vacinadas, são dezessete turmas, aí você coloca uns 3\% por turno.

Natália: Engraçado isso, porque eu fui mapear essas meninas nas salas e eu não consegui achar. Será que elas não quiseram conversar?

Fernanda: Por isso que eu estou te falando... De 35 alunos... Provavelmente elas não quiseram conversar. (DIÁRIO, 25 de agosto de 2016)

Esta porcentagem representava cerca de 15 meninas, era um número expressivo para mim, mas eu não as localizava. Karen, a supervisora pedagógica, teria uma hipótese. Certa tarde, em uma conversa informal na sala do SOE com Inês, Karen e Silvia, eu aproveitei para desabafar com elas sobre este meu "problema" em campo. Karen ao me ouvir foi logo me alertando: "Natália, as meninas estão se escondendo de você. Acho que pensam que você é do Conselho Tutelar ${ }^{45 ", ~(D I A ́ R I O, ~} 30$ de junho de 2016).

Ela me disse que ali na escola conhecia casos de mães e pais que mentiam ao dizer que a filha foi vacinada, pois eles tinham medo, segundo ela, de serem "pegos" pelo Conselho Tutelar, que poderia querer alguma satisfação sobre a vacina, "afinal, o conselho tutelar pode denunciá-los". Aqui eu via a vacina na cabeça desses pais como algo obrigatório e vigiado pelo Estado, pois como discutido, a vacinação figura-se em lei, o que traz um peso sobre ela. Parece então que o conselho tutelar era motivo de medo para essas pessoas. Karen ainda tentou me ajudar de outras maneiras, me entregando uma listagem que, segundo ela, era só de meninas que não puderam ser vacinadas. Como a listagem possuía o número de telefone, eu liguei para as meninas, mas quase todas elas estavam com as doses da vacina HPV em dia, para uma ou outra garota, faltava apenas uma dose. Por desatenção minha ou inexperiência, apenas mais tarde eu pude compreender que estes "nãos" que recebi em campo poderiam querer dizer alguma coisa.

Queriam me alertar que talvez eu não devesse insistir em achar essas meninas, afinal, o “não" era um dado etnográfico em si. Mas, especialmente frente à dica que recebi de Karen,

\footnotetext{
45 O Conselho Tutelar é um órgão criado pelo Estatuto da Criança e do Adolescente, visando à desjudicialização das medidas sociais dirigidas à infância. Ele representa uma estrutura social com poderes para agir contra o próprio Estado e/ou a família, sempre que um direito ou necessidade básica de uma criança ou adolescente esteja sendo violado ou sob ameaça de sê- lo. (Vogel, 1995)
} 
percebi que as meninas tinham resistência em falar de suas não vacinações, pois era algo que parecia trazer insegurança. Fato é que tive contato com uma adolescente de 13 anos em campo, como sugestão de algumas amigas dela, que me falaram que esta não havia tomado a vacina HPV. Esta garota era Ana Luíza, do sétimo ano. Ela era branca, dos cabelos cacheados (sempre presos num coque), muito tímida, a ponto de não me olhar nos olhos enquanto conversávamos. Ana Luíza morava com os pais em um barraco na área rural do Gama e tinha três irmãos. Ela foi uma das mais interessantes interlocutoras em campo, pois revelou ideias inesperadas e tocou pontos antes não ouvidos por mim. Abaixo, destaco trechos da entrevista, realizada embaixo de uma árvore, no pátio externo:

Natália: Você tomou a vacina? Quantas doses?

Ana Luíza: Eu só tomei uma dose, na escola. Foi aqui e foi ano passado.

Natália: Você não teve que levar uma autorização para casa, trazer o cartão de vacina?

Ana Luíza: Não. Foi tudo na hora.

Natália: quem decidiu que você tinha que tomar?

Ana Luíza: Eles! Por que eu não queria tomar!

Natália: Eles quem?

Ana Luíza: Foi uma mulher, acho que do Hospital. Eu estava dentro da sala. Aí o que foi que aconteceu? Eles me chamaram em sala, até aí tudo bem, eu fui. Mas quando cheguei lá, tinham muitas meninas. Algumas foram forçadas a tomar. É isso. Eu não queria tomar, mas eu fui obrigada.

Natália: Entendi. Mas me conta, por que você não queria tomar?

Ana Luíza: Eu acho que o que tiver que ser, será! Se eu tiver alguma doença, eu vou ter essa doença se tiver no plano de Deus, eu vou ter! Não adianta vacina, então eu não queria tomar!

Natália: Seguraram você no dia para tomar?

Ana Luíza: Seguraram não, se eu falasse que me seguraram, eu estaria mentido. Eu falo que não foi uma escolha minha, mas não me seguraram. Já faz muito tempo que eu ouvi falar dessa vacina, não eu não queria.

Natália: Isso tem a ver com religião?

Ana Luíza: Bem, com religião não, quer dizer, na minha família ninguém tem religião, cada um acredita no que quiser. Eu não gosto de contar muito isso, porque tem aquele lance do conselho tutelar. (DIÁRIO, 4 de julho de 2016)

Ana Luíza era um “não” à vacina. Ela não queria ser vacinada, mas acabou tomando a primeira dose. Não ficou claro em sua fala se foi por influência ou obrigação, mas o fato é que não voltou mais para tomar as doses restantes. Afirmou que sempre que Fernanda passava nas salas, ela dizia que já tinha tomados todas as vacinas e, por ter 13 anos, este fato a ajudava, pois 
esta era a idade limite da vacinação, logo, esperava-se que com essa idade uma garota já estivesse com todas as doses aplicadas. Quer dizer, de modo muito interessante para essa pesquisa, o "não" de Ana Luíza não significava e nem equivalia necessariamente ao fato de ela não ter tomado a vacina, mas que isso havia acontecido à sua revelia. Sua negativa localizava-se no plano da opinião e da reflexão, ainda que essa negativa não tivesse sido respeitada na prática médica - e talvez o fato de ser jovem e depender do aval pa/materno, esse desrespeito por sua opinião pessoal fosse ainda mais naturalizado pelas autoridades escolares e sanitárias. E, mesmo tendo recebido uma primeira dose, sua opinião e rechaço da vacina se mantiveram, reforçando e deixando ainda mais claro o seu não querer e, na prática, confirmando e deixando ainda mais forte a sua decisão de não retornar para a segunda e terceira doses.

Ana Luíza contou-me também que tinha me visto várias vezes pela escola, mas pensava que eu era da saúde, que estava atrás das meninas para vacinar ou mesmo que eu estava "investigando", a fim de descobrir quem ainda não se vacinara. Foi sua amiga, a Beatriz, da sua turma, que contou para ela que eu fazia uma pesquisa para a faculdade, que já havia conversado comigo. Por isso ela, Ana Luíza, concordou em conversar.

Para minha maior surpresa, Ana ainda tocou no assunto sobre o conselho tutelar. Eu aproveitei para perguntar mais. Ela o descreveu como uma espécie de vigia das crianças e adolescentes. Para ela, este punia as crianças mal-educadas e com pendências escolares (será que com pendências de saúde também?). Foi assim que esta garota fez com que eu entendesse os possíveis nãos que estava recebendo em campo. A história da supervisora pedagógica Karen encontrava-se com a história de Ana, que por sua vez, encontrava-se com as minhas desconfianças quanto às garotas se esconderem de mim.

Resta-me perguntar - quem tem medo de Gardasil? Para a "menina do não" que contatei, Ana Luíza, o medo da vacina quanto seus efeitos ou reações não era um problema, mas sim, o medo da coação que poderiam sofrer, caso se diferenciassem da maioria que tomou todas as doses da vacina. A escola, enquanto instituição disciplinar, "produtora de listagens", também agiu constrangendo muitas meninas, tanto na figura da instituição quanto na das colegas.

De todo modo, a escola estava trabalhando no que a ela foi solicitado pela Secretaria de Saúde, que divulgasse as informações da vacina HPV e ajudasse na participação das meninas neste processo. Uma forma encontrada foi por meio do trabalho midiático, de propaganda, 
realizado especialmente com o uso dos cartazes da campanha do Ministério da Saúde. O outro foi o trabalho pedagógico dispensado pela escola frente às meninas.

\section{Escola e centro de saúde: parcerias e controvérsias}

Segundo Colgrover (2010), a vacina foi para dentro das escolas como uma oportunidade de se acessar mais rápido o público adolescente, alvo da política de vacinação. Esta mudança de ambiente é perspicaz, pois o público adolescente é o que menos visita as unidades médicas, logo, a entrada na escola é uma intervenção eficaz de acesso a ele. A escola, como disseminadora de conhecimento, teve papel relevante ao influenciar as meninas a favor da vacinação.

Às escolas foi solicitado que procedesse à divulgação prévia da campanha do HPV antes da visita do centro de saúde designado para a vacinação. Cada instituição de ensino ficou "livre" para proceder como desejasse, comentei sobre isso. Na escola do Gama, os avisos em sala e os cartazes foram os meios escolhidos. Fernanda me descreveu assim as solicitações da Secretaria de Saúde:

Falo que o HPV foi uma imposição. Eu fui a uma reunião e eles falaram assim: "os postos de saúde vão entrar na escola para fazer a vacinação das meninas entre 9 e 13 anos. Quero a relação de todas as meninas. Dia 'tal' eu preciso de tantas meninas para vacinar, todas nessa faixa etária". Eu falei assim: "Tá bem, mas todo mundo vai tomar vacina?", eles responderam: "Vai. Tá aqui o termo de recusa se o pai não deixar". Só falaram isso. Eu particularmente achei incoerente porque era para [as pessoas da secretaria de saúde] terem conversados com as meninas antes. Foi o trabalho que eu fiz. Tanto que no dia da vacinação elas estavam em massa e eu nem precisei brigar muito pra elas tomarem a vacina, entendeu? Depois que eu expliquei em sala sobre as causas e as consequências [do HPV], não teve meninas que quisessem fugir. (DIÁRIO, 25 de agosto de 2016) 


\section{Foto 6}

Mural de entrada da escola. Lugares de destaque e de grande circulação de pessoas eram locais de lembrar a vacina $H P V$.

Dezembro, 2015.

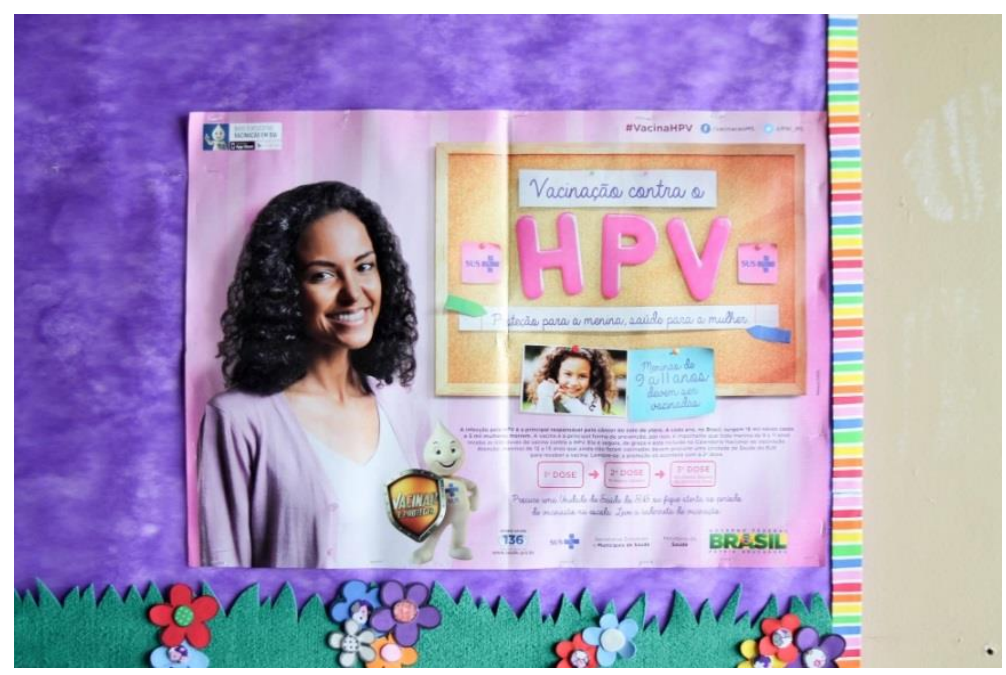

Coerente com as demandas da Secretaria de Saúde, a escola começou então a planejar sua atuação para a vacina acontecer. Começaram pelos cartazes. Na escola do Gama, eu vi vários deles espalhados pelas paredes, perto dos bebedouros, ao lado das salas de aula, estes já velhos pela ação do tempo, mas que não deixavam de cumprir sua missão - informar e relembrar sobre a vacinação. Cabe destacar que estes cartazes (com suas cores, letras e desenhos) eram sempre alusivos ao concebido universo adolescente feminino. Geralmente usava-se o cor-de-rosa como fundo, as letras eram grandes e coloridas, os desenhos eram sempre de agendas, celulares, batons, sapatos. Havia também, em boa parte deles, a da figura de uma mãe, acompanhada de sua filha.

Conforme Wailoo et al (2010), mulheres e meninas são representadas nessas propagandas como itens de pureza e inocência, pulando corda, brincando juntas, onde se predomina uma relação pacificada. Os slogans da campanha eram sempre "Proteção para a menina, saúde para a mulher"; "A vacina HPV é direcionada apenas para as meninas"; "Meninas de 9 a 13 anos devem ser vacinadas" (BRASIL, 2016). A prevalência dessas expressões enfatizava uma lógica vacinal e preventiva voltadas para o sexo feminino. E mais, havia no cartaz um pequeno lembrete, na lateral direita superior, que incentivava a procura por informações ou o controle das vacinas por meio do uso da internet ou de aplicativos. Isto se 
dava especialmente por meio das propagandas do Ministério da Saúde, o qual disponibilizou o aplicativo Vacinação em dia ${ }^{46}$, para usuários de smartphones e tablets.

Assim percebe-se que, ao invés de coerção legal ${ }^{47}$, a vacina foi proposta por outros meios persuasivos: publicidade nas mídias de massa, folhetos, cartazes, e também por meio da educação que o ambiente escolar podia oferecer. Até mesmo pirulitos e doces também foram uma forma de atingir o público vacinal, como explica Silvia, uma das orientadoras da escola do Gama:

Silvia: Então, no dia da vacinação, o que eu fiz? Eu comprei um saco de pirulito. Eu pegava o cartão de vacinas, ia de turma em turma, chamava as meninas, levava para a sala da vacina, dava um apoio moral. Se vacinasse, ganhava um pirulito. Se saísse chorando, ganhava também, eu consolava, "Chupe um pirulito" e dava um abraço.

Natália: E o pirulito tinha o intuito de ser comemorativo, de ser uma recompensa?

Silvia: Não, o pirulito era um acolhimento, assim, um conforto. "Doeu? Mas chupa um pirulito para amenizar".

Natália: Você acha que alguém tomou a vacina só para ganhar o pirulito?

Silvia: Não, acho que não, muitas não quiseram tomar. (DIÁRIO, $1^{\circ}$ de junho de 2016)

Silvia era goiana, tinha 52 anos, era casada, mãe de dois filhos, muito simpática, e há dezenove anos trabalhava na Secretaria de Educação. Ela se referia à primeira vacinação da escola do Gama, em 2013. Para ela, sua "gentileza” estava ao lado do "trabalho pedagógico" da escola. Quanto à escola, esperou-se que ela utilizasse seu trabalho pedagógico para atingir as meninas quanto à importância da vacina e, assim, obter a adesão almejada.

46 Este aplicativo é capaz de gerenciar cadernetas de vacinação cadastradas pelo usuário, além de abrigar informações completas sobre as vacinas disponibilizadas pelo SUS e uma função com lembretes sobre as campanhas sazonais de vacinação. Ele possibilita: a) que você crie e acompanhe cadernetas de vacinação, marcando a data da imunização e agendando a próxima; b) receber lembretes sobre as campanhas sazonais de vacinação promovidas pelo Ministério da Saúde; c) encontrar um detalhamento de todas as vacinas disponibilizadas pelo SUS; d) calcular, a partir da inserção da primeira vacina no calendário, quando o usuário deve comparecer ao posto de vacinação para uma nova imunização e envia um lembrete por mensagem; e) imprimir os calendários de vacinação cadastrados no aplicativo Vacinação em Dia podem ser enviados via e-mail para impressão. O objetivo é estar presente no dia a dia da população, oferecendo, em um dispositivo móvel, todas as informações necessárias para garantir a imunização do cidadão e de sua família. (BRASIL, 2016)

${ }^{47}$ Um exemplo de coerção legal seria a exigência da vacina para matrícula escolar. Embora exista uma lei (Lei n. 3146/2012) que pede que as escolas orientem as famílias cujos cartões dos filhos estejam desatualizados, esta proposta não condiciona a matrícula dos alunos à apresentação da documentação exigida e, portanto, não fere o direito à educação obrigatória, garantido pela Constituição Federal. (BRASIL, 2013) 
Para além dos avisos em sala, mencionados por Fernanda, e dos cartazes enviados pela Secretaria de Saúde e doces, algumas escolas usaram estratégias adicionais. Em uma conversa com Inês, outra orientadora educacional da escola, que até o ano anterior trabalhava em uma escola classe $^{48}$ do Gama, esta me relatou que em sua antiga escola o tema do HPV foi muito bem trabalhado, afinal, houve um teor de imposição da vacina, assim como contou Fernanda no caso da escola do Gama.

[A vacina] foi assim uma ordem! Não foi assim "Vocês querem?", foi "Olha, essa escola aqui terá a vacinação, vai ser o nosso posto, então a gente já vai querer o nome dos alunos", e a gente da escola organizaria tudo, as listas, as palestras com os pais, as palestras com os alunos. Parece que teve uma "lei" que mandou que a escola fizesse esse tipo de acolhimento, porque primeiro tem que ter uma palestra com as meninas, uma preparação com a família, para depois elas receberem essa vacina. Eles acharam que a escola seria o melhor lugar para fazer isso, do que no posto de saúde. Eu penso que deve ser feito todo um trabalho pedagógico, para eles entenderem, tanto os alunos quanto as famílias entenderem o porquê da vacina, né? Então eu vejo que a escola é o melhor lugar para fazer esse tipo de atendimento, de divulgação, de preparação. (...) (DIÁRIO, 12 de dezembro de 2015)

$\mathrm{Na}$ escola anterior de Inês, houve maior divulgação das informações do HPV, com palestras, reunião com as famílias, bilhete para casa, ao contrário da situação encontrada na escola do Gama, que optou apenas pelos avisos e cartazes. Seria devido à faixa etária de uma escola classe? Com um público ainda infantil (até 11/12 anos) segundo Inês, era necessário um cuidado extremo ao falar sobre a vacina, tanto que ela sempre pensava nas palavras certas ao tocar temas que a vacina chamava à questão, como sexualidade. Ela contou que sempre procurava se remeter ao vírus em conexão com o corpo da criança, seu desenvolvimento sexual físico e não sobre uma sexualidade partilhada, sobre relações sexuais.

Natália: Pois é, eu ia te perguntar isso, como foi a abordagem sobre sexo? Você falou sobre isso? Teve dificuldade?

Inês: Não, não tive. Primeiro, separei só as meninas. Aí eu falei para elas: “Tem coisas que vocês devem saber e a gente, por preconceito, por medo, não toca no assunto". Então eu comecei a falar sobre isso, aos pouquinhos... Mostrei o útero "Olha, isso a gente tem, tá aqui”. Aí mandei todo mundo botar a mão [abaixo do umbigo, ela gesticulava]. "Está vendo, tá aí dentro, a gente não vê, mas existe, tem que cuidar dele.

\footnotetext{
${ }^{48}$ Estas escolas atendem alunos do $1^{\circ}$ ao $5^{\circ}$ ano, do ensino fundamental.
} 
Essa vacina vai protegê-lo de algum vírus que possa vir mais tarde, quando vocês se tornarem bem adultas". Mas veja, não especifiquei bem sobre o ato sexual, foi bem por cima. Eu falei mais sobre as partes do corpo e sobre o vírus. (DIÁRIO, 07 de dezembro de 2015)

Fernanda, na escola do Gama, também tentou se manter firme quanto a falar apenas do vírus HPV, evitava assuntos mais delicados, como sexualidade, mesmo que as séries e idades fossem diferentes do público que Inês acompanhou na escola classe. Entretanto, isto não assegurava brincadeiras por parte dos alunos e alunas.

\section{Grupo focal. Presentes: Larissa, de 10 anos, Ingrid, de 11 anos e Anna, de 11 anos. Todas do $6^{\circ}$ ano:}

Natália: Para quem tomou a vacina na escola, vocês tiveram alguma orientação sobre a vacina? Por exemplo, a professora de biologia falou alguma coisa, ou a orientadora foi nas salas de aula contar sobre a vacina?

Larissa: Não! Elas só deram um bilhete para gente, dizendo assim "suas mães devem assinar e vocês devem trazer, junto com o cartão". Não falaram nada da vacina.

Anna: Na minha [escola] não mandaram "bilhete" nem nada, só chamaram a gente para dar a vacina [Giovanna estudou em outra escola ali perto]. (DIÁRIO, 30 de março de 2016)

Os professores, em geral, sabem que conversar sobre sexo era uma tarefa difícil e que demandava habilidades e sabedoria para lidar com as situações ou perguntas que as alunas/os poderiam fazer. Segundo Diniz (2014), em sua pesquisa, os professores que mais orientavam sobre as questões da educação sexual eram os professores de ciências e o tema não era muito bem tratado como tema transversal ${ }^{49}$. Como palpite, arrisco dizer que devido à escola do Gama ter tantos problemas de outras ordens, tidos como mais "sérios", como a violência, a pobreza, a repetência escolar, assuntos como saúde e vacina fiquem relegados ao segundo plano. Além disso, os jovens dali já se mostravam por demais adeptos à “zoação" entre alunos e professores, então quem se arriscaria a entrar em um assunto "espinhoso" como a sexualidade com aquele grupo?

A fala da orientadora Inês era muito significativa para pensar os motivos de a vacina ter sido levada para dentro da escola. Independentemente do colégio em questão, havia uma

\footnotetext{
${ }^{49}$ Que perpassa várias áreas de conhecimento ou disciplinas na escola.
} 
valoração do trabalho pedagógico desenvolvido, o qual parecia ser útil ao sistema de saúde, pois segundo Raul, técnico de enfermagem, a escola "preparava as pessoas para o que se queria desenvolver" (DIÁRIO, 03 de junho de 2015). Para além de saber falar de vacina (vírus, doses, eficácia), há que se saber como falar disto. São esses tipos de ações que resgatam ou acrescentam à discussão o caráter curativo e terapêutico da Pedagogia.

Segundo Milstein (2003), o trabalho pedagógico da escola se forma por meio da ideia de habitus, conforme Bourdieu (1971). Ele explica que pela transmissão dos saberes, se inculcam nos indivíduos certas predisposições quanto à percepção, ao sentir, pensar e viver a realidade, os quais se inscrevem nos corpos dos sujeitos, de forma um tanto duradoura (MILSTEIN, 2003), e marca "a escola primária, como lugar de passagem obrigatória de todas as crianças, é um espaço privilegiado de socialização imposto pelo Estado, espaço este que emergiu enfrentando outras formas de socialização e transmissão cultural ${ }^{50 \prime}$ (2003, p. 22, tradução nossa). Inculcar hábitos seria assim uma das tarefas da escola, segundo os autores, e o trabalho pedagógico sua materialização.

Essa valorização do trabalho pedagógico ainda se mostraria mais forte quando Inês relatou uma palestra ocorrida em sua antiga escola. Com o intuito de informar e esclarecer as alunas sobre o HPV, a escola classe teve a ideia de convidar uma médica ginecologista para ministrar uma palestra. Inês acreditava que seria muito proveitoso ter uma médica falando de HPV, para crianças/adolescentes de 09 a 13 anos. Entretanto não foi o que ocorreu:

Quando vem uma doutora para a escola, falar sobre determinada coisa, a gente aborda antes, "Olha doutora, quando vier tal pergunta a senhora corta e não responde". Eu não fiz isso porque eu era um pouco ingênua, eu achava que como ela se propôs a fazer essa palestra, pensei que ela já tinha esse pensamento, de cortar, de pular, de pedir para procurar depois, e não responder na bucha porque achava que era natural. Para um médico, ele que tá lá dentro [do sistema de saúde], é tudo natural. (DIÁRIO, 12 de dezembro de 2015)

\footnotetext{
50 La escuela primaria, como lugar de passo obligatorio de todos los niños, es um espacio privilegiado de socialización impuesto como obligatorio por el Estado que emergió enfrentándose a otras formas de socialización y de transmisión cultural.
} 


\section{Foto 7}

Entre olhos e ouvidos atentos, a explicação sobre o HPV.

Dezembro, 2015.

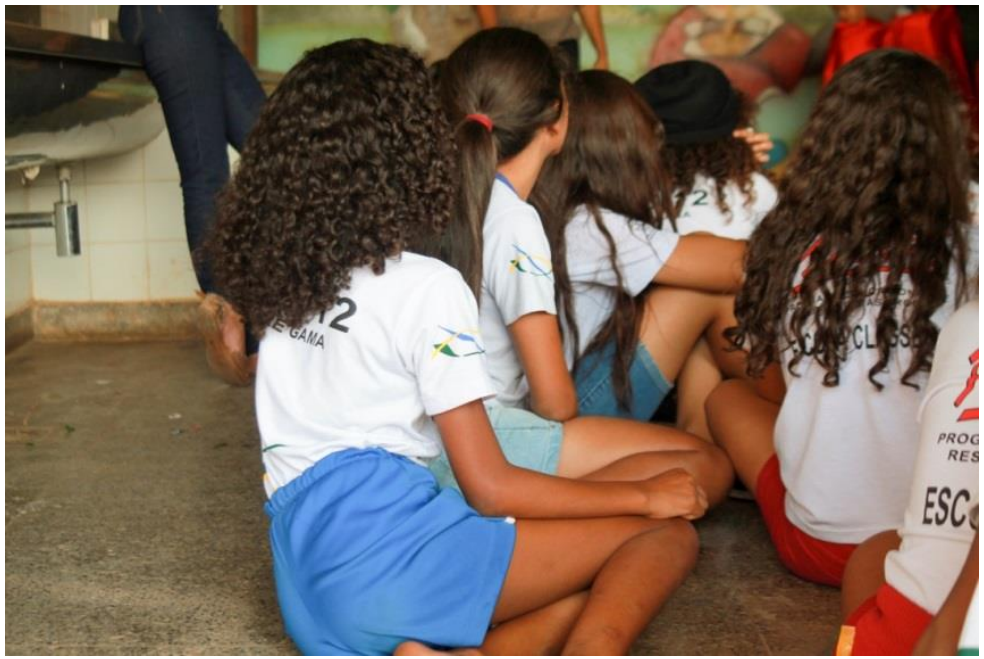

Inês acabou surpreendida com a falta de "tato" por parte da médica ao falar do tema que mais polemiza o HPV, que é a vida sexual - o contágio por meio do sexo. O fato narrado por Inês foi embaraçoso porque a doutora, devido à provocação de algumas alunas com mais idade, aprofundou o tema sobre sexo anal o que acabou por levar às meninas mais novas fatos antes não conhecidos. Talvez Inês não tivesse se atentado para a possibilidade de a vacina ter ido para as escolas justamente para ser explicada pelos profissionais pedagogos, tidos pelo senso comum como os mais experientes no repasse das informações aos alunos e alunas. Ou mesmo, que a vacina tivesse ido para as escolas para poupar o trabalho da transmissão da informação aos profissionais da saúde. $\mathrm{O}$ fato é que a palestra repercutiu em várias instâncias escolares, inclusive no meio das mães. Tive a oportunidade de conversar com uma mãe, que também é professora da mesma escola em que Inês trabalhou. Para tal mãe, a palestra reverberou de forma negativa:

Natália: Lu, como foi o processo da vacinação para a Beatriz. Inês me contou sobre o fato de uma palestra...

Luana: É. Foi uma coisa muito séria! Uma profissional do sistema de saúde veio aqui na escola fazer uma palestra sobre sexualidade. E... Não sei se ela teve orientação de quantos anos tinham as crianças que iam ouvir a palestra, mas eu sei que ela falou coisas... assim... que na minha opinião são um pouco absurdas. Tipo, o que era sexo oral, se podia ou não fazer, o uso da camisinha e tudo mais, como se as crianças tivessem vida sexual ativa. (...) A minha filha ficou muito sem graça, chateada, com medo, e eu percebi. E perguntei: “O que aconteceu na escola?". E ela "Eu não quero 
falar para você porque eu tô com vergonha”. Eu acho que não era o momento de falar daquela maneira. Foi muito bruto o que a médica fez. (DIÁRIO, 30 de março de 2016)

Embora a escola seja tida como local de conhecimento, as questões sobre o ensino da sexualidade ou sistema reprodutor, preconizados nos Parâmetros Curriculares Nacionais do Brasil $^{51}$ - PCN, parecem ainda resistentes a professores e pais e mães. Discutir-se-á mais sobre isso no capítulo seguinte.

Mesmo com a escola empenhada em disseminar as informações da vacina entre as mães e pais e alunas e alunos, Raul, técnico de enfermagem, contou-me em uma entrevista junto a Tereza, que eles tiveram que conversar com muitos pais sobre a vacina, apontando que talvez o saber médico se sobrepusesse ao escolar ou que a escola não teria alçando êxito no repasse das informações:

Natália: Então, em nenhum momento vocês fizeram parte dessas informações com os alunos?

Raul: Não, quem cuidou disso foi a escola, a escola ficou com toda essa parte da informação, mas tinham alguns pais que se sentiam inseguros e no dia da vacinação, eles vinham ver o que estava acontecendo e conversavam direto com a gente.

Tereza: Alguns deles não se deram por contente com as explicações da escola, e vieram falar diretamente com a gente: "Essa vacina é pra quê, é pra quê mesmo?". Depois que a gente conversava direitinho, as filhas vacinavam.

Natália: Entendi, vocês passavam confiança...

Raul: Confiança profissional. No dia da vacinação, a gente ia direitinho, ia de roupa branca, crachazinho do posto, tudo certinho e eles perguntavam mesmo. (...) E outra coisa também bacana que você falou: isso gerava confiança. Há a confiança no servidor na sala de vacina, porque nós vacinamos a mãe, depois vacinamos o filho, vacinamos o avô, vacinamos a avó, vacinamos todo mundo. Exatamente isso, você pega o bebezinho e depois pega o adolescente e depois de um tempo essa adolescente engravida, daí vamos vacinar a mãezinha nova, e aí vai na sequência. É um negócio interessante, eles [os pais, as pessoas] conhecem a gente por causa disso. Eles falam: “Ah! É aquele rapaz lá do posto. Pode fazer a vacina, é o rapaz lá do posto". (DIARIO, 03 de junho de 2016)

\footnotetext{
51 Os Parâmetros Curriculares Nacionais (PCN) são documentos produzidos pela Secretaria de Educação de Ensino Fundamental e Ensino Médio do Ministério da Educação publicados em 1997. O texto desses documentos é apresentado como um referencial de qualidade para a educação no Brasil. (CAMPOS, 2014, p. 126)
} 
Raul confirmou nessa fala, a preocupação inicial que teve no dia da vacinação na escola do Gama, quanto à falta de informação sobre a vacina que as meninas lhe demonstraram. Tereza ainda frisou "Alguns deles não se deram por contente com as explicações da escola", o que deixava nítido uma possível crítica quanto ao trabalho pedagógico desenvolvido. Entretanto, Raul não via o trabalho da escola de todo ruim, considerou este complementar ao da saúde, justificando até mesmo o sucesso da vacina no primeiro ano de campanha ao trabalho de divulgação realizado dentro das escolas.

Natália: Pra saúde essa aproximação com a escola foi bem vinda?

Raul: Sim, foi uma parceria que deu certíssimo.

Natália: Alguma coisa saiu errado? Chateou vocês?

Raul: Não, de jeito nenhum, muito pelo contrário, a gente chegava lá e erámos muito bem recebidos. Eles falavam: "Tantas crianças vão ser vacinadas. Da sala A vão ser tantas, da sala B vão ser tantas, da sala C vão ser tantas”. Em pouquíssimas escolas isto não estava bem feito. Eles ajudavam a gente, estavam com as listas prontas, era uma parceria que estava dando certo. (DIÁRIO, 15 de abril de 2016)

Aproveito este momento para fazer um balanço entre o que os interlocutores da escola e do centro de saúde disseram acerca desta parceria. Raul tocou em uma controvérsia importante acerca da parceria entre escola e centro de saúde. Para ele, esta parceria foi ótima, apesar de pequenos contratempos, disse gostar de trabalhar com as escolas. Mas não foi assim para todos os interlocutores. A Luana, a mãe que falei ainda a pouco, também professora e que trabalhou de perto com a vacinação do HPV, disse não achar a parceria positiva e que as vacinas deveriam ficar na saúde mesmo:

Luana: Eu acho que deveria deixar na saúde. Não deveria ter trazido esse momento para a escola, aliás, eu acho que nada devia vir para cá, toda questão de saúde eles trazem para a escola. A campanha da dengue, por exemplo, os professores trabalharam isso aqui com as crianças, não que a gente não tenha a obrigação de trabalhar, mas eu acho que a saúde deixa de fazer o papel dela e acaba imputando para gente fazer esse trabalho. Então é vacinação, é questão de cárie dentária, tudo acaba aqui na escola. (...) Tem um professor que falou, "Eu não vou tocar no assunto de HPV, porque eu não vou falar para o aluno sobre relação sexual".

Natália: Então essa parceria...

Luana: Eu não concordo! Até tem outro detalhe, quando a saúde manda algo pra cá, os profissionais ficam olhando a gente trabalhar, eles quase não se envolvem, eles querem que a gente faça tudo, eles não querem fazer nada a mais do que vieram fazer. (DIÁRIO, 30 de março de 2016) 
Voltei essa mesma questão para Fernanda, a coordenadora da escola do Gama, produtora das listas, e ela foi pontual ao falar dos ganhos para a escola quanto à entrada da vacina por ali:

Natália: O que vocês ganharam com a vacinação do HPV na escola?

Fernanda: Muito choro, muitas meninas virando a cara pra mim: "Doeu, por mais que você falou que eu ia ficar bem, tá doendo muito o meu braço". E eu respondia: "Daqui a pouco passa". Foram muitas caras feias.

Natália: E só?

Fernanda: Só. Mesmo assim eu me sinto... Sinto que havia necessidade de informar sobre a vacina. (DIÁRIO, 25 de agosto de 2016)

Fernanda não visualizava ganhos diretos para a escola em relação à vacina. Mesmo não sendo proveitoso, ela sentia que a escola precisava passar por aquilo ali, pois de uma maneira ou outra, era uma oportunidade de informar às meninas sobre a vacina, "assim ajudando com que elas se prevenissem" (DIÁRIO, 25 de agosto de 2016).

Pode-se presumir que o fato preponderante para levar essa vacina ao ambiente escolar, ouvido em campo de diferentes maneiras, era que, ao entrar com uma vacina na escola, esta passava por um valioso aproveitamento. Estar dentro de um centro de ensino era estar no lugar de contato direto com um dos públicos alvo da campanha do HPV (as adolescentes), logo, a vacinação tornava-se mais fácil, visto que não havia necessidade de deslocamento até um centro de saúde, como afirma Tereza, a técnica de enfermagem:

Vacinar nas escolas é o melhor caminho, pois as meninas da população alvo não têm o hábito de ir à unidade de saúde por não haver rotina para esta faixa etária. As salas de vacina fecham no horário do almoço e encerram as suas atividades às $17 \mathrm{~h}, 18$ horas, o que inviabiliza a ida dos pais às salas de vacinação, que não têm horários estendidos. Elas não funcionam aos sábados, a não ser que tenha alguma campanha de vacinação. (DIÁRIO, 15 de abril de 2016)

Os jovens em geral são vistos como desafios para o sistema de saúde, já que os pais têm mais dificuldades de levá-los ao médico. Talvez o trabalho de convencimento para os adolescentes seja maior do que aquele direcionado às crianças, no sentido de uma negativa ou mesmo desistência por parte dos jovens. Segundo a médica Mônica Levi, presidente da Sociedade 
Brasileira de Imunizações (SBIm), o Brasil "tem um programa nacional de vacinação de muito sucesso, mas algumas vacinas dos adolescentes acabam esquecidas". Se adolescentes frequentassem os centros de saúde, um benefício complementar, além das vacinas, poderia ser atingido. Esta visita seria uma oportunidade para o mundo biomédico oferecer outras prevenções e cuidados para com este adolescente.

Fecho a seção com a fala das alunas acerca da presença da vacina na escola, elas também experimentaram e ponderavam a presença da vacina ali. Seria a vacina um item pertencente ao universo da escola ou da saúde? Considero esta uma questão difícil, pois depende muito do referencial analisado. Em conversas separadas, algumas garotas responderam assim:

Ingrid: Eu já conversei com a minha mãe que eu não gosto de tomar vacina em escola, porque eu não confio. $\mathrm{Na}$ escola eu não gosto porque, assim, eu já vi uma mulher usar a mesma injeção em outra criança. (...) Por isso que eu não gosto, tem que ser uma agulha para cada aluno. Pra mim isso não dá certo.

Anna: Eu fico meio insegura na escola, porque eu não sei por onde passou aquela vacina. No posto, eu fico um pouco melhor, porque eu vejo a moça pegando. Na escola não, vem tudo numa caixa de papelão, não sei nem de onde veio. (DIÁRIO, 30 de março de 2016)

Parece que o fato de a vacina estar fora de seu ambiente institucional e ser manipulada longe dele, causava desconfiança e desconforto em algumas meninas. A maioria delas, nas entrevistas, demonstrou ter ambos os universos - escola e saúde - bem separados em suas concepções. Outras meninas entenderam que a vacina dentro da escola poderia ajudar a vida das famílias, as quais, por vezes, não têm tempo de levar os filhos ou as filhas ao centro de saúde:

Clarissa: Eu acho que vacina é da saúde, não tem nada a ver com a escola, mas favorece a escola, já que, tipo, tem gente que tem a vida muito movimentada, vai cedo trabalhar, tem que fazer um monte de coisa, aí não tem tempo de se cuidar. No final de semana, o posto não está aberto. Então, se estiver na escola, pode poupar tempo.

Flávia: Eu acho que tem um pouquinho a ver, porque eles [os profissionais da saúde] têm que participar da vida dos alunos.

Natália: E você, Bianca? 
Bianca: Eu acho que a escola serve para ensinar, a saúde para cuidar. Mas a vacina dentro da escola serve para a escola ajudar a criança, facilitar para os pais. (DIÁRIO, 30 de março de 2016).

Clarissa, uma menina de 12 anos, ao final do grupo focal, sintetizou de forma muito singela a vacina e a vacinação dentro da escola para ela:

Clarissa: A vacina tá na escola porque a escola incentiva a gente a fazer isso. Eu vejo a vacina como um presente, pois ele favorece a pessoa. Nada na sua vida é obrigado, tipo, se você não quiser tomar a vacina, você não toma. Mas, se não tomar, pode ter uma consequência. (...) Então eu acho que é como um presente, porque eles dão de graça. (...) Acho que deveria dar a vacina para todo mundo, até mesmo porque que é mais fácil um adulto tomar que uma criança, porque eles não têm mais medo.

Natália: Entendi! Quando a gente pensa em presente, a gente pensa numa...

Clarissa: Em uma coisa boa, em um chocolate, um celular bom, no skate elétrico que tô querendo. Aí a gente pensa na vacina, é bom para a saúde. (DIÁRIO, 30 de março de 2016)

Os campos saúde e educação parecem se afastar em alguns momentos, em outros, se imiscuir. Nem mesmo os profissionais da saúde ou da educação, envolvidos com a vacinação, sabem traçar essa linha, que se revelou tênue. Muito menos as alunas. Embora tida inicialmente como uma imposição por parte da Secretaria de Saúde, a vacina não poderia deixar de contar com os "préstimos" da escola, afinal, segundo Clarissa, "a vacina tá na escola porque a escola incentiva a gente a fazer isso". Raul conferiu boa parte dos créditos da vacinação à escola do Gama, já Fernanda não conseguiu ver nada além de trabalho extra e das caras feias das alunas diante da injeção. Seria a vacina um presente de fato? Para quem? Cabe perguntar.

O riso

Natália: E como foi a reação dos meninos no dia da vacinação de vocês? Rebeca: Ficaram rindo da gente. 
Bianca: Todas as meninas chegaram chorando lá na sala, aí eles acharam engraçado. Muitos meninos pensaram que eles iriam tomar a vacina também, aí ficaram preocupados. (DIÁRIO, 30 de março de 2016)

Por meio de risadas e brincadeiras os meninos marcaram sua presença no dia da vacinação. Mesmo com a escola direcionando a campanha do HPV às meninas, os rapazes não deixaram de participar dela. Mas por que tamanho distanciamento masculino e, por outro lado, dedicação às meninas?

A vacina do HPV tinha como premissa fundamental a proteção do colo do útero. O papel da vacina como uma solução tecnológica em evitar uma possível doença futura teve participação direta na visibilidade repentina do HPV no mundo e na necessidade de se proteger o útero (WAILOO et al, 2010). Tanto reproduzida pela campanha ou pelos atores envolvidos com a vacina (professoras, enfermeiras, alunas), esta premissa era sempre lembrada quando se falava de vacina. Conversei informalmente com Cleide, uma enfermeira que tive contato na escola, e ela ratificou a premissa:

Cleide: A vacina ela já nasce imposta para as meninas.

Natália: Sim, mas isso não tem implicâncias maiores?

Cleide: Exatamente, e aí qual é a justificativa que o manual [técnico] apresenta para ser só para as meninas, a meta não é diminuir a incidência do câncer do colo do útero?

Natália: Sim.

Cleide: Então, qual é o público-alvo? Quem tem o colo do útero são as meninas. Se elas forem vacinadas, boa parte dos meninos acabam sendo protegidos também. (DIÁRIO, 03 de junho de 2016)

A retórica da vacina sobre o corpo feminino ganhou as garotas também. Para a maioria delas, a justificativa dos meninos não se vacinarem era a mesma apregoada pela campanha, a presença ou não de um útero para se proteger.

Natália: Por que os meninos não ganharam vacina dessa vez?

Bianca: Porque isso é para câncer de colo de útero e eu acho que só mulher tem isso. (DIÁRIO, 30 de março de 2016) 
A premissa de proteção do útero pela vacina HPV apareceu sob um importante viés: a vacina era contra o câncer, não era contra uma DST. Antes, as causalidades das doenças nas mulheres estavam intrinsecamente ligadas à sexualidade feminina ou à histeria, ao desconhecido e misterioso corpo da mulher (ROHDEN, 2003), hoje não mais. A vacinação do HPV, na ótica da etiologia do câncer de colo de útero, parece ter sido despojada de qualquer referência à atividade sexual. O foco era a doença no colo do útero. Primeiro ponto da campanha. Tanto é que o discurso da vacina HPV é narrado como um direito, uma escolha, até mesmo um dever da mulher (GRAHAM, 2011), em virtude de se proteger um órgão menos visto, o útero, como diz o poema da abertura dessa dissertação. Esta restrição à mulher implica, mais uma vez, na antiga preocupação (controle) com o corpo feminino, porém, mais que isso, reforça nela o dever de se auto monitorar, de evocar os cuidados de saúde, se prevenir contra um risco possível, como é o câncer. A ela é solicitado que possa aderir a vacina, afinal, mulheres são tidas como consumidoras em potencial de produtos de saúde.

Neste contexto, a saúde, e não a doença, emergiu como objeto de intervenção médica e é o objetivo ativo dos consumidores e de suas práticas de consumo. Os indivíduos têm a responsabilidade moral não apenas de serem saudáveis, mas também de melhorar a si mesmos, seus corpos e suas vidas através do consumo de intervenções biotecnológicas disponíveis. Em uma rubrica de consumo, os produtos médicos são maneiras de alcançar uma aparência desejada, identidade, auto e grau de controle físico. Isto é o que Deborah Lupton denomina um desempenho eficiente do self ${ }^{52}$. (LUPTON, 1995 apud WAILOO et al, 2010, p. 155, tradução nossa)

Vacina é um produto de consumo privado antes mesmo de ser uma ferramenta da saúde pública. Esta se torna assim um produto que permite às meninas transformar suas identidades, seus corpos e seu futuro por meio da prevençao diante de um possível mal, afinal, “passando da normalização dos indivíduos para a personalização dos corpos, potenciais eus

\footnotetext{
52 In this context, health, not illness, has emerged as the object of medical intervention and the active goal of consumers and their consumption practices. Individuals have a moral responsibility not only to be healthy but also to improve themselves, their bodies, and their lives through consumption of available biotechnological interventions. In a consumption rubric, medical products are ways to achieve a desired appearance, identity, self, and degree of physical control. This is what Deborah Lupton terms an efficient performance of the self. (Lupton, 1995)
} 
futuros são trazidos para o presente através de biotecnologias como Gardasil ${ }^{53 "}$ (WAILOO et al, 2010, p. 125, tradução nossa).

Ao se remeter apenas às mulheres possuidoras de um órgão específico, a política vacinal do HPV tornou-se muito específica em relação ao sexo biológico das pessoas, ao incluir apenas mulheres. Tipos de gêneros ou de identidades sexuais foram afastados da discussão vacinal. O que marca, especialmente, o acesso à vacina aos homens e aos gays. Este era outro ponto problemático da campanha do HPV.

Segundo as pesquisadoras como Wailoo et al (2010) e Graham (2011), esta abordagem deixou os homens, em geral, fora do ciclo de transmissão do vírus ou deixou de representá-los como um das partes do mundo do HPV (BAER, 1997 apud WAILOO et al, 2010, p. 82, tradução nossa). A eles foi relegada a posição de "pano de fundo, apenas como 'pais, espectadores, protetores/defensores, coletores e guardiões de fato, e responsáveis pela aplicação da lei ${ }^{54 » "}$ (LOCOCK; ALEXANDER, 2006 apud GRAHAM, 2012, p. 59, tradução nossa).

De acordo com Rohden (2003), não se pode deixar de dizer que estas questões de divisão de papéis - neste caso, mulheres vacinadas e homens espectadores - estão centradas na dimensão das relações de gênero, o que se baseia no fato das mulheres terem (e ainda têm) passado por um longo processo histórico que envolveu a medicalização dos seus corpos e comportamentos, sobretudo sua reprodução e saúde.

Como enfatizam Graham e Mishra (2012), a identidade de gênero fica centrada na posse de certo órgão, excluindo todos os outros, o que acaba por dar à vacina um teor heteronormativo, pelo fato de enfocar as relações sexuais heterossexuais para o contágio do vírus, não englobando as relações homossexuais que ocorrem entre homens, especialmente.

A descrição da vacina contra o HPV como profilaxia tem se concentrado quase exclusivamente em seu papel na prevenção do câncer cervical, ignorando os cânceres penianos, anais e orais. Esse silêncio é racionalizado por estimativas epidemiológicas (ou seja, a maior prevalência de câncer cervical), embora tenha tanto a ver com homofobia e moralidades sexuais (Epstein, 2010). Esta marcação heteronormativa e a

\footnotetext{
${ }^{53}$ From the normalization of individuals to the personalization of bodies, potential future selves are brought into the present through biotechnologies such as Gardasil

54 On the other hand, remain in the background as 'parents, bystanders, protectors/supporters, gatherers and guardians of fact, and deciders or enforcers'.
} 
comercialização da vacina contra o HPV sustentam conceitos clínicos específicos de identidade de gênero centrados na posse de um colo uterino. A posse de uma parte do corpo biológico restrito à mulheres, é o critério clinicamente aprovado para inclusão do recorte de imunização patrocinada pelo governo. O efeito líquido é a rotulagem da imunização contra HPV como "a vacina da menina" ${ }^{55}$. (GRAHAM; MISHRA, 2012, p. 59, tradução nossa)

O termo "heteronormatividade" é uma normativa sexual e foi utilizado primeiramente por Michael Warner (1991). Para ele esta é uma denominação contemporânea para o dispositivo histórico da sexualidade que possui um objetivo: "formar a todos para serem heterossexuais ou organizarem suas vidas a partir do modelo supostamente coerente, superior e "natural" da heterossexualidade" (WARNER, 1991 apud MISCOLKI, 2009, p. 153). Posteriormente, a feminista Adrienne Rich (1993) publicou um artigo em que fazia referência a esse conceito, daí o termo se expandiu. Ele se estabelece de diversas maneiras na sociedade e se apresenta às instituições, ao Estado, às mulheres e homens, como

Uma expressão compulsória heterossexual, transformando em única forma desejável a relação mulheres-homens. A heterossexualidade é mais cruel ainda com as mulheres, (...) pois faz com que a experiência lésbica seja percebida através de uma escala que parte do desviante ao odioso ou a ser simplesmente apresentada como invisível. (...) Tanto quando faz do reforço da heterossexualidade para as mulheres um meio de assegurar o direito masculino de acesso físico, econômico e emocional a elas (RICH, 1980, p. 21).

À sobra da heteronormatividade, ficaram os rapazes, suscetíveis ao HPV, mas à parte de uma política de sexualidades, política essa que lhes colocam como invisíveis ao marketing médico e ao debate público. O vírus HPV frente ao câncer anal e a homossexualidade conforma-se em uma questão indiscutível dentro da campanha do HPV (WAILOO et al, 2010).

\footnotetext{
55 The depiction of HPV vaccine as prophylaxis has focused almost exclusively on its role in preventing cervical cancer, ignoring penile, anal and oral cancers. This silence is rationalised by epidemiological estimates (i.e. the higher prevalence of cervical cancer), although it has as much to do with homophobia and sexual moralities (Epstein 2010). This heteronormative marking and marketing of the HPV vaccine in the first years of its introduction comes to the foreground in the clinical assumption that HPV immunisation for girls could ensure herd immunity. The rationale and administration of HPV immunisation sustain specific clinical concepts of gender identity centred on the possession of a uterine cervix. Possession of an 'innately female' biological body part is the clinically endorsed criterion for inclusion in a government-sponsored immunisation cohort. The net effect is the labelling of HPV immunisation as 'the girl vaccine'.
} 
Segundo Epstein (2010 apud WAILOO et al, 2010), este movimento pela visibilidade de outros grupos frente à vacina HPV iniciou-se em 2009, nos Estados Unidos, a partir de homens homossexuais que pediram atenção para as doenças do HPV que eles poderiam vir a desenvolver, tal como câncer anal. Segundo este autor, a importância de se contestar a vacina a partir deste viés faz com que "o interesse dos homens gays na prevenção do sexo anal sirva nesta discussão para marcar uma dialética da inclusão e exclusão que muitas vezes caracteriza as novas tecnologias médicas ${ }^{56 "}$ (EPSTEIN, 2010 apud WAILOO et al, 2010, p. 94). Isto faz das vacinas evocações de políticas de cidadania plena e sexual.

Em que condições sociais permanecem certas coisas desconhecidas e certos tópicos não estudados? Como argumenta Robert Proctor, responder a essas perguntas exige que a epistemologia (o estudo de como sabemos) seja complementada pela agnotologia (o estudo do que não sabemos e por que não chegamos a conhecê-lo). Neste caso, uma agnotologia do câncer anal aponta para os vínculos ideológicos que foram forjados nas últimas décadas entre um grupo medicamente marginalizado, um órgão socialmente invisível (o ânus) e uma prática socialmente estigmatizada (sexo anal). O resultado é tornar o câncer anal "o grande [tema] indiscutível" no discurso público sobre o HPV ${ }^{57}$ (WAILOO et al, 2010, p.95, traduçâo nossa).

Enquanto política vacinal, o ideal seria que a vacina HPV fosse tida como padrão para todos os jovens, independentemente da identidade sexual, porém, hoje esta política marca-se por estar voltada para o mundo feminino, onde quase todos os personagens que envolvem a vacina são mulheres - professoras, mães, enfermeiras, alunas. A face pública da vacina HPV é jovem, ativa, multiétnica, bem informada e com poder de se proteger, ou seja, é a mulher contemporânea que se espera (EPSTEIN, 2010 apud WAILOO et al, 2010).

\footnotetext{
${ }^{56}$ Gay men's interest in the prevention of anal cancer therefore serves to mark one side of the dialectic of inclusion and exclusion that often characterizes new medical technologies.

${ }^{57}$ Under which social conditions do certain things remain unknown and certain topics unstudied? As historian of science Robert Proctor has argued, answering such questions demands that epistemology (the study of how we know) be supplemented by agnotology (the study of what we don't know and why we don't come to know it). 7 In this case, an agnotology of anal cancer points to the ideological linkages that have been forged in recent decades between a medically marginalized group, a socially invisible organ (the anus), and a socially stigmatized practice (anal sex). The result is to make anal cancer the "great undiscussable" in public discourse about HPV.
} 


\section{Foto 8}

Mulheres, jovens, alunas - Estes eram os corpos vacinais.

Dezembro, 2015.

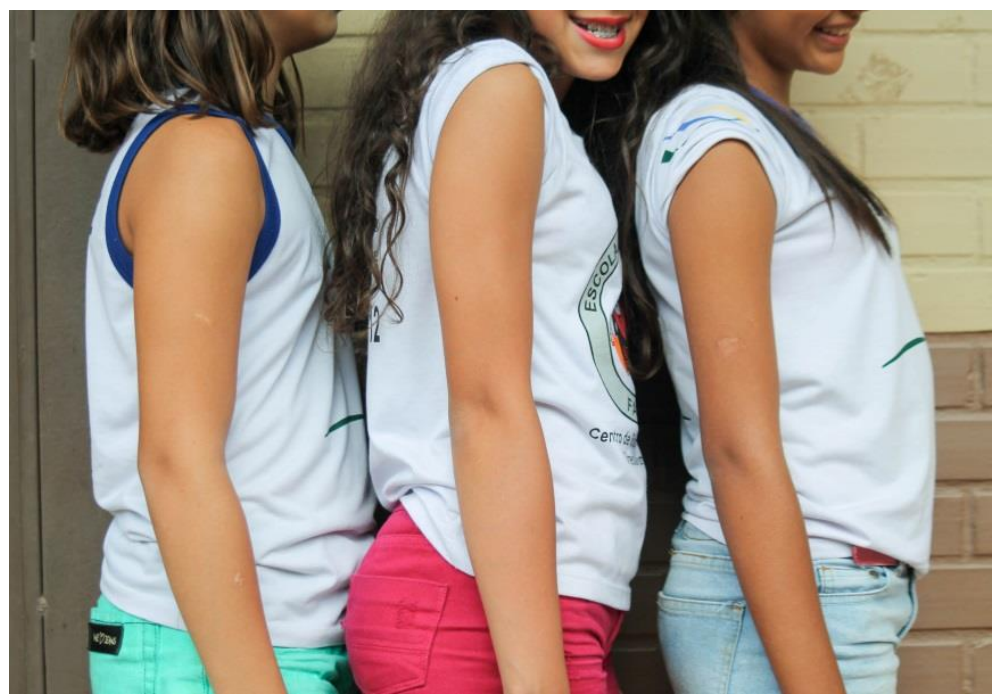

Ao contextualizar a campanha do HPV em relação às ênfases na mulher e ao esquecimento dos homens, eis que na escola do Gama, em analogia e guardadas as ressalvas, encontrei divisão de gêneros parecida. Como destinatárias da vacina, as meninas foram chamadas diversas vezes a se atentar para a importância da vacinação, a ouvir as explicações sobre o vírus HPV, a assistir palestras, levar comunicados para casa, dentre outras tarefas. Diferentemente, aos meninos, nada foi solicitado. Antes da vacinação das meninas, alguns meninos me contaram que até ouviram em sala de aula as professoras falando alguma coisa sobre HPV, nada mais foi relatado. Caso ocorressem palestras, como na antiga escola de Inês, os meninos também não foram chamados a participar destes momentos. Como visto ainda pouco, a eles coube a indiferença por parte da política vacinal do HPV.

Entretanto, os meninos não deixaram de participar de alguma forma deste processo. O riso, a curiosidade, a brincadeira, a zoação foram marcadores da presença dos meninos na vacinação. No "Dia D", observei alguns garotos na janela espiando as colegas ou "tirando onda", como eles costumavam dizer. Com o intuito de entender se isto era constante, lembrome sempre de fazer a seguinte pergunta para as interlocutoras "Como foi a reação dos meninos no dia que você se vacinou?". As respostas eram quase sempre parecidas, como a de Raiane, 12 anos, do sétimo ano, a qual entrevistei individualmente:

Raiane: Eles zoaram a gente, porque nós gritamos na hora da vacina. Sabe o que é? Tem bastante bullying nessa sétima série. 
Natália: Com as mulheres?!

Raiane: Principalmente com a gente! Mas com todo mundo também. (...) Os meninos riem de tudo. Ficam maiando a gente, colocam apelido, zoam mesmo. (...) Eu devolvo tudo na lata.

Natália: Eles não têm jeito, né? Você acha que eles sabem que existe essa vacina ao menos?

Raiane: Nem eu mesmo que tomei sei para que serve, imagina eles. Eles podem até saber que todas as meninas devem se vacinar, mas porque e pra que serve, eles não sabem. (DIÁRIO, 3 de abril de 2016)

A risada para os meninos é mais uma forma de chamar a atenção e "um implemento multifacetado de extraordinária importância na cultura contra escolar" (WILLIS, 1991, p. 45 apud PEREIRA, 2016, p. 171). São elas que buscam tornar as relações menos tediosas dentro da sala de aula. Quanto à vacinação, esta se revelou uma oportunidade, no universo das situações escolares, onde se era possível "estabelecer ou reforçar tanto vínculos de amizade como de inimizade" (PEREIRA, 2016, p. 177). Aqui os risos acompanharam as zoações. Estas, segundo Pereira (2016), são chaves valiosas para se compreender como se dão as relações entre alunas e alunos e a escola.

A relação de brincadeira é uma combinação singular entre cordialidade e antagonismo. O comportamento é um comportamento que, em qualquer outro contexto social, expressaria e provocaria certas hostilidades; mas esse comportamento não é suposto ser levado à sério e, na realidade, não é levado à sério. (RADCLIFFE-BROWN, 1989, p. 153 apud PEREIRA, 2016, p. 177)

Tudo depende, na verdade, do tipo ou da intensidade da brincadeira ou zoação. Dos meninos com quem conversei, muitos zoaram as meninas não só para serem implicantes com elas, mas havia algo por trás. Pereira (2016) traz à discussão tipos de masculinidades reforçadas na escola, as quais evocam um padrão de comportamento considerado o mais adequado a todos os meninos, e as relações de jocosidade é um deles. Percebi que era esperado que os meninos não se envolvessem emocionalmente frente à sensibilidade e sentimentos das meninas às vacinas, resguardando-se, então, nas brincadeiras,

Com isso, haveria a intensificação da questão da heteronormatividade, discutida por Judith Butler, entre meninos e meninas, "tornando-os durões e tornando-as submissas". As práticas de zoeiras, com base nessa perspectiva, demarcariam fronteiras de gênero. (PEREIRA, 2016, p. 195) 
O ato de zoar o outro é manejado por muitos como "poder" de se produzir risadas na turma ou se auto afirmarem "palhaços" perante todos. O autor traz esta figura com base nos estudos de Peter McLaren (1991 apud PEREIRA, 2010, p. 172), o qual marca o "palhaço" como pessoas que ridicularizam os outros por meio do humor, "através da zombaria ou parodiando os pontos fracos dos outros, o palhaço de aula pode ser visto como alguém que joga com a inconsistência e ambiguidades (...) das metáforas sociais” (McLAREN, 1991 apud PEREIRA, 2016, p. 172).

Eu encontrei alguns destes na escola do Gama, eles eram os que geralmente assumiam o maior destaque nas brincadeiras entre os colegas. Inclusive, comigo, no dia da "foto de parede". Descrevo este dia no capítulo dois, quando eu estava tirando fotos das pichações e um garoto de dentro da sua sala de aula me perguntou em alto tom se eu estava "tirando foto de parede". Neste dia, fui alvo das brincadeiras de um destes "palhaços", o que me rendeu a risada da turma no momento e uma semana de zoação.

Algumas meninas, por sua vez, não aceitavam silenciosas as brincadeiras dos colegas. Respondiam devolvendo a zoação, como Clarissa relatou ter falado ao colega "E você que é feio, nem com vacina melhora!” (DIÁRIO, 30 de março de 2016). Outras preferiam não retrucar na hora, preferindo ir reclamar com a professora ou com a Direção. Para Pereira (2016), as relações de zoação atendem uma lógica de reciprocidade, pois implica em receber e devolver a chacota.

Articulavam-se, portanto, as três obrigações das relações da dádiva enunciadas por Mauss: o dar, o receber e o retribuir. Contudo, deve-se ressaltar que as zombarias realizadas pelos alunos e alunas poderiam ter múltiplas determinações e implicações. Ou seja, em certos momentos a gozação poderia ser amistosa. (...) Em outros, no entanto, a zoeira poderia ter a intenção explícita de agredir quem quase sempre era considerado em rival. (...) Assim, como ressalta Marcel Mauss, ao refletir sobre os dois sentidos que a palavra gift adquiriu na língua inglesa e na língua alemã, como presente na primeira e veneno na segunda, o presente dado nas relações de dádiva carregaria consigo a incerteza sobre sua natureza boa ou má; da mesma forma, as gozações também ostentariam uma indefinição sobre seu caráter. (PEREIRA, 2010, p. 179)

Porém, não apenas o tom das chacotas permeava o universo masculino. Alguns meninos que pude conhecer e com quem pude conversar com mais calma, se mostraram preocupados e mesmo indiferentes à dureza que deles era esperada. Falaram da vacinação das 
amigas de modo suave como é o caso de Henrique, de 11 anos, do sexto ano e de Diego, de 13 anos, do sétimo ano:

Henrique: Eu achei a vacinação legal porque elas estavam se cuidando.

Natália: Algumas meninas me falaram que quando elas voltavam pra sala, alguns amigos ficavam zoando. Como foi isso?

Henrique: Bem, eu não gosto de zoar as meninas, eu gosto de ficar ao lado delas, de conversar. Eu não posso dizer que eu tenho amigos [homens], porque infelizmente eu não tenho mesmo, aí eu converso com as meninas e ando com elas, então se eu as zoar, eu perco minhas amizades, entende? (...) Eu gosto de saber que as minhas amigas estão bem, estão com boa saúde, não estão com nenhum problema, nenhuma doença. (DIARIO, 23 de junho de 2016).

Natália: Diego, você lembra como foi essa questão da campanha do HPV aqui na escola?

Diego: Lembro. Primeiro chamaram só as mulheres e eu fiquei assim "ué, os meninos não serão chamados não?". Aí alguns colegas meus: "Não, isso aí é só para menina mesmo". Aí eu perguntei, pesquisei na internet, tentei tudo para saber se não íamos tomar. (...)

Natália: Quando eu conversei com as meninas, elas me contaram que quando voltavam para as salas os meninos ficavam zoando. Você se lembra disso?

Diego: Sim. Foi verdade. Eles são machistas demais. Ficaram falando coisas do tipo: "Ah! Você tomou vacina e tá chorando", e não sei mais o que. Falaram também sobre sexo... Mas eu fui fazer o meu deverzinho que é muito melhor. (...) Caso houvesse necessidade, eu tomaria essa vacina, mas, caso contrário, não. (DIARIO, 23 de junho de 2016).

Henrique e Diego, mesmo se diferenciando dos outros meninos quanto à zoação das meninas, em contrapartida, demonstraram ter posições semelhantes ao restante dos pesquisados quanto à mulher se cuidar e também revelaram não ter conhecimento sobre a utilidade da vacina ou sobre o vírus HPV. Os meninos, acusados de não cuidarem da saúde, por preguiça ou machismo, tinham nas meninas a visão de mais preocupadas e cuidadosas com o corpo. Assim, era até explicável que a vacina ficasse apenas à disposição das meninas. Conforme Vera, uma professora do colégio, mãe de aluna e favorável à vacina, o machismo era de fato o que afastava os homens dos assuntos de saúde:

Natália: Por que você acha que os meninos não foram contemplados com essa vacina? Você entende que para eles também ajudaria? 
Vera: Eu não tenho a informação de como ela seria importante para o corpo masculino, não sei te dizer detalhes e nem sei se existe a vacina do HPV masculina, diferente da feminina. Acho que por eu ter filhas mulheres, eu apenas me importei com a vacinação delas, talvez se eu tivesse um menino, saberia. Mas eu acho que está mais na cabeça da mulher de se cuidar. (...). O país ainda é muito machista, e dentro desse machismo, o homem acha que não precisa usar a camisinha, se prevenir de nada, então a mulher se cuida mais, ela vai mais ao médico, eu acho que a mulher ela é mais responsável pelo corpo dela sim. (DIÁRIO, 10 de maio de 2016).

Numa reunião de pais que frequentei já no final do segundo bimestre escolar, conheci Dona Maria, de 50 anos, avó de Jéssica, uma estudante do sétimo ano. Ao conversarmos sobre os cuidados com a neta, ela esboçou uma ideia parecida com a de Vera:

Dona Maria: Eu acho que a vacina tinha que chegar também para os homens. Os homens tinham que se cuidar como nós, mulheres. Eu sempre falo isso. É que nem eu falo em casa: "As mulheres se cuidam mais do que os homens". Talvez seja um machismo deles, não sei, mas deveria ser o mesmo acompanhamento para as mulheres e para os homens.

Natália: A gente vê pouco eles se cuidando?

Dona Maria: Vê pouco. (...) Meu marido mesmo, ele não faz nada pra se cuidar, eu brigo com ele, eu falo com ele "é pra se cuidar, não é assim, tem que ir ao médico". A saúde dele é muito boa, acho que por isso ele não vai ao médico. (...)

Natália: Dona Maria, me conta mais, estou achando muito interessante esse nosso papo. Por que a mulher se cuida mais? O que leva a gente a se cuidar mais?

Dona Maria: Eu acho que a mulher é mais inteligente. Porque a mulher se cuida mais, ela se preocupa com a prevenção, cuida de todos os exames dela, porque ela sabe que se ela não fizer, lá na frente, pode ter um problema sério de saúde. (DIARIO, 20 de agosto de 2016)

Para os profissionais de saúde e da escola que contatei, as despesas com o custo das vacinas era a causa principal para a não vacinação dos homens. Fatores como proteção do útero ou machismo eram dados secundários. André, o coordenador de apoio da escola e um dos mais antigos servidores de lá, o qual acompanhou de perto a vacinação do HPV, tinha uma opinião convicta sobre a vacinação:

Natália: André, por que os meninos não precisam se vacinar?

André: $\mathrm{Na}$ época foi questionado muito isso. Eles acharam [Secretaria de Saúde] que nas meninas a complicação do HPV é maior, dá problema de câncer do colo do útero. 
Mas, o principal, o governo não tinha dinheiro para vacinar todo mundo, o orçamento era limitado. (...) O ideal seria vacinar todos, mas eu repito o que eles falaram na época: "Essa vacina não é barata, é uma vacina cara, ela vem de fora, é importada, temos um orçamento pequeno". Eu fui na palestra, participei mesmo, lembro o que eles disseram. (...) Eu lembro que na época os dados da campanha eram só para as meninas, foi colocado isso para gente. Os meninos não tiveram acesso a essa informação, os cartões de vacina eram só para as meninas e realmente eles [Secretaria de Saúde] deixaram os meninos de fora mesmo.

Natália: Você acha isso um pouco prejudicial?

André: Sim, para o mundo real é ruim porque os meninos tem que ter essa informação, até mesmo porque as meninas não vão para a atividade sexual sozinha, tem que ter os meninos. E quanto mais meninos preparados com essas informações, mas eles também poderiam tomar decisões pensadas. (...) Houve um déficit de informação. (DIÁRIO, 14 de abril de 2016)

André, além de explicar o fator financeiro para restrição da vacina HPV nos meninos, ainda trouxe uma resposta para a exclusão destes frente à informação e participação, mesmo que indireta, das explicações sobre o vírus ou sobre a vacina. Colocou em igualdade meninos e meninas quando afirmou que "meninas não vão sozinhas para a atividade sexual", assim, atendendo ao anseio de não responsabilização única da mulher, da mudança no olhar sobre a medicalização do corpo feminino e conferindo aos homens o envolvimento neste processo de conhecimento e não diferenciação dentro das políticas públicas.

A duração deste dia da vacina não foi de horas, ele é resultado de construções do passado e reverbera ainda hoje. O que se viu presente nas narrativas e nas considerações deste capítulo são possíveis caminhos, e não únicos, para se pensar o fenômeno da vacinação do HPV, que tende a separar as pessoas em lados opostos, sejam nas listas, sejam nos papéis de gênero, sejam nas risadas e gozações.

O que os eufemismos dentro da política de vacinação do HPV querem esconder? Ou mesmo revelar? O ideário da prevenção, o sim, o não, o riso, seriam eles mecanismos desta política vacinal? Há muito ainda por se conhecer. Inclusive, no próximo capítulo, eu darei voz 
às mães e pais que foram participantes ativos no processo vacinal, os quais adicionam ainda mais dados à vacinação. De modo geral, o dia da vacinação, para além de analítico e reflexivo, serviu às mães para fomentar os sentidos do cuidado que elas, eufemisticamente, deferiram às suas filhas. 


\section{Capítulo 4. OS SENTIDOS DO CUIDADO}

$V$ amos ficar imunes amigos,

Para evitarmos as doenças.

Usufruimos de algo sabido

E da nossa inteligência.

Às vezes ainda vemos casos

Por falta de compreensão,

Porém, vamos ser civilizados

E aceitar a boa vacinação. 


\section{$O$ cuidado frente à vacina do $\mathrm{HPV}$}

Algumas mães revelam maior crença no efeito terapêutico da vacina que seus filhos tomam no curandeiro do que a vacina na unidade sanitária. (...) Enquanto a vacina do hospital serve para proteger contra uma determinada doença física, a do curandeiro, além das doenças físicas, protegem contra feitiçaria e inveja. (...). O "fechar o corpo" significa vacinar ${ }^{58}$ a criança contra toda obra de feitiçaria, inveja e maus espíritos. Geralmente os pequenos cortes, conhecidos também pelo número "onze" por deixarem evidências idênticas a essa letra, são feitos nos pontos considerados mais vulneráveis à agressão externa espiritual ou física: a cabeça, o peito, as costas, as articulações dos membros e nas zonas dos rins. A partir do momento que uma criança tem seu corpo supostamente "fechado", ela está sob a proteção dos espíritos bons, geralmente são os espíritos dos seus antepassados. Contudo, essa proteção depende muito do comportamento dos pais, em agradar aos antepassados. Se eles infligirem alguma norma, a criança poderá ficar doente. (CHIDASSICUA, 2011, p. 146)

Não há duvida que uma das faces do cuidado com as crianças e adolescentes passa pela saúde e pela proteção. Desse modo, percebemos que tanto a infância quanto a adolescência são hoje compreendidas como categorias construídas historicamente, tendo, portanto, múltiplas configurações. Estas fases da vida são compreendidas e (re)significadas de acordo com a cultura da qual se fala. Logo, o tipo de cuidado e zelo depende do contexto cultural também. Cuidar ou proteger pode ter a ver com o meio físico ou espiritual, ou mesmo concomitante, pode ser expor a algo ou também resguardar a depender do referencial.

A comunidade descrita por Chidassicua localiza-se no distrito chamado Mopeia, o qual fica na província de Zambezia, em Moçambique, sudeste da África. Esta comunidade chamou a atenção do pesquisador em virtude de possuir elevadas taxas de mortalidade infantil - setenta mortes para cada mil crianças de zero a cinco anos - mas, principalmente, por apresentar um sistema de cuidado da saúde imiscuído entre as práticas biomédicas e o sistema sociocultural. Com o objetivo de diminuir esta alta taxa, Moçambique e os parceiros - UNICEF e OMS realizam constantes campanhas de educação sanitária, inclusive campanhas de vacinação. A primeira campanha nacional de imunização ocorreu em 1976 e logrou alguns êxitos como a erradicação de doenças como a Malária (CHIDASSICUA, 2011). Mas, o fato importante aqui é que a estratégia de imunização é uma prática relativamente "nova" para a região e é

\footnotetext{
${ }^{58}$ Vacinar representa as incisões que o curandeiro faz no corpo de um paciente, segundo o autor.
} 
constantemente combinada com as práticas locais e logo, revela aspectos interessantes quanto à concepção do termo "vacinação".

As crianças são vacinadas tanto pelo sistema biomédico nacional, com vacinas contra malária, tétano, febre amarela, dentre outras, e também submetidas à vacinação espiritual, realizada por um curandeiro do grupo, como condição primordial para a proteção integral de seus corpos. E mais, há a interpelação pela ação dos pais, que são responsabilizados pela saúde dos filhos, caso não procedam de forma correta em seus caminhos e escolhas. Ser uma mãe cuidadosa é proporcionar esses dois tipos de vacinas aos filhos, de acordo com Chidassicua (2011).

Inclusive, quando uma criança morre, além da roupa que é jogada no cemitério, joga-se fora também toda a documentação da criança (CHIDASSICUA, 2011), dentre ela, o cartão de saúde e vacinas, "na verdade as mães tomam essa atitude porque sabem de antemão que irão ser repreendidas por não cumprirem o calendário vacinal dos filhos como preconizado pelos médicos, o que poderia, na cabeça delas, justificar aquela morte" (ibid., p. 145). Em relação ao nome e função das vacinas, o autor aponta que quase todas as mães desconhecem esses fatos. Mas todas sabem que elas servem para proteger seus filhos.

O mais interessante é que essa vacinação espiritual também deixa marcas que atestam de alguma forma a proteção do corpo bem como nossa marca de vacina no Brasil como apresentada no capítulo um. Percebe-se assim, que saúde e doença não estão apenas ligadas às questões biológicas, mas às socioculturais, a como as pessoas pensam e interpretam suas próprias escolhas, suas doenças, e que elementos evocam para que essa lógica seja satisfeita.

Essa história serve de analogia para o que será apresentado adiante. Em outro continente diferente do nosso e também em outra cultura, pode-se perceber que algumas semelhanças em torno da vacina permanecem, como proteger os filhos de um mal. O cuidado em relação à saúde dos filhos é a retórica principal que ouvi de praticamente todas as mães e pais, porém, cada um a sua maneira. As mães e pai (escrevo no singular porque foi apena um) contatados, embora pudessem ter sido apresentados no capítulo anterior como participantes do dia da vacinação de forma indireta, afinal não estavam presentes em sala, mas sim materializados nas decisões acerca da vacinação, foram trazidos a este capítulo. Preferi reservar a eles um capítulo exclusivo, devido a densidade de dados etnográficos. 
Neste capítulo quero trazer três componentes à cena. As mães dos cartões de vacina completos, a mãe que não quis vacinar contra o HPV e, discutir um pouco sobre os fatos e valores que estavam por trás da ótica desses dois grupos. São mães e pais os atores sociais principais das discussões aqui.

A implementação da vacina do HPV no Brasil se revelou um processo complexo, permeado de controvérsias científicas e públicas. O processo repercutiu mobilizando diferentes atores sociais como a mídia e a população, especialmente as adolescentes (público direto) e seus familiares (público indireto). A vacina apresentou uma série de dúvidas sobre os efeitos adversos e segurança, além de questionamentos de religiosos por se tratar da imunização de meninas antes de iniciarem a vida sexual. Estas características denunciam, mesmo timidamente, algumas mudanças de atitudes que desafiam o princípio da vacinação universal.

Foram muitos os dados etnográficos encontrados que reverberaram outras questões densas, afinal, por trás de cada lógica representada em uma menina, lá estava a figura dos pais. O cuidado e a prevenção em relação aos corpos de suas filhas foram a justificativa dada por cada uma das seis mães e um pai que consegui contatar para entrevistas semiestruturadas, sejam apoiadores ou não da vacina do HPV.

\section{"Mãe da vacina"}

Vera: Então, eu acho muito importante vacinar. E eu sou do pensamento "se Deus deu a inteligência e o médico aprendeu, a gente tem que usar tudo o que pode". Hoje tem vacina de não sei o que, de pneumonia, de caxumba. Minhas meninas tomaram tudo, ano passado também, a da gripe.

Natália: Então você é uma mãe adepta...

Vera: Sou a mãe da vacina! (...) Eu até pensei que você iria querer ver o cartão das meninas, eu tirei uma foto [e me mostra a foto no celular com o carimbo e a data das doses]. (DIÁRIO, 10 de maio de 2016)

Essa mãe era professora da escola, tinha 42 anos, mãe de duas meninas - Sofia e Anita, casada e sem religião definida. Consegui entrevistá-la numa tarde atípica, onde a maioria dos alunos havia sido dispensada devido à falta de água no colégio. Entretanto, como ela precisava aplicar uma atividade, ela não concordou em liberá-los mais cedo. Conversamos na sala de 
artes a pedido seu, já que estava vazia, pois a janela dali ficava voltada para sua sala, local em que ela podia "ficar de olho na turma". Vera representava a maioria das mães que conheci e pude conversar durante a pesquisa, que eram as mães que apoiavam as vacinas em geral. As ideias dela eram instigantes para entender a lógica da vacinação das filhas e filhos, afinal, vacinar e ter o cartão em dia era sinônimo de ser "boa mãe" para ela.

Vera me contou que a vivência das questões de saúde com as filhas, no seu caso, pertencia ao pai e à mãe, mas principalmente a ela. Sua filha Sofia, a mais velha, estudava em uma escola particular no Gama - as escolas particulares também receberam a campanha, e foi lá que a menina tomou a vacina, na época com 11 anos - Anita, a caçula, ainda não se vacinará. Vera se preocupou em ler bastante sobre a vacina, relatou que ouviu muitas histórias "que fulano tomou e desmaiou, que ficou com a perna dura", mas decidiu vacinar sua filha depois que conversou com o médico da família:

Vera: Eu perguntei para o médico e ele disse que era para tomar, então ela tomou as três doses, e foi na escola.

Natália: Esse é o médico da família?

Vera: Sim, é o pediatra delas, é o mesmo desde sempre.

Natália: Que interessante!

Vera: Hoje ele já é amigo, não é mais só o pediatra, participa de churrasco lá em casa. Natália: Então qualquer coisinha é só perguntar?!

Vera: Sim. [risos nossos] (DIÁRIO, 10 de maio de 2016)

Ratificada pelo "médico-amigo", a vacina para Vera era uma obrigação, "É uma forma de cuidar. Se eu tenho que cuidar e zelar pelo meu filho, a vacina é uma maneira dessas. É obrigação dos pais! Minhas filhas tomaram todas, as pagas e as não-pagas". Assim Vera se posicionava.

Em outro momento, numa tarde de dezembro na escola, tive a oportunidade de conhecer Luíza, mãe de aluna que tinha ido à escola para saber sobre o desempenho da filha na disciplina de Geografia. Eu estava em sala conversando com algumas meninas, quando Luíza chegou. Após falar com a professora, eu fui até ela, expliquei a pesquisa rapidamente e pedi para conversar. Ela gentilmente me cedeu alguns minutinhos, e ainda chamou sua filha Érica, de 12 anos, com a licença da professora, para participar também. Luíza tinha 38 anos, era maranhense e dona de casa, não por gosto, mas porque estava desempregada. Assim como 
Vera, tinha orgulho de falar que o cartão da filha estava completo e de como cuidou para que os filhos crescessem com saúde:

Eu sempre me preocupei de vacinar todos eles, bem certinho. Mesmo a gente morando no Goiás, as tias deles moravam ali no Leste [um dos setores do Gama], então eu aproveitei e fiz o pré-natal todo aqui no Gama. Fiz, desde cedo, todo tipo de exame. Tanto o menino, como as meninas, todos têm os exames certinhos. Graças a Deus. Eu sempre falo pra eles, eu me doei para vocês, sempre me virei, trabalhando de feirante, para poder cuidar, para não deixar vocês jogados. Eu sempre falo "se meus filhos procurarem outro caminho, eu não me culpo, porque eu sempre dei o meu melhor". (DIÁRIO, 01 de dezembro de 2015)

Para Luíza, a vacina era uma proteção, era um dos cuidados que toda mãe deveria ter com os filhos, para além dos exames que começavam desde a concepção. A vacinação fazia parte de um todo global de cuidados aos filhos, o que incluía nesse rol, desde os exames do pré-natal, passando pela doação de si mesma na criação dos filhos, até aqueles dias, no trabalho que davam, como não querer estudar, dizia ela. Ter e utilizar o cartão de vacinas parecia auxiliar as famílias na tomada de decisão para a imunização de suas crianças. O cartão de imunização era um instrumento não só para lembrá-las dos retornos vacinais para o acompanhamento das crianças, mas era uma garantia do direito à imunização disponibilizada nos serviços de saúde.

Para além do cuidado, Luíza que era evangélica, não via sentido em não utilizar a vacina, já que o médico era abençoado por Deus, mas a pessoa também tinha que fazer sua parte no trato com a saúde:

O pastor da nossa igreja sempre fala da importância da mulher se cuidar, a mulher tem que se cuidar! (...) O médico é abençoado por Deus, mas você tem que fazer um tratamento, tem que fazer uma prevenção, você tem que fazer sua parte. (...) Eu sou da Universal, lá eles dão aquela visão bem forte, de que você tem que se cuidar, porque se você não se cuidar, depois vai perguntar "Cadê o Deus que você segue?". Onde o médico fala "eu não posso”, Deus age. (DIÁRIO, 01 de dezembro de 2015)

Percebi um papel importante da religião na vida de boa parte das mães que conheci, sobretudo, no processo de aceitação das vacinas, no sentido da crença em que Deus conferiu inteligência aos homens, e sendo a vacina uma criação vinda dessa dádiva, por que deixar de tomá-la? 
Para Luana, outra pessoa contatada na escola, mas agora professora, assim como Vera, o cuidado com suas filhas começou desde "bebezinho". Luana era mãe de duas meninas, tinha 40 anos, era divorciada, católica. "Eu que acompanho, levo ao médico, sempre estou de olho. Sou aquela mãe 'caxias', que vigia mesmo.” (DIÁRIO, 30 de março de 2016). Descartou logo de início o papel do pai nesses cuidados, dizendo que tudo acerca dos cuidados de saúde ficava a cargo dela. Vacinou suas filhas pensando na saúde delas e afirmou: "tudo que envolver a saúde das meninas eu vou fazer, se tiver outras vacinas, vão tomar todas". Portanto, para Luana, a vacinação em dia era uma obrigação das mães, principalmente.

Natália: Então, você é uma mãe a favor da vacina?

Luana: Sim, sempre! E eu acho que deveria ter mais vacinas, o governo deveria gastar mais dinheiro com esse tipo de coisa. (DIÁRIO, 30 de março de 2016)

Reforçando esse quadro, trago agora André. Ele foi o único pai (homem) da pesquisa que se dispôs a dar uma entrevista, o qual trabalhava na escola como coordenador de apoio, cargo criado pela Direção para poder readaptá-lo, depois de um quadro se forte estresse vivido. Quando perguntado sobre os cuidados de saúde em casa, ele se descreveu um pai participativo:

André: Essa questão de saúde lá em casa a gente compartilha, são os dois [pai e mãe], a gente sempre procurou levar ao hospital desde a época que a mãe ficou grávida, ela fez o pré-natal, e eu sempre acompanhei, sou um cara participativo, eu acompanho todas as consultas, desde a primeira ultrassonografia. Hoje, com as meninas, eu acompanho tudo, sempre junto com a mãe, levo para tomar todas as vacinas, aos pediatras, ao posto, nos [laboratórios] particulares se preciso for. A gente vem sempre acompanhando, aquelas vacinas que não têm no governo, a gente busca no particular. Logo, o caderno [de vacina] das três [filhas] estão atualizadíssimos.

Natália: É importante pra vocês?

André: É muito importante, porque é prevenção. (DIÁRIO, 14 de abril de 2016)

Foi André quem levou sua filha para tomar a vacina do HPV no posto, depois de combinar isso com sua esposa, porque o colégio anterior que a filha estudava ainda não oferecia a vacina e ele queria se antecipar. Nesta época, Gabriela, filha de André, estudava em uma escola particular que, embora devesse receber a vacina pela rede pública, ainda não tinha sido visitada pelo CS. Apenas no ano de 2016, ela passou a estudar na escola que o pai trabalhava, devido às complicações financeiras da família e pelo desinteresse da menina nos 
estudos "ela estava dando trabalho, não estava valorizando, então, já que eu estou aqui, trouxe para cá” (DIÁRIO, 14 de abril de 2016). O fato de André trabalhar na escola, segundo ele, facilitou a vinda das filhas e seu acesso às informações da vacina:

André: Eu estava aqui na coordenação e peguei um treinamento. A gente teve um treinamento com o pessoal do laboratório, da Secretaria de Saúde. Na época o pessoal do laboratório veio e falou sobre a eficácia da vacina, falou o que a vacina prevenia, que são os vários tipos de problemas que o HPV pode trazer. É bom esclarecer isso: essa vacina que é dada por aí ela não cobre cem por cento todas as doenças que o HPV pode trazer, cobre apenas quatro tipos. (...)

Natália: Isso foi determinante pra você vacinar a Gabriela, ter conhecimento, informação?

André: Foi. Foi determinante porque ela mostrou a estatística de câncer do colo do útero, ele é o maior determinante de mortes de mulheres na fase adulta, porque câncer não vem na fase delas, com idade de 11,12, 13 anos. Ele é uma das grandes causas de mortes, depois do câncer de mama. (...). Então, decidi aqui na escola que poderia ajudar com a vacina, a prevenir alguma coisa, então eu como pai e responsável [coordenador] comprei a ideia na hora. Foi estritamente por uma questão de saúde. Até mesmo porque as outras questões a gente tem que trabalhar em casa. (DIÁRIO, 14 de abril de 2016)

Enquanto algumas mães se guiavam pela religião ou pela crença na ciência para decidirem vacinar suas filhas, este pai nos mostrou que as informações que ele recebeu foram essenciais para decidir sobre a vacinação. Quanto à obrigatoriedade da vacinação para os filhos, André foi ao encontro do que foi preconizado pelas mães anteriores, afirmando que era necessário se vacinar:

Eu acho assim, certas coisas você pode escolher, outras coisas você não pode escolher. Eu acho que vacina é uma das que você não pode escolher. Tem que se vacinar. É minha opinião se é uma vacina testada e comprovada para o bem, por que não fazer? (DIÁRIO, 14 de abril de 2016)

Diante desse breve resgate de falas um cenário complexo de representações vacinais se revela. Percebe-se o poder das mães e dos pais em conduzir as escolhas vacinais sobre as filhas e percebe-se também em quais instrumentos eles se apoiam. Religião, valores morais, informações científicas, cada um buscou à sua maneira (re)posicionar o fenômeno vacinal de acordo com seus princípios. É na família onde se pode observar a vigilância dos pais sobre seus filhos, desde a participação em uma campanha de vacina até mesmo ao cumprimento de 
regras, adequação de comportamento, dentre outros fatores. A vigília é exercida pelos próprios pais formando-se por meio de um processo histórico-social, como aponta Foucault:

No momento mesmo em que se encerra a família celular num espaço afetivo denso, investe-se essa família, em nome da doença, de uma racionalidade que a liga a uma tecnologia, a um poder e um saber médico externos. A nova família, a família substancial, a família afetiva e sexual é ao mesmo tempo uma família medicalizada. (2001, p. 317)

A medicalização aparece como um processo dotado de poder, o qual coloca a família como "médico" de seu pequeno corpo social. São as práticas de uma medicina externa agindo por dentro de um minúsculo mundo. No ensaio intitulado $A$ política de saúde do século XVIII (1979), Foucault afirma que a família "não deve ser mais apenas uma teia de relações que se inscrevem em um estatuto social (...), deve-se tornar um meio físico, denso, contínuo que mantenha e favoreça o corpo da criança” (p. 199). O núcleo familiar, como um meio de formação, o primeiro de muitos diriam alguns estudiosos, tem a saúde como um de seus objetivos maiores e obrigatórios. Foi a partir do século XVIII que a família passou a ser alvo do "empreendimento de aculturação médica" (1979, p. 200), cuidando para que o corpo sadio, a higiene, os espaços límpidos e arejados fossem suas premissas. A distribuição de lugares e do tempo, e sem mais, de práticas de inoculação e vacinação eram partícipes desse processo,

A medicalização da sociedade se processava não apenas pela intervenção do médico em determinados lugares e situações, mas pela incorporação dos referenciais médicos na família, na organização das ideias, na forma de se apreender o mundo. (RODRIGUES, 1997)

Nessa perspectiva, as campanhas junto aos grupos sociais, especialmente às famílias, foram priorizadas incidindo de forma decisiva no processo de medicalização da vida em sociedade. A maneira mais fácil do Estado estar no polo do micro controle era começar sua atuação dentro dos lares. A saúde pública foi o caminho no qual o Estado por meio do poder emanado da medicina interveio no seio privado da família brasileira, no sentido de moralizá-la, levando-a aos padrões higiênicos e eugênicos desejáveis (BARBIANI et al, 2014, p. 568). Houve aqui, segundo Barbiani (2014) um duplo deslocamento: o primeiro de encontro a Foucault, quanto à vigilância do corpo social, e o segundo, com a intensificação do discurso do 
aspecto preventivo das doenças. E a vacina está dentre estas duas faces, no cuidado do coletivo e no fato da prevenção.

A família foi invocada para gerir a responsabilidade moral para a criança. À mulher, segundo Rohden (2002), foi requisitada a vocação à maternidade, à reprodução e aos cuidados domésticos, isso inclui o trato da saúde da família.

$\mathrm{Na}$ abordagem à família, cada vez mais requisitada, caberia às mulheres um papel de destaque. A maternidade era evocada ao máximo, sendo as mulheres convocadas à vocação sagrada da maternidade e da família nuclear. (AMMAN, 2003; LEMOS et al., 2010 apud BARBIERI, 2014, p. 67)

Os tradicionais cuidados com a casa e com os filhos passam a ser investidos de outra ordem de poder, delegada e demandada pelo Estado "às mães devotadas, afinal a criança bem-amada será adubo e a semente do adolescente, futuro adulto patriótico". (COSTA, 2004, p.73 apud BARBIERI, 2014, p. 68)

Das intervenções privadas, posteriormente, às famílias foram requeridas obrigações diante do espaço público, do bem coletivo. A prevenção contra doenças apareceu como ato de responsabilidade nos cuidados para com as crianças, especialmente na relação mãe/filho. Se não atendidas essas obrigações, geralmente, às mães eram atribuídas marcas negativas como: irresponsabilidade, falta de amor, de consciência ou de orientação, preguiça ou desleixo.

Isso revela como as mulheres foram e ainda estão mantidas e condicionadas a padrões ideologicamente solidificados, tais como o de cuidadora. Assim, historicamente os valores da pedagogia higienista passaram a mirar às mulheres,

A anunciada mudança de status da mulher se dá em relação ao papel que ela desempenhava na família colonial e ao tratamento social dado à doença e aos doentes daquela época. À parte do discurso sedutor da nova república, na realidade a mulher "mãe de família" foi especialmente "tratada" pelos médicos em sua "vulnerabilidade inata", portadora de fragilidades físicas e emocionais das quais o universo masculino não se ocupava (VIEIRA, 2002; LEMOS et al., 2010). Essa intervenção está devidamente posta sob a responsabilidade do médico e focada à educação das "mãesmestras". (RODRIGUES, 1997 apud BARBINI; JUNGLE, 2014, p. 876)

A Ginecologia e a Obstetrícia, segundo Rohden (2002), foram as áreas responsáveis por legitimar essas ideias, formando "campos de intervenção sobre o corpo da mulher que ultrapassam a preocupação com as doenças femininas" (2002, p. 48), estendendo-se à família. 
Não cabe aqui fazer um apanhado sócio histórico sobre a ideia de maternidade e como ela se consolidou ao longo do tempo, mas mostrar que maternidade é vista como um ato social, por isso mesmo, espera-se dela cumprimento e adequação. Segundo Griscy (1995), o amor materno é uma das faces dessa ideologia em relação à mulher-mãe, pois para ele converge a dimensão santificada atribuída à maternidade.

Assim, ideologicamente, ser mãe não é só gerar, mas também não é só criar, o que torna a mulher-mãe vulnerável à ideologia: sem filhos, está em falta com sua natureza de mulher, uma vez que não cumpriu sua função biológica; com filhos, fica comprometida como exclusiva criadora. (1995, p. 30)

E um dos requisitos dessa criação é o amor, materializado no cuidado. O ideário da "boa mãe" e "bom pai" é estimulado por meio da responsabilização dos pais nos cuidados dos filhos - e sua consequente culpabilização em caso de divergência ou fracasso. "Há normas e condutas para as funções de maternagem ${ }^{59}$ e paternagem ideais, estas necessárias para garantir o adequado desenvolvimento da criança, as quais no geral rondam a figura do pai provedor e da boa mãe, esta que deve seguir os preceitos do amor materno e da mãe higiênica" (BARBEIRE; COUTO, 2015, p. 113), assim, a vacinação tornou-se então, de acordo com as autoras, um dos pilares das orientações da pediatria e da saúde pública, e por que não, da opinião social. Nesse cenário, ser "boa mãe" é ter a carteira vacinal do filho completa, como preconizados pelas mães citadas até aqui. Nota-se que

Essas mães expressam um imaginário de maternagem norteado pelo desejo de apropriação do cuidado parental de forma singularizada, com liberdade e autonomia e, ao mesmo tempo, pela permanência do ideário de "boa mãe", cuja carapaça é assumida ou rejeitada de maneira dinâmica e ambivalente, uma vez que este ideário as protege e as ameaça, simultaneamente. Há, portanto uma relativização da autonomia e da singularização do cuidado parental que, num primeiro momento, nos depoimentos das mães seletivas e não vacinadoras apareciam como inquestionáveis. (BARBIERI; COUTO, 2015, p. 111)

\footnotetext{
59 Enquanto a maternidade é tradicionalmente permeada pela relação consanguínea entre mãe e filho, a maternagem é estabelecida no vínculo afetivo do cuidado e acolhimento ao filho por uma mãe. O modo como se dará esse cuidado, segundo a antropóloga Kitzinger (1978), dependerá dos valores socialmente relacionados ao que é ser mulher e ao significado de um filho em um determinado contexto cultural. Desta forma, espera-se que a valoração e a vivência da maternidade e da maternagem variem historicamente e de acordo com a inserção das mulheres em culturas específicas. (GRADVOLH et al, 2014, p. 56)
} 
A responsabilidade com a vacinação acabou por se estender a todo o contexto familiar, afinal, o referencial de cuidado aqui pode ser entendido como múltiplo de sujeitos:

É orientado por perspectiva reflexiva e crítica que valoriza a dimensão relacional entre os sujeitos, num contexto de intersubjetividade. No âmbito das práticas de saúde, o cuidado faz uma aproximação dialógica entre os êxitos das tecnociências biomédicas com a sabedoria e o sucesso prático dos sujeitos envolvidos, cuja ponte se funda no que move e faz sentido aos indivíduos, às coletividades, seus projetos de felicidade. Nesse estudo, esse conceito foi extrapolado para além do universo das práticas de saúde, ou seja, casais e vacinação infantil, e também norteou as relações de parentalidade ou de cuidado parental. (BARBIERI; COUTO, 2015, p. 108)

A noção de que a família poderia "falhar" em sua tarefa de cuidar, intensificou a culpabilização desta, seja por omissão, ignorância ou descuido, seja pela racionalidade argumentativa dos higienistas. Frente a isso e antes que essa falhasse, "educar" a família foi necessário em prol de torná-la apta e responsável por reproduzir esta educação sobre/de seus membros. Só assim a família lograria garantir o bem-estar de si mesma e coletivo, obter a qualidade de vida, como prega-se abaixo

fornecer alimentação equilibrada, estimular as crianças física e psicologicamente e a gerar vínculos saudáveis. (...) Nesse sentido, os membros da família são aclamados e convocados a serem os agentes da qualidade de vida, recaindo sobre eles o dever pelo "autocuidado", interpretado pela naturalização de práticas de consumo de artefatos bioquímicos, corporais e espirituais cada vez mais diversificados e extensivos a todas as camadas sociais. (BARBIANI et al, 2014, p. 576)

Como um artefato bioquímico, a exigência pela vacina e por uma família educada é interessante para ser deslocada aos dias de hoje frente às instituições estatais. Cartões de vacina em dia para matrícula em escolas são exigidos, vacinas específicas para viajar a alguns países também, até no momento de exercer algumas profissões, em especial as da área de saúde, elas são evocadas. Mesmo para a inserção de cidadãos em programas de governo, as vacinas 
posicionam-se com um requisito. É o que acontece com o Programa Bolsa Família (PBF) ${ }^{60}$, que trago para efeitos de ilustração.

Segundo Carvalho et al (2014), o PBF possui como uma de suas três diretrizes maiores, o reforço ao exercício de direitos sociais básicos nas áreas de Saúde e Educação, por meio do cumprimento das condicionalidades (BRASIL, 2006), o que significa que no setor da saúde, as condicionalidades que as famílias devem cumprir são o acompanhamento do crescimento e desenvolvimento infantil pela vigilância nutricional, a vacinação para crianças menores de sete anos e a assistência pré-natal e pós-parto (BRASIL, 2006). O não cumprimento dessas condicionalidades pode implicar no desligamento das famílias beneficiárias do Programa. Sob responsabilidade do Estado, dos municípios mais especificamente, ficou a oferta dos serviços condicionalizantes, como a oferta das vacinas.

Para os idealizadores do Bolsa Família, a exigência de condicionalidades constituiria uma forma de ampliar o exercício do direito à saúde e à educação, ainda incompletos entre nós. Entretanto, é preciso reconhecer que o alcance de tal objetivo exige a implementação de mecanismos consistentes de acompanhamento social das famílias beneficiárias no sentido de reverter tal exigência em real oportunidade de inserção social. É indiscutível que ações dessa natureza contribuiriam em muito para o sucesso do Programa, a exemplo de outros programas nas áreas de assistência social e saúde que apostam no fortalecimento das relações de vínculo entre profissional e população beneficiária e a inter-relação entre diferentes setores, como os da assistência e da saúde. (SENNA et al, 2007, p. 90)

Mais uma vez, "ao ser exigido o cumprimento de obrigatoriedades como condição para o exercício de um direito social” (Ibid., p. 90), a vacinação em dia torna-se item indispensável para as crianças até os sete anos como condição à sociabilidade e participação no programa. $\mathrm{O}$ que é interessante, como sugerido por Senna et al (2007), é que as condicionalidades exigidas, apesar do Programa optar pelo foco na família, recaem mais uma vez na figura da mãe:

gestante ou nutriz, que por sua vez, estão responsáveis pelas crianças e pelos adolescentes daquela família. Seria como pedir a ela que seja, não uma mulher em

\footnotetext{
${ }^{60}$ Instituído pela Lei n. 10.836, de 9 de janeiro de 2004, o PBF é um programa do governo federal que regula a transferência direta de renda com condicionalidades, que beneficia famílias em situação de pobreza e extrema pobreza (BRASIL, 2006).
} 
situação de exclusão, mas acima de tudo, uma mãe cuidadosa, consigo e com o outro, para ser contemplada pelo programa. (p. 89)

A mulher mantém, agora institucionalmente para o Estado, um papel de cuidadora oficial da família que passa a ser priorizada pela política social. Assim como acontece com o PBF, em outros momentos e áreas do Estado, a mulher e a vacina são novamente chamadas à cena, como na própria campanha do HPV.

Dentro da ótica do cuidado e retornando para o Gama/DF, Silvia, uma das orientadoras da escola, revelou sua postura favorável frente às vacinas, tanto para com seus filhos, como para com as alunas e os alunos. Ela é responsável institucionalmente por zelar pelos valores e atitudes dos alunos e ser uma ponte entre a escola e os pais, por isso era uma figura importante quando disseminava as informações sobre a vacina. Para ela a falta de qualquer vacina já era omissão dos pais, omissão essa entendida como desleixo ou falta de responsabilidade. Em uma entrevista, em sua sala, numa tarde quente de junho, ela me contou:

Silvia: Eu sempre encarei [a vacina] como uma obrigação. Como mãe tá aí uma coisa que eu sempre fui fiel, foi ao cartãozinho, acho que porque o meu pai era, principalmente o meu pai, minha mãe nem tanto, ele achava que vacina era a salvação, que você tomando a vacina você estaria livre de todas as doenças.

Natália: Então você foi bem vacinada?

Silvia: Bem vacinada! Eu aprendi essas coisas com ele.

Natália: E depois você passou pros seus filhos?

Silvia: É, todas as vacinas que tinham disponíveis eu tomava, (...) a gente tomava todas as vacinas, todas as campanhas. Então eu acho que é obrigação, fiz isso com as minhas crianças também.

Natália: E com eles aqui [alunos e alunas]?

Silvia: Eu acho, eu acho que o pai que não vacina o filho é omisso, eu penso assim. É como você ter... Você não tem a obrigação de levar o seu filho pra escola? De acompanhar ele, fazer um acompanhamento de como ele tá indo? A vacina faz parte disso também. (DIÁRIO, 01 de junho de 2016)

Silvia era outra mãe que prezava pelo cartão de vacina completo, que foi vacinada enquanto criança, que presenciou e sentiu esse processo em sua vida familiar, logo, repassou para os filhos. Entretanto, Silvia era diferente de Vera, a mãe que abre a seção, pois para aquela, a cultura de vacinação não foi algo repassado pela família: 
Eu descobri esses dias, conversando lá em casa, quando eu pedi o meu cartão de vacinas, e minha mãe disse "Não, a gente não vacinava vocês!". Olha, eu tenho 42 anos! Aí eu estranhei e perguntei "mas por que não?". Aí ela disse [a mãe de Vera] que tinha uma história de que vacina era uma alta dose da doença, que a pessoa podia passar mal, e como era no interior do Paraná, a gente muito pobre... Isso era uma falta de informação naquela época, né? Tanto que eu descobri que eu não sou vacinada nem para Sarampo, nem aquela... Tétano, Difteria... Eu não tomei nada, nunca, a minha primeira vacina foi quando eu pisei num prego, tinha uns 15 anos, e depois só quando eu engravidei. (DIÁRIO, 10 de maio de 2016)

As falas das duas educadoras eram antagônicas quanto à vacinação em suas infâncias e podem demonstrar que vacinar ou não quando criança não garantia adesão ou contra adesão automáticas às vacinas quando adulto ou quando mães. Entretanto as duas se encontravam plenamente em seus argumentos quando falavam da vacinação de suas filhas e filhos, encaravam a vacina como necessária para a saúde deles e forte representante do cuidado que tinham enquanto mães.

Estas rápidas análises dos dados de pesquisa intensificam o que há pouco discuti sobre as estratégias de ação, no caso a vacina, que interpelam a mulher, a boa mãe. A prática da vacinação e o processo que a envolve, incluindo a atuação dos serviços de saúde, as campanhas de mídia e a experiência apreendida com tal prática, influenciaram a elaboração das representações que as mães têm sobre a vacinação das crianças e, reciprocamente, tais representações vêm orientando sua prática. A maioria das entrevistadas considerou que os pais/responsáveis são comprometidos com a atividade de vacinação dos filhos, qualificando as mães como "cuidadosas" com as datas do calendário vacinal, embora nem sempre saibam o objetivo da vacinação. Tal consideração provavelmente está relacionada à construção da representação "todo mundo sabe que tem que vacinar, porque é uma prevenção" (DIÁRIO, 03 de abril de 2016), como disse Silvia. Estar com a vacinação em dia é demonstrar cuidado. Entretanto, há outra face. Não aceitar certas vacinas também pode querer dizer o mesmo. 


\section{As vacinas dispensáveis e as indispensáveis}

Conheci a mãe que irei retratar agora por meio de uma conversa com a Silvia. Ela se recordou de uma professora que trabalhou na escola e era veementemente contra a vacina do HPV no corpo de sua filha, embora tenha ajudado a escola a vacinar as alunas. O nome dela era Mônica, naquele momento era professora aposentada da secretaria de educação e trabalhou na escola por muitos anos. Mônica foi a única mãe que conheci na pesquisa que se posicionava contra a vacina do HPV.

Apresento-a. Mônica era pernambucana, tinha por volta de 52 anos, era branca, católica, tinha o físico forte, pintava os cabelos de loiro escuro e estava com as unhas feitas. Mônica, como Vera, foi uma criança que não recebeu nenhuma vacina, e justificava isso por ter morado na infância numa cidade do interior de Pernambuco, sem médico, sem posto de saúde. Apenas tomou a primeira vacina depois dos dezoito anos, e fez questão de ressaltar que "não era por negligência da minha mãe, é porque não tinha mesmo", tentando resguardar sua mãe de não ser "boa mãe".

Começou a trabalhar aos 17 anos como professora e só parou quando se aposentou, fato que lhe causava tristeza, pois dizia sentir muita saudade de dar aulas. Foi muito simpática durante a entrevista, a qual realizei em seu apartamento, a convite dela, ao contrário das recomendações que recebi de Silvia, dizendo que ela era muito séria e "meio sem paciência", talvez não aceitaria conversar, ainda mais por se tratar da vacinação da filha. Ela se casou aos 24 anos e sempre teve muita vontade de ter filhos, mas com dificuldade de engravidar, só conseguiu aos 34 anos, "eu esperei dez anos pra engravidar. Foi uma gravidez muito desejada. Foi inseminação in vitro, então teve várias experiências negativas, mas acabou que deu certo. Eles são os primeiros bebês de proveta de Brasília do HUB” (DIÁRIO, 23 de junho de 2016). Ela era mãe de gêmeos, um casal, o Carlos e a Bianca, de 17 anos.

Mônica se descreveu como uma mãe atenciosa que sempre cuidou muito bem da saúde de seus filhos, dando todas as vacinas, e quando não achava alguma delas no centro de saúde, "corria para o Imunocentro", lugar onde ela fez o tratamento de asma e de alergia dos filhos. Um fato que ela me contou durante essa parte da conversa é que desde essa época, ela sempre leu muito sobre os tratamentos e medicamentos que dava para eles, “eu não sou médica e nem enfermeira, mas se vai mexer com os meus filhos, eu tenho que ler detalhadamente para saber 
o que vai acontecer". Este fato lhe conferiu um cuidado diferenciado da maioria das mães contatadas. Ela contou que nunca mais parou de pesquisar sobre saúde. E de fato, foi o que justificou a não vacinação da filha.

Mônica relatou que Bianca estava com onze anos na época da vacinação. A filha estudava em uma escola particular ali mesmo no Gama, mas Mônica ficou mesmo sabendo da vacina porque trabalhava em uma escola pública.

Eu estava acompanhando a vacinação na minha escola quando eu recebi um bilhete da escola particular. E fiquei curiosa no sentido de "Olha, como o governo tá bom, abrangendo até as escolas particulares". Eu estava acostumada a pagar tudo nos laboratórios. Então, eu já estava tão acostumada, que eu pensei que essa vacina do HPV eu teria que comprar. Eu até estava ajudando na vacinação dentro do colégio, tipo ao recolher cartão, arrumar as meninas. Mas aí, quando chegou o bilhetinho, eu fui pesquisar na internet. (DIARIO, 23 de junho de 2016)

É interessante aqui e reforça uma tendência chamada biocomunicabilidade ${ }^{61}$, o crescente uso da internet como fonte de pesquisa nas questões de saúde. Mônica foi pesquisar na rede mundial de computadores "O que o governo estava querendo dar de graça para minha filha, porque quando é de graça eu já desconfio". Contou-me que começou a pesquisar pelos países nos quais a vacina já tinha sido aplicada, depois verificou se existiam avaliações sobre a vacina no Brasil, procurou também sobre a segurança e eficácia desta, isso em sites aleatórios que encontrava no google, em blogs e, principalmente, no facebook.

Pesquisei pra ver se sobre o Brasil já tinha algum dado, e na internet não tinha nada sobre experiências feitas aqui. Então, já foi um ponto negativo para o HPV. Sabe o que eu pensei? Vou pesquisar nos Estados Unidos. O povo sempre faz um parâmetro com eles. Na época que eu pesquisei, os Estados Unidos estava com a vacina suspensa, proibida. Então, quando ela veio para o Brasil, pela primeira vez, ela estava proibida

${ }^{61} E$ e o processo de comunicação de informação sobre saúde e quem está autorizado a avaliá-la, geri-la e pronunciar-se sobre ela (Briggs, 2010; Briggs e Hallin, 2007). Charles Briggs (2010, p. 49) refere-se a diferentes tipos de "cartografias de biocomunicabilidade". A biomédica, que predominaria na organização das práticas das instituições e dos profissionais de saúde, seria unidireccional e caracterizada por um fluxo de informação de sectores especializados detentores do conhecimento para sectores à partida desprovidos dela ou providos de crenças erradas e condutas desadequadas e equivocadas (ver também a este propósito, Fainzang, 2006; Ong et al., 1995). A contrastar com o binómio clássico "autoridade médica/passividade do doente", emergiriam outras cartografias, centradas no "paciente-consumidor ativo" e em debates de cidadãos na esfera pública. À semelhança dos sujeitos de classe média do estudo de Briggs (2010), os quais, diversamente dos de estratos sociais mais baixos, não se identificavam com a cartografia biomédica, por isso acessam novos tipos de informações, em especial, a internet. (CUNHA; DURAND, 2011, p. 221) 
nos Estados Unidos, vi no "face". (...) Aí eu fiquei mais preocupada ainda, pesquisei em vários outros países, na África, na Ásia. Eu saí pesquisando em todos os estados brasileiros, se tinha os prós, se tinha os contras, mas no Brasil eu não achava nada, só achava coisas do tipo “A, que governo bonzinho, ele está vacinando”. Entendi que pela vacina estar proibida nos Estado Unidos, lógico, eles iriam procurar um país rico pra comprar, pra não perder a produção, e o Brasil é um tesouro, aqui a gente compra tudo deles. Aí eu falei “Na minha filha não vai aplicar não". (DIARIO, 23 de junho de 2016)

A consulta à internet reforça o que há muito vem crescendo na atualidade, a existência de um espaço onde novas formas de relações humanas estão se a desenvolver. No caso deste estudo, "consultas" e busca de informações em saúde, mas há expansão em todas as áreas, como relacionamentos, compras, cursos, lazer, mobilização social, dentre outros. Sabe-se que a internet provê acesso imediato a uma grande quantidade de informações, logo, abrindo as mais diversas possibilidades de uso da rede, como problematização, prestação de serviços, debates. No caso de Mônica, ela buscara informações sobre a vacina no Brasil, mas como não achou, tentou coletar informações do exterior, chegando aos grupos anônimos que falavam da vacina.

Kok e Francisco Jr (2012) apontam que esses grupos, também chamados de comunidades virtuais, são novas formas de resgatar um espaço público perdido na história, "com certa informalidade, relações e trocas autênticas, tendo em vista que os constrangimentos existentes na dimensão real não se fazem presentes na dimensão virtual” (p. 291). Cito isso porque Mônica disse ter lido “coisas bem úteis" em um grupo de mães no facebook, contrário à vacina do HPV e que as postagens ali, as quais falavam sobre as reações negativas da vacina nos corpos das filhas, foram um dos itens determinantes pela decisão de não vacinar Bianca. Ela alegou ter lido que em outros países a vacina estava afetando o sistema nervoso das meninas, causando paralisia nas pernas ${ }^{62}$, o que representava para ela expor sua filha a um risco desnecessário. No Relatório de Recomendação da Comissão Nacional de Incorporação de Tecnologias no SUS - CONITEC - $\mathrm{n}^{\circ}$ 82, de 2013, algumas experiências adversas da vacina foram elencadas, tais como "Dor, 81,3\%; Inchaço, 24,2\%; Eritema, 23,6\%; Hematomas, 2,6\% e; Febre 10\%" (p. 23). Nada mais grave foi divulgado no relatório.

Ocorre que a vacina do HPV gerou certo alvoroço na população, como mesmo comentou Raul, o profissional do posto que vacinou as meninas na escola. Ele disse que as

\footnotetext{
${ }^{62}$ Notícia sobre um caso na França em que uma menina teve uma série de problemas de saúde, incapacitantes, e que, por isso, abriu processo contra o laboratório fabricante da vacina Gardasil.
} 
mães e pais iam até ele em busca de informações, e de certa forma, pareciam se sentir seguros depois que ele lhes explicava que não fazia mal algum. Raul atribuiu isso ao fato de portar alguns itens como jaleco e crachá da secretaria de saúde, ou mesmo à camaradagem, devido a ser para alguns "um velho conhecido do centro de saúde". Além disso, para alguns profissionais da comunidade médica ${ }^{63}$, a vacina apresentava considerável controvérsia científica, quanto a suspeita de que não seja totalmente segura à saúde por gerar os efeitos colaterais listados ou não gerar os resultados esperados quanto à proteção do corpo. Sem citar ainda as questões de cunho sócio culturais, como motivos religiosos e estímulo à iniciação precoce da vida sexual.

Apenas como um adendo, frente a estes questionamentos por parte do público, o Ministério da Saúde - MS se fez presente nas redes sociais com o intuito de dirimir essas controvérsias. Como aponta Quevedo e Inácio (2014), essa iniciativa se concretizou na fanpage oficial do órgão no facebook, a qual revela também a tendência da comunicação do Estado com seus cidadãos por meio da rede social, a “comunicação do serviço público prestado por órgãos de governo estão presentes extensivamente na internet. Isto é comprovado na quantidade de perfis oficiais nas redes sociais" (2014, p. 8). Há uma busca por ambientes em que se possa encontrar com facilidade o público com quem se fala. (QUEVEDO; INÁCIO, 2014, p. 9)

Embora a página do MS, segundo os autores listados esteja no "sétimo lugar no ranking de audiência de fanpages governamentais no Brasil, com 1.214.854 de fãs e lá se concentre a pulverização digital da campanha de vacinação do HPV” (2014, p. 4), dentre as mães que conversei, nenhuma sabia da existência dela, nem Mônica, a qual se mostrou tão "conectada". Aliás, boa parte das informações sobre a vacinação do HPV era acessada por meios físicos, como cartazes ou livretos, por meus interlocutores. Exceto Mônica e algumas adolescentes.

Frente a esse cenário de alvoroço e mídias, é interessante, e ao mesmo tempo adventício, comentar sobre o procedimento de judicialização que a vacina do HPV passou no final de 2015. Devido a um grupo de mães que publicaram na rede as graves reações da vacina

\footnotetext{
${ }^{63}$ Notícia publicada pelo site do Jornal Folha de São Paulo em 02/02/2014. Ademais, o documento do Anais de Medicina (2011) informa que não há comprovação sobre a eficácia da vacina do HPV em prevenir o câncer do colo do útero, enquanto os riscos da vacina continuam a ser avaliados. Recomenda que se deveria adotar uma abordagem médica mais rigorosa baseada em evidências para se chegar a uma avaliação balanceada e objetiva sobre os riscos e benefícios dos dois tipos de vacina disponíveis no mercado - a Gardasil e a Cervarix.

${ }^{64}$ A fanpage consiste em uma página identificada, que pode ser criada por qualquer usuário - pessoa ou instituição. Em geral, é direcionada a um conteúdo específico. (QUEVEDO; INÁCIO, 2014, p. 10)
} 
nas filhas, o Ministério Público Federal de Uberlândia-MG pediu a representação destas mães frente ao Poder Judiciário, o qual recebeu a solicitação de suspensão da vacina em todo território brasileiro.

O Ministério Público Federal (MPF) ajuizou ação civil pública pedindo que a Justiça Federal proíba a rede pública de Saúde de aplicar a vacina contra o HPV em todo o território nacional. A ação também pede a nulidade de todos os atos normativos da Agência Nacional de Vigilância Sanitária (Anvisa) que autorizaram a importação, produção, distribuição e comercialização da vacina no país. O fundamento do pedido está no fato de que não foram realizados estudos que comprovem a eficácia ou apontem os efeitos colaterais da vacina, incluída no calendário anual de imunizações da população brasileira há cerca de dois anos. No entanto, para o procurador da República Cléber Eustáquio Neves, autor da ação, "a decisão de fornecer a vacina contra o HPV é temerária, até porque desde que passou a ser aplicada em vários países, mais de dois mil efeitos colaterais foram registrados. O governo japonês, por exemplo, retirou seu apoio para vacinas HPV, em face do relato de inúmeros efeitos colaterais que vão desde de dor, paralisia, alterações do funcionamento do coração, alterações do sistema imunológico, dos sistemas de coagulação do sangue, dos sistemas respiratório, nervoso e digestivo, até dores musculares e infertilidade". Também em Nova Deli, Índia, o Conselho Indiano de Pesquisa Médica pediu a suspensão do programa de vacinação contra o HPV, devido a quatro mortes que estariam associadas à Gardasil, vacina distribuída pelo laboratório Merck no Brasil. Nos Estados Unidos, a Gardasil está associada a $61 \%$ dos casos de reações adversas graves e a $80 \%$ dos casos de invalidez permanente em mulheres com menos de 30 anos de idade. "Tanto que o FDA, órgão que regula a liberação de medicamentos naquele país, viu-se obrigado a convocar uma audiência com as organizações voltadas para a saúde para apresentação de casos", relata o procurador da República. No Brasil, o assunto chamou a atenção do Ministério Público Federal a partir da representação feita pela mãe de uma adolescente, que, após receber a vacina, desenvolveu vários problemas de saúde, com sequelas definitivas". Diante desses fatos, não vimos outra alternativa senão a de ingressar em juízo para impedir que a vacina continue sendo aplicada em todo o território nacional, na rede pública ou privada de saúde", explica Cléber Eustáquio Neves. "Até porque também não existe comprovação cabal de que o HPV cause o câncer de colo de útero". (MPF, 2015)

O processo judicial não teve julgamento até o fechamento deste trabalho. A notícia do MPF não teve repercussão na grande mídia tanto quanto a baixa adesão em 2015 às doses da vacina HPV. Conforme a reportagem de Brasil (2015), houve queda na procura pela vacina em 2015, se comprado a outros anos. Para a autora, que traz a fala da pediatra Isabella Ballalai, presidenta da Sociedade Brasileira de Imunização, esta queda pode estar associada às errôneas interpretações quanto à reação adversa da vacina, especialmente depois de "um grupo 
de 11 adolescentes em São Paulo, no ano passado, ter tomado a vacina na primeira fase de imunização e passado mal” (2015, p. 2). Mas, além disso, ela alerta:

Em outros países, em que a vacinação de adolescentes acontece com sucesso, a vacina vai até o adolescente. Isso [ir aos postos para tomar a vacina] faz diminuir a adesão. A mãe trabalha, o pai trabalha, o adolescente não vai sozinho, sábado é complicado. São vários os motivos da rotina que fazem com que a gente não veja o adolescente indo para um posto de saúde. Vários fatores, somados, fazem com que a gente hoje tenha uma triste realidade, que é uma adesão baixa, de menos de 50\% [na primeira dose] das meninas que gostaríamos de vacinar. (BRASIL, 2015, p. 5)

O grupo de médicos e gestores de saúde procuram na falta de tempo por parte dos pais e no difícil acesso ao mundo adolescente, motivações para a vacina não ter alcançado a meta vacinal em seu público alvo. Ou mesmo culpam o retorno da vacina ao centro de saúde como uma causa de insucesso. Parecem assim, desconsiderar outros fatores da vida que permeiam a não aceitação da vacina, distantes assim da lógica biomédica. Voltando às falas de Mônica, muitos traços contidos nas reportagens acima apareceram nelas. Desde a lógica mercadológica para a compra das vacinas no Brasil até as possíveis reações adversas, emergiram como fatores plausíveis para ela negar a vacina. Em que pese esses motivos, o mais importante foi que a procura de informação específica sobre as vacinas não foi tanto para fundar, por parte dela, a decisão de não vacinar, mas, sobretudo, para ser uma justificativa de tal decisão perante terceiros.

Diante do enumerado como desconfiança sobre a vacina e todas as controvérsias apresentadas, segundo Hochman (2011), não se pode dizer que há no Brasil um movimento antivacinista, tal como nos Estados Unidos, França e Inglaterra,

Do ponto vista comparativo, parece evidente a inexistência de fortes movimentos antivacinistas organizados no Brasil via-à-vis ao mundo anglo-saxão. Existem posições e ações individuais contra vacinas (ou sua obrigatoriedade) fundamentadas por argumentos de natureza religiosa, ética, política ou científica, e mesmo eventuais desconfianças em relação aos riscos de uma determinada vacina, seus custos e benefícios ou do açodamento de uma campanha. No entanto, elas não se transformaram em movimentos sociais, científicos ou profissionais contra a imunização no Brasil como aqueles encontrados nos Estados Unidos ou na Inglaterra do século XXI. (2011, p. 4) 
Porém, em alguns pontos, algumas camadas sociais questionam as vacinas bem como eles o fazem, especialmente no quesito da lógica do mercado de consumo e do poder da indústria farmacêutica. Apontam Barbieri e Couto,

as semelhanças das justificativas parentais pela não vacinação com países de condições socioculturais e epidemiológicas distintas evidenciam dois importantes processos contemporâneos mais amplos (não exclusivos do contexto brasileiro), que se revelaram protagonistas da reflexão acerca da aceitabilidade à vacina para alguns setores sociais de alta renda e escolaridade. O primeiro refere-se ao importante papel da informação veiculada via internet e redes sociais, fenômeno mais amplo que vem modificando as relações entre os sujeitos e os profissionais da saúde. $O$ segundo processo advém de um paradoxo epidemiológico, em que o êxito do PNI, sobretudo em termos de abrangência e efetividade, conduziu a uma situação de controle das doenças imunopreveníveis e, em contrapartida, na maior visibilidade dos efeitos adversos das vacinas. Tal ambiguidade pode ter gerado, em grupos particulares, a sensação de controle epidemiológico das doenças preveníveis por vacina, a concepção de que estas doenças são leves ou benignas e o medo adverso dos imunobiológicos conformando valores opostos de risco e proteção aos que tradicionalmente são vinculados às vacinas pela biomedicina (2015, p. 113).

Para efeitos de comparação, apresento rapidamente a pesquisa de Ana Carolina Barbieri e Márcia Couto. Seu trabalho buscou analisar a dimensão do cuidado parental frente à decisão de vacinar ou não suas filhas e filhos, dentro de um contexto de famílias de alta renda e escolaridade de São Paulo. A pesquisa encontrou três grupos-chave de análise: vacinadores, vacinadores seletivos e não vacinadores. Dentre as especificidades de cada grupo, o estudo apontou para a importância da compreensão sociocultural da (não) aceitabilidade da vacinação no contexto da atenção parental.

Mônica, embora pertencente à camada de classe média e não ao setor de alta renda relatado acima, encontra-se com dois dos argumentos propagados pelo grupo de não vacinadores, estudado por Barbieri e Couto (2015). Em sequência,

A reatogenicidade e segurança das vacinas constituíram outro argumento. Parte dos pais relatou medo dos efeitos adversos graves e efeitos a médio e longo prazos. Dentre eles, os mais temidos são a poliomielite paralítica associada à vacina Sabin, o autismo relacionado à vacina MMR e à associação com doenças autoimunes. 
A crítica ao ganho financeiro e interesse comercial das indústrias farmacêuticas foi apontada por parte dos casais. Alguns referiram que as escolhas sobre as vacinas e os calendários vacinais não são neutras ou embasadas unicamente no benefício à saúde. Acreditam que haja interferência de outra ordem, cujo objetivo é dar lucro às indústrias farmacêuticas. (2015, p. 111)

A título de complementação, as outras premissas das pessoas não adeptas às vacinas, embora não façam parte do que foi levantado por Mônica, complementavam suas ideias. Tais premissas são: 1) noção de que a doença está eliminada/controlada no Brasil ou a doença é leve. Alguns entrevistados por Barbieri e Couto (2015) argumentaram que não há necessidade de vacinar os filhos a partir de um raciocínio de base epidemiológica; 2) crítica à composição e ao mecanismo de ação das vacinas. Alguns entrevistados questionaram os conservantes, adjuvantes e outras substâncias que fazem parte da composição da vacina, sobretudo os metais como alumínio e mercúrio (timerosal); 3) crítica à eficácia e eficiência das vacinas também foi uma justificativa apresentada. Alguns pais defenderam o argumento de que a imunidade gerada pela doença é melhor e mais duradoura do que a da vacina; 4) Crítica ao calendário de vacinação preconizado no Brasil também foi apontado como aspecto importante na tomada de decisão. Alguns pais e mães criticaram, sobretudo, a idade precoce de início da administração das vacinas e o elevado número de vacinas administradas no mesmo momento e; 5)

Há argumentos contextualizadores e que incluíam determinantes sociais do adoecimento como as condições socioeconômicas e estilo de vida como protetores de doenças e preditores de saúde. Alguns pais partiram do pressuposto que muitas das doenças em geral (incluindo as imunopreveníveis) são ocasionadas pelas más condições de saneamento básico e/ou condições alimentares desfavoráveis. Assim consideram que o contexto socioeconômico em que vivem, exemplificado pela boa moradia, amamentação, alimentação adequada, além de outros aspectos como os de ordem afetivo-emocional, confere proteção e qualidade de vida aos filhos e, neste sentido, a vacina passa a ser vista como dispensável. (BARBIERI; COUTO, 2015, p. 17)

São argumentos que se retroalimentam e diferem entre si, mas possuem em sua essência a busca pelo “verdadeiro” cuidado e bem-estar da criança/pessoa.

Não satisfeita apenas com a pesquisa cibernética, Mônica comentou comigo que realizou uma segunda parte da pesquisa, a pesquisa in loco, termo dela. Foi buscar com sua avó e mãe informações sobre adoecimentos por câncer nas mulheres da família. Ela contou: 
Minha avó teve 17 filhos, então foram 7 homens e 10 mulheres, e nenhuma teve câncer de colo do útero e nenhuma teve que tomar essa vacina. Eu fui perguntando para minha avó e para minha mãe quem tinha morrido, do que tinha sido. Teve derrame, coração, mas do colo do útero não teve ninguém, e de câncer só teve uma tia e foi de garganta. Daí foi mais uma confirmação da minha posição. Então a minha filha tem 17 anos hoje, tá saudável, ainda nem entrou na vida sexual, está terminando o segundo grau e eu não tenho medo que ela irá ter câncer do útero porque ela não tomou a vacina. (DIARIO, 23 de junho de 2016)

Parece ser sempre uma busca por ratificar a decisão dela perante a filha, a família, perante todos. E o marido de Mônica, pai de Bianca? Eu não me esqueci dele. Consoante Mônica, ele se mostrou silencioso em relação às decisões sobre a vacinação da filha, "Como sou eu quem cuida disso [saúde], ele deixou que eu decidisse sozinha, sabe que sou cuidadosa”, disse ela. Assim, ela frisou que a decisão de não vacinar Bianca foi estritamente pessoal. A garota, por sua vez, pareceu não interferir na vontade da mãe também, aceitando ficar sem a vacina e, nas palavras de Mônica, isso se justificou pelo medo da agulha "Uma criança de onze anos não manifesta tanto desejo de querer ser furada, né? Então ela não achou ruim não”.

Mônica resumiu o silêncio da filha apenas pelo medo da agulhada, desconsiderando que a menina pudesse ter outros questionamentos sobre proteção/imunidade ou mesmo sobre sexo, que foram abafados pelo jeito de ser da mãe. De todo modo, Mônica não deixou de ressaltar que nos dias atuais, já com dezessetes anos, era Bianca quem fazia as pesquisas na internet, consultava o google quando tinha dívidas, se informava a maneira da mãe, "Ela também é muito pesquisadora, hoje em dia eu acho que ela pesquisa mais do que eu. Ela entra em portal, baixa aplicativo, faz um monte de coisas” (DIARIO, 23 de junho de 2016).

Quando perguntei a Mônica, agora não mais como mãe e sim como professora como foi receber a vacinação na escola, ela disse ter tido a impressão que o processo foi um tanto bagunçado.

Tem mãe que deu uma dose e a criança mudou de escola, deu duas vezes a primeira $\operatorname{dose}^{65}$, se esqueceu de tomar a terceira dose. Então, essa vacina não teve nenhum

\footnotetext{
${ }^{65}$ Relembro que a vacina HPV à época era aplicada em três doses. Como Raul, o técnico de enfermagem me contou, cada dose é a mesma vacina, entretanto, para surtir o efeito desejado da proteção, tem que tomar dentro dos prazos estabelecidos (inicial, 6 meses e 5 anos). Era sobre os prazos temporais que Mônica se referiu acima.
} 
controle. Você acha que as mães no dia de hoje, que trabalham, vão estar ligadas a isso? Sem contar com a quantidade de cartão que se perdeu, que as crianças perderam porque guardavam de qualquer jeito e depois as mães iam na escola reclamar. Porque se fosse pra vacinar como era para ser, elas iriam pra o posto, para o pai e a mãe irem até lá. (DIARIO, 23 de junho de 2016)

Colocando em cheque o sucesso da vacina dentro da escola, afinal, para ela uma vacina ideal era a que acontece no centro de saúde - com a devida organização das doses e cartões, para Mônica a vacina foi levada às escolas por motivos econômicos, "é mais uma maneira de aplicar as doses que foram compradas no exterior, para não as perder", e completou "a compra foi muito grande e para não jogar num rio, distribuíram todas elas para as escolas. Foi pra despachar a compra. Foi por isso que ela abrangeu até as escolas particulares, que poderiam pagar” (DIÁRIO, 23 de junho de 2016). Comentou que foi muito questionada na escola por não querer vacinar sua filha, mas se mostrou firme e não abriu mão de sua opinião, aproveitava mesmo para avisar as mães sobre os riscos da vacinação. Arrisco dizer que, no caso de Mônica, ela se predispunha a contestar as vacinas dentro da escola por ser mais esclarecida ou por possuir informações diferentes, tidas como novas, as quais lhe retirava do status da "mãe ignorante", que constantemente era dado a todas às mães que negavam a vacina, mas agora por motivos religiosos. Mônica se colocava como "científica”, pois possuía dados empíricos.

Por fim, como sua contribuição mais marcante e que dá nome a esta seção, é a divisão que ela fez do mundo vacinal em duas categorias, as vacinas dispensáveis e as indispensáveis:

Tem umas vacinas que não podem deixar de dar, por exemplo, a de Poliomelite, porque você sabe que ela vai fazer efeito, a da gripe também. Os meus filhos tomam vacinas de gripe desde que eram bebezinhos. Aquelas que são as indispensáveis são as que causam reações menores, que agride menos o organismo, digamos assim, tal como a vacina da gripe, afinal todo ano ela é modificada, mas ela é modificada lentamente, ela não causa nenhum problema neurológico. Eu nunca vi ninguém ficar paraplégico porque tomou a vacina da gripe, entendeu? As dispensáveis são tipo a do HPV, porque há um risco em tomar. (DIARIO, 23 de junho de 2016)

Vacinas dispensáveis e indispensáveis. Parecem ser a motivação de todo seu pensamento e ação. São opostas e divididas em graus de reações, risco, agressão ao organismo e modernidade científica. Nesses parâmetros, para Mônica, a vacina do HPV estaria do lado 
das dispensáveis, por trazer riscos, ser agressiva ao corpo e poder dar reação. Embora não tenha elencado outras vacinas nesta sua classificação, ela se mostrou uma mãe que prefere uma imunização personalizada, encaixando-se no grupo dos vacinadores seletivos.

Nesta pesquisa encontramos dois perfis de mães e pais: (1) as vacinadoras, que imunizaram seus filhos e filhas conforme as recomendações do PNI; (2) e as vacinadoras seletivas, que escolheram algumas vacinas dentre as disponíveis, ou melhor, que aplicaram as categorias "dispensáveis e indispensáveis" a elas. Esta divisão foi sugerida por Barbieri e Couto (2015), porém diferente da proposta delas, há um terceiro grupo, que seria das mães não vacinadoras, aquelas que não vacinam seus filhos em hipótese alguma, muito baseado nas premissas “antivacinistas" apresentadas anteriormente. Porém, em minha pesquisa, não conheci nenhum representante desse grupo.

No primeiro caso, as mães e pais vacinadores, percebem no ato de vacinar os filhos uma responsabilidade parental. Logo, sentem-se confortáveis e expressam claro sentimento de dever cumprido. São vistos como "boas-mães" e "bons-pais" na ótica biomédica e no caso do HPV, para a escola idem, pois cumprem o que é prescrito.

$\mathrm{Na}$ segunda situação, para a mãe vacinadora seletiva predominou a concepção que vacinação é uma proteção importante. Entretanto, o cuidado parental nesta situação esteve associado à busca pela singularização da vacinação, conforme as particularidades da saúde da criança, de seu contexto familiar, posicionamentos morais, dentre outros. Como Bianca nasceu asmática, teve que se submeter a longos tratamentos de saúde, e para Mônica, a filha precisava de cuidados especiais, o que inclui (e exclui) tipos de vacina. Aderir a alguns tipos de vacinação é "assumir significados de risco e ameaça à saúde do filho" (BARBIERI; COUTO, 2015, p. 109).

Segundo as autoras, as mães e pais que compõem esse grupo seletivo vêm de uma classe média a alta, vêm das cidades, são escolarizados e possuem curso superior. Eles encampam um universo simbólico preconizado por Velho (1987 apud BARBIERI; COUTO, 2015), como aquele 
que propõe uma compreensão antropológica sobre a família no contexto das sociedades complexas contemporâneas. Para este autor, a valorização da individualização e a pluralidade de estímulos característicos da sociedade contemporânea sinergicamente contribuem para o surgimento de um campo de possibilidades situado espacial, temporal e culturalmente pelo qual serão cruzados/percorridos diversas trajetórias e projetos individuais/grupais. Sociologicamente, Velho ressalta que é sobretudo no universo das camadas médias urbanas intelectualizadas e "psicologizadas", mais expostas às ideologias de modernização, que se intensificam a valorização do indivíduo, visto como significativo, único e protagonista de escolhas e projetos. Dá-se, assim, importância à autonomia dos sujeitos, à igualdade e liberdade de escolha, à singularidade e à busca de sentido ao indivíduo. (2015, p. 110)

É aqui que se observam os discursos "e práticas de crítica e inovação, e aparece com maior vigor a apreciação da trajetória de vida, da biografia e da experiência pessoal" (BARBIERI e COUTO, 2015, p. 110). Isso corrobora para o reconhecimento por parte de pais e mães que as decisões e escolhas sobre os cuidados ao filho, incluindo a não vacinação devem ser protagonizadas no âmbito do privado e não alvo da intervenção externa seja ela biomédica ou governamental. Ao encontro desta ideia, os autores Cunha e Durand (2011), organizaram um livro que problematiza e perpassa diversos recortes sobre as vacinas, em destaque o recorte do "empowerment individual, o qual evidencia que as pessoas estão mostrando-se mais inclinadas a adquirir conhecimento que as possibilite decidir por si próprias sobre questões de saúde relativas ao seu corpo, o que incluí a vacinação" (CASTRO, 2013, p. 233).

Em vez de um anacronismo voltado à extinção, eles são uma das expressões de tendências sociais emergentes, entre as quais as que dizem respeito às relações da sociedade com as tutelas periciais e o Estado. Lado a lado com estas relações, estão pesando nas escolhas as noções de imunidade personalizada ou de imunização personalizada, isto é, em função da biografia de saúde e das características pessoais. (CUNHA; DURAND, 2011, p. 197)

Retomando Barbieri e Couto (2015), a cobertura vacinal no contexto brasileiro varia segundo a região e o nível socioeconômico das famílias. Em 2007, um estudo por inquérito domiciliar nacional evidenciou que crianças pertencentes às famílias de maior nível socioeco- 
nômico e escolaridade apresentaram as menores taxas de cobertura vacinal em 10 das 27 capitais do Brasil:

Assim, em contraponto aos avanços em saúde atribuídos à vacinação e sua legitimidade pela população mais ampla, alguns pais de alta renda e escolaridade em centros urbanos estão optando por não vacinarem seus filhos, problematizando esta intervenção como uma premissa do cuidado parental. Essas evidências sugerem uma mudança paradigmática no tocante à adesão à vacinação infantil: a transformação da esfera da acessibilidade aos serviços de saúde para o âmbito da aceitabilidade à vacina. (BARBIERI; COUTO, 2015, p. 233)

Termo cunhado por Moulin (2003) a "aceitabilidade" veio substituir o termo "resistência" dentro do fenômeno vacinal,

Uma das consequências dessa análise antropológica moderna foi o abandono do conceito de resistência na avaliação das campanhas de imunização, substituindo-o pelo de aceitabilidade. Em vez de considerar a resistência como um fenômeno puramente negativo, prevaleceu a ideia de analisar as representações e as práticas das comunidades, admitindo que essas possam ser fundamentadas e que reflitam experiências dignas de atenção. (2003, p. 505)

Barbieri e Couto (2015) contemplam esta ideia ao explanar que, para além de tentar explicar a rejeição à vacina, o fenômeno da "aceitabilidade" traz à tona questões sócio antropológicas, visto que

As campanhas de vacinação implementadas em circunstâncias extraordinárias e/ou a administração de novas vacinas apenas são tidas em conta enquanto susceptíveis de se repercutirem na maneira como as pessoas se relacionam com a vacinação comum, ou seja, a vacinação rotineira. Pelo termo aceitabilidade nos vinculamo a uma perspectiva que considera a aceitação e não aceitação como duas faces de um mesmo fenômeno, requerendo por conseguinte uma análise que se ajuste a ambas de forma coerente. Vacinação e não vacinação não são aqui consideradas, assim, como dois fenômenos singulares e independentes a se analisar separadamente (2015, p. 198).

Nestes termos, a compreensão das concepções acerca da vacinação dos filhos será norteada pela perspectiva do cuidado parental, quanto uma perspectiva que valoriza a intersubjetividade dos filhos e também dos pais. No universo das práticas de saúde, a categoria do cuidado tende a aproximar a história de êxitos das vacinas com as práticas das pessoas em 
relação a mesma, fundado no que faz sentido aos indivíduos, às coletividades, seus projetos de vida (Ibid., 2015).

Diferentemente do que as autoras acima discorrem sobre a prática da vacinação nas camadas altas, as quais sofrem fortes interpelações de diferentes tipos, estilos e posturas de vida, pode-se arriscar dizer que nas camadas populares, para um grande número de pessoas, há uma adesão aos processos de vacinação sem muitos questionamentos, pois

se de fato a vacinação está radicada nas relações de poder e autoridade entre o Estado, a ciência e os cidadãos (Moulin, 1996; 2007), (...) os utilizadores sobre os quais o poder médico e a ação disciplinar se exercem mais intensamente e autoritariamente são aqueles com menor capital escolar e económico e, em geral, posicionados de maneira mais desfavorável na estrutura de classes. São estes que exprimem uma aceitação mais passiva da norma e daqueles que a administram. É certo que a face plana do consenso recobre uma multiplicidade de matizes, sentidos e motivações, irregularidades, conveniências e prioridades pessoais (CUNHA; DURAND, 2011, p. 226).

Percebe-se assim que só pesar riscos e benefícios frente ao complexo emaranhado vacinal favorece um quadro insuficiente das dimensões implicadas nas relações atuais com a vacinação. Compreender ou ao menos conhecer o que está imerso nas perspectivas culturais e nas experiências individuais é necessário. Nesse sentido, com intuito de enriquecer a análise e, propositalmente guardado para este momento, passo a uma seção sobre os diferentes temas, por vezes ocultos, que mais perpassaram as conversas e decisões sobre a vacinação do HPV - o medo da precocidade da vida sexual e os valores religiosos e morais.

\section{Os protagonistas empíricos do cuidado: a religião e o sexo}

A vacina HPV foi associada por algumas pessoas ao sexo e à religião. Para apresentar esse assunto, esbocei três recortes - quando e como se fala de sexo, (explicitação); quando e como não se deve falar dele (repressão ou silenciamentos); e os reflexos dos preceitos religiosos e morais (regularização ou moralização). Tomei emprestada essa divisão teórica de 
Diniz (2014), autora que também pesquisou em escolas públicas do DF acerca da construção da sexualidade em crianças.

No âmbito do sexo, como este vírus é transmitido via sexual e a imunização traz à tona este tema, a sexualidade passou a ser objeto de diálogo. Quanto à religião, a qual o sexo aparece por trás de seus argumentos, a resistência veio especialmente de grupos católicos e evangélicos, pois “Ao defender a castidade como única 'vacina' 100\% eficaz contra doenças sexualmente transmissíveis, os fiéis propõem, através das redes sociais na internet, o boicote à vacinação" (BARROS, 2014). Para ilustrar ambos os posicionamentos ${ }^{66}$, Mônica, a mãe do não à vacina $\mathrm{HPV}$, expôs seu posicionamento e justificou que não seria por medo do contágio do vírus pelo sexo que sua filha estaria em perigo, afinal, ela tinha uma religião.

Olha, Natália, a minha filha é católica. Então, eu acho que com 11 anos, ela não estava nem pensando em ter relações sexuais com ninguém, ela é muito tranquila. O que eu passo pra minha filha, independente do HPV, é a valorização dela e do corpo dela e, se ela chegar a se relacionar com alguém, ela tem que pensar nela em primeiro lugar, se prevenir. Eu penso que não adianta prevenir desse vírus aí e deixar a AIDS e um monte de outras doenças transmissíveis de lado, porque a menina acha que está prevenida e acaba se prejudicando muito mais. (DIARIO, 23 de junho de 2016)

A associação da vacina à vida sexual foi retórica constante em sala de aula quando a coordenadora Fernanda entrava em sala para avisar da vacinação - a qual no capítulo anterior pretendia cercear as perguntas dos alunos apenas falando do vírus e do câncer. Para desestabilizar a situação, uma aluna disse: "Professora, a minha mãe disse que essa vacina é só pra quem tem relações sexuais e que se eu tomar essa vacina eu sou uma prostituta”. Fernanda reagiu na hora tentando explicar por termos científicos que aquela informação não tinha consistência, ao dizer "Olha, o câncer do colo do útero pode dar até mesmo se você não tiver nenhuma relação sexual na vida". Mas segundo ela, o "estrago" já havia sido feito, pois a menina fez o comentário para toda a sala, o que gerou inúmeros comentários e risos. Ainda com Fernanda, mas em outro momento, pergunto por que uma das meninas que havia na lista não pôde tomar a vacina, e ela disse que "A mãe dela não deixa ela tomar e acha que a filha [de onze anos] vai começar a transar" (DIÁRIO, 03 de junho de 2015).

\footnotetext{
${ }^{66}$ Nota-se que os dois temas se imiscuem a todo tempo e não há como traçar uma linha divisória para apresentálos separados, por isso, quando necessário, farei uma nota sobre cada um.
} 
Numa conversa com Silvia, a orientadora educacional da escola, também ouvi o seguinte: "Uma das professoras está notando um comportamento diferente na Ana [umas das alunas do sexto ano], ela acha que depois que a menina tomou a tal vacina, 'está se achando". No mesmo instante perguntei por que ela achava que a professora tinha dito aquilo. Ela explicou que "a menina ficou mais vaidosa, virou moça, tinha despertado algo, pareceu que a vacina tinha 'estimulado’ nela a sexualidade antes da hora” (DIÁRIO, 21 de março de 2016). Mas não me dei por contente até perguntar pontualmente à Silvia "Por que a idade da campanha é de 9 a 13 anos?". E ouvi "É porque as meninas estão começando a vida sexual cedo, tipo com uns dez anos, acho que eles quiseram fazer uma margem de idade”.

Cleide, uma enfermeira que conheci na escola, apontou que "Muitos pais se recusaram [a vacinar] porque o HPV somente se pega pelo ato sexual, então eles não autorizaram as filhas a tomarem, não conseguiram entender que é uma questão de prevenção, não é que a filha tá tendo relações sexuais ou vai ter" (DIÁRIO, 03 de junho de 2016). Para esta profissional da saúde a vacina é algo preventivo e não retroativo ao sexo. Ela ainda considerava que para muitos pais havia um medo em descobrir que a filha não pudesse mais tomar a vacina, devido a não ser mais virgem.

Segundo Diniz (2014), um dos maiores receios de alguns pais e mães era encarar ou antecipar uma conversa sobre sexualidade que, por vezes, não estavam prontos para ter. Neste caso, este receio também existia, o que seria despertado a partir da vacina, pois eles seriam compelidos a explicar às filhas o que elas estavam tomando e o porquê. Percebe-se que o medo e o preconceito rondaram a vacina HPV.

Conheci uma mãe e uma avó numa reunião de pais do colégio no fim do segundo bimestre letivo. Uma delas foi Marizete, 45 anos, recém-casada, com o ensino fundamental completo, da Igreja Batista. Possuía uma única filha, Beatriz, de treze anos. Em nossa conversa sobre a vacinação de sua filha, Marizete me contou que a menina tomou todas as vacinas na escola e que ela, enquanto mãe, se sentia satisfeita em relação a isso, pois sabia que a filha estava protegida. Quando perguntei a ela se as duas conversaram sobre sexualidade e vacina, ela confirmou e disse que, de maneira alguma, se preocupou sobre a vacina ser uma "porta" para a vida sexual de Beatriz, visto que algumas pessoas pensavam assim. Ela relatou que é bem clara com a filha sobre isso (sexo), e não faz questão de esconder nada, entretanto, só fala sobre o tema quando a garota pergunta (DIÁRIO, 20 de agosto de 2016). 
Vê-se que o conceito "boa-mãe" está a todo tempo no ar. A segunda mulher era uma avó-mãe, Dona Maria, de 62 anos, casada, mãe de cinco filhos, no momento desempregada. A avó de Jéssica cuidava da menina desde pequena quando sua filha de quinze anos engravidou. Confessou que mesmo depois de a neta ter tomado as vacinas do HPV, os assuntos sobre sexualidade eram "controlados". Dona Maria ainda comentou coisas como: "Eu nunca cheguei a entrar no assunto, assim, diretamente, mas já comecei a falar algumas coisas pra ela, porque a gente tem que ir ensinando. Mas, sabe, nunca cheguei assim, direto ao ponto, porque também ela só tem 12 anos, né?” (DIÁRIO, 20 de agosto de 2016). Alegando a falta de curiosidade da neta, ela ainda dizia estar confortável para falar pouco sobre sexo, pois era um assunto para mais tarde: "Conforme ela for perguntando eu vou contando. Eu falo para ela que isso aí [sexo] é pra mais tarde. Lá na frente, quando você casar, for mãe”. Marizete e Maria explicavam sobre o tema sexo conforme a demanda, de acordo como eram interpeladas a falar disso para a filha ou neta.

Falar sobre sexo ainda apresenta resistências. Seja dentro de uma escola ou em casa, seja na aula sobre sistema reprodutor para explicar sobre transmissibilidade de uma doença por meio do sexo como o HPV, seja em casa ou no momento de um questionamento, de uma curiosidade espontânea. Estas falas são muito expressivas e revelam como as mães estão tratando o tema com as filhas. Elas não deixam de ter com a filha sobre sexo, mas dentro dos moldes morais, valorativos, religiosos, sempre nos termos apropriados e nos momentos estratégicos por parte de quem fosse responsável.

Ao longo do tempo, de acordo com Elias (1993), um dos efeitos do processo civilizador, que se caracteriza em "uma mudança na conduta e sentimentos humanos rumo a uma direção muito específica” (p. 193), é o sentimento da vergonha. Educar é cuidar-se do pudor. É conter manifestações do corpo que podem causar repugnância e vergonha, para si e para os outros, como defecar, peidar, escarrar, pigarrear, ficar excitado, masturbar-se, praticar sexo, ficar nu, tomar banho. O nível de um indivíduo educado está para a sua sensação de embaraço e de vergonha. A educação, iniciada na família e continuada na escola, implica o recato com a sua intimidade corporal, "o enclausuramento da vida íntima, seja por meio do recolhimento ao dormir, seja pela necessidade de banhar-se, transformou suas privações uma das maiores mudanças no comportamento humano a partir do século XVI” (1993, p. 194). O recato e a vergonha ao afetar em diversos sentidos a vida, o sexo não deixaria escapar, 
passando a ser "cada vez mais transferido para trás da cena da vida social e isolado em um enclave particular, a família nuclear" (ibid., p. 180). E dentro desta família, o sexo foi também isolado da criança. Era ela o ser puro da família.

Guardadas as ressalvas da época analisada por Elias, as mudanças históricas e sociais que ocorreram desde lá, pensadores como Freud (1997) avançaram com o tema da sexualidade de maneira profunda e revolucionária, em especial no universo infantil. Ele foi responsável por desenvolver perspectivas teóricas acerca da sexualidade infantil que evidenciaram como e em que a sexualidade se manifestava nas crianças. Crianças possuem sexualidade e esta forte realidade assustou quando foi revelada.

A manifestação da sexualidade nas crianças, de acordo com Freud (1997), vem acompanhada da curiosidade que o sexo proporciona. As crianças buscam saber sobre sexualidade a partir das experiências corporais, essa parece ser a principal noção que Freud transmite através de sua teoria da sexualidade. (DINIZ, 2014, p. 130)

Frente ao que Freud evidenciou e o que muitos outros autores ainda falariam no século XX sobre a sexualidade humana, "isto não fez com que a ideia puritana de que crianças deveriam ser resguardadas de várias informações sobre sexo fosse superada” (Ibid., p. 131). O que se observa ainda hoje é um cuidado velado ao falar de sexo, de deixar a sexualidade aflorar. Dentre uma das formas de controle e medicalização realizadas pela família, está o controle da sexualidade,

A sexualidade é o nome que se pode dar a um dispositivo histórico: não à realidade subterrânea que se aprende com dificuldade, mas à grande rede de superfície em que a estimulação dos corpos, a intensificação dos prazeres, a incitação ao discurso, a formação dos conhecimentos, o reforço dos controles e das resistências, encadeiam-se uns aos outros, segundo algumas grandes estratégias de saber e poder (FOUCAULT, 1984, p 85).

Como falar/regular essas informações sobre sexo sem ter que evocar a vergonha ou ser invasivo? Segundo Diniz (2014), o próprio Foucault nos ilumina a resposta por meio da ideia da "polícia do sexo": 
O autor explica que polícia do sexo é a "necessidade de regular o sexo por meio de discursos úteis e públicos e não pelo rigor de uma proibição" (1988, p. 28). Ele apresenta exemplos em seu texto que evidenciam que a ciência e as moralidades trabalham juntas quando se pretende regular o sexo. Não será dito para a criança que o sexo não existe, no entanto, a sua existência será regulada e controlada nos corpos púberes, ainda que infantis, dessas crianças através do conhecimento científico (DINIZ, 2014, p. 129).

Falar-se-á de sexo, mas nos termos científicos. O dispositivo da sexualidade vai operar dentro "de um conjunto heterogêneo que engloba discursos, instituições, organizações arquitetônicas, decisões regulamentares, leis, medidas administrativas (...) em suma, o dito e o não dito são elementos do dispositivo" (Ibid, p.57). A célula familiar permitiu que "em suas duas dimensões principais - o eixo marido-mulher e o eixo pais-filhos - se desenvolvessem os principais elementos do dispositivo da sexualidade" (Ibid, p. 119). Diniz (2014) alerta que Foucault (1997) explicita que recorrer à ciência para falar sobre sexo do ponto de vista purificado e neutro evidencia algo de significativo. Além de resguardar as pessoas de reverberações falsas, falar de sexo cientificamente manifesta uma pretensão ilusória em não se vincular a uma perspectiva moral específica.

As mães e pai que conheci, a escola visitada, praticamente todos e somente quando necessário, costumavam tocar no assunto do sexo dentro de termos científicos com os filhos ou alunos. Falar de sexualidade dentro da ótica da ciência é falar dele com fins à reprodução ou prevenção de doenças, "nunca sobre prazer, alegando ser essa uma experiência da vida adulta. A sexualidade é usualmente apresentada em estreita articulação com a família e a reprodução" (LOURO, 2010, p. 48). Estado, escola e família se encontram na ideia de um "sexo bem educado" e conforme a pedagoga Maria Rita de Assis César (2004), atingiu padrões de controles "higiênicos e morais, segundo a nomenclatura do 'sexo responsável', do 'sexo saudável' e do 'sexo seguro'. À primeira vista, a ênfase na saúde, na responsabilidade e no binômio risco/segurança vem produzindo uma educação sexual definida pela singela ideia do 'bem viver”' (CÉSAR, 2009, p. 39). De volta ao Gama, Mônica, a mãe de Bianca, deixou isso bem claro quando explica:

$\mathrm{Na}$ época da vacina, as colegas dela diziam que tomando a vacina já podia beijar na boca, já podia ficar com os meninos, isso na sétima e na oitava. Aí eu fui dizer pra ela que a vacina não estava autorizando a ela ficar com ninguém, que a vacina é uma 
prevenção pra vida inteira. Sabe, ela quis namorar com quinze anos, mas isso era só coisa de menina de quinze anos, porque menina de quinze anos gosta é de se apaixonar. E agora ela tá só nos estudos, tá sem namorado, tá só estudando porque quer passar em Direito. Se ela agora arrumar um namorado ela já vai estar com dezessete, vai ter outra cabeça, né? Vai se apaixonar sim, mas vai se apaixonar lento, com quinze anos um beijo estremece a terra inteira, então com 18 anos é diferente. (DIÁRIO, 23 de junho de 2016).

Recorrendo aos termos científicos "a vacina não estava autorizando a ela ficar com ninguém, ela é uma prevenção", Mônica parecia se atrapalhar diante da sexualidade de sua filha, inibindo-a em seus relacionamentos com vista a um suposto controle do corpo e dos sentimentos. Por sua vez, ela gostava muito da categoria "lentidão". Associava isso claramente ao descrever a filha como tranquila - para tudo ela frisava que Bianca era tranquila. Achava que se a filha passasse por cada experiência da vida de modo lento, encontrar-se-ia com um "bem maior" segundo ela ou o "bem viver" como diria César (2009). No que diz respeito à sexualidade, Louro (2000) lembra de que se trata de um assunto sobre o qual as crianças e os jovens têm uma especial curiosidade e interesse, sendo esse um tema que ocupa suas conversas. "As perguntas são constantes, impulsionadas pela curiosidade e pelas emoções diante de seus corpos púberes em mudança e das mudanças de olhares dos outros sobre si” (DINIZ, 2014, p. 133). Seja na escola, em casa ou nas ruas da cidade, as crianças aprendem cotidianamente sobre sexualidade. As escolas buscam estratégias para falarem do assunto, mas sem ultrapassar a autoridade familiar, "pois são eles que determinam, no ambiente privado de suas casas, o que as crianças podem ou não saber sobre sexo” (DINIZ, 2014, p. 134). Assim, sexo “não se julga apenas, administra-se também”. (FOUCAULT, 1988, p. 93). E quando ultrapassam podem sofrer reverberações como as de Luana, aquela professora da escola que questionou a palestra sobre sexo dada na escola para sua filha. Há que se buscar um equilíbrio entre família e escola:

É imprescindível o conhecimento pelos responsáveis dos trabalhos relacionados à sexualidade, principalmente pelo fato de se tratar de um assunto que provoca resistências de muitas pessoas. No entanto, os professores não devem temer as ameaças e as proibições que eventualmente possam ser feitas por responsáveis pelas crianças, pois a sexualidade é um tema que faz parte de nosso currículo, sendo inclusive recomendado por documentos oficiais de educação, como os Parâmetros Curriculares Nacionais - PCN. (MAIA et al, 2011, p. 40) 
Existem sim os pais que não tocam no assunto, seja por não ter jeito de falar, pela vergonha, por motivos religiosos, ou mesmo, porque sabem que uma hora ou outra os filhos aprenderam algo sobre isso na escola ou na rua. Essa é a visão de Inês, outra orientadora escolar. Um dos fatos que ela me relatou e chamou bastante atenção foi ao relacionar à falta de informação sobre sexo com a situação econômica das famílias, "Há uma falta de oportunidade [de diálogo], como os pais e mães precisam trabalhar e, muitas vezes, ainda estudam, eles não têm mais tempo para os filhos, não orientam, a vida é ali [sozinhos]" (DIÁRIO, 21 de março de 2016). Relatando que há muita oferta [de sexo] na internet e nas conversas com os amigos e, concomitantemente, falta de controle por parte dos pais, muitas vezes devido às longas jornadas de trabalho, meninas e meninos acabando vendo o que querem na televisão. Portanto, Inês afirmava "São valores que os filhos, as famílias, não têm. Uma proteção, um olhar. Não há a companhia dos pais, não há conversa". Como educadora e por sentir essa lacuna, Inês se sentia apta para falar de sexo quando alunas e alunos lhe procuravam para conversar, já que seu papel era oficialmente o de "orientar".

Por falar em acesso a informações sobre sexo dentro de casa, notei em uma conversa com três garotas do nono ano - idade por volta de 15 anos, duas são evangélicas e uma católica - as quais as mães assumiam diferentes tipos de comportamentos e posturas para falar sobre isso, parecendo a "moral" variar de lar para lar. As meninas descreveram muito bem os estilos das mães nesta conversa divertida:

Helena: A minha mãe é doida, digo isso porque desde pequenininha, a minha mãe já me explicava tudo. Ela dizia "se quiser fazer isso [sexo], faça, mas fica esperta".

Flávia: Minha mãe não fala nada, lá em casa, por exemplo, a minha mãe não fala nenhum tipo de palavrão, ela nunca levou namorado lá... Lá em casa a gente não tem esse tipo de liberdade da Helena. A gente nunca fala de assuntos que, vamos dizer, são imorais.

Helena: A minha família é mais aberta, quando eu saio, vou para a rua, minha mãe fala "Helena, cuidado! Se você der seu periquito eu vou costurar com linha de náilon".

Flávia: Aí se eu falasse isso lá em casa!

Helena: E ela fala isso quando está cheio de gente lá em casa. Eu fico "Meu Deus do céu pra quê tudo isso?!". Mas a minha família é toda assim.

Patrícia: Teve um dia que eu fui à casa da Helena e na hora que a gente ia sair, a mãe dela falou assim "vocês não vão dar a periquita não, né?”. [risos] 
Helena: Teve uma vez que a gente estava mexendo no celular e ela falou "vocês não estão vendo foto de pinto não, né?". Sempre que eu estou vendo fotos de menino sem camisa a minha mãe fala "passa pra mim que eu quero ver também".

Natália: Mas e aí, o que vocês acham?

Flávia: Da mãe da Helena? Eu acho super bacana.

Patrícia: Eu acho que ela tá certa.

Flávia: Eu acho que se a minha mãe deixasse eu seria mais rebelde. Na verdade, cada um tem um jeito, por exemplo, a minha mãe é fechada assim porque é o jeito dela...

Patrícia: A minha também é fechada. A minha mãe fala comigo, mas só no momento certo.

Helena: Já a minha mãe s-o-l-e-t-r-a. (DIÁRIO, 04 de julho de 2016)

Falar sobre sexo diretamente - isto é, dizer como ele acontece de fato - dá lugar a falar bastante sobre sexo, algo muito bem marcado por Diniz (2014). Os constrangimentos sentidos por algumas delas refletem que podem estar diante de um assunto "perigoso", assunto que pode ser imoral, como disse Flávia, ou "poluente” no sentido de Mary Douglas (1991). Ao buscar saber sobre sexualidade as meninas podem ser reprimidas, podem ser envergonhadas, podem ser desafiadas ou julgadas. "Por meio de perguntas, silêncios, brincadeiras ou reprimendas, determinadas atitudes, sentimentos e pensamentos são naturalizados como se fossem os únicos possíveis e aceitos para o modo de ser homem e para o modo de ser mulher" (DINIZ, 2014, p. 139). Alguns sentimentos e atitudes, por vezes proibidos, inadequados, errados ou vergonhosos, são diferentemente distribuídos de acordo com o gênero.

Nesse sentido, ao inventar cientificamente concepções acerca do sexo criou-se também o que se esperar das ações, sentimentos e pensamentos das pessoas que possuem um ou o outro sexo. Laqueur (2001, p. 280) nos diz que "em uma época obcecada pela capacidade de justificar e distinguir os papéis sociais do homem e da mulher, a ciência parece ter encontrado na diferença radical do pênis e da vagina, não só um sinal de diferença sexual como seu próprio fundamento”. (DINIZ, 2014, p. 144)

Uma atividade que tomei conhecimento na escola reforçava por completo essa distribuição desigual de papeis de gênero por meio dos momentos de cuidado da saúde. Era uma ação de saúde realizada em parceria com uma instituição privada de ensino superior. São estudantes de cursos como enfermagem, odontologia, nutrição, que cumprem a carga horária do estágio na escola para a disciplina chamada Saúde do Escolar, do oitavo semestre. Silvia, a orientadora, explicou como funcionava a atividade: "Eles prometeram nos ajudar com a 
questão da saúde dos alunos do sexto ao nono anos e em troca a gente vai ceder os alunos para eles poderem fazer pesquisas" (DIÁRIO, 01 de junho de 2016). Os estudantes universitários aplicavam questionários sócio culturais/psicossociais, além das perguntas sobre saúde, realizavam exames, tipo cálculo do Índice de Massa Corporal, pesagem, acuidade visual, glicemia e pressão arterial. Depois copilavam os dados e repassavam os casos mais sérios para a escola. Os casos repassados geralmente eram em relação às questões psicossociais, que acabavam por revelar abandono familiar, abuso sexual, uso de drogas e/ou álcool, dentre outros. A escola, na figura do SOE, acionavam os pais ou responsáveis para averiguação dos fatos. Quando problemas físicos eram encontrados - necessidade de uso de óculos, sobrepeso, cáries, etc - a aluna ou aluno recebiam um encaminhamento para procurar o centro de saúde ou hospital mais próximo.

Nas palavras de Silvia, este era um bom trabalho para a escola. Devido ao SOE ter tantos problemas relacionados aos casos de violência que ocorriam praticamente todos os dias no ambiente escolar, as questões de saúde ficavam preteridas. Ressaltou que alguns professores não gostavam da presença do grupo ali pois "achavam que estavam terceirizando os serviços da escola" (DIÁRIO, 01 de junho de 2016), falavam isso, segundo ela, por verem a escola responsável também pela saúde dos jovens, depois da educação.

Voltando a explicação. Os temas mais sobressalentes advindo da compilação dos dados dos questionários viram uma "palestra" para os alunos. Explico. Na última vez em que a faculdade esteve no colégio (a incursão ocorre uma ou duas vezes por semestre), os resultados dos questionários apontaram forte conexão dos jovens com bebidas alcoólicas e como naquele momento também estava baixa a participação na campanha do HPV, com o intuito de alertar os jovens sobre estes dois temas, duas palestras foram propostas, uma para o terceiro ano (álcool e HPV) e outra para os sextos anos (HPV).

O ponto que quero chegar é que naquele ambiente de palestras ou "consulta" era legítimo falar de sexo, ver os sexos, perguntar, afinal, sendo o sexo algo científico, o ambiente da saúde seria o mais indicado. Nas turmas da tarde houve uma palestra sobre HPV. Entretanto, mesmo que homens e mulheres adoeçam e sejam responsáveis pelo contágio do vírus, apenas as meninas foram chamadas a comparecer e participar das atividades. Os garotos ficaram em sala, terminando alguma atividade ou no pátio, brincando e jogando bola. A elas, por meio de explicações e dinâmicas, eram requeridas a atenção, a vacina em dia, a 
responsabilização no momento do sexo, o cuidado com a saúde. A eles, nada. Findada a atividade, as alunas ganharam uma lembrancinha como agradecimento, composta por um kit com esmalte e pirulitos e voltaram para suas salas. Interessante notar que este kit é um elemento flutuante entre as categorias de criança (pirulito) e moça (esmalte) e reforçam o que há muito apresentei no capítulo dois e três. Não achei outro lugar mais significativo na escola para a separação dos adolescentes quanto ao gênero do que este.

Particularmente, o que para mim era uma pesquisa em saúde no início da pesquisa, acabou por se tornar também uma discussão de gêneros, baseado no que se discuti aqui e no capítulo três. Incomodava-me muito saber que os meninos não eram chamados às discussões e explicações sobre o HPV. Parecia-me sempre a repetição dos velhos padrões, da responsabilização e medicalização (controle) intensiva do corpo feminino, a educação para ser uma "boa mãe" e cuidadora exemplar. Não só o corpo individual das meninas era chamado ao cuidado, mas a elas a tarefa coletiva de protegerem também os corpos dos meninos, por meio da imunização dos seus, era preconizada. Cada vez mais eu enxergava o HPV como uma doença que precisava ser comunicada e direcionada para múltiplos atores (homens, mulheres, transexuais, homossexuais, jovens e adultos, pobres e ricos) e percebia como a campanha do HPV falhara por destacar apenas as meninas como público alvo. A meu ver, se a vacina era apenas para elas, o cuidado deveria ser de todos.

Consoante Maia et al (2011), a escola é a grande disseminadora e mantenedora das ideias obsoletas em relação às identidades pessoais e ação de mulheres e homens:

A escola não apenas reproduz ou reflete as concepções de gênero e sexualidade que circulam na sociedade, mas que ela própria as produz (LOURO, 2003, p. 81). Com a formação do currículo, a escolha dos conteúdos e materiais a serem trabalhados, o estabelecimento de relações interpessoais entre os membros da escola e os métodos utilizados no ensino, a escola atua em seu papel de instituidora de identidades, ditando não apenas comportamentos, concepções e atitudes a seus alunos, mas também classificando e punindo aqueles desviantes do que é considerado normal (LOURO, 2003; MEYER, 2003). Os resultados de uma educação que coaduna com valores sexistas podem ser diversos, indo desde o sofrimento pessoal motivado pela não aceitação social das diferenças individuais até o fracasso escolar. (MAIA et al, 2011, p. 26) 
São vários os mecanismos que estabelecem padrões comportamentais e hierarquias sociais entre meninos e meninas. E continua-se "um exemplo seria a não neutralidade dos materiais de apoio ao processo de ensino-aprendizagem escolar, tais como as mensagens sexistas existentes nos vídeos, livros, revistas e jornais" (MAIA et al, 2011, p. 27), as práticas de atividades físicas, escolha das brincadeiras, até mesmo o ato de apagar do quadro negro. Dentre eles, podem-se apontar as atividades extraclasses como a palestra apresentada e todo o programa de vacinação do HPV desenhado no GDF.

Embora a participação em algumas ações sexistas da escola (entende-se todo o conjunto de profissionais envolvidos), Maia et al (2011) diz que não se pode atribuir toda a culpa a ela. Como uma instituição imersa numa sociedade e cercada por pessoas que de certa forma cobram por uma atuação coadunante com os padrões estabelecidos, afinal "estes valores que consideramos preconceituosos são extremamente arraigados em nossa cultura e que, devido aos processos de naturalização, passaram a ser inquestionáveis” (p. 39) e dificilmente percebidos. A escola trabalha em conjunto e um desses parceiros é família, e por tabela, sua formação religiosa.

A religião e os preceitos morais para alguns pais e mães são considerados como os mais fortes princípios para a não vacinação e reafirmação do lugar de cada gênero. André, pai evangélico, ajuda a ilustrar isso:

Natália: André, como você trata essa questão com a Bruna? Como é essa questão da sexualidade em casa?

André: Assim, sou de uma formação cristã. Eu sou da congregação cristã do Brasil da $\mathrm{CCB}$, da igreja do véu pra quem não conhece. A gente da igreja do véu nos consideramos tradicionais. Falando de mim, eu particularmente casei virgem com a minha esposa, nós nos casamos virgens, nem um dos dois conhecia homem e nem mulher. (...) Eu tenho dezesseis anos de casado e até hoje não tive nenhuma doença sexual, nem a minha esposa, sou heterossexual e sou monogâmico e faço questão de afirmar isso. Então, vejo os benefícios que isso traz pro meu casamento, pra minha saúde, pra saúde da minha esposa. (...) A Bruna vai pra igreja, a gente não obriga, porque eu penso que essa questão é individual, a gente faz o que a palavra de Deus manda, de dar o ensinamento, ensinar a criança no caminho que ela deve andar. Quando ela estiver adulta, ela vai saber se comportar. Resumindo, a gente tenta passar para ela o lado positivo de você ter uma vida sexual preservada, sem muitos parceiros. A gente trabalha muito isso com ela. (DIÁRIO, 14 de abril de 2016) 
Este pai falou que se considerava "aberto", por deixar a filha "livre" para fazer as próprias escolhas, mas era uma liberdade a qual encerrava-se nos próprios valores religiosos que "trabalhava" com a menina. E mais, ele pareceu ser um pai que não via correlação entre aplicar a vacina e a filha se sentir apta para fazer sexo, já que esta era uma das muitas histórias que ele disse ter ouvido na escola. Penso que ele se sentia muito confiante quanto aos ensinamentos (religiosos) dados a ela.

Dona Maria, a avó que apresentei agora a pouco, evangélica da Igreja Universal, não considera que sua religião interfira diretamente nas escolhas sobre sua saúde ou sobre a saúde da neta. Mas relatou um fato interessante

Eles [os pastores] falam pra a gente se cuidar, não deixar de cuidar da saúde, mas quando a conversa é mais profunda [o que inclui sexualidade, segundo ela], são as esposas deles que conversam com a gente. Elas fazem reuniões com as mulheres e falam 'Vamos cuidar, vamos fazer exames'. (DIÁRIO, 20 de agosto de 2016)

Sobre sexo algo é dito, mas de modo regulado. Boa parte dos meus entrevistados era de religiões evangélicas, mas quase nenhum deles representou o papel conservador e mal informado como pessoas da escola e do próprio centro de saúde haviam me falado. Ouvi respostas parecidas com a de Inês, orientadora da escola: "A mãe não quis deixar vacinar porque a filha vai transar, sabe, são tudo evangélico" (DIÁRIO, 12 de dezembro de 2015). Em inúmeros relatos, há a estreita aproximação da vacina ao início da vida sexual, mas neste caso pesquisado, fazer uma conexão pontual com o grupo evangélico se mostraria um grande salto, revelador das opiniões sobre as "outras" religiões dos "outros". Lembro aqui que Mônica era católica.

$\mathrm{Na}$ verdade, este é um assunto bem controverso. A medida polêmica divide opiniões. Trago um fragmento da reportagem de Barros (2014) sobre diferentes posicionamentos das religiões:

Líder da Assembleia de Deus Vitória em Cristo, o pastor Silas Malafaia acredita que há desinformação. "A vacina é preventiva e não caracteriza promiscuidade. Não há princípio religioso que defenda isso. Pelo contrário, Deus diz que devemos cuidar da saúde e do corpo", diz. No Blog da Família, voltado para cristãos e que não retrata a opinião da Igreja Católica, os pais são orientados a investigar os riscos. "Quando suas adolescentes retornarem à escola, será oferecida a vacina do HPV. É necessária a 
autorização dos pais e oferecida a opção para os pais de se oporem a esta vacina", informa. Com base no alerta, visto mais de 3 mil vezes, uma mãe desistiu de imunizar a filha de 12 anos. "Senti que seria como se estivesse liberando minha filha para iniciar a vida sexual. Li a orientação e meu coração ficou em paz”, postou. (BARROS, 2014).

Algumas meninas que entrevistei se mostraram mais conservadoras, visto que essas expectativas eu imaginaria encontrar apenas entre os genitores. Ainda sobre o grupo focal, quando perguntei o porquê do público da vacina ser dos nove aos trezes anos, elas me responderam várias coisas e interligaram os pontos de religião e sexo, o que facilitou minha tarefa:

Helena: Hoje em dia as meninas estão cada vez tendo relações sexuais mais novas. Então eles queriam precaver com essa vacina [HPV] as meninas de doze, treze anos, as quais eram menos prováveis que tivesse iniciado a vida sexual.

Flávia: Hoje em dia as meninas são assim mesmo, mas enfim.

Natália: É uma preocupação válida para vocês?

Flávia: É uma preocupação válida no meu ponto de vista porque nenhuma de nós está preparada pra uma coisa desse tipo [sexo], além do nosso corpo ainda estar se formando.

Patrícia: Além de essas coisas serem só pra vida adulta, né gente?

Helena: É! Por favor!

Flávia: É uma coisa que a sociedade mais jovem deve repensar esse tipo de atitude, porque não é uma coisa certa. Vida sexual que eu acho que é mais para os adultos e não para nós.

Helena: Não sei... Mas eu acho que é mais uma questão psicológica e moral da pessoa. Como nós somos adolescentes... Alguns acabam rompendo essa barreira [transando mais cedo] achando que é melhor do que os outros. Eu acho que é isso, que acham que são melhores que os outros, porque já tiveram esse tipo de experiência.

Patrícia: Eu acho que é uma coisa de valores morais da pessoa, de esperar ficar mais velha, ter maturidade suficiente, estar psicologicamente pronta para isso.

Natália: E a religião, influencia em alguma escolha na vida de vocês?

Flávia: sim, a vida que você quer levar tem a ver com a religião também. Porque, por exemplo, eu sou criada com princípios que têm a ver com aquela religião, então eu faço escolhas que têm a ver com os princípios da religião. Então influencia. E em várias escolhas de vida. Por exemplo, vou pra tal lugar e vou usar a roupa que eu quero, mas eu prefiro usar uma roupa que me conserve mais. Se for pra usar um tipo de linguagem, eu prefiro usar um que seja mais conservador, sem palavrão. Não sentar de pernas abertas e não falar todo tipo de assunto, entende? (DIÁRIO, 04 de julho de 2016). 
Cada uma a sua maneira posicionou seus valores sobre a vivência de sua sexualidade. Mesmo não falando diretamente em casa ou na escola sobre este tema (tirando Helena que parece ter espaço com mãe, por meio das brincadeiras), essas meninas mostram que possuem opinião. E para haver opinião, falar disso ou ouvir sobre isso é necessário. Então, cabe perguntar: há um silêncio sobre sexo? Foucault (1988) defende que não. Fala-se muito sobre sexo. Entretanto, "o que é próprio das sociedades modernas não é terem condenado o sexo a permanecer na obscuridade, mas sim o terem-se devotado a falar dele sempre, valorizando-o como o segredo" (FOUCAULT, 1988, p. 42).

Apesar da grande diferença nas concepções sobre vacina vistas até aqui e o seu lugar na dinâmica do cuidado à criança/adolescente, sobressai em todas as falas uma perspectiva que aproxima de modo contundente as diferentes tomadas de decisões acerca de vacinar ou não a/o filha/o: proteção, responsabilidade, cuidado. O que pode ser observado é que hoje o cuidado com os filhos tem experimentado mudanças, pois os campos sociais em que todos nós estamos vivem se transformando. Mesmo no Brasil, onde temos uma forte cultura de imunização, a vacina ultrapassa a ordem biomédica e se reconfigura dentro dos lares, das escolas, das cidades e governos. Mas, de modo lento ainda.

Por fim, estes tantos e complexos caminhos que foram percorridos na tentativa de se entender, minimamente, os sentidos que estão por trás da vacina do HPV, querem demonstrar que a imunização ultrapassou definitivamente o campo da saúde e passa a se localizar no âmbito sócio cultural. Se há a utilização de vacinas espirituais segundo Chidassicua (2011), “mães da vacina”, vacinas dispensáveis e as indispensáveis e a religião e o sexo interferindo na concepção social de uma vacina, que neste caso é a do HPV, prova-se então o amplo mundo social desta. Mundo este que vai além dos posicionamentos apresentados, marcando o existente exercício da autonomia individual na administração do corpo na atualidade (CUNHA; DURAND, 2011). 


\section{CONSIDERAÇÕES FINAIS}

Vacina é uma substância e uma tecnologia, vacinação é uma política. Ambas, dadas as dificuldades de se enfrentar as causas de uma doença, destacam-se como uma solução aparentemente simples de se implantar e obter bons resultados (WAILOO et al, 2010). Mas não são. Vacinas, e muito menos as políticas que as envolvem, não são entidades neutras, mas sim locais de posicionamento cultural, social e político. E a vacinação do HPV não foge à regra.

Diante destas considerações, a chegada às páginas finais desta dissertação me faz relembrar o longo caminho que percorri para conhecer, ao menos um pouco, o mundo social que circunda o HPV e sua trajetória dentro de uma escola pública do DF. Desde a introdução, a metodologia, o traçado histórico das vacinas, a apresentação do vírus HPV, a contextualização da escola do Gama, o relato e as discussões que surgiram a partir do dia da vacinação e os sentidos do cuidado por parte de mães e pais, todos estes recortes intentaram dar conta de apontar o quanto se tem por detrás de uma "aparentemente singela" política vacinal. O mundo da vacina HPV é rico e diversificado. No texto, desde a abertura e mais os quatro capítulos desta dissertação, esta riqueza e diversidade estão alinhavadas por um só fio: os atores sociais.

$\mathrm{Na}$ introdução, ao descrever a estrutura do trabalho, a entrada em campo e a metodologia, é a voz da antropóloga que já dá início das análises sobre a pesquisa. As fotografias também entram neste ato. Contar sobre a experiência visual com as fotografias e usá-las ao longo do texto foi um processo experimental fomentador de novas questões ao fazer antropológico, sempre guiado pela pergunta: "O que as imagens podem exprimir melhor que as palavras e em que podem enriquecer o saber antropológico?” (MACDOUGALL, 1994). As fotografias não foram um obstáculo à objetividade da antropologia, mas sim, uma solução para lidar com algumas problemáticas que não encontram tão eficaz representação por meio apenas de palavras.

No primeiro capítulo, o ator principal é o Estado. A partir dele, todos os outros assuntos despontam, como a história das vacinas, as políticas públicas em saúde, os programas de vacinação, o HPV. Este capítulo foi pensado como base para as discussões que ocorreriam posteriormente, pois segundo Hochman (2011), a história da imunização e das vacinas tem 
muito a celebrar, porém sem deixar de ser herética e incômoda. A análise histórica produz reflexões acerca do tempo, do espaço, das contingências e complexidades, as quais podem e devem ser usadas ao se olhar para o surgimento e expansão da vacina HPV enquanto fenômeno vacinal.

No capítulo dois, uma escola pública do Gama foi o espaço escolhido para observar mais detalhadamente a vacinação. Aqui são as meninas e os meninos que dão o tom, picham e grafitam um pouco sobre seu universo jovem e sobre esta escola. A “zoação” se faz presente para marcar as relações sociais ali existentes e a vacina.

No capítulo terceiro, novamente alunas e alunos ajudam a traçar a linha etnográfica que perpassa os argumentos conceituais do capítulo. Mas não só eles, conto também com professores e profissionais da saúde, atores principais aqui, que participaram do dia da vacinação e sustentam a controvérsia saúde-educação acerca do HPV. Chamo-o de "capítulo coração", por conter a descrição do "Dia D" do HPV na escola, afinal, foi este dia que despertou as análises mais densas acerca do fenômeno vacinal, como por exemplo, a divisão de gênero que a vacina evocou.

Por fim, no último capítulo, chamo à cena as mães e pais, como protagonistas da vez. Prometendo benefícios contra perigos incertos e futuros, a vacina se polarizou entre otimismo e ceticismo para estes pais e mães. Surgiu uma controvérsia não unidimensional, mas sobre valores das famílias, papel do governo, confiabilidade na ciência e nas indústrias, supervisão da sexualidade. Religião e sexo foram tidos como protagonistas empíricos sobre esta escolha. De todo modo, o cuidado revelou-se uma categoria elástica, ao abranger diferentes posicionamentos sobre a vacinação. É importante frisar que os atores sociais ao longo da dissertação foram pensados comparativamente e atuaram de forma concomitante.

Desde o início, o debate sobre o HPV foi envolto em um redemoinho de comentários sobre vacinação nas escolas, a proteçao das meninas, o câncer de colo de útero, mas raras às vezes como uma doença sexualmente transmissível. Pode-se entender que o resultado deste distanciamento da sexualidade tem se configurado uma oportunidade perdida para falar sobre a saúde sexual e alfabetização sexual, temas que se mostraram frágeis ao longo da discussão.

Este fato pode servir como uma evidência valiosa das próprias tensões subjacentes em nossa sociedade, acerca do papel das escolas, da gestão da sexualidade, da influência da família, do lugar da saúde pública e suas atribuições. De fato, este debate sobre a vacina contra o HPV 
é, ao mesmo tempo, uma questão biomédica e sociocultural que se desenrola em múltiplos estágios no mundo, cada um com sua história particular e uma cultura. Por isso é necessário prestar atenção às perspectivas representadas, às vozes excluídas e às posições dos diversos atores, incluindo os pais, o estado, a escola, os políticos de saúde. Pode-se aprender assim como navegar dentre as controvérsias, as (in)certezas biológicas e os sujeitos que manejam a vacina - ou seja, navegar por seu mundo social.

Vale destacar e é muito caro marcar isso que embora a variedade de atores sociais citados, esta vacinação do HPV, desenhada no DF, pertence ao mundo das mulheres. Foram elas as escolhidas como o público alvo (meninas), estavam na escola organizando e divulgando a vacina (coordenadora, orientadoras e professoras), são elas que decidem acerca da vacinação (mães) e aplicam a vacina (enfermeiras). Poucos foram os homens contatados que tiveram participação ativa neste processo. Isto acaba por reafirmam várias premissas que foram deixadas ao longo do texto, como o papel predominantemente de cuidadora destinados às mulheres, a responsabilidade e autogestão com a saúde, dentre outras.

Há mais a dizer. Esta pesquisa nunca intentou encerrar-se nas premissas apresentadas. Afinal, novos horizontes estão sempre se abrindo, pesquisas etnográficas não se pretendem permanentes, as mudanças são válidas e importantes. E uma dessas mudanças reverberou mais uma vez o mundo social do HPV: a inclusão dos meninos na política pública vacinal contra o vírus. A matéria abaixo destacou:

A partir do mês de Janeiro, a rede pública de saúde vai passar a oferecer a vacina contra o HPV para meninos de 12 a 13 anos como parte do Calendário Nacional de Vacinação. A faixa etária, de acordo com o Ministério da Saúde, será ampliada gradativamente até 2020, período em que serão incluídos meninos de 9 a 13 anos. A expectativa da pasta é imunizar mais de 3,6 milhões de meninos este ano, além de 99,5 mil crianças e jovens de 9 a 26 anos que vivem com HIV/aids no Brasil. Serão adquiriras, ao todo, 6 milhões de doses ao custo de $\mathrm{R} \$ 288,4$ milhões. De acordo com o governo federal, o Brasil é o primeiro país da América Latina e o sétimo no mundo a oferecer a vacina contra o HPV para meninos em programas nacionais de imunização. Estados Unidos, Austrália, Áustria, Israel, Porto Rico e Panamá já fazem a distribuição da dose para adolescentes do sexo masculino. O esquema vacinal contra o HPV para meninos será de duas doses, com seis meses de intervalo entre elas. (BRASIL, 2017)

A partir do início do ano de 2017, os meninos passaram a ser o mais novo alvo da vacina HPV. Muitos questionamentos estão sendo colocados a essa recente política. De quem 
veio a pressão para a inclusão dos homens? Frente a uma vacina que endossava a proteção do colo do útero, tornando-se assim predominantemente feminina, que discursos serão usados agora? A que proteger agora? Continuar-se-á falando em proteção do corpo ou se partirá para esclarecer que a vacina protege também contra uma DST? Quanto aos comprometimentos morais, quais serão invocados? A vacina, fortemente associada aos corpos das mulheres, poderá (deverá) ser recodificada útil para o corpo masculino. De todo modo, a inclusão de homens no processo vacinal se mostra per si inovadora, pois eles também serão chamados ao comprometimento "corporal", à disciplina com as doses, à gestão da saúde, as quais a vacina evoca, passando por medidas parecidas com as das mulheres.

Em se tratando de um país apontado como machista por algumas interlocutoras, cujos homens não procuram médicos ou evitam o sistema de saúde, como se daria este processo? A adesão à vacina seria menor? São perguntas que requerem tempo para se formular respostas. A tendência é que outros tipos de câncer causados pelo HPV venham à tona, como o de pênis, o de ânus e o de boca, o que pode dar visibilidade a diferentes identidades sexuais, como aos homens homossexuais. As palavras da pesquisadora Anne Szarewski, do Reino Unido, sintetizam uma possível preocupação:

É ruim o suficiente sugerir às pessoas que sua filha de 12 anos de idade pode precisar de uma vacina contra uma infecção sexualmente transmissível. Mas eu ficaria ainda mais interessada em ver a resposta ao sugerir aos pais que eles deveriam vacinar seus meninos aos 12 anos no caso de eles se tornarem gays ${ }^{67}$. (SZAREWSKI, 2009 apud WAILOO et al, 2010, p.113, tradução nossa)

Os homens homossexuais serão chamados à campanha ou apenas irão ser vacinados automaticamente, já que agora a vacina é para os meninos? O advento da Gardasil para o público masculino poderá aguçar este dilema, configurando-se em mais uma controvérsia da vacina $H P V$. Se a vacinação dos meninos realmente vai revelar-se uma intervenção de saúde pública aconselhável e transformadora, esta é uma das dúvidas que permanecem abertas. Cabem novos estudos que acompanhem os desafios masculinos da vacina HPV.

\footnotetext{
${ }^{67}$ It is bad enough suggesting to people that their 12 -year-old daughter might need a vaccine against a sexually transmitted infection. I would be interested to see the response of suggesting to parents that they should vaccinate their boys at 12 in case they become gay.
} 
Claramente, o significado e as implicações a longo prazo desta vacina permanecerão ativas, tanto para homens quanto para mulheres, demonstrando assim a multiplicidade de fenômenos e posições que as vacinam despertam. Ter isso em mente é importante, visto que as pessoas, por vezes, ainda se mostram presas à naturalização das práticas da vacina, como expressado nos versos:

\section{Porém, vamos ser civilizados E aceitar a boa vacinação}

A vacina HPV foi considerada, dentre os atores sociais desta pesquisa, um avanço para a saúde, porém revelou-se estar na contramão dos debates sobre a moralidade, sexualidade e bom governo na maioria dos espaços, seja na escola ou dentro de casa. Levantando questões de eficácia, controle social ou igualdade, estes caminhos de análises e reflexões não desaparecerão da área biomédica ou dos embates sociais, frente aos corpos jovens femininos, e agora aos mais recentes, aqueles que socialmente foram construídos para serem forte e saudavéis, os corpos masculinos. 


\section{REFERÊNCIA BIBLIOGRÁFICA}

ABRAMOVAY, Miriam (Coord.). .Escolas inovadoras: experiências bem-sucedidas em escolas públicas. Brasília: UNESCO, 2003. p. 428

ACHUTTI, L.E. Fotoetnografia da Biblioteca Jardim. Porto Alegre: Editora da UFRGS: Tomo Editorial, 2004. 319 p.

ALTMANN, Eliska. O real imaginado: etnografia, cinema e surrealismo em Jean Rouch. Mana, Rio de Janeiro,v.16, n.1, p. 233-236, abr. 2010.

AMERICO, Carlos. [Lançamento da vacinação contra HPV]. Portal da Saúde, Brasília, 10 mar. 2014. Disponível em: <http://portalsaude.saude.gov.br/index.php/o-

ministerio $/ \mathrm{principal} / \mathrm{secretarias} / 418$-sas-raiz/dapes $/$ saude-da-mulher?start $=60>$. Acessado em: 16 fev. 2017.

APLICATIVO vacinação em dia. Programa Nacional de Imunização, Brasília, ago. 2013. Disponível em: < http://portalarquivos.saude.gov.br/campanhas/pni/>. Acessado em:_30 nov. 2016.

AUDENZI, P.; ORTEGA, F. O estatuto da medicalização e as interpretações de Ivan Illich e Michel Foucault como ferramentas conceituais para o estudo da desmedicalização. Interface comun. saúde educ. (online), v.16, n.40. jan./mar. 2012. Disponível em: < http://www.scielo.br/scielo.php?script=sci_issues\&pid=1414-3283\&lng=en\&nrm=iso $>$. Acessado em: 3 jan. 2017.

AUGÉ, Marc (1992).Não lugares: introdução a uma antropologia da sobremodernidade. Lisboa: $90^{\circ}, 2005$.

AYRES, Andréia R. G,; SILVA, Gulnar Azevedo e. Prevalência de infecção do colo do útero pelo HPV no Brasil: revisão sistemática. Rev. Saúde Públ., São Paulo, v.44, n. 5, p. 963-974, out. 2010.

BARBIANI, Rosangela et al . Metamorfoses da medicalização e seus impactos na família brasileira. Physis, Rio de Janeiro , v. 24, n. 2, p. 567-587, 2014 . Available from <http://www.scielo.br/scielo.php?script=sci_arttext\&pid=S010373312014000200567\&lng=en\&nrm=iso $>$. access on 22 Feb. 2017.

BARBIERI, C.; COUTO, M. Cuidar e (não) vacinar no contexto de famílias de alta renda e escolaridade em São Paulo, SP, Brasil. Ciênc. saúde coletiva, Rio de Janeiro, v.20, p. 105-114, jan. 2015. 
BARBIERI, Carolina Luísa Alves. Cuidado infantil e (não) vacinação no contexto de famílias de camadas médias em São Paulo/SP. São Paulo, 2014. Tese (Doutorado) Faculdade de Medicina, Universidade de São Paulo, São Paulo. 2014.

BARROS, Maria Luiza. HPV: a resistência religiosa. Disponível em:<http://odia.ig.com.br/noticia/rio-de-janeiro/2014-03-12/hpv-a-resistenciareligiosa.html>. Acessado em: 31 jan. 2017.

BEZERRA, Natália Almeida. Bombinha, reloginho ou pera: o uso de equipamentos biomédicos no cuidado da saúde de pessoas vivendo com hipertensão e diabetes na Guariroba, Ceilândia, DF. Brasília, 2011. 95f. Monografia (Bacharelado em Ciências Sociais) - Universidade de Brasília, Brasília. 2011.

BONETTI, A.; FLEISCHER. S. (Orgs.). Entre saias justas e jogos de cintura. Florianópolis: Editora Mulheres; Santa Cruz do Sul: EDUNISC, 2007.

BOURDIEU, P. Questão de sociologia. Rio de Janeiro: Marco Zero, 1983.

BRASIL, Cristina Índio do.Campanha de vacinação contra HPV tem baixa procura este ano. Agencia Brasil, Brasília, jun. 2015. Notícias. Disponível em: < http://www.ebc.com.br/noticias/2015/06/campanha-de-vacinacao-contra-hpv-tem-baixaprocura-este-ano $>$. Acessado em: 31 jan. 2017.

BRASIL. Decreto n. 78.231de 12 de agosto de 1976. Regulamenta a Lei no 6.259 que define a organização das ações de Vigilância Epidemiológica. Diário Oficial [da] República Federativa do Brasil, Brasília, DF, 13 ago. 1976. Disponível em: http://www.planalto.gov.br/ccivil_03/decreto/1970-1979/D78231.htm. Acessado em: 15 nov. 2016.

BRASIL. Lei Federal n 8.080 de 19 de setembro de 1990. Dispõe sobre as condições para a promoção, proteção e recuperação da saúde. Diário Oficial [da] República Federativa do Brasil, Brasília, DF, 20 set. 1990. Disponível em: <http://www.planalto.gov.br/ccivil_03/leis/L8080.htm>. Acessado em: 15 nov. 2016.

BRASIL. Lei Federal no 8069, de 13 de julho de 1990. Estatuto da criança e do adolescente. Diário Oficial [da] República Federativa do Brasil, Brasília, DF, 27 set. 1990. Disponível em: < http://www.planalto.gov.br/ccivil_03/leis/L8069.htm>. Acessado em: 15 nov. 2016.

BRASIL. Lei no 9.782, de 26 de janeiro de 1999. Define o Sistema Nacional de Vigilância Sanitária, cria a Agência Nacional de Vigilância Sanitária, e dá outras providências. Diário Oficial [da] República Federativa do Brasil, Brasília, DF, 27 jan. 1999. Disponível em: < http://www.planalto.gov.br/ccivil_03/leis/L9782.htm>. Acessado em: 26 ago. 2016.

BRASIL. Ministério da Saúde. Centro Cultural da Saúde. Revista da vacina: dois séculos de vacina no Brasil. [Brasília, [200?]]. Disponível em: <http://www.ccms.saude.gov.br/revolta/ltempo.html>. Acessado em: 6 mar. 2015. 
BRASIL. Ministério da Saúde. Comissão Nacional de Incorporação de Tecnologias no SUS (CONITEC). Vacina contra HPV na prevenção de câncer de colo do útero. Brasília, 2013. Relatório de Recomendação da Comissão Nacional de Incorporação de Tecnologias no SUS CONITEC, n. 82. Disponível em: < http://conitec.gov.br/images/Incorporados/VacinaHPVfinal.pdf >. Acessado em: 10 jan. 2017.

BRASIL. Ministério da Saúde. MS reforça importância da segunda dose da vacina. Portal Brasil. Brasília, 2 out. 2014. Saúde. Disponível em: http://www.brasil.gov.br/saude/2014/10/ministerio-da-saude-reforca-importancia-dasegunda-dose-da-vacina. Acessado em: jun. 2014.

BRASIL. Ministério do Desenvolvimento Social e Combate à Fome. Programa Bolsa Família. Disponível em: < https://mds.gov.br/assuntos/bolsa-familia>. Acessado em: nov. 2016.

BRITO, Monique Araújo de. Medicalização da vida: ética, saúde pública e indústria farmacêutica. Ciênc. saúde coletiva, Rio de Janeiro, v. 17, n. 9, p. 255-255, 2012 . Disponível em: <http://www.scielo.br/scielo.php?script=sci_arttext\&pid=S141381232012000900036\&lng=en\&nrm=iso >. Acessado em: 17 Feb. 2017.

CAMARGO, Alexandre de Paiva Rio. Sociologia das estatísticas: possibilidades de um novo campo de investigação. Hist. cienc. saude-Manguinhos, Rio de Janeiro, v. 16, n. 4. p.903925. 2009.

CAMPOS, Marcus Vinicius. O conceito de prevenção no discurso da Organização Pan Americana da Saúde. Campinas, SP, 2002. Dissertação (Mestrado - Pós-Graduação em Saúde Coletiva) - Universidade Estadual de Campinas. Faculdade de Ciências Médicas. Campinas-SP, 2012.

CARRARA, Sergio. Tributo a Vênus: a luta contra a sífilis no Brasil, da passagem do século aos anos 40. Rio de Janeiro: Editora FIOCRUZ, 1996. 339 p.

CARVALHO, Alice Teles de; ALMEIDA, Erika Rodrigues de; JAIME, Patrícia Constante. Condicionalidades em saúde do programa Bolsa Família - Brasil: uma análise a partir de profissionais da saúde. Saúde soc., São Paulo, v. 23, n. 4, p. 1370-1382, 2014.

CARVALHO, José Murilo. Os bestializados: o Rio de Janeiro e a República que não foi. São Paulo: Companhia das Letras. 1987.

CASTRO, Priscila da Silva. Gestão coletiva e individual dos corpos. Cad. saúde colet., Rio de Janeiro , v. 21, n. 2, p. 233-234, June 2013 . Available from

$<$ http://www.scielo.br/scielo.php?script $=$ sci_arttext\&pid $=$ S1414-

462X2013000200019\&lng=en\&nrm=iso $>$. access on 22 Feb. 2017.

CÉSAR, Maria Rita de Assis. Da escola disciplinar à pedagogia do controle. São Paulo, 2004. Tese (Doutorado) - Faculdade de Educação, Unicamp. 2004. 
. Gênero, sexualidade e educação: notas para uma "Epistemologia". Educ. rev., Curitiba, n. 35, p. 37-51, 2009.

Pensar a educação depois de Foucault. Revistacult, São Paulo. Seção Dossiês. Disponível em: < http:// revistacult.uol.com.br/pensar-a-educacao-depois-de-foucault/>. Acessado em 17 fev. 2017.

CHARBONNIER, Georges. Arte, linguagem, etnologia: entrevistas com Claude LéviStrauss. Tradução Nícia Adan Bonatti. Campinas, SP: Papirus, 1989. 144 p.

CHIDASSICUA, José Braz. Práticas e saberes socioculturais sobre saúde, doença e morte de crianças de 0 a 5 anos de idade, na comunidade de Mopeia (Moçambique). São Paulo, 2011.179f.Dissertação (Mestrado em Saúde Materno Infantil) - Faculdade de Saúde Pública, Universidade de São Paulo, São Paulo. 2011.

COLUCCI, C. Vacinação contra vírus HPV divide opinião de médicos. Jornal Folha de São Paulo. Disponível em: <http://www1.folha.uol.com.br/cotidiano/2014/02/1406378vacinacao-contra-virus-hpvdivide-opiniao-de-medicos.shtml $>$. Acessado em:16 jun. 2015.

COMPANHIA DE PLANEJAMENTO DO DISTRITO FEDERAL (CODEPLAN). Resultado da PDAD sobre o Gama. Brasília, 2011. Disponivel em: $<$ http://www.codeplan.df.gov.br/noticias/noticias/item/2635-codeplan-divulga-resultado-dapdad-sobre-o-gama.html>. Acessado em: 20 fev. 2017.

COSTA, André Oliveira; ENDO, Paulo César. Corpo, transmissão e processo civilizador: Sigmund Freud e Norbert Elias. Trivum, Rio de Janeiro , v. 6, n. 2, p. 16-32, dez. 2014 . Disponível em: <http://pepsic.bvsalud.org/scielo.php?script=sci_arttext\&pid=S217648912014000200004\&lng=pt\&nrm=iso >. Acessado em: 17 fev. 2017.

COSTA, Ediná Alves (org.). Vigilância sanitária: temas para debate. Salvador: EDUFBA, 2009. 240 p.

COSTA, Everaldo Batista da; PELUSO, Marilia Liuza. Imaginário urbano e situação territorial vulnerável na Capital do Brasil. Biblio3W, v.21, n. 1.151, p.1-36, fev. 2016. Disponível em: < http://www.ub.edu/geocrit/b3w-1151.pdf>. Acessado em: 20 fev. 2017

CUNHA, Manuela Ivone P. da; DURAND, Jean-yves (Orgs.). Razões de saúde: poder e administração do corpo; vacinas, alimentos, medicamentos. Lisboa: Fim de Século: 2011. 230 p.

A dissensão vacinal difusa: corpo, pessoa e sujeitos políticos. In:__ Razões de saúde: poder e administração do corpo; vacinas, alimentos, medicamentos. Lisboa: Fim de Século, 2011. p. 187-229. 
DINIZ, Cassianne Campos. Quem inventou o sexo? experiências cotidianas de crianças e professoras acerca de gênero e sexualidade. 2014. 173 f., il. Dissertação (Mestrado em Antropologia Social) - Universidade de Brasília, Brasília. 2014.

DINIZ, Francisco R. A.; OLIVEIRA, Almeida A. de. Foucault: do poder disciplinar ao biopoder. Scientia, v.2, n.3, p. 1-217, nov.2013-jun. 2014. Disponivel em:

<http://www.faculdade.flucianofeijao.com.br/site_novo/scientia/servico/pdfs/VOL2_N3/F RANCISCOROMULOALVESDINIZ.pdf>. Acessado em: 20 fev. 2017.

DISTRITO FEDERAL. SECRETARIA DE ESTADO DE SAUDE. Vacinação contra o Papilomavírus Humano (HPV) nas escolas - 2013. Brasília, 5 mar. 2013. Disponível em: < http://www.saude.df.gov.br/noticias/item/2681-nota-t\%C3\%A9cnica-hpv.html>. Acessado em: 25 ago. 2015.

DOCUMENTÁRIO. Alguém que você ama: a epidemia do HPV. Wn.com., dez. 2014. Disponível em: <https://wn.com/algu\%C3\%A9m_que_voc\%C3\%AA_ama_a_epidemia_do_hpv>. Acessado em: 15 dez. 2016.

ELIAS, Nobert. O processo civilizador: uma história dos costumes. Rio de Janeiro: Jorge Zahar Editor, 1990. v.1, 271 p.

ELUF NETO, José. A vacina contra o papilomavírus humano. Rev. bras. epidemiol., São Paulo,v.11, n. 3, p. 521-523, Set. 2008.

FASSIN, Didier. Gobernar por loscuerpos, políticas de reconocimiento hacia los pobres y los imigrantes. Cuad. antropol. soc., Buenos Aires, v. 17, n.1, ene.-ago. 2003. P. 51-80.

FEIJO, Ricardo B.; CUNHA, Juarez; KREBS, Lenita S.. Calendário vacinal na infância e adolescência: avaliando diferentes propostas. J. Pediatr. (Rio J.), Porto Alegre, v.82, n. 3, supl. p. 4-14, jul. 2006.

FERNANDES, José Veríssimo et al. Conhecimentos, atitudes e prática do exame de Papanicolaou por mulheres, Nordeste do Brasil. Rev. Saúde Pública, São Paulo, v. 43, n.5, São Paulo, out. 2009. p. 851-858, set. 2009. Disponível em:

<http://dx.doi.org/10.1590/S0034-89102009005000055.>. Acessado em: 7 fev. 2017.

FERNANDES, Tania. Vacina antivariólica: seu primeiro século no Brasil (da vacina jenneriana à animal). Hist. cienc. saude-Manguinhos, Rio de Janeiro , v. 6, n. 1, p. 29-51, June 1999 . Available from <http://www.scielo.br/scielo.php?script=sci_arttext\&pid=S0104$59701999000200002 \& \operatorname{lng}=$ en\&nrm=iso $>$. access on 22 Feb. 2017.

FERRAZ, Ana Lúcia M. C. "O palhaço o que é? É ladrão de mulher". A produção do vídeo etnográfico na pesquisa sobre o Circo-Teatro brasileiro. In: REUNIÃO BRASILEIRA DE ANTROPOLOGIA, 26. 2008. Porto Seguro. Anais... Porto Seguro: ABA, 2008. 
FERREIRA, A. B. H. Novo dicionário de língua portuguesa. Rio de Janeiro: Nova Fronteira, 1986.

FERREIRINHA, Isabella Maria Nunes; RAITZ, Tânia Regina. As relações de poder em Michel Foucault: reflexões teóricas. Rev. Adm. Pública, Rio de Janeiro, v. 44, n. 2, p. 367 383, Abr. 2010.

FONSECA, Claudia. Quando cada caso não é um caso: pesquisa etnográfica e educação. Rev. Bras. Educ. n. 10, p. 58-78, jan.-abr. 1999.

FOUCAULT, Michel. Em defesa da sociedade: curso no College de France (1975- 1976). Tradução Maria Ermantina Galvão. São Paulo: Martins Fontes, 2005.

História da sexualidade 1. A vontade de saber. Rio de Janeiro: Edições Graal, 1988.

. Microfísica do poder. Organização e tradução de Roberto Machado. Rio de Janeiro: Edições Graal, 1984.

O nascimento da biopolítica. Curso dado no College de France (1978-1979).

Tradução Eduardo Brandão. São Paulo: Martins Fontes, 2008.

Vigiar e punir: nascimento da prisão. Petrópolis: Vozes, 1987.

FRANCISCO JR, L; KOK, Glória. Aspectos antropológicos relacionados à Internet: um olhar reflexivo voltado a uma questão bioética da contemporaneidade. Rev. Bioethikos, n.2, p. 212 216. abr.-jun. 2012.

FROTA, A.M.M.C. Diferentes concepções da infância e adolescência: a importância da historicidade para sua construção. Estudos e Pesquisas em Psicologia, EFRJ, RJ, v. 7, n. 1, 2007.

GAZETA, Arlene A. B.. História \& Saúde: com a varíola, nasce a saúde pública. História Viva, São Paulo, n.134, dez. 2014.

GIAMI, Alain. A medicalização da sexualidade. Foucault e Lantéri-Laura: história da medicina ou história da sexualidade?. Physis, Rio de Janeiro, v. 15, n. 2, p. 259-284, 2005.

GOFFMAN, Ervin. A representação do eu na vida cotidiana. Petrópolis: Vozes, 2014.

GRADVOHL, Silvia Mayumi Obana; OSIS, Maria José Duarte; MAKUCH, Maria Yolanda. Maternidade e formas de maternagem desde a idade média à atualidade. Pensando fam., Porto Alegre, v. 18, n. 1, p. 55-62, jun. 2014 . Disponível em $<$ http://pepsic.bvsalud.org/scielo.php?script=sci_arttext\&pid=S1679-

494X2014000100006\&lng=pt\&nrm=iso >. Acessado em: 17 fev. 2017. 
GRAHAM, Janice E.; MISHRA, Amrita. Global challenges of implementing human papillomavirus vaccines. Int J Equity Health, v. 10, jun. 2011. Disponível em: < https://www.ncbi.nlm.nih.gov/pmc/articles/PMC3143925/>. Acessado em: 18 fev. 2017.

Risk, choice and the 'girl vaccine': unpacking human papillomavirus (HPV)

immunisation. Health, Risk \& Society, v.14, p.57- 69, 2012.

GRISCI, Carmem Lígia Iochins. Mulher - mãe. Psicol., Ciênc. Prof., Brasília, v.15, n. 1-3, p. 12-17, 1995.

GUPTA, Akhil. Red Tape: bureaucracy, structural violence, and poverty in India. Durham, NC: Duke University Press, 2012. 368 p.

GURAN, Milton. Fotografar para descobrir, fotografar para contar. Cadernos de antropologia e imagem, v. 10, n. 1, p. 155-165, 2000.

HARTMANN, Marcel. Vacinar ou não vacinar: eis a questão. Estadão, São Paulo, set. 2016. Disponível em: < http://emais.estadao.com.br/noticias/bem-estar,vacinar-ou-nao-vacinar-eisa-questao,10000074325>. Acessado em: 3 jan. 2017.

HOCHMAN, G. A era do saneamento: as bases da política de saúde pública no Brasil. São Paulo: Anpocs/Hucitec, 2012. 261 p.

Vacinação, varíola e uma cultura da imunização no Brasil. Ciênc. saúde coletiva, Rio de Janeiro, v. 16, n. 2, p. 375-386, fev. 2011.

HOCHMAN, G.; FONSECA, Cristina. M. O. A. O que há de novo? Políticas de saúde pública e previdência, 1937-45. In: PANDOLFI, D.(Org.).Repensando o Estado Novo. Rio de Janeiro: FGV, 1999. p. 73-93.

INSTITUTO NACIONAL DO CÂNCER (INCA). Estimativa 2014: incidência do câncer no Brasil. Rio de Janeiro: INCA, 2008. 124 p.

INSTITUTO NACIONAL DO CÂNCER (INCA). HPV e câncer: perguntas mais frequentes. INCA, Rio de Janeiro. Tipos de câncer. Disponível em:

<http://www2.inca.gov.br/wps/wcm/connect/tiposdecancer/site/home/colo_utero/hpvcancer-perguntas-mais-frequentes $>$. Acessado em: 4 dez. 2016.

INSTITUTO NACIONAL DO CÂNCER. Falando sobre o câncer do colo do útero. Rio de Janeiro: Inca, 2011(a). 71 p.

JOVEM processa fabricante de vacina de HPV na França. TerraTV. Disponível em: <http://saude.terra.com.br/videos/jovem-processa-fabricante-de-vacina-de-hpvnafranca,499335.html>. Acessado em: 20 abr. 2014. 
LAROCCA, Liliana Müller; MARQUES, Vera Regina Beltrão. Higienizar, cuidar e civilizar: o discurso médico para a escola paranaense (1920-1937). Interface (Botucatu), Botucatu , v. 14, n. 35, p. 753-766, Dec. 2010 . Disponível em:

<http://www.scielosp.org/scielo.php?script=sci_arttext\&pid=S1414-

32832010000400004\&lng=en\&nrm=iso>. Acessado em: 18 Feb. 2017.

LATOUR, Bruno. Ciência em ação: como seguir cientistas e engenheiros sociedade afora. São Paulo: UNESP, 2000.

LEAL, Aline. Vacina contra HPV para adolescentes passa a ter uma dose a menos. Agência Brasil, Brasília, 5 jan. 2016. Disponível em: <

http://agenciabrasil.ebc.com.br/geral/noticia/2016-01/vacina-contra-hpv-para-adolescentespassa-ter-uma-dose-menos >. Acesso em: 15 nov. 2016.

LEITE NETTTO, Mauro. Nobel de Medicina de 2008 que descobriu relação entre HPV e câncer é destaque de Simpósio de Patologia em SP. FAPESP, São Paulo, [2010]. Disponível em: <http://www.bv.fapesp.br/namidia/noticia/37931/nobel-medicina-2008-descobriurelacao/ > . Acessado em: 16 nov. 2016.

LOURO, G. L. Gênero, sexualidade e educação: uma perspectiva pós estruturalista. Petrópolis: Vozes. 2003.

MACDOUGALL, David. "Mas afinal, existe realmente uma antropologia visual?" In: Catálogo II Mostra Internacional do Filme Etnográfico. Rio de Janeiro: Interior Produções, 1994. p. 71-77.

MACHADO, Paulo R. L. et al . Mecanismos de resposta imune às infecções. An. Bras. Dermatol., Rio de Janeiro, v.79, n. 6, p. 647-662, dez. 2004. Disponível em: <http://dx.doi.org/10.1590/S0365-05962004000600002>. Acessado em: 12 nov. 2016.

MAIA, Ana Claudia Bortolozzi; NAVARRO, Carolina; MAIA, Ari Fernando. Relações entre gênero e escola no discurso de professoras do ensino fundamental. Psicol. Educ., n. 32, p. 25 46, 2011.

MALTA, Deborah Carvalho et al . A Política Nacional de Promoção da Saúde e a agenda da atividade física no contexto do SUS. Epidemiol. Serv. Saúde, Brasília , v. 18, n. 1, p. 79-86, mar. 2009. Disponível em:

<http://scielo.iec.pa.gov.br/scielo.php?script=sci_arttext\&pid=S1679-

49742009000100008\&lng=pt\&nrm=iso >. Acessado em: 21 fev. 2017.

MARTIN, Olivier. Da estatística política à sociologia estatística. Desenvolvimento e transformações da análise estatística da sociedade (séculos XVII - XIX). Rev. bras. Hist. v.21, n.41, p.13 - 34. São Paulo, 2001.

MARTINS, Daiane. Epidemia do século atinge 630 milhões de pessoas no mundo. Diário do Sudoeste, Paraná, 9 abr. 2015. Seção Região. Disponível em: 
<http://www.diariodosudoeste.com.br/regiao/2015/04/epidemia-do-seculo-atinge-630milhoes-de-pessoas-no-mundo/1324728/>. Acessado em:16 nov. 2016.

MINISTÉRIO DA SAÚDE anuncia ampliação da vacinação contra HPV para meninos. Correioweb, Brasília, 11 out. 2016. Brasil/Política. Disponível em: <http://www.correiobraziliense.com.br/app/noticia/brasil/2016/10/11/internas_polbraeco, 552759/ministerio-da-saude-anuncia-ampliacao-da-vacinacao-contra-hpv-para-men.shtml>. Acessado em: 7 fev. 2017.

MORAES, Raquel. DF começa a vacinar meninas contra HPV; meta é atingir 17 mil. G1.DF, Brasília, 3 mar. 2015. Disponível em: <http://g1.globo.com/distritofederal/noticia/2015/03/df-comeca-vacinar-meninas-contra-hpv-meta-e-atingir-17-mil.html $>$. Acessado em: 20 fev. 2017.

MOTA, Murilo Peixoto da. Gênero e sexualidade: fragmentos de identidade masculina nos tempos da Aids. Cad. Saúde Pública, Rio de Janeiro, v. 14, n. 1, p. 145-155, jan. 1998.

MOULIN, Anne Marie. A hipótese vacinal: por uma abordagem crítica e antropológica de um fenômeno histórico. Hist. cienc. saude-Manguinhos, Rio de Janeiro, v.10, p.499-517, 2003. Suplemento 2.

. L'Aventure de la vaccination. Lyon, Fayard, 1996. 498 p.

MPF pede a suspensão da vacina em todo o país. Notícias, Uberlândia- MG, dez. 2015. Disponível em: <http://www.prmg.mpf.mp.br/imprensa/noticias/saude/mpf-pede-aproibicao-da-vacina-contra-o-hpv-em-todo-o-pais>. Acessado em: 26 dez. 2016.

NAKAGAWA, Janete Tamani Tomiyoshi; SCHIRMER, Janine; BARBIERI, Márcia. Vírus HPV e câncer de colo de útero. Rev. bras. enferm., Brasilia , v. 63, n. 2, p. 307-311, Apr. 2010 .

NETO, G. W., \& MAGALHÃES, J. Ação privada e poder público na luta pela instrução Portugal na segunda metade do século XIX. Revista Brasileira de História da Educação, n. 20, p. 15-39. 2009.

NOVAES, H. M. D. (Coord.). Projeto “Avaliação tecnológica de vacinas para a prevenção de infecção por papilomavírus humano (HPV): estudo de custo-efetividade da incorporação de vacina contra HPV no Programa Nacional de Imunizações/PNI do Brasil”". [Brasília], out. 2012. 155 p. Disponível em: < http://docplayer.com.br/19545244-Este-estudofoi-financiado-pelo-departamento-de-ciencia-e-tecnologia-decit-ms-e-pelo-conselho-nacionalde-desenvolvimento-cientifico-e-tecnologico.html> Acessado em: 15 fev. 2017.

OMS. Comissão de Especialistas em Educação em Saúde da Organização Mundial da Saúde. Washington: OMS, 1954. 
PEIRANO, M. Temas ou Teorias? O estatuto das noções de ritual e de performance. Campos - Revista de Antropologia Social, v.7, n.2, p.9- 16. 2006.

Etnografia não é método. Horiz. antropol., Porto Alegre, v. 20, n. 42, p. 377 391, dez. 2014 .

PEREIRA, Alexandre Barbosa. "A maior zoeira” na escola: experiências juvenis na periferia de São Paulo. São Paulo: Editora Unifesp, 2016. 240p.

PEREIRA, Susan M. et al . Vacina BCG contra tuberculose: efeito protetor e políticas de vacinação. Rev. Saúde Públ.,São Paulo, v. 41, Supl. 1, p. 59-66, set. 2007. Disponivel em: $<$ http:/ /www.scielo.br/scielo.php?script=sci_arttext\&pid=S0034-

89102007000800009\&lng=en\&nrm=iso > . Acessado em: 9 fev. 2017.

PIMENTEL, Carolina. Ministério esclarece que menores de 18 podem se vacinar contra hepatite B sem autorização dos pais. Agência Brasil, Brasilia, 10 out. 2010. Disponivel em: $<$ http://memoria.ebc.com.br/agenciabrasil/noticia/2010-10-10/ministerio-esclarece-quemenores-de-18-podem-se-vacinar-contra-hepatite-b-sem-autorizacao-dos-pais $>$. Acessado em: 09 fev. 2017.

PIVETTA, Marcos. Proteção ampliada: testes da vacina contra HPV em homens acirram debate sobre quem deve recebê-la. Pesquisa FAPESP, n. 157, p. 56 a 59, mar. 2009.

QUERINO, Mário. Meninas tomem a vacina HPV. Bahia, 18 mar. 2014. Disponível em: <http://poetamarioquerino.blogspot.com.br/2014/03/meninas-tomem-vacina-hpv.html>. Acessado em: 20 abr. 2016.

QUEVEDO, J.; INÁCIO, M. A nova revolta da vacina? Uma análise sobre os comentários no Facebook do Ministério da Saúde durante a campanha de vacinação do Hpv. In: ENCONTRO E PESQUISA EM COMUNICAÇÃO. COMUNICAÇÃO E GÊNERO, 7., 2015, Curitiba. Anais... Curitiba: UFPR, 2015. p. 52-63. Disponível em:http://www.enpecom.ufpr.br/arquivos-2015/ANAIS_VII_ENPECOM.pdf >. Acessado em: 03 jan. 2017.

RAMOS, F.P. Mas afinal...o que é documentário? São Paulo: Senac. 2008.

RAMOS, Marília Patta; SCHABBACH, Letícia Maria. O estado da arte da avaliação de políticas públicas: conceituação e exemplos de avaliação no Brasil. Rev. Adm. Pública, Rio de Janeiro , v. 46, n. 5, p. 1271-1294, Oct. 2012 . Disponível em:

$<$ http://www.scielo.br/scielo.php?script=sci_arttext\&pid=S0034-

76122012000500005\&lng=en\&nrm=iso>. Acessado em: 18 Feb. 2017.

RANNÃ, W. Os desafios da adolescência. 2005. Disponível em: <http://www2.uol.com.br/vivermente/reportagens/os_desafios_da_adolescencia.html. Acessado em: 15 Dez. 2016. 
RANGEL, Everton. Braziliandancers: a travessia dos corpos em um circo norte-americano. Rio de Janeiro. 2015. Dissertação (Mestrado em Antropologia Social) -Universidade Federal do Rio de Janeiro. 2015.

REZENDE, Joffre M. Varíola: uma doença extinta. In: À sombra do plátano: crônicas de história da medicina São Paulo: Editora Unifesp, 2009. 408 p. Disponível em:< http://www.jmrezende.com.br/variola.htm>. Acessado em: 3 jan. 2017.

RODOLPHO, Adriane Luísa. Rituais, ritos de passagem e de iniciação: uma revisão da bibliografia antropológica. Estudos Teológicos, v. 44, n. 2, p. 138-146, 2004.

RODRIGUES, M.M. A prevenção da decadência: discurso médico e medicalização da Sociedade (Curitiba, 1931-1942). Curitiba. 1997. Dissertação (Mestrado Curso de Pósgraduação em História) - Universidade Federal do Paraná. 1997.

ROHDEN, Fabíola. A arte de enganar a natureza: contracepção, aborto e infanticídio no início do século XX. Rio de Janeiro; FIOCRUZ, 2003. 248 p.

Ginecologia, gênero e sexualidade na ciência do século XIX. Horiz. antropol., Porto Alegre, v. 8, n. 17, p. 101-125, 2002.

ROZENFELD, Suely (org). Fundamentos da vigilância sanitária. Rio de Janeiro: Editora FIOCRUZ, 2000. 301 p.

SA, Teresa. Lugares e não lugares em Marc Augé. Tempo soc., São Paulo, v. 26, n. 2, p. 209229, Dec. 2014. Disponível em:

$<$ http:/ /www.scielo.br/scielo.php?script $=$ sci_arttext\&pid $=$ S0103-

20702014000200012\&lng=en\&nrm=iso > . Acessado em: 20 Feb. 2017.

SANCHES, O.; AMARANTE, C.M.C.; IGUCHI, T., Assessoria estatística e o laboratório de estatística aplicada na Ensp-Fiocruz. Cad. saúde pública. Rio de Janeiro, v.8, n.1, p. 41-49, jan. - mar. 1992.

SCHATZMAYR, Hermann G.. Novas perspectivas em vacinas virais. Hist. cienc. saudeManguinhos, Rio de Janeiro, v.10, s. 2, p.655-669, 2003.

SEGATTO, Cristiane. Vacina contra o HPV no SUS. Vale a pena? Revista Época, n. 27, de 24 de janeiro de 2014. Disponível em: http:/ / epoca.globo.com/colunas-e-blogs/cristianesegatto/noticia/2014/01/vacina-contra-o-bhpv-no-susb-vale-pena.html Acessado em: 22 de agosto de 2016.

SENNA, Mônica de Castro Maia et al. Programa bolsa família: nova institucionalidade no campo da política social brasileira?. Rev. Katálysis, v.10, n.1, p.86-94, jun. 2007.

SENRA, N. de C. Informação estatística: política, regulação, coordenação. Ci. Inf., Brasília, v.28, n.2, p.124-135. maio - ago.1999. 
. O saber e o poder das estatísticas: uma história das relações dos estaticistas com os estados nacionais e com as ciências. Rio de Janeiro: IBGE, 2005.

SEVCENKO, Nicolau. A revolta da vacina: mentes insanas em corpos rebeldes. São Paulo: Scipione, 1993. 88 p.

SILVA, Vagner Gonçalves da. O sentir das estruturas e as estruturas do sentir: a poesia que lévistrouxe. Rev. Antropol., São Paulo, v. 42, n. 1-2, p. 77-96, 1999 .

SOUZA, I.P.M.A. de; JACOBINA, R.R. Educação em saúde e suas versões na história brasileira. Revista Baiana de Saúde Pública, v.33, n.4, p.618-627, 2009.

SOUZA, Liliane Pereira de. A violência simbólica na escola: contribuições de sociólogos franceses ao fenômeno da violência escolar brasileira. Revista Labor. Fortaleza. v.1, n. 7, p. 20-34, 2012.

SZTUTMAN, Renato. A antropologia reversa de Jean Rouch: de "os mestres loucos" a "Pouco a pouco". Devires - cinema e humanidades, Minas Gerais, v.6, n.1. jan.-jun. 2009. p.108-125.

UHL, Kamilla. PSE: vacinação contra HPV nas escolas a partir do dia $1^{\circ}$. Prefeitura de Campos, Rio de Janeiro, fev. 2016. Notícia no Detalhe. Disponível em: <http://www.campos.rj.gov.br/exibirNoticia.php?id_noticia=34702.>. Acessado em: 2 dez. 2016.

VACINA contra HPV para adolescentes passa a ter uma dose a menos. CorreioWeb, Brasília, maio 2016. Publicidade. Disponível em:

<http://www.correiobraziliense.com.br/app/noticia/brasil/2016/01/05/internas_polbraeco, 512890/vacina-contra-hpv-para-adolescentes-passa-a-ter-uma-dose-a-menos.shtml>. Acessado em 14 fev. 2017.

VOGEL, A. Do estado ao estatuto. Propostas e vicissitudes da política de atendimento à infância e adolescência no Brasil contemporâneo. In: PILOTTI, Francisco; RIZZIRI, Irene (Org.). A arte de governar crianças: a história das políticas sociais, da legislação e da assistência à infância no Brasil. Rio de Janeiro: IIN/EDUSU/Amais, 1995. p. 299-382.

WAILOO, Keith et al. Three shots at prevention: the HPV vaccine and the politics of medicine's simple solutions. Baltimore, Md. : Johns Hopkins University Press, 2010.

WEINBERGER, Eliot. "The Camera People”. In: TAYLOR, Lucien. (Ed.). Visualizing Theory, selected essays from V.A.R.,1990-1994. New York and London: Routledge, 1994. p. 3-26. 
ANEXO

\section{Ensaio fotográfico}

\section{Quando a vacina entra na escola}

Olhe, toque seu braço. Ache aquela marca que parece uma cicatriz, a que temos desde bebê. Essa é sua marca de vacina. Só sua. Essa marca é um sinal que o indivíduo carrega no seu próprio corpo e que garante submissões, à norma jurídica e à autoridade sanitária. O fenômeno vacinal é complexo, em especial para a Antropologia, que pensa as diferentes interações entre saúde, sistema biomédico, Estado e indivíduo. Hoje, se privilegia um novo corpo. Há uma vacina recente, realizada apenas em meninas de 09 a 13 anos, contra o Papiloma Vírus Humano (HPV), ministrada para prevenção do câncer de colo de útero. Desde 2013 uma campanha nacional vacinou $93.6 \%$ de corpos no DF com a primeira dose. A vacina suscita problemáticas diferentes. Em especial, por migrar do centro de saúde para as escolas. Tal prática dentro da instituição de ensino, disseminadora de conhecimento e disciplinarizadora, gera fatos interessantes. Conhecer essa atuação é fundamental. O ensaio apresenta o caminho que a vacina percorre dentro de uma escola do DF. As fotos representam desde o momento em que ela é "negociada", entre o Centro de Saúde e a escola, até a pós-vacinação. O projeto fotográfico é parte de uma pesquisa maior e não intenta a tradução completa de uma realidade, mas revelar aspetos sutis do processo vacinal. As imagens foram feitas a partir da etnoficção - técnica de representação onde o grupo pesquisado desempenha um papel, recorrendo à narrativa documental, ficcional ou à imaginação para falar de si.

\section{ENTRADA.}

Foto tirada na sala da direção. É aqui aonde acontece o primeiro contato entre o Centro de Saúde e a escola - a parte mais burocrática do processo. O "posto" avisa que fará uma visita para vacinar as meninas que estejam dentro da faixa etária da campanha. Pede-se à escola que faça a divulgação do evento, que informe aos pais e que explique sobre a vacina do HPV às crianças.

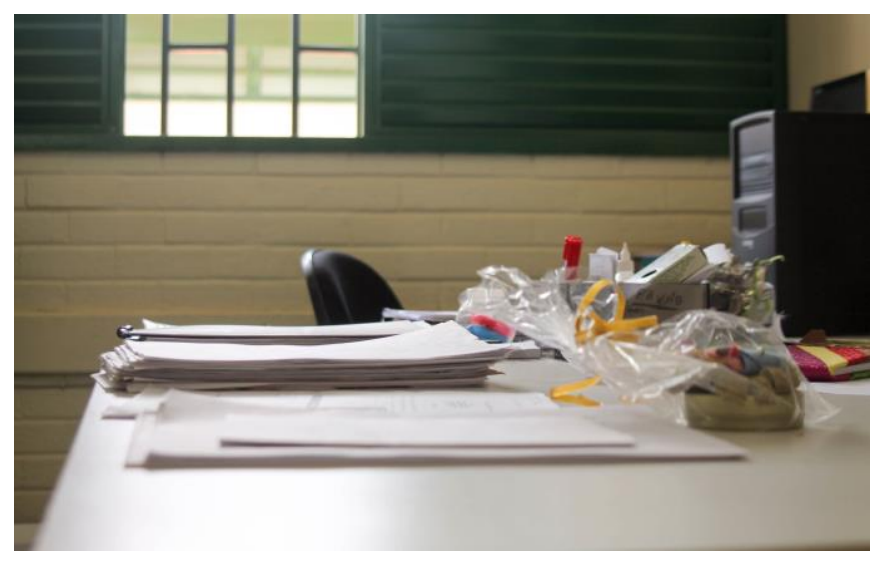




\section{DIVULGAÇÃO.}

Foto feita em sala de aula. Professores e orientadores educacionais põem em prática o aviso e as informações sobre a vacina, com a presença de meninos e meninas.
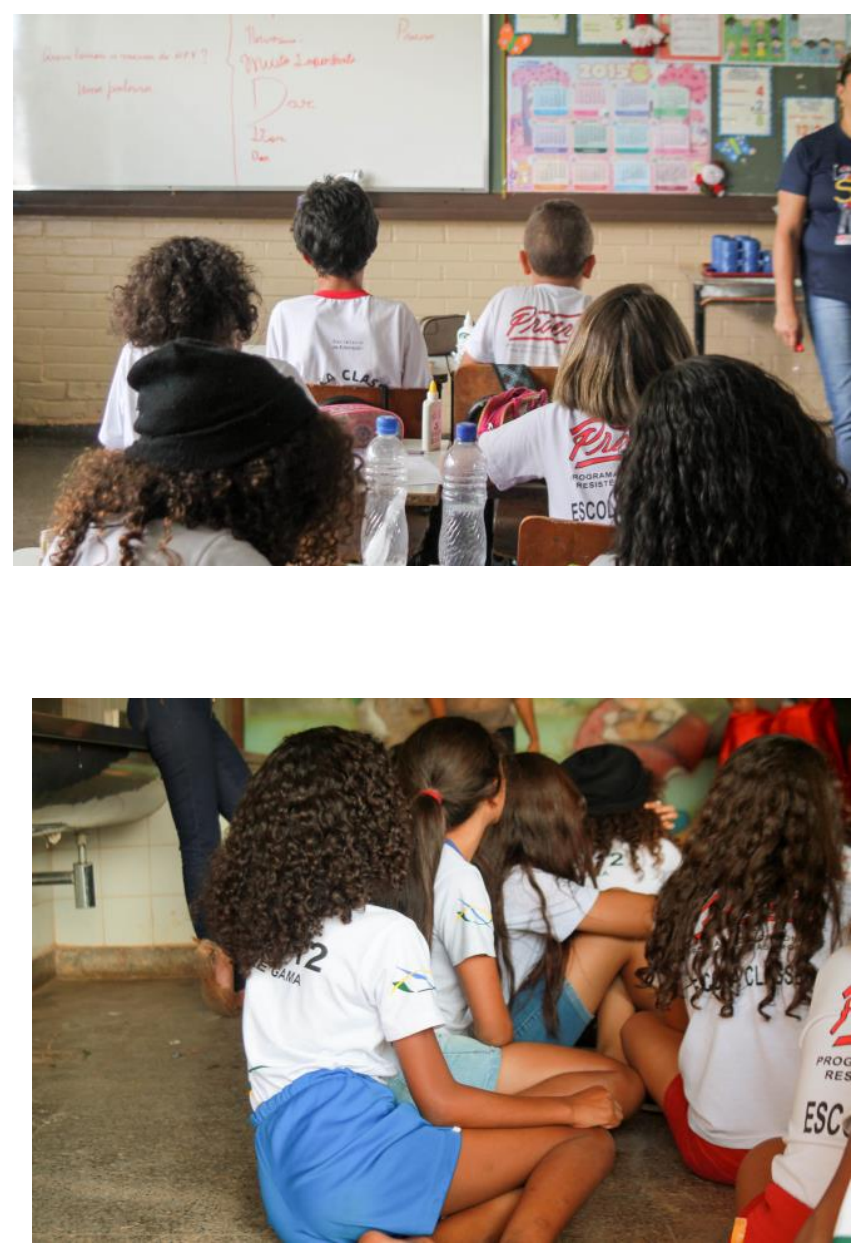

PALESTRA.

Apenas alunas, sob o olhar de suas professoras, acompanham uma palestra sobre o vírus do HPV, feita por uma ginecologista. A intenção é que temas como: tipos de vírus, local da infecção no corpo, primeiros sintomas, apresentação do sistema reprodutor da mulher (útero, em especial) sejam discutidos. Há também um momento "livre", no qual as alunas podem fazer perguntas diversas à médica.

\section{CARTAZES.}

São os meios mais utilizados para a divulgação. Ao todo, contei doze cartazes em toda a escola. Destaque para o cartaz fixado no mural de entrada do colégio. É a primeira informação visual que as alunas e mães/pais se deparam ao chegar ao local, logo abaixo de "bem vindo". 
CENÁRIOS DA VACINAÇÃO.

Esta é a sala do Serviço de Orientação Educacional (SOE), vista da sala dos professores. É nesta sala onde acontecem as vacinações. Equipe de saúde (auxiliar de enfermagem e enfermeira) de um lado e meninas do outro. Apenas a orientadora está presente, para organizar e acalmar/incentivar quem estiver com medo, enquanto uma professora chama as meninas em sala.

\section{CORPOS.}

Meninas e suas marcas de vacina antigas. As garotas se organizam em filas na porta da sala do SOE. Em pequenos grupos, entram na sala, conferem seus dados, informam a dose que vão tomar $\left(1^{\mathrm{a}}, 2^{\mathrm{a}}\right.$ ou $\left.3^{\mathrm{a}}\right)$ e aguardam o cartão de vacina. Aproveitam o momento para compartilhar experiências de suas vacinas anteriores, falar sobre as angústias com esta, ou perguntar algo para a equipe.

\section{PÓS-VACINA.}

Já de volta à sala, pedi às meninas que descrevessem em uma palavra o que a vacina representava para elas. Foram experiências e sentimentos diversos, entretanto a palavra "dor" foi a mais recorrente. Neste momento também pude conhecer como os meninos reagiram à vacinação. Boa parte desconhecia a vacina e alguns ainda aproveitavam para brincar (zoar) com as colegas.
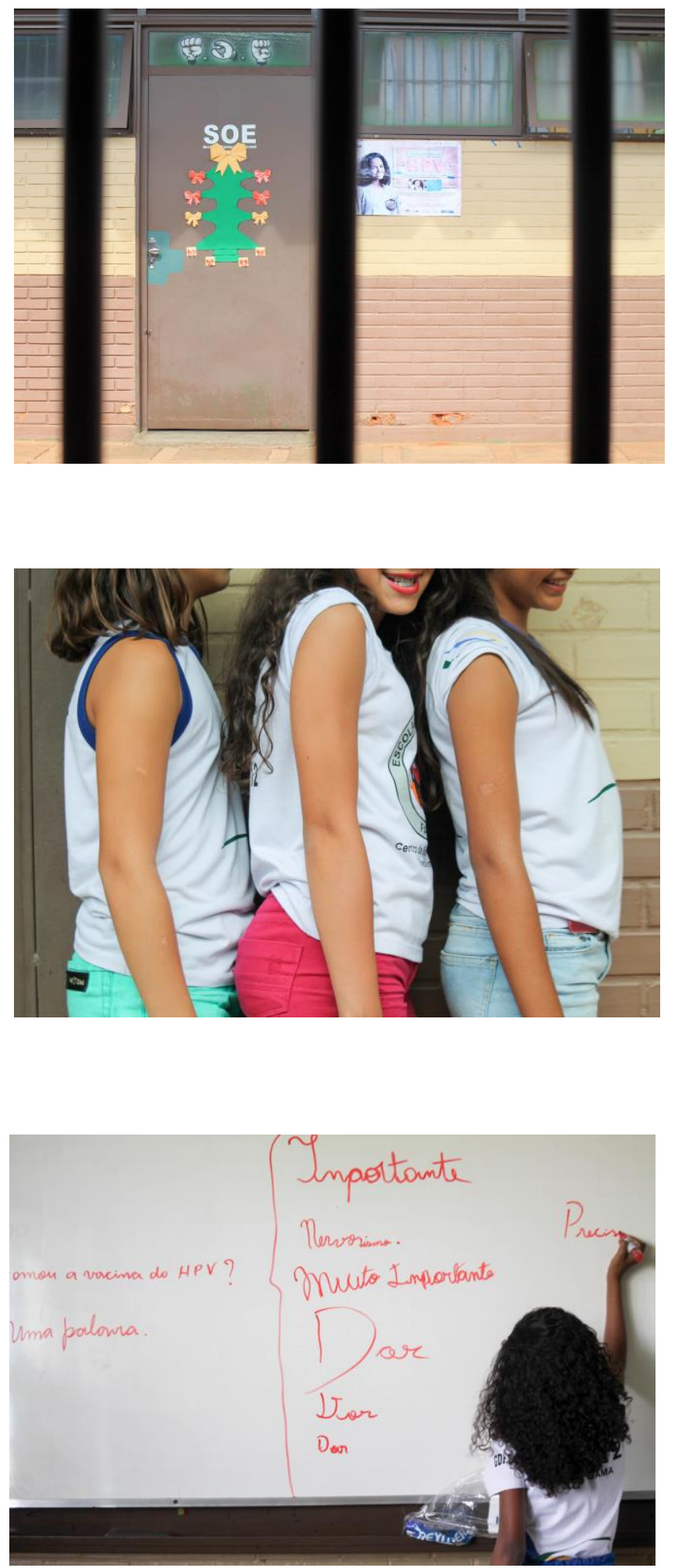


\section{A ESCOLA.}

Vista de um dos corredores da escola. Volta às atividades normais. Final do caminho da vacina. Será que seus efeitos, sentidos, sentimentos cessam aqui?

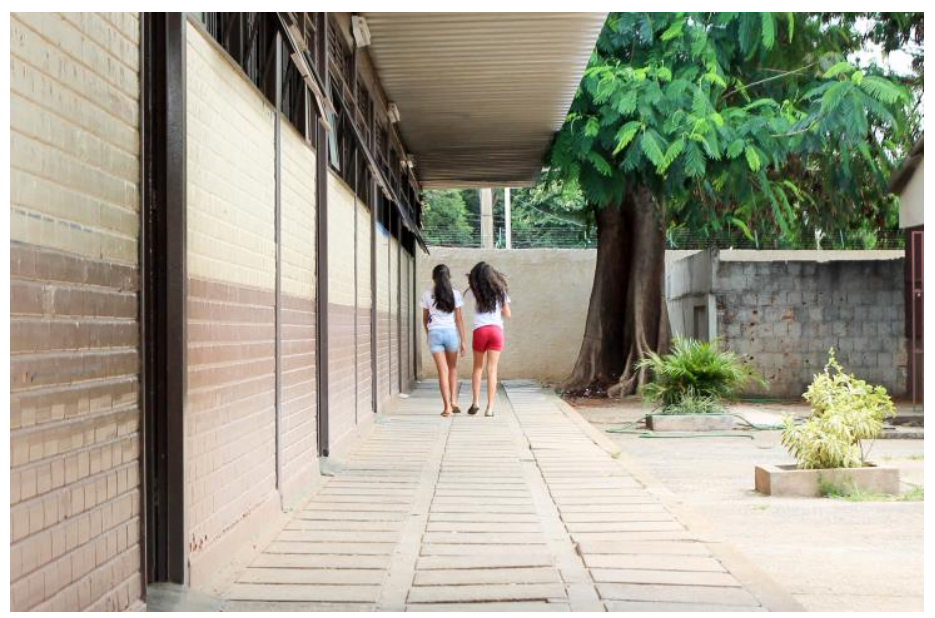

